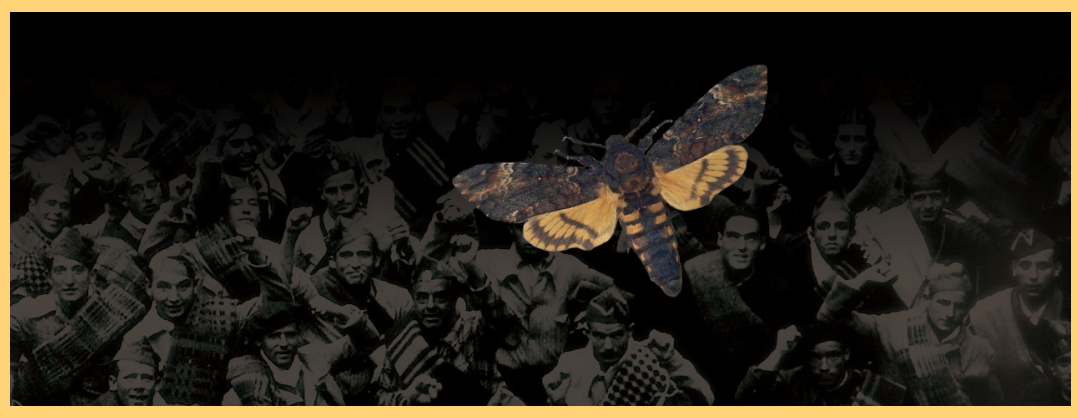

Mariposas de Madrid Los narradores italianos

y la guerra civil española

Luciano Curreri 

MARIPOSAS DE MADRID

Los narradores italianos y la guerra civil española 



\title{
MARIPOSAS DE MADRID \\ Los narradores italianos y la guerra civil española
}

\author{
Luciano Curreri \\ Traducción de Malena Manrique \\ y José Joaquin Blasco
}

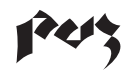

Prensas Universitarias de Zaragoza 


\section{FICHA CATALOGRÁFICA}

\section{CURRERI, Luciano}

Mariposas de Madrid : los narradores italianos y la guerra civil espańola / Luciano Curreri ; traducción de Malena Manrique y José Joaquín Blasco. — Zaragoza : Prensas Universitarias de Zaragoza, 2009

284 p. ; $22 \mathrm{~cm}$. - (Humanidades ; 73)

ISBN 978-84-92521-73-9

1. Novela italiana-S. XX. 2. Sciascia, Leonardo (1921-1989) Antimonio. 3. Espańa-Historia-1936-1939 (Guerra Civil). I. Manrique, Malena, tr. II. Blasco, José Joaquín, tr. III. Prensas Universitarias de Zaragoza. IV. Título. V. Serie: Humanidades (Prensas Universitarias de Zaragoza) ; 73

821.131.1-3«19»

821.131.1Sciascia, Leonardo7Antimonio.07

94(460)«1936/39»

Cualquier forma de reproducción, distribución, comunicación pública o transformación de esta obra solo puede ser realizada con la autorización de sus titulares, salvo excepción prevista por la ley. Diríjase a CEDRO (Centro Espańol de Derechos Reprográficos, www.cedro.org) si necesita fotocopiar o escanear algún fragmento de esta obra.

(C) Luciano Curreri

(C) De la presente edición, Prensas Universitarias de Zaragoza

$1 .^{a}$ edición, 2009

Edición original: Le farfalle di Madrid. Lantimonio, i narratori italiani e la guerra civile spagnola, Roma, Bulzoni Editore, 2007

Ilustración de la cubierta: José Luis Cano

Colección Humanidades, n. 73

Director de la colección: José Ángel Blesa Lalinde

Prensas Universitarias de Zaragoza. Edificio de Ciencias Geológicas, c/ Pedro Cerbuna, 12 50009 Zaragoza, Espańa. Tel.: 976761 330. Fax: 976761063

puz@unizar.es http://puz.unizar.es

Prensas Universitarias de Zaragoza es la editorial de la Universidad de Zaragoza, que edita e imprime libros desde su fundación en 1542.

Impreso en España

Imprime: INO Reproducciones, S. A.

D. L.: Z-1572-2009 
A mis padres, Antonio y Luisa, y a mis dos abuelos, Matteo Curreri (Grotte, 1903-Turin, 1984), peregrino antifascista por causa de su "preferiría no hacerlo"..., y Paolo Scalabrin (Quartiere, 1922-Rusia, ¿1942?), desaparecido en otra guerra, que quizá era la misma... 

Alguien insinuó que estaba a punto de estallar una bomba, como se había visto recientemente en una película sobre la revolución rusa.

- ¿Dura desde hace mucho la guerra, abuela? otras aún.

-No, hija mía. La de hoy es otra guerra. Y vendrán

Fabrizia Ramondino, Guerra di infanzia e di Spagna

[...] dirigiéndose ahora a Robert Jordan como si hablase a unos alumnos, casi dando una conferencia.

[...]

-Y además me gusta charlar. Es la única cosa civilizada que nos ha quedado. ¿Cómo podríamos distraernos, si no? ¿Acaso no te interesa lo que te digo, Inglés?

Ernest Hemingway, Por quién doblan las campanas 



\section{"DÁBAMOS VUELTAS EN TORNO A MADRID COMO LAS MARIPOSAS, DE NOCHE, EN TORNO A LA LLAMA». PREMISAS Y CONSECUENCIAS SCIASCIANAS}

1. Historia, filosofía, crítica social y compromiso político: aproximaciones a una ética del lenguaje en El antimonio (1960)

Titular y partir con una cita es un vicio. Pero citar a Leonardo Sciascia a propósito de la guerra civil espańola (1936-1939) se convierte en una virtud. Con El antimonio, largo relato que cierra la segunda edición de Los tíos de Sicilia (1960), Sciascia es uno de los pocos narradores italianos del siglo XX que ha recordado y compartido ese drama, a partir de su región y con un "yo narrador" en el que - lo dice con exactitud y firmeza Claude Ambroise - ${ }^{1}$ "a pesar de la refinada modelización narratológica», a la que recurriremos sumariamente en el epígrafe 4, "permanece el signo, y por tanto la concreta manifestación, de una ambivalencia en que ese "yo" se identifica, más o menos, con el autor de carne y hueso». ${ }^{2}$

1 Claude Ambroise, "Il libro nel libro», en La Sicilia, il suo cuore. Omaggio a Leonardo Sciascia (1992), 2. ${ }^{\text {a }}$ ed. a cargo de Maria Lucia Ferruzza, Fondazione L. Sciascia-Fondazione G. Whitaker, Palermo-Racalmuto, 1998, p. 40.

2 Además de subrayar la importancia y el papel del autor, más allá de sus diversas e inevitables muertes, nos parece que la fuerte sugerencia de Ambroise ha de ponerse en relación con aquella «oleada narratológica de los años setenta» que, paradójicamente, ha contribuido, según Carlo Alberto Madrignani, «a desmaterializar el objeto-novela sustra- 
Pero si «el yo narrador no debe ser identificado exclusivamente con la serie ex minero del azufre siciliano/veterano de guerra/futuro bedel», ${ }^{3}$ tampoco hay que buscar a Sicilia solo en la región natal de Sciascia, más o menos presente y ligada a la generación del escritor. Aun cuando esta sea representativa de las generaciones que no deben olvidar - a ellas parece dirigirse el ex minero siciliano al final de El antimonio - y tal vez también de «un presente que se resuelve en acción [...] vinculado a una idea de futuro incluso cercano». ${ }^{4}$

Sicilia, de todos modos, contiene los síntomas de la guerra, en sentido histórico, concreto, colectivo, cuando la Italia fascista hereda a los "pobres desocupados de las Dos Sicilias» y los emplea en las guerras de Etiopía, de España, y en «otra, acaso más grande». ${ }^{5}$ La misma Sicilia recoge luego, provisionalmente, las secuelas del conflicto pero no se presenta como punto de referencia. La región de Sciascia no es un destino, no puede acoger las consecuencias de la guerra sino solo hacer que circulen. Porque ha habido una guerra — todavía dura ("cosas tremendas que yo he vivido y que Espańa vivía») — ${ }^{6}$ y no puede resolverse en el horizonte siciliano del que se ha partido, dentro de una «abstracción, cómo llamarla, geográfico-climática».7

yéndolo a las dinámicas del contexto", es decir, a hacer de la narrativa en parte una entidad abstracta (ahistórica, afilosófica, apolítica), sin una auténtica colocación en el pasado ni en el presente, contextos amplios de una recepción dialéctica, de una historia de la crítica que, cuando ha dejado de ser historia (del pasado y del presente a la vez) para ser solo crítica (sobre todo, teoría crítica), ha caído en una crisis creciente. Cfr. la entrevista a Madrignani de Mariolina Bertini y Lidia De Federicis publicada en L'Indice, 9, 2005, p. 13.

3 Ambroise, "Il libro nel libro", cit.

4 Lionello Sozzi, Vivere nel presente. Un aspetto della visione del tempo nella cultura occidentale, Il Mulino, Bolonia, 2004, p. 12.

5 Leonardo Sciascia, El antimonio, en Los tíos de Sicilia, col. Coralli, Einaudi, Turín, 1960, 2. ${ }^{\text {a }}$ ed. (la 1. ${ }^{\mathrm{a}}$, sin El antimonio, apareció en la col. Gettoni, 1958; en 2005 Einaudi la reimprime en una «edición no venal reservada a clientes de venta a plazos». Citamos por la 8. a ed. de Nuovi Coralli, 1980 (la primera es de 1972), pp. 204 y 216. Cfr. Le edizioni Einaudi negli anni 1933-2003, col. Piccola Biblioteca Einaudi, Einaudi, Turín, 2003, p. 730 (ed. española en Tusquets, col. Fábula, Barcelona, 2001, trad. Alfredo Citraro). [N. de los T.: En esta cita y en las siguientes traducidas al español, las páginas remiten a la edición original.]

6 Sciascia, El antimonio, cit., p. 227.

7 Sciascia, «Il Gattopardo» (1959), en Pirandello e la Sicilia, Salvatore Sciascia Editore, Caltanissetta, 1961 y 1968, ahora en Opere 1984-1989, ed. Claude Ambroise, col. Classici, Bompiani, Milán, 1991, pero se cita por la col. Classici en rústica, 2002, p. 1161: «La Sicilia del Gattopardo tiene un vicio de abstracción, cómo llamarla, geográfico-climática». Para la evolución del juicio de Sciascia sobre el Gattopardo en el arco, al menos, de un ventenio, de 1959 a 1979, cfr. Manuela Bertone, Tomasi di Lampedusa, Palumbo, Palermo, 1995, pp. 99-100. 
Téngase en cuenta que esto no significa compartir la tesis de una «novela [...] sin tierra adentro e incluso sin tierra (en nombre del rechazo idealista a un relato siciliano, sardo, toscano o de otras regiones)", con que justamente ha polemizado Madrignani. ${ }^{8}$ Por lo demás, en palabras de este autor, podemos alejar la Sicilia sciasciana precisamente del "color local» y de "generosos escepticismos", ${ }^{9}$ y apartar El antimonio, en concreto, de $E l$ gatopardo, cronológicamente cercano (1958), de Giuseppe Tomasi di Lampedusa.

En ese sentido, El antimonio, de 1960, parece más bien la respuesta novelesca de Sciascia a El gatopardo tras su respuesta crítica de $1959^{10}$ y antes de El archivo de Egipto (1963), que, como se sabe, es el "antigatopardo», según Giancarlo Vigorelli. ${ }^{11}$ Es más, quizá como experimento de «novela histórica» —o bien, según el mismo Sciascia, como «obra [...] en que los acontecimientos representados son parte de una "realidad historificada", es decir conocida y puesta, por su valor y sus consecuencias, en relación con el presente»- ${ }^{12}$, El antimonio parece convertirse en la versión sciasciana de Ha habido una guerra (1945), que abre la tercera sección, «Políticas», de Sentido y sinsentido (1948) de Maurice MerleauPonty y del que es útil citar alguna línea para el desarrollo de nuestra argumentación:

Hemos llegado a asumir y considerar como nuestros no solo las intenciones y el sentido que nuestros actos tienen para nosotros, sino tam-

8 Cfr. la entrevista a Madrignani de Bertini-De Federicis en L'Indice, cit., p. 13.

9 Madrignani, "Cassola e altri "buoni maestri"”, en L'ultimo Cassola. Letteratura e pacifismo, Editori Riuniti, Roma, 1991, p. 97, que concluye: «la línea gatopardesca es la quintaesencia de este sicilianismo autoindulgente».

10 Cfr. Sciascia, «El Gattopardo» (1959), cit., pero también Mario Alicata, «Il principe di Lampedusa e il Risorgimento italiano» (1959), en Scritti letterari, introd. Natalino Sapegno, Il Saggiatore, Milán, 1968, pp. 337-353.

11 En Tempo, 26 de febrero de 1963, citado en Ambroise, Invito alla lettura di Leonardo Sciascia, Mursia, Milán, 1974 y 1983, p. 219.

12 Sciascia, "Verga e il Risorgimento» (1960), en Pirandello e la Sicilia, cit., luego en Opere 1984-1989, cit., p. 1147. Nunzio Zago —que da la razón a Sciascia cuando este reconoce que en el Gatopardo el presente se hace pasado, «se somete, por así decir, a una operación de envejecimiento"— dice que "el problema es muy distinto: el escritor [Tomasi di Lampedusa] se sitúa más allá de la noción lukácsiana de realismo y, por tanto, el modelo canónico, decimonónico, de "novela histórica" le viene estrecho, es ya inadecuado para él». Cfr. Nunzio Zago, I Gattopardi e le Iene. Il messaggio inattuale di Tomasi di Lampedusa, Sellerio, Palermo, 1983, p. 36. 
bién las consecuencias externas de tales actos, y el sentido que asumen en cierto contexto histórico. ${ }^{13}$

En "cierto contexto histórico», como el representado por la guerra civil española, el doble cariz del narrador sciasciano - hacerse íntimamente partícipe del conflicto y, al mismo tiempo, compartir sus "consecuencias externas»- está en el origen de uno de los relatos más logrados y complejos de la narrativa italiana del siglo Xx. Contexto histórico que no es un simple escenario del pasado — «fondo o atmósfera»—, ${ }^{14} \mathrm{y}$ su abordaje debe verificar en el presente esos «valores de libertad, autenticidad, transparencia" que de otro modo serían "puramente nominales, sin infraestructura social y económica que los volviera realidad»: «El instrumento que permita verificar los valores de un humanismo que no quiera quedarse en una abstracción, sino que sea fuerza transformadora de la situación humana, es la política». Y "la cuestión política se plantea a partir del horizonte del existencialismo, centrado en el análisis del arraigo de la subjetividad en el mundo, y abierto a los motivos de la intersubjetividad, de la sociedad, de la historia». ${ }^{15}$

Los «motivos de la intersubjetividad, de la sociedad, de la historia» y el «análisis del arraigo de la subjetividad en el mundo» ponen en contacto, en el relato de Sciascia, los síntomas (entre ellos, «la política [que] nos parecía impensable [...] antes de la guerra», siempre según MerleauPonty) ${ }^{16}$ y las secuelas de la guerra. Secuelas que, en el año de la primera edición de Los tios de Sicilia (1958), recupera La condición humana (1958), «el libro de la resistencia y de la reconstrucción» de Hannah Arendt. Las recupera precisamente para la política, después de «la paradoja epistemo-

13 Merleau-Ponty, «C’è stata la guerra» (1945), en Senso e non senso (1948), introd. Enzo Paci, Il Saggiatore, Milán, 1962, p. 175 (ed. española: Sentido y sinsentido, trad. Narcís Comadira, Península, Barcelona, 2000). Para la toma de posición de Merleau-Ponty en relación con la guerra espańola, cfr. Guy Hermet, La guerre d'Espagne, col. Points-Histoire, Seuil, París, 1989, p. 239: «En mayo [1937] sigue a este primer manifiesto un segundo texto contra los bombardeos de Durango y Guernica, al que se asocian por vez primera hombres como François Mauriac, Charles Le Bras, Gabriel Marcel, Merleau-Ponty, Claude Bourdet y Georges Bidault».

14 Sciascia, "Verga e il Risorgimento» (1960), cit., p. 1147.

15 Ornella Pompeo Faracovi, "Filosofia e politica», en Giovanni Invitto (ed.), Merleau-Ponty. Esistenza, Filosofia, Politica, Guida, Nápoles, 1982, pp. 176-177 y 175.

16 Merleau-Ponty, "C’è stata la guerra», cit., p. 175. 
lógica sobre la que gira Los orígenes del totalitarismo (1951)». ${ }^{17}$ Síntomas y secuelas serán luego colocados (y, dialécticamente, dinamizados) dentro de un «regreso», que no es solo el destino del veterano de guerra, del soldado mutilado, sino también un escenario de la subjetividad que en su elemento más íntimo, individual, recibe y amplifica el dato histórico, colectivo, hasta soldar «estos seres singulares, cada uno de los cuales es en sí mismo un mundo", ${ }^{18}$ a la human condition.

La mutilación, entonces, es ya «la fuerza transformadora de la situación humana»: la mano perdida es el cuerpo social perdido, del que nos desprendemos, como veremos, incluso desde conocidos modelos de crítica social y compromiso político, y a la vez es el nuevo cuerpo social que se perfila en el final abierto del relato: "Quiero ver cosas nuevas». ${ }^{19}$ Es más, en el par síntomas-secuelas de la guerra civil española — que contempla un doble iter del protagonista: "Sicilia-España-Sicilia-otro lugar» (itálico, desde luego, pero con «España en el corazón»)—, ${ }^{20}$ El antimonio se esfuerza complementariamente en experimentar las formas de ejercicio del poder y de dominio de sí mismo gracias, precisamente, a una subjetividad expuesta que, casi como en «una "iniciación del sujeto o, mejor, una "iniciación al sujeto" ", ${ }^{21}$ no está nunca desligada de "todos los demás hombres» y de un «ejercicio ético» que no es, ciertamente, «la decisión carte-

17 Cfr. Paul Ricoeur, prefacio (1983) a la ed. francesa de Hannah Arendt, Condition de l’homme moderne, Calmann-Lévy, París, 1961 y 1983, luego en col. Agora, Presses Pocket, París, 1988, pp. 14 y 12 (La condición humana, trad. Ramón Gil Novales, Paidós, Barcelona, 2005). Algunas pistas de lectura de Ricoeur relativas a los fertilísimos ańos cincuenta quedan confirmadas en Arendt, Denktagebuch (1950-1973), Piper Verlag, Múnich, 2002, cuya edición en francés es reciente: Journal de pensée (1950-1973), Seuil, París, 2005, vol. I, pp. 45-512, y vol. II, pp. 667-803. Este diario de trabajo nos ayuda a entender mejor la articulación entre Los orígenes del totalitarismo — con los borradores corregidos en 1951, en los orígenes del journal - y La condición humana (1958), entre el lado crítico y el lado constructivo de la obra arendtiana, especialmente en relación con el tema de la política y su posibilidad, su humanidad, su fragilidad, y con la responsabilidad y la salvaguardia de un mundo común, plural.

18 Merleau-Ponty, «C’è stata la guerra», cit., p. 175.

19 Sciascia, El antimonio, cit., p. 230.

20 Sciascia, Ore di Spagna, introd. Natale Tedesco, fotos de Ferdinando Scianna, Pungitopo, Marina di Patti (Messina), 1988, luego en Bompiani, Milán, 2000, p. 29 (Horas de España, trad. Carlos Manzano, fotos de Scianna, Tusquets, Barcelona, 1990).

21 Carlo Sini, Etica della scrittura, Il Saggiatore, Milán, 1992, p. 215, citado por Pier Aldo Rovatti, Abitare la distanza. Per un'etica del linguaggio, Feltrinelli, Milán, 1994, pp. 31-33. 
siana de un sujeto filosófico que dirige sobre sí mismo, en condiciones neutras y óptimas para el experimento, un rayo de luz intelectual»: ${ }^{22}$

He ido a España sabiendo apenas leer y escribir [...] y he vuelto pudiendo leer, creo, las cosas más duras que un hombre puede pensar y escribir. Sé por qué el fascismo no muere, y todas las cosas que con su muerte deberían morir estoy seguro de conocerlas, y lo que en mí y en todos los demás hombres debería morir para que el fascismo muriera para siempre. ${ }^{23}$

Atención. No se trata del "'microfascismo" de la vida cotidiana» sobre el que se centra Michel Foucault, quien, para Michael Walzer, «tiene poco que decir sobre la política autoritaria y totalitaria» y "parece no creer en principio en la existencia de un dictador o de un partido o de un estado». ${ }^{24}$ El antimonio, a este propósito, es muy claro, como veremos. ${ }^{25}$

22 Ib., p. 31. Cfr. de nuevo Madrignani, L'ultimo Cassola, cit., p. XV: «Los filósofos no aceptan lecciones de los hechos. Las Ideas tienen una superioridad espontánea que espera ser "verificada" en los acontecimientos del bajo mundo. Solo los hombres comunes, tan amados por Cassola [y también por Sciascia, según Madrignani, que no por casualidad lo sitúa, repetimos, entre los «buenos maestros» que constituyen el horizonte literario y civil de Cassola; ib., pp. 85-105], que no se atienen a la altura del Pensamiento Absoluto, creen que de la experiencia puede nacer alguna forma de saber e iluminación para la praxis».

23 Sciascia, El antimonio, cit., p. 204.

24 Michael Walzer, «La politica solitaria di Michel Foucault», en L'intellettuale militante. Critica sociale e impegno politico nel Novecento (1988), introd. Saverio Vertone, Il Mulino, Bolonia, 1991, p. 260.

25 Tampoco se trata del «fascismo eterno» del que habla en distintos lugares, desde 1995, Umberto Eco, tal vez con una (más o menos) explícita lectura de un Ventenio superficial y, sobre todo, con «interpretación ahistórica y transpolítica», como justamente notaba Alessandro Campi en 1996. El año siguiente, en cambio, para Antonio Tabucchi el ensayo de Eco es «verdaderamente estimable», pues «las etiquetas cambian, la sustancia queda». Cfr. Umberto Eco, "Totalitarismo "fuzzy" e Ur-Fascismo", La Rivista dei Libri, 7-8, 1995, y con el título "Fascismo eterno» en Cinque scritti morali, Bompiani, Milán, 1997, pp. 25-48, breve colección de artículos cuyos temas retoma en parte en el más imponente (y más político) $A$ passo di gambero. Guerre calde e populismo mediatico, Bompiani, Milán, 2006 (A paso de cangrejo, trad. María Pons, Debate, Barcelona, 2007). Para la «interpretación ahistórica y transpolítica» de Eco, cfr. Campi, "Che cos'è Alleanza Nazionale», Trasgressioni, 21, 1996, y ahora en Il nero e il grigio. Fascismo, destra e dintorni, Ideazione Editrice, Roma, 2004, pp. 455-499; en particular, pp. 461 y 491. Sobre esta colección de artículos, a menudo aguda, que nos permite seguir la parábola del fascismo desde su fundación a la República social de Salò y hasta el partido Alianza Nacional, cfr. el juicio positivo de Bruno Bongiovanni, «Un’associazione a delinquere. Il fascismo tra parentesi e totalitarismo", L'Indice, 3, 2005, p. 7. Por último, Antonio Tabucchi, La gastrite di Platone, Sellerio, Palermo, 1998, p. 58 (La gastritis de Platón, trad. Carlos Gumpert, Anagrama, Barcelona, 1999), panfleto donde otra intervención de Eco es el polémico punto de partida del autor de Sostiene Pereira (1994), particular novela de formación de un héroe intelectual âgé, sobre el que remito al capítulo 3. 
Para Sciascia, hacer transitar por España y su guerra civil la mencionada iniciación no significa que escape fácilmente al punto de vista del pobre y anónimo desempleado de las «Dos Sicilias», sino que más bien trata de superar el continuo cortocircuito entre regresión y emancipación $\mathrm{o}$, si se quiere, entre mimetismo, evidente a nivel estilístico, ${ }^{26}$ y soliloquio de impronta autoral.

La literaria (y, en parte, cinematográfica) «mezcla de lenguajes y códigos no solo heterogéneos, sino incluso contradictorios, esto es, cultísimos y plebeyos» —en un nivel ético, pero no solo, como ha puesto en evidencia Antonio di Grado-, no tiene por fuerza que hacer desaparecer al Sciascia intelectual de la historia de la recepción, confinándolo por entero - juicio anticipador, quizás en parte legítimo pero inválido, desde luego, si se hace una lectura retroactiva - en el archivo más descomprometido de esa "posmoderna» y/o "vasta "clase media cultural" que funde alta cultura y cultura de masas», según los avatares del compromiso identificados y recogidos a lo largo de los años ochenta y noventa por Alfonso Berardinelli en El esteta y el politico (1986) y El héroe que piensa (1997). ${ }^{27}$

Por el contrario, Leonardo Sciascia parece imponerse en algunas de sus obras (las primeras, sobre todo) la exigencia de apartarse de sí mismo, como sugiere Giuseppe Traina en sus últimos artículos sciascianos. A la altura de El antimonio, esta exigencia se apoya en un esfuerzo bendecido por el éxito, porque se concreta, como veremos con detalle, en una instancia plural que difumina y aleja el narcisismo del artista. Casi podríamos decir - recuperando a Sciascia para el presente, desde este punto de vista, al menos desde los ańos sesenta hasta los noventa, década de intensos balances para nuestro autor y el siglo XX- que el escritor siciliano se impone aparentemente la «exigencia de apartarse de nosotros, de tomarse un tiempo y un espacio respecto a nuestro narcisismo", y se impone incluso el reconocimiento de una ilusión: "La ilusión [...] de que el sujeto hablante desaparece: no como enunciador de la frase sino porque se ha

26 Enrico Testa, Lo stile semplice. Discorso e romanzo, Einaudi, Turín, 1997, p. 274.

27 Antonio di Grado, «Sciascia, il cinema e (fra l'altro) l'Europa: (bianco e) nero su nero", en "Quale in lui stesso alfine l'eternità lo muta». Per Sciascia, dieci anni dopo, Salvatore Sciascia Editore/Fondazione L. Sciascia, Caltanissetta-Roma, 1999, p. 68. Cfr. Alfonso Berardinelli, L'esteta e il politico. Sulla nuova piccola borghesia, Einaudi, Turín, 1986, y L'eroe che pensa. Disavventure dell'impegno, Einaudi, Turín, 1997. 
quedado a vivir en ella definitivamente». ${ }^{28}$ En el seno de esta ilusión, el punto de vista del pobre y anónimo desempleado de las «Dos Sicilias» pasa a ser parte integrante, importante, de un ejercicio ético, de una ética del lenguaje. Lenguaje que no extravía ni engaña al pobre y anónimo desempleado, al soldado mutilado, al futuro bedel, que poco a poco tienden a habitarlo como figuras distantes. ${ }^{29}$

Apartarse de uno mismo, de nosotros mismos, en el doble $-\mathrm{y}$ progresivo- sentido indicado, no significa ser despegado. Contra la imagen

28 Rovatti, Abitare la distanza. Per un'etica del linguaggio, cit., pp. 23 y 24.

29 Tampoco los entrega a "la más tremenda intolerancia», como a fin de cuentas querría Eco, quien gusta de identificar tal intolerancia con «la de los pobres, primeras víctimas de la diferencia», y la confía a escritos que se pretenden "morales» y en cambio parecen responder —en sus genéricos y no compartibles axiomas - a ese difundido «engagement al revés» en virtud del cual — según Adriano Sofri, citado por Tabucchi en La gastritis de Platón- «algunos intelectuales, contemporáneos nuestros, comprometen gallardamente la propia firma para atacar a los pobres, los débiles, los mal vistos». Dice Eco: «No hay racismo entre los ricos. Los ricos, si acaso, han producido las doctrinas racistas; pero los pobres producen su práctica, mucho más peligrosa». Claro, que si atenuamos el uso de dos categorías tan genéricas y hacemos de ellas, más sutilmente, una cuestión de formación o de malestar social, como parece hacer Eco en otro momento ("A toutes fins utiles», en Jean-Claude Carrière, Jean Delumeau, Umberto Eco, Stephen Jay Gould, Entretiens sur la fin de temps, realizadas por Catherine David, Frédéric Lenoir y Jean-Phillippe de Tonnac, Fayard, París, 1998, pp. 235-295, en particular pp. 262-264), las coordenadas de Eco pueden al menos tornarse útiles, no tanto para el soldado mutilado cuanto para los viejos y el secretario fascista, que, como extremos de la comunidad rural, oscilan entre la ignorancia y la propaganda al final de El antimonio. Véase Umberto Eco, «Le migrazioni, la tolleranza e l'intollerabile», en Cinque scritti morali, cit., pp. 93-113, sobre todo p. 106. Para las páginas de Sofri, dos cartas a Tabucchi publicadas en L'Espresso, 16 de octubre de 1997 y 29 de enero de 1998; cfr. Tabucchi, La gastrite de Platone, cit., pp. 63 y 71: «Esta Italia, que no se concibe pidiendo perdón pero sabe exigirlo hasta el infinito y ritualmente a los caídos y a los débiles». Por los mismos años, el último Bobbio - tan cercano al primero, el de Politica e cultura, Einaudi, Turín, 1955 y 2005, Nuova Edizione, introd. Franco Sbarberi, además de los ensayos (1953-1992) de Il dubbio e la scelta. Intellettuali e potere nella società contemporanea, Carocci, Roma, 1993 - escribía en las páginas iniciales de su Autobiografía, ed. Alberto Papuzzi, Laterza, Roma-Bari, 1997 y 1999, p. 9 (Autobiografia, trad. Esther Benítez, Taurus, Madrid, 1998): "Hemos sido educados para considerar a todos los hombres iguales, y a pensar que no hay diferencia entre el culto y el inculto, el rico y el que no lo es. He recordado esta educación a un estilo de vida democrático en Derecha e izquierda, donde confieso haberme sentido siempre a disgusto ante el espectáculo de las diferencias entre ricos y pobres, entre quienes están arriba y quienes están abajo en la escala social, mientras que el populismo fascista trataba de regimentar a los italianos en una organización social que cristalizase las desigualdades». Cfr. Norberto Bobbio, Destra e sinistra. Ragioni e significati di una distinzione politica, Donzelli, Roma, 1994 y, sobre todo, la 2. a ed. de 1995 (Derecha e izquierda. Razones y significados de una distinción politica, trad. Alessandra Picone, Taurus, Madrid, 1997). 
de un Sciascia despegado y tal vez pagado de ese «extraño y revelador despego» que se achacaba a Giuseppe Tomasi di Lampedusa ${ }^{30}$ (luego se entendió, con un juicio menos categórico), ${ }^{31}$ e incluso contra la imagen de un Sciascia indignado y escéptico, entre la ironía y la prudencia, semejante en esto a Eco, según un balance crítico finisecular sobre el que volveremos, ${ }^{32}$ añadiría enseguida — con Paolo Manganaro, en su artículo de 1991 dedicado a «Sciascia y España»— que en los textos sciascianos «no hay, al final, naufragio con espectadores. Ninguna isla generacional [o de clase]»:

El gran privilegio de este escritor, que nos ha condenado a comprenderlo, es que nunca se ha quedado fuera, como un marionetista, manejando los hilos de sus personajes. Aun cuando evidentemente se trate de una ficción, como en el caso del minero de El antimonio, una ficción intelectualizada con un personaje al que Sciascia atribuye gusto, sensibilidad y pensamientos que no podían corresponderle, nuestro escritor se descubre enseguida, asumiendo la responsabilidad de lo que la sombra o eidolon de un minero del azufre podría decir. $^{33}$

Uniendo las certeras observaciones de Manganaro con las que Rovatti dedica a nuestros intentos — «nosotros, habitantes de esta tierra, hombres cualesquiera del hoy»- de Habitar la distancia (1994), podríamos decir que no quedarse fuera significa también tener «el pudor de reconocerse dentro del juego y, en consecuencia, jugársela»: «el pudor como distancia» no nos habla "de la vida apartada del sabio que se aleja de las cosas del mundo", ni de «excluirse, como si el sujeto, [...] que no se agota en el sujeto gramatical, tampoco en una dispersión de "yoes", tuviese la posibilidad de apartarse o estar ya fuera, asumiendo para sí una de las figuras del tradicional espectro filosófico que va del espectador desinteresado al "funcionario de la humanidad" ". ${ }^{34}$

Asumir la responsabilidad de lo que la sombra o eidolon de un minero del azufre podría decir significa a la vez el rechazo — así lo sugiere Madrignani a propósito del «mejor Sciascia, que ha dejado un vacío que no vemos

30 Sciascia, «Il Gattopardo», cit., p. 1169.

31 Cfr. Bertone, Tomasi di Lampedusa, cit., pp. 99-100.

32 Véase el epígrafe 2 de este capítulo.

33 Paolo Manganaro, «Sciascia e la Spagna», en Zino Pecoraro y Enzo Scrivano (eds.), Omaggio a Leonardo Sciascia, actas del congreso internacional de Agrigento, 6-8 de abril de 1990, Agrigento, 1991, pp. 192-193.

34 Rovatti, Abitare la distanza, cit., pp. 22, 12 y 18. 
cómo puede llenarse»— «de éxtasis paisajísticos, de color local, de momentos pasionales, de sicologismos "metafísicos", de clarividentes escepticismos». ${ }^{35}$ Prueba de ello es el lema que abre El antimonio (1960), traída de Conquistador (1932), de Archibald MacLeish, quien abrazó la causa republicana durante la guerra civil.

And the Cardinal dying and Sicily over the ears-Trouble enough without new lands to be conquered... We signed on and we sailed by the first tide... ${ }^{36}$

Sin olvidar que Sciascia crea un mito de la sicilianidad que va mucho más allá (o más acá) de la realidad en que efectivamente vivimos y que, a veces, está dispuesto incluso a contradecir tal visión mitificadora, siempre podríamos señalar — con Paolo Manganaro- que a partir de «una especie de "ontología regional"”, ese exergo genera, entre Sicilia y España, una serie de "construcciones culturales impuras, que no debían sostenerse en un solo elemento sino que, como sucede en una estructura de ejes transversales, se equilibrasen mediante el entrecruzamiento y la presencia conjunta de diversos elementos». ${ }^{37}$

Tales construcciones no se apoyan únicamente en un abordaje sincrónico de diversos elementos geográficos, físicos, dentro del tiempo determinado y en cierto modo finito de la ficción, esto es, la segunda mitad de los años treinta, sino que los incorporan diacrónicamente y extienden sus premisas y consecuencias históricas a generaciones que no deben olvidar: los síntomas de la guerra de Sicilia-España se funden así con las secuelas de la Guerra de España-Sicilia. La estratagema del «regreso" a casa, al pueblo, hace tiempo que ya no es factible. No hay Edén, nunca lo ha habido, y la novela, la novela italiana moderna que arranca normalmente de Alessandro Manzoni, se queda sin idilio. ${ }^{38}$

35 Madrignani, "Cassola e altri "buoni maestri”", cit., pp. 96 y 97.

36 «Y el cardenal moribundo y Sicilia más allá de las espigas - ya era bastante arduo no tener nuevas tierras que conquistar... Nos enrolamos y zarpamos con la primera marea...». Cfr. Sciascia, L'antimonio, cit., p. 165.

37 Manganaro, «Sciascia e la Spagna», cit., p. 193.

$38 \mathrm{Al}$ problema del idilio en Los novios ha dado «respuesta decisiva» Ezio Raimondi, Il romanzo senza idillio. Saggio sui "Promessi sposi», Einaudi, Turín, 1974. Cfr. también Guido Baldi, "I promessi sposi»: progetto di società e mito, Mursia, Milán, 1985, pp. 10-12, $121-133$ y $185-196$. 
Justamente quizás como lector de Manzoni, como escritor siciliano y heredero de un reto histórico y novelesco del siglo XIX, Sciascia niega igualmente ese "detalle del "final feliz"». Este detalle — que, podríamos sugerir, con Yosef Hayim Yerushalmi, para el historiador (manzoniano) es patrimonio de Dios y para la memoria (sciasciana) tiende en cambio a presentarse como divinidad, autoridad, contra la que hay que rebelarse -39 constituye la "clave para entender Los novios en sus límites y en su grandeza", además de la manifestación del «hombre clásico» y del "gran señor», o sea, de la «superioridad» y la consiguiente "ironía» de quien — dice Sciascia, citando El gatopardo - «elimina las siempre desagradables manifestaciones de buena parte de la condición humana y ejerce una suerte de aprovechable altruismo». ${ }^{40}$

En definitiva, no existe Edén ni «final feliz». Final feliz acaso introducido, servido por un marqués manzoniano o por uno de esos ricos sicilianos que - con el coro del pueblo todo, de la sociedad del pueblo, pobre y rica - en las páginas finales de El antimonio dicen al protagonista: «Has hecho dinero, ahora puedes vivir tranquilo». ${ }^{41}$ De manera que el regreso, como veremos, implica una partida, un irse "fuera de Sicilia», final abierto que circularmente recupera y engloba el exergo. ${ }^{42}$

Pero nótese enseguida que de ese modo Sciascia quiere sugerir al lector un doble camino crítico para el héroe, precisamente dentro del tiempo de las generaciones que no deben olvidar. Por eso también el héroe carece de nombre y se inscribe, sin dificultad, en una idea de memoria colectiva - halbwachsiana - y en una fenomenología de la memoria - husserliana y ricoeuriana- que supera el impasse de quién recuerda a favor, en favor de qué se recuerda e incluso qué se trata de recordar (que es, a la postre, la "pregunta de un recuerdo»). ${ }^{43}$

39 Yerusahlmi, «Riflessioni sull'oblio», en Yosef Hayim Yerushalmi, Nicole Loraux, Hans Mommsen, Jean-Claude Milner, Gianni Vattimo, Usi dell'oblio (1988), Pratiche, Parma, 1990, p. 21.

40 Sciascia, «Il Gattopardo», cit., pp. 1163, 1169 y 1162.

41 Sciascia, L'antimonio, cit., p. 228.

42 Ib., p. 230.

43 Paul Ricoeur, La Mémoire, l'histoire, l'oubli, Seuil, París, 2000, pp. 3-4 y 112-163 (La memoria, la historia, el olvido, trad. Agustín Neira, Trotta, Madrid, 2003). Sobre la "gran propuesta» de Ricoeur, en relación con la problemática histórica, que gravita en este libro, cfr. Giuseppe Ricuperati, Apologia di un mestiere difficile. Problemi, insegnamenti e responsabilità della storia, Laterza, Roma-Bari, 2005, pp. 143-160. 
Claro que Sciascia, autor y crítico —además de héroe intelectual, categoría brombertiana de 1960 —, asume la responsabilidad incluso nominal de lo que la sombra o eidolon de un minero del azufre podría decir, pero el anonimato, el ser anónimo de este, debe también y sobre todo pensar, decir, escribir y servir a una exigencia colectiva: en la guerra como en la paz, o bien en esa paz que (todavía) es guerra. El nuevo soldado desconocido, que no "duerme contento», no está bautizado y por ello sobrevive, huyendo también de la huera retórica del monumento a los caídos que - tal como sugiere Merleau-Ponty en Ha habido una guerra_ ${ }^{4}$ transforma a las víctimas en héroes, en falsos héroes.

En principio, con un impulso platónico, el camino crítico del héroe empieza cuando deja el pueblo - es fácilmente imaginable, a estos efectos, una caverna oscura, resumen de fuegos y sombras en la mina, ${ }^{45}$ en la azufrera del antimonio-y parece hallar en España la iluminación de la Verdad, al punto de que cuando vuelve le «parece poder leer las cosas más duras que un hombre puede pensar y escribir». Esta nueva capacidad propicia su crítica del pueblo y sus habitantes, desde sus amigos hasta sus familiares, desde los viejos al secretario fascista. Y a la crítica, como es sabido, cierta autoridad. Pero la autoridad no caracteriza ciertamente al héroe, que no resulta "agigantado" (sino más bien «reducido») ni tiene "posición de autoridad» (parece encarnar, en sentido casi arendtiano, la trabajosa desaparición de la autoridad, cuya ausencia de la época moderna los partidarios del totalitarismo han explotado hábilmente). ${ }^{46}$

44 Merleau-Ponty, "C’è stata la guerra», cit., p. 169. Cfr. además Victor Brombert, The intellectual hero. Studies in the french novel (1880-1955), University of Chicago Press, Chicago, 1960.

45 Sobre la «alegoría platónica de la caverna», que será recurrente para nosotros, y sobre el exilio perpetuo derivado del «tener que ver con las sombras, nuestro sino según Platón", cfr. el sugestivo iter literario, pictórico y cinematográfico de Max Milner, L'Envers du visible. Essai sur l'ombre, Seuil, París, 2005, pp. 11-19, 391-411 y 431-437.

46 Maurizio Bettini, «Alle soglie dell'autorità», en Bruce Lincoln, L'autorità. Costruzione e corrosione (1994), Einaudi, Turín, 2000, pp. XXVI-XXIX, XX y XXXI. De este volumen véase, para nuestros fines, el interesante apéndice dedicado a "Gli intellettuali e la guerra fredda. Alcune discussioni sull'autorità negli anni Cinquanta»y, en particular, la famosa intervención de Hannah Arendt What was Authority? - luego en Between past and future: six exercises in political thought (1961) - en un congreso de 1956 sobre la autoridad "celebrado tras la caída de McCarthy y los primeros pasos de Kruschov hacia la desestalinización»; ib., p. 144. Cfr. Arendt, Tra passato e futuro, Garzanti, Milán, 1991 (Entre el pasado y el futuro: ocho ejercicios sobre la reflexión política, trad. Ana Poljak, Península, Barcelona, 2003). 
En esta fase, sin embargo, el personaje sciasciano nos acerca al «tipo camusiano de rebelde», ${ }^{47}$ que no se sienta en un estrado judicial como tantos filósofos —acaso "nostálgicos», y no es el caso de Arendt—, sino que se alinea con los "valores medios" y la "común existencia de la historia y del hombre, de la vida cotidiana iluminada del mejor modo posible, de la obstinada lucha contra la propia degradación y la de los demás». ${ }^{48}$ También en Sciascia — como en Camus, a quien le acerca «una prosa [...] a veces demasiado elevada, demasiado "noble" para acoger los valores medios»— «viene antes la lucha contra la propia degradación y luego, por

47 M. Walzer, «La guerra d'Algeria d'Albert Camus», en L'intellettuale militante, cit., p. 193.

48 Ib., pp. 185 y 192, que cita a Camus, L'artista e il suo tempo, "conferencia pronunciada en diversos lugares de Italia entre el 26 y el 30 de noviembre de 1955, un extracto de la cual ha sido publicado en la revista Il Ponte, XI, 1 (enero 1955), pp. 55-59»; ib., p. 195. Cfr. también la «anómala» entrevista homónima de 1953, traducida y recogida en la primera sección, "La pasión de la rebeldía», de Camus, La rivolta libertaria, pról. Goffredo Fofi, ed. Alessandro Bresolin, Elèuthera, Milán, 1998, pp. 73-76. En relacion con Sciascia, véase Ambroise, "Sciascia e la rivolta», en el denso volumen Titus Heydenreich (ed.), La responsabilità dell'intellettuale in Europa all'epoca di Leonardo Sciascia, actas del congreso de Pommersfelden, 6-10 de octubre de 1999, Universidad de Erlangen-Núremberg, Erlangen, 2001, pp. 165-186. En concreto, sobre la 2. a ed. de Los tíos de Sicilia - que Ambroise sitúa, frente a sus indicaciones anteriores del año 1960 (en la monografía editada en Mursia y en la cronología de obras de Sciascia para Bompiani), en 1961, subrayando el dato dos veces (pp. 168 y 171) pero sin ofrecer pruebas- y sobre El antimonio léanse las pp. 168-173 y 175-176, donde a partir de El hombre rebelde (1951) y sus primeras frases (“¿Qué es un hombre rebelde? Un hombre que dice no») se enfatiza que "para el héroe/antihéroe del relato, la experiencia de España es un apprentissage, el aprendizaje de decir no, de la rebeldía por consiguiente» y, en relación con el vínculo entre personaje y autor del que se hablaba al principio del capítulo, "para un análisis sobre el significado de El antimonio, no ofrece gran interés afirmar formalmente que el sujeto del enunciado y el de la enunciación son un solo personaje, si no se sobreentiende, a la vez, la existencia de una singular relación entre autor y personaje y no se subraya una relación entre el personaje y la decisión de escribir: escribir de la Guerra de España», porque "el texto es experiencia de España, la registrada por el personaje, y va más allá de su toma de conciencia inmediata» $\mathrm{y}$ "la eleccion de escribir permite afirmar la solidaridad con los revolucionarios pero, sobre todo, no querer abandonar la conciencia de la revolución» (p. 172). Trasladándose luego a la altura de Cándido, o un sueño siciliano (1977), cuando Sciascia «es socialmente reconocido como un gran escritor, como hombre público", Ambroise repite que "afirmar una relación entre el personaje y el autor de un relato, por la cual el personaje es también, para el escritor, un modo de situarse, no significa caer en el biografismo" y "saltar de Los tíos de Sicilia a Cándido [y más allá, hasta El caballero y la muerte y Una historia sencilla] permite trazar una perspectiva global bajo el signo de la rebeldía» (p. 175). Cfr. en fin Albert Camus, L'Homme révolté, Gallimard, París, 1951, y Folio-Essais, 1991, p. 27 (El hombre rebelde, trad. Josep Escué, Alianza, Madrid, 2005). 
extensión, contra la de los demás [...], el honor empieza por la lealtad a uno mismo, no por el compromiso ideológico» ${ }^{49}$ (cuya falta de prioridad, que no es una "no elección», no se traduce por fuerza en una ausencia).

Un fragmento, que pronto reproduciremos más ampliamente, marca esta postura intelectual del rebelde y del héroe, a dos páginas del final del relato:

Pero cuando uno vuelve de una guerra como la de España, con la certeza de que su casa arderá en el mismo fuego, no consigue hacer memoria de su experiencia y recuperar el sueño de costumbre. Quiere, por el contrario, que los demás estén despiertos, que también ellos sepan. ${ }^{50}$

En ese sentido, el cruce de dos instancias diferentes pero complementarias, no separadas sino dialécticamente conectadas, como son el mito y la actualidad, tal vez incluso el presente estático y el presente resuelto en acción, ${ }^{51}$ cruce contemplable en la caverna platónica y en las palabras camusianas relativas a la lucha contra la degradación, parece constituir el origen de El antimonio, en su primera y sobre todo en su última parte, donde aflora ese héroe que lucha denodadamente por salvar a los otros de la degradación. Obsérvese que «la denodada lucha contra la propia degradación y la de los demás» está en el centro de una conferencia de Camus, "El artista y su tiempo», ofrecida en diversos lugares de Italia y parcialmente publicada en 1955 en Il Ponte, ${ }^{52}$ revista que Sciascia leía con avidez.

Lucha el héroe, pues, hablando de España, de los pobres y los ricos, de la guerra, del fascismo, de Mussolini, y de hecho vehicula juicios sobre sus mismos destinatarios, es decir, sus compatriotas, desde sus amigos y familiares hasta los viejos y el secretario fascista, que no captan el significado de sus palabras engarzadas en discursos, en actividad crítica, incluso en juicios. Tales juicios, sin embargo, no son nunca veredictos; polémicos, sí, pero no hay en ellos pretensión alguna de autoridad: ${ }^{53}$ "La actividad crítica surge de una relación más estrecha de cuanto admita la opinión común». ${ }^{54}$

49 Walzer, «La guerra d'Algeria d'Albert Camus», cit., p. 185 y 192.

50 Sciascia, L'antimonio, cit., p. 228.

51 Cfr. Sozzi, Vivere nel presente, cit., p. 12.

52 Walzer, «La guerra d'Algeria d'Albert Camus», cit., p. 195. Cfr. nota 48.

53 Ib., pp. 195-96.

54 Ib., p. 193. 
—Pero ¿es bonita España? —insistían.

—Es como Sicilia — decía yo-. Hacia el mar muy bonita, llena de árboles y vińas; en el interior, árida, "tierra de pan» como decimos nosotros, y de escaso pan.

- ¿Son pobres los españoles?

- Los pobres lo son más que nosotros, y los ricos son tan ricos que dan miedo: toda una noche de tren se necesita para atraversar las tierras de un duque, un latifundio que no se acaba nunca.

—QQué cara! — decían mis amigos-. Aquí Mussolini está contra el latifundio y dice que los repartirá entre los campesinos; han pegado carteles en la plaza y allí dice así de grande: "Asalto al latifundio».

-En cambio en Espańa combatimos contra los que quieren repartir los latifundios entre los campesinos.

— ¿En España combatimos a favor de los ricos?

- A favor de los ricos, de los curas y de los esbirros — decía yo.

— ¿Cómo? Por los curas y los esbirros, se entiende, pero a los ricos Mussolini les trata como a cerdos.

- Por decir, puede decir lo que quiera — les expliqué-, pero ni vosotros ni yo veremos nunca quitarles algo a los ricos, mientras viva Mussolini.

Mi madre me oía lanzar estos discursos y con los ojos y los labios me hacía señas de callar [...]. Mi tío Pietro decía que no me reconocía, que cuando me fui apenas lograba decir, una tras otra, cuatro palabras, y ahora hablaba como un abogado de causas perdidas. Una locura: después de perder una mano en la guerra, buscarme a posta el destierro.

[...] con los viejos podía hablar sin límite, me escuchaban como si fuesen cuentos de los paladines de Francia, cosas lejanas [...].

El secretario fascista me miraba como si hubiese ido a hacer la guerra en Espańa por cuenta suya, en su nombre: se enorgullecía de la mano que yo había perdido; nuestro pueblo pesaba, gracias a mi mano, en la balanza de la victoria. ${ }^{55}$

No quiere Sciascia, en efecto, subrayar la autoridad — que queda como prerrogativa negativa y violenta del fascismo, de su poder, de su vacía retórica, falta de sujetos (políticos) y de juicios- sino la senda que va de la subjetividad al juicio, una senda que implica una iniciación al sujeto más problemática que la referida a la novela de formación militar, que de todas maneras es parte integrante, constitutiva, de aquella.

Tal iniciación, por cierto, tiene las características de un «desgarro violento» respecto a la comunidad — medida necesaria de ese mismo desgarro- e impone en consecuencia la asunción de cierta «distancia» por parte del héroe, que en cuanto rebelde no puede sino buscarse el destierro y pro-

55 Sciascia, El antimonio, cit., pp. 224-225 y 228. 
ceder, por tanto, hacia la segunda etapa, liminar pero felizmente representada, de su camino crítico: "Quiero ver cosas nuevas». ${ }^{56}$

El «regreso», en suma, "puede ser incluso una aventura peligrosa», como repite significativamente Ignazio Silone en "un singular cuento" de 1949 a 1964 y aun «con importantes modificaciones»-. Aquel Silone que, para Luce D'Eramo y luego para Giuseppe Papponetti, juega «la importante partida de una "voluntad de entender hecha de regresos" ».57

Se podría añadir, claro, que «el regreso es solo físico, mientras que la postura que se asume es moral, intelectual». ${ }^{58}$ Pero el minero del azufre necesita asumir esa postura interior, ética, en la distancia y necesita experimentarla en otra parte, más allá del regreso que le produce el «desgarro violento» frente a la comunidad, en cuyo seno la experiencia de la Guerra de España está destinada a no existir porque se convierte harto fácilmente en recuerdo, o sea, recuerdo de "cosas lejanas», "historias de paladines de Francia», y por eso no entra como tal -o como intersubjetividad, como arraigo de la subjetividad en el mundo- en la memoria colectiva. Nos encontramos ante el sueño de costumbre, en definitiva, y no ante una toma de conciencia. Y aquí Sciascia va más allá de esa «suerte de sorda y muda revuelta contra el mundo tal como es», que Camus propone en $E l$ extranjero (1942) — sin optar por el "registro patético», gracias a ese Meursault que «no llora, desea solo eclipsarse, reencontrar el sueño en un espacio cerrado" - y en La peste (1947), donde "se lee que para todos los prisioneros y para todos los exiliados el sufrimiento profundo consiste en "vivir con una memoria que no sirve para nada"».59

56 Ib., p. 230.

57 He aquí la cita completa: «una voluntad de entender hecha de regresos, en cada uno de los cuales se cumple un expolio sucesivo». Tal expolio, visto en perspectiva, parece oscilar en Sciascia entre el intento de salir del exilio y la ardiente desilusión de entrar en él de nuevo y para siempre, un poco como sucede con George Orwell, para quien remito a cuanto se dirá más adelante. Para Silone, véase «Ritorno a Fontamara», Comunità, 2, 1949, pp. 50-55; «La pena del ritorno», Tempo presente, mayo 1964, pp. 1-6 y el periódico Il Resto del Carlino, 23 de mayo de 1964. Cfr. además Luce D’Eramo, L'opera d'Ignazio Silone. Saggio critico e guida bibliografica, Mondadori, Milán, 1971, pp. 371-377, y Giuseppe Papponetti, «Silone ai piedi di un mandorlo», L'avvenire dei lavoratori, 3-4, 2003, pp. 131-142, en particular pp. 135-136.

58 Walzer, «Introduzione: la pratica della critica sociale», en L'intellettuale militante, cit., pp. 24-25, y el apartado «Il critico come eroe», pp. 23-28.

59 Sozzi, Vivere nel presente, cit., pp. 288-289. 
El minero sciasciano, que no logra hacer memoria de su experiencia y recuperar el sueño de costumbre, no llora sino que lucha, como exiliadohéroe, contra el profundo sufrimiento que consiste en "vivir con una memoria que no sirve para nada». Y por eso decide partir, porque si no puede hacer de la Guerra de España un recuerdo de "cosas lejanas", tampoco puede hacer de ella un auténtico recuerdo para todos - la "pregunta de un recuerdo"- y a la vez un dolor - la elaboración del dolor- a fin de poder decir, enunciar - y no borrar - los conflictos de la memoria individual y de la colectiva, que está como filtrada por una "memoria manipulada», o sea, por «abusos, en el sentido fuerte de la palabra, que provienen de una manipulación interesada de la memoria y del olvido por quienes ostentan el poder». ${ }^{60}$

Entonces la empresa crítica de nuestro héroe debe necesariamente continuar en otra parte, más allá de su démos e incluso de su generación. No se trata de evocar una víctima - acaso la víctima - o muchas: un familiar, el padre o los vecinos del pueblo. Porque, como sugiere Jacques Derrida, "la muerte de otro [...] no anuncia una ausencia, una desaparición, el fin de tal o cual vida [...]. La muerte declara cada vez el fin del mundo en su totalidad, el fin de todo mundo posible; cada vez, el fin del mundo como totalidad única y, por tanto, irreemplazable, infinita». ${ }^{61} \mathrm{No}$ se trata, sobre todo, de proclamarse víctima tout court y "pedir reparaciones interminablemente», jugando acaso con un «elogio incondicional de la memoria» (filtrado más bien por la herencia de "por quién doblan las campanas» y por una deuda moral con «la víctima ajena»). ${ }^{62}$

60 Ricoeur, La Mémoire, l'histoire, l'oubli, cit., p. 97; cfr. al menos las pp. 97-104.

61 Jacques Derrida, Chaque fois unique, la fin du monde, eds. Pascale-Anne Brault y Michael Naas, Galilée, París, 2003, p. 9. La edición original, sin la «Advertencia» por la que citamos (pp. 9-11), es la norteamericana: The work of mourning, Chicago University Press, Chicago, 2001 (Cada vez única, el fin del mundo, trad. Manuel Arranz, Pre-Textos, Valencia, 2005). La reflexión de Derrida parte de más lejos, al menos de Politiques de l'amitié, Galilée, París, 1994, y de Spectres de Marx, Galilée, París, 1993, donde sugiere que hay que aprender a vivir «con fantasmas o espectros» para elaborar «una politica de la memoria, de la herencia y de las generaciones». Cfr. Chaque fois unique..., cit., pp. 15-16, 40-41 y 259-289 (ensayo dedicado a "Lyotard et nous", aparecido en Dolores Lyotard, Jean-Claude Milner, Gérald Sfez (eds.), Jean-François Lyotard. L'exercise du différend, PUF, París, 2001, pp. 161196). Permítasenos remitir a Luciano Curreri, “"Dans la leurre du seuil”. I "Tombeaux" di Macrí e la "soglia” della poesia”, en Anna Dolfi (ed.), Per Oreste Macrí, actas de la jornada, Florencia, 9 de diciembre de 1994, Bulzoni, Roma, 1996, pp. 210-213.

62 Tzvetan Todorov, Les Abus de la mémoire, Arléa, París, 1995, pp. 13-14 (Los abusos de la memoria, trad. Miguel Salazar, Paidós, Barcelona, 2000). Cfr. Ricoeur, La Mémoire, l'histoire, l'oubli, cit., pp. 108 y 104. 
La memoria, en Sciascia, se presenta como un auténtico maremágnum, con sus vacíos, engaños, abusos y tal vez, al final, usos - no solo manipulaciones - del olvido y del ricœuriano pardon difficile; más allá, entiéndase, del fuerte sustrato religioso de Ricoeur y con una laica $-\mathrm{O}$ más laica- disposición para la búsqueda, gracias a un perdón que de todos modos no busca fáciles autoabsoluciones y cancelaciones sino que se propone aprehender y decir, enunciar - a un cuarto de siglo de la Guerra de España y del apogeo del fascismo italiano- el «sentido trágico de una comunidad fracturada y herida». ${ }^{63}$

Por otra parte, surgen reminiscencias que podríamos llamar anamnésicas: esfuerzos por recordar cuanto ha sido olvidado, a causa de una cierta "atrofia de la memoria». Atrofia que han contribuido a crear, a imponer, esos mismos vacíos, engaños, abusos, y que se enfrenta, cada vez más problemáticamente, a cierta "hipertrofia de la historia» respecto a la cual, a fin de cuentas, sería legítimo preguntarse si «lo contrario del olvido no es la memoria sino la justicia», ${ }^{64}$ esa "visceral ansia de justicia [...] y derecho» que, según Di Grado, hay que valorar si se quiere liberar «finalmente» a Sciascia de «la aureola de hagiógrafo de la derrota o del martirio». ${ }^{65}$

En definitiva, no se trata de proclamarse fácilmente — con actitudes «tradicionales»— una víctima/la víctima de la historia, de su invasivo, peligroso y orquestado imperialismo de la memoria y del olvido (ligado, conectado a la religión y/o al socialismo, al fascismo). Tampoco se trata de aumentar la distancia y aislarse desdeñosamente del mundo. Por lo demás, Sciascia no pone tal distancia sobre el tapete desde el comienzo; se entrevé solo al final del relato. La marcha del minero del pueblo se parece más a una «fuga», de hecho imposible y dictada por circunstancias (más adelante las exploraremos) que giran en torno al fuego y el miedo al antimonio.

63 Sofri, «Prima lettera. Ottobre 1997», en Tabucchi, La gastrite di Platone, cit., pp. 65-66.

64 Cfr. Yerushalmi, "Riflessioni sull'oblio», cit., pp. 9, 12-13, 24 y Ricoeur, La Mémoire, l'histoire, l'oubli, cit., pp. 105-111, 536-589 y 656.

65 Di Grado, «Sciascia, il cinema e (fra l'altro) l'Europa», cit., p. 70. Volveremos sobre el derecho y la justicia, especialmente en el epígrafe 5, citando y discutiendo Puertas abiertas (1987) de Sciascia. 
«Fuga» imposible, correlato de un «regreso» asimismo imposible, ciertamente significativa pero no construida "a expensas de vínculos familiares y ciudadanos», ${ }^{66}$ en el seno de los cuales el personaje sciasciano - dentro de ese regreso cuya imposibilidad debe experimentar- trata de colocarse de nuevo, siquiera sea como rebelde, o como hereje, profeta, intelectual a la contra, ${ }^{67}$ "abogado de causas perdidas».

El héroe, y también el crítico como héroe, que en esas figuras casi sinónimas (más afines que antagonistas) tiende a asomarse y manifestarse, tiene que asegurar de algún modo la «ruptura voluntaria con la comunidad», que se revela precisamente en el final abierto de El antimonio, donde adopta las características de un desapego que, podríamos añadir, es «una disminución de proximidad», un «alejamiento en el que deberíamos ejercitarnos», o bien "otro modo de acercarnos, una transformación de la proximidad [...] que remonta y resquebraja el modo común de conocer» y «nos invita a acostumbrar los oídos al ritmo de la subjetividad y de las cosas, a usar profundos tapones para no escuchar más el canto de esas sirenas que repiten, hasta el aturdimiento: conocer $=$ poder, siempre». ${ }^{68}$

Estas observaciones rovattianas, extraídas de Habitar la distancia (1994), podrían acompañarse con provecho de otras de Maurice Blanchot. En particular, las contenidas en Los intelectuales en cuestión (1984 y 1996), cuyo límite - límite general de toda discusión, más o menos reciente, sobre intelectual y compromiso, "palabra desusada y retórica" pero que habrá que conservar, como sugiere Berardinelli, ${ }^{69}$ acaso entre comillas- es no hacer autocrítica, desde los años 1936-1938, y difuminar mucho, por temor a las definiciones y sus derivas, el posible y fecundo vínculo entre «compromiso" y "pensamiento del peligro y contrario al peligro». Pensamiento útil para describir sintéticamente la postura comprometida del héroe/álter ego sciasciano en El antimonio, y que comparte Tabucchi en $L a$

66 Walzer, Lintellettuale militante, cit., p. 25.

67 Ib., p. 193.

68 Rovatti, Abitare la distanza, cit., pp. 36-37 y 40.

69 Berardinelli, L'eroe che pensa, cit., p. 5: «Pero la palabra compromiso, a su vez, es desusada y retórica; uno de esos términos de los que usan y abusan solo los políticos. Y las palabras de las que abusan los políticos quedan vacías de significado. Ni siquiera un periodista las usaría ya sin comillas». 
gastritis de Platón, "dedicada a la cara memoria de Leonardo Sciascia y Pier Paolo Pasolini, con mucha nostalgia». ${ }^{70}$

Traduzcamos, con Tabucchi, la hipótesis rovattiana con el «pensamiento del peligro y contrario al peligro" de Blanchot: "el intelectual estará más cerca de la acción, en general, y del poder cuanto menos se inmiscuya en la acción y menos ejerza el poder político. Sin desinteresarse de ambos. No se aísla distanciándose del político, sino que trata de conservar ese espacio de retirada, ese esfuerzo del retiro, para servirse de la lejana proximidad instalándose, precariamente, en ella [...]» — sobre las modalidades de esta precaria instalación, no sofocada por una prolongada exigencia de totalidad, volveremos en el segundo epígrafe-. "No quiere eso decir que no tome partido; al contrario, habiendo decidido según el pensamiento para él más importante, el pensamiento del peligro y contrario al peligro, resulta un obstinado [...] ${ }^{71}-\mathrm{y}$ de tal pensamiento, que en el relato de Sciascia se construye y delinea entre fuego, miedo y memoria, hablaremos en el epígrafe 5.

«Quiero ver cosas nuevas» no es, por lo tanto, un enunciado banal, un simple pasar la llamada. Por lo demás, solo tres páginas antes, esa voluntad de ver es «furor de ver cada cosa por dentro, como si cada persona, cada cosa, cada hecho, fuese un libro que uno abre y lee». ${ }^{72}$ Semejante comparación, ciertamente, responde a una situación emblemática, típica de Sciascia: "podríamos definirla libro dentro del libro —sugiere Claude Ambroise_-, ${ }^{73}$ situación interior que tiene como objeto la experiencia de conocer», y "conocer no es contemplar el uni-

70 Tabucchi, no obstante, parece servirse de él sobre todo como escudo (más o menos irónico) contra el «término "comprometido" [...] absolutamente inoportuno" por «su asociación con la idea comunista» que en Italia — más que en Francia u otros lugares- lo entrega a la «repulsión inmediata». Cfr. La gastrite di Platone, cit., pp. 36-39 y 51-52.

71 Cfr. Blanchot, Les intellectuels en question. Ébauche d'une réflexion, Farrago (Fourbis), París, 1996 (Los intelectuales en cuestión: esbozo de una reflexión, trad. Manuel Arranz, Tecnos, Madrid, 2003) y Tabucchi, La gastrite di Platone, cit., pp. 38-39. También de Blanchot, "Les intellectuels en question", Le Débat, 29, 1984, pp. 3-28, y las justas reservas de Tzvetan Todorov, Face à l'extrême, Seuil, París, 1991 (nueva edición: Points-Essais, 1994), pp. 124-125 [Frente al limite, trad. Federico Álvarez, Siglo XXI, México, 1993).

72 Sciascia, L'antimonio, cit., p. 227.

73 Ambroise, «Il libro nel libro», cit., p. 39. 
verso y la vida con frialdad analítica sino ir hacia cada cosa empírica y penetrarla, verla por dentro». Concluye Ambroise que es en virtud de «la elección de la literatura» como "hay que leer El antimonio, como un mito personal en que Leonardo Sciascia expresa su propia elección de escribir libros e identificarse con ellos». ${ }^{74}$ Podríamos, pues, concretar esa «situación interior» en el seno de un recorrido mauroniano que parte de la metáfora obsesiva del antimonio del título, y de la imagen del fuego dilatada en el relato, para desembocar en ese mito personal que evoca Ambroise.

Pero también podríamos concretar de otro modo esa «situación interior», glosando a Rovatti - lector del último Merleau-Ponty y su testamento El ojo y el espiritu (1960)_ para sugerir que el furor de ver cada cosa por dentro significa asimismo encontrar la mirada de las cosas, "colocarse como vidente en el interior": «Deberíamos entonces llegar a pensar, y a encontrar las palabras para decir, una experiencia que subvierta, o más bien invierta, el narcisismo de nuestro ojo", hasta el punto de que «el sujeto es sacado de su butaca de espectador, cortado en dos, digamos, y empujado sutilmente a (su) escena, a la vista de todos». ${ }^{75}$

Es significativo que la situación interior de que habla Ambroise se abra, siguiendo el pasaje de Sciascia, con la «indiferencia de todos ante las cosas tremendas que yo he vivido y que España vivía», o sea, con la indiferencia de todos al hacerse íntimamente partícipes del conflicto y compartir sus "consecuencias externas», sin captar una conclusión del yo narrador: «España también era una mina de azufre». ${ }^{76} \mathrm{Y}$, desde luego, no carece de significado el que tal indiferencia se mida simbólicamente gracias a un sujeto partido en dos, empujado a (su) escena y dividido entre un funeral y una fiesta de pueblo en que todos participan: la fiesta de San Calógero, que no por casualidad caracteriza, como en seguida precisaremos, un episodio importante que se cierra con un doble paralelismo y una ecuación: personaje adulto-Madrid bombardeada = personaje niño-fiesta de San Calógero.

74 Ib., p. 41.

75 Rovatti, Abitare la distanza, cit., pp. 57 y 66.

76 Sciascia, L'antimonio, cit., p. 228. 
Vista en perpectiva, tal estrategia — donde no puede dejar de asomar Roger Caillois, Guerra y fiesta, 1939— ${ }^{77}$ parece como si relegase a sus paisanos al misterio de una infancia que no se disuelve en la historia, no cae en el lenguaje o la palabra, mientras que el héroe accedería de nuevo a la infancia "como patria trascendental de la historia», "experimentando" ${ }^{78} \mathrm{de}$ forma cada vez más originaria y, en cierto sentido, colectiva. Es decir, no para ajustar cuentas con un pasado individual, cerrado, hundido en una guerra o en una mina.

Leamos completo ese pasaje:

En definitiva, me había venido el furor de ver cada cosa por dentro, como si cada persona, cada cosa, cada hecho, fuese un libro que uno abre y lee. También el libro es una cosa, que puedes poner sobre la mesa y mirarlo solo, lo puedes usar tal vez para enderezar una mesita coja o para atizarle a alguien en la cabeza, pero si lo abres y lees se torna un mundo. ¿Por qué no se deberían abrir todas las cosas y leerlas y ser un mundo?

Lo que más me hería y me dejaba más solo era la indiferencia de todos ante las cosas tremendas que yo había vivido y España vivía. Me sentía como quien, los días de fiesta por San Calógero o la Asunción, tiene que acompañar un entierro; la gente está loca de alegría, la plaza chorreante de vivos colores, y tú tras la carroza negra y amarilla que encierra un muerto, el corazón negro de pena, tienes que atravesar un túnel de alegría, te nace un rencor por la fiesta, por la gente que se divierte. Tal vez a todos los repatriados les escalda la indiferencia de los demás y se encierran en sí mismos, hasta que la vida de cada día, el trabajo, la familia, los amigos no les absorben de nuevo y les asimilan; pero cuando uno vuelve de una guerra como la de Espańa, con la certeza de que su casa arderá en el mismo fuego, no consigue hacer memoria de su expe-

77 Roger Caillois, «Guerre et fête», en L'Homme et le sacré (1939), ed. aumentada por tres apéndices: el sexo, el juego y la guerra en relación con lo sagrado, Gallimard, París, 1950, y Folio-Essais, 1993, pp. 224-225, dedicadas en concreto al «Tiempo de exceso, de violencia, de ultraje» (El hombre y lo sagrado, trad. Juan José Domenchina, Fondo de Cultura Económica, México, 1942). Cfr. también las páginas finales, «Regreso al caos» y "Paroxismos de la sociedad (Convulsiones paralelas, Epifanía de lo sagrado, De la fiesta a la guerra)", de un libro — cuya segunda y última parte es de 1951- del mismo Caillois, Bellone ou la pente de la guerre, La Renaissance du livre, Bruselas, 1963, pp. 195-208, 209223 (La cuesta de la guerra, trad. Rufina Bórquez, FCE, México, 1972).

78 Estoy pensando en Giorgio Agamben, Infanzia e storia. Distruzione dell'esperienza e origine della storia, col. Nuovo Politecnico, Einaudi, Turín, 1978, y nueva ed. ampliada, col. Piccola Biblioteca, Einaudi, 2001, p. 51: «Experimentar significa necesariamente, en tal sentido, acceder de nuevo a la infancia como patria trascendental de la historia. El misterio, que la infancia ha instituido para el hombre, puede de hecho disolverse en la historia, así como la experiencia, en cuanto infancia y patria del hombre, es algo siempre en grado de caer en el lenguaje y la palabra» (Infancia e historia, Adriana Hidalgo, Buenos Aires, 2004). 
riencia y recuperar el sueño de costumbre. Quiere, por el contrario, que los demás estén despiertos, que también ellos sepan.

Pero los demás querían domir. Tan pobre, de una pobreza vil, era mi pueblo que todos me decían con envidia: "Has hecho dinero, ahora puedes vivir tranquilo». Incluso los ricos me lo decían. Si no hubiese perdido una mano, habría vuelto a la mina: Espańa era también una mina de azufre. ${ }^{79}$

Es difícil no pensar en otro "regreso", a su manera, imposible, el del amargo final de Homage to Catalonia (1938), de George Orwell, texto «particularmente querido» ${ }^{80}$ para Sciascia sobre la Guerra de Espańa (y no solo), con «páginas que recuerdan la pluma del mejor Ernest Hemingway, del mejor Graham Greene», como propone Mario Maffi. ${ }^{81}$ También de aquel Greene amado por Sciascia, ${ }^{82}$ añadiríamos, que parte de un regreso similar para reformularlo después en clave policiaca, como ocurrirá con el Sciascia posterior a El antimonio. Pienso en El agente confidencial (1939), historia de un ex profesor de lenguas románicas que, tras pasar por los horrores de la guerra civil, vuelve a Inglaterra para convertirse, precisamente, en agente secreto. No es casual, entonces, que cuando Sciascia se impone como autor de novela negra, de casos policiales, desde los ańos sesenta y a lo largo de todos los ańos setenta, se acuerde del final de Homenaje a Cataluña en el prefacio de 1979 a una reimpresión, en la colección Oscar de Mondadori, El asesinato de Roger Ackroyd (1926) de Agatha Christie:

El libro es de 1938. Orwell lo escribió al volver de la guerra de España, y su temor, el temor a las bombas por las cuales Inglaterra sería despertada, era también una precisa profecía [...] las bombas alemanas sobre Inglaterra [...] Pero no es por esta profecía por lo que la página de Orwell me vuelve a la memoria cada vez que empiezo una novela de Agatha Christie [...]: es el "profundo, profundo sueño de Inglaterra» que para mí hace de obertura y telón de fondo. ${ }^{83}$

79 Sciascia, L'antimonio, cit., pp. 227-228.

80 Sciascia, Ore di Spagna, cit., p. 29.

81 Maffi, «Vagabondaggio ed esilio: George Orwell e la guerra di Spagna», en George Orwell, Omaggio alla Catalogna, col. Oscar, Mondadori, Milán, 1993, p. 258 (Orwell en España: homenaje a Cataluña y otros escritos sobre la guerra civil española, trad. AntonioPrometeo Moya, Tusquets, Barcelona, 2003).

82 Lo recuerda, por ejemplo, en Negro sobre negro (1979), cfr. Sciascia, Opere. 1973 1983, col. Classici, Bompiani, Milán, 1989 y 2001, p. 831, donde sin embargo se detiene, en medio de una gran estima, en una novela de Greene de los setenta, El factor humano (1978) (Negro sobre negro, trad. César Palma, Global Rhythm Press, Barcelona, 2007).

83 Sciascia, pról. a Agatha Christie, L'assassinio di Roger Ackroyd (1926), col. OscarGialli, Mondadori, Milán, 1992, pp. V-VI. 
Trasladando la expresión, podríamos concluir que es precisamente «el profundo, profundo sueño de Sicilia» — por algo está en las páginas finales («sueño [...] dormir») del último cuento de Los tíos de Sicilia, en su segunda edición (1960) — el que hace de "obertura y telón de fondo" de la narrativa sciasciana posterior, la que se tiñe de negro y se nutre de otros sueńos célebres, como The big sleep (1939) de Raymond Chandler —llevado a la pantalla en 1946 por Howard W. Hawks—, que entona, poco más o menos, el mismo lúcido y triste canto: «Dormimos el gran sueño, sin darnos cuenta de si hemos muerto mal, o si hemos caído en la inmundicia». ${ }^{84}$

En la Italia de los años cincuenta, de los que proviene El antimonio, se puede pensar en una consciente y difusa reacción, a medio camino entre la literatura y la filosofía, entre Natalia Ginzburg y Norberto Bobbio, por ejemplo, ante el vicio del silencio y el sueño dogmático tutelado, defendido por ese vicio. ${ }^{85}$ Mientras que en los sesenta, abiertos por El antimonio, yendo hacia un horizonte a la vez literario y cinematográfico, podríamos pensar en Il commissario Pepe (1965), de Ugo Facco de Lagarda —Ettore Scola dirigió en 1969 su adaptación: El comisario y la dolce vita-, cuya «vocación inquieta» ${ }^{86}$ parece replegarse y yacer en el «insomnio del comisario», estampándose, de principio a fin de la breve novela, contra el «sueño urbano» de una "pequeña ciudad septentrional», "común a otras ochenta ciudades, al menos, de Bolzano a Sicilia, de San Remo a Trieste». ${ }^{87}$ En la película de Scola, en cambio, el personaje añadido de Nicola Parigi (interpretado por Giuseppe Maffioli), otro mutilado de guerra, otro marginal, será quien denuncie la suciedad de una pequeña ciudad véneta e invite — hasta su trágica muerte (¿accidente o asesinato?) — a no dormir, a no abandonarse en el sueño.

84 Citado en Di Grado, «Sciascia, il cinema e (fra l'altro) l’Europa», cit., p. 72.

85 Ginzburg, «Silenzio», Cultura e realtà, 3-4, 1951, pp. 1-6, y Bobbio, «Politica culturale e politica della cultura", Rivista di filosofia, 1, 1952, pp. 61-74, luego en Politica e cultura, cit., pp. 18-30, sobre todo p. 26.

86 Cfr. Alessandro Scarsella (ed.), Ugo Facco de Lagarda 1896-1982: vocazione inquieta di uno scrittore veneziano, actas del congreso, Venecia, 7-8 de noviembre de 1997, Biblioteca Nazionale Marciana, Venecia, 1999.

87 Facco de Lagarda, Il commissario Pepe, Neri Pozza, Venecia, 1965, pp. 11, 14, 37, 44, 77, 99 y 101, donde el mismo comisario, «hombre habituado al insomnio», acaba rindiéndose y durmiendo «bien». 
Pero la narrativa posterior, negra, de Sciascia no se olvida - aun abriéndose a un género y a un cierto divertimento- de aquel ejercicio ético que representa El antimonio, anclado más en Orwell que en Chandler. Varios son, en efecto, los puntos de contacto entre la Inglaterra reencontrada al final de Homenaje a Cataluña y la Sicilia de El antimonio, aun cuando el final de este ensaya una superación, un querer ir más allá del universo siciliano, "a una ciudad lejana, fuera de Sicilia», ${ }^{88}$ es decir, fuera de las coordenadas más o menos dulcificadas de tal universo, por lo demás ya incardinadas, en el fragmento citado, en una apocalíptica visión orwelliana, al mismo tiempo profética e histórica.

La isla, la infancia (asociada también al tren en El antimonio, en un viaje a Palermo: acaso el Londres de Orwell, acaso ambas ciudades una representación de Madrid) ${ }^{89}$ el sueño y después, precisamente, las bombas, los incendios de la guerra, de los bombardeos («la certeza de que su casa arderá en el mismo fuego»), son fundidos por Sciascia y Orwell en la "tentativa de salir del exilio" y en la "ardiente desilusión» de volver a él, ${ }^{90}$ y para siempre. Piénsese, desde esta perspectiva, en el desenlace que ofrece, sin medias tintas, El caballero y la muerte (1986): "Ya he desembarcado en una isla desierta». ${ }^{91} \mathrm{Y}$ es realmente significativo que en esa "obra testamentaria, que resume todos los temas de la narrativa sciasciana», como dice acertadamente Traina, y cuyo "pensamiento se dirige a un lejano texto, La sexta jornada (1958), en que se expresaba admiración por el poeta Antonio Machado que [...] sigue con ardiente ansia la suerte de la guerra", ${ }^{92}$ se lean frases como estas: ${ }^{93}$

No es que no amase la tierra donde había nacido [...]. No habiendo regresado durante años, más allá de lo que allí sucedía, la buscaba en la memoria, en el sentimiento de algo que ya no existía. Ilusión, mixtificación de emigrante, de exiliado.

88 Sciascia, L'antimonio, cit., p. 230.

89 Ib., p. 202.

90 Maffi, «Vagabondaggio ed esilio», cit., p. 258.

91 Sciascia, Il cavaliere e la morte. Sotie, Adelphi, Milán, 1988, p. 67 (El caballero y la muerte, trad. Ricardo Pochtar, Tusquets, Barcelona, 2003).

92 Giuseppe Traina, La soluzione del cruciverba. Leonardo Sciascia fra esperienza del dolore e resistenza al Potere, Salvatore Sciascia Editore, Caltanissetta-Roma, 1994, pp. 130 131. Sobre La sexta jornada volveremos en el epígrafe 6.

93 Sciascia, Il cavaliere e la morte, cit., pp. 50-51, y p. 67: «No lo crea: ya he desembarcado en una isla desierta». 
Leamos, pues, con todos estos ecos, el pasaje (extractado) que cierra Homenaje a Cataluña de Orwell.

Y luego Inglaterra, la Inglaterra meridional, probablemente el paisaje más suave del mundo. Cuando se pasa por aquellas tierras [...] es difícil creer que algo esté sucediendo de verdad en otras partes del mundo. ¿Terremotos en Japón, carestías en China, revoluciones en México? No os preocupéis [...]. Las ciudades industriales estaban lejos [...]. Aquí estábamos todavía en la Inglaterra que he conocido en mi infancia: escarpes a lo largo de la vía del tren [...] y luego el gran desierto tranquilo de la periferia londinense [...], los señores con bombín, las palomas de Trafalgar Square, los autobuses rojos, los policías de azul — todos adormecidos en el profundo, profundo sueño de Inglaterra, del que a veces temo que no despertaremos nunca hasta que, de golpe, el estruendo de las bombas nos arranque de él. ${ }^{94}$

\section{Contra el síndrome del último intelectual y la exigencia de totalidad}

Volvamos a abrir la segunda edición de Los tíos de Sicilia y, siguiendo el índice, busquemos el último relato: El antimonio, cuento largo que podría convertirse incluso en la novela italiana de la guerra civil española, no obstante ser presentada cada vez más, mediante lecturas relativamente eficaces, especialmente para el primer Sciascia, situable entre Las parroquias de Regalpetra (1956), punto de partida escogido por el autor, y A cada uno lo suyo (1966), ${ }^{95}$ como un metarrelato en el que «España es solo un pretexto, como lo es Sicilia, para una reflexión más amplia sobre la escritura». ${ }^{96}$ Que

94 Orwell, Omaggio alla Catalogna, cit., pp. 185-186.

95 Sobre esta periodización, que oscila entre elecciones literarias, periodísticas y políticas, ofrece observaciones preciosas un reciente artículo de Traina, "Con l'emozione dell'azzardo". Appunti su Sciascia polemista», en Fernando Gioviale (ed.), La parola «quotidiana». Itinerari di confine tra letteratura e giornalismo, actas del congreso, Catania, 6-8 de mayo de 2002, Olschki, Florencia, 2004, pp. 71-88.

96 Christian Sorrentino, "L'Espagne et sa violence au coeur de L'antimonio de Sciascia», en Claude Ambroise y Georges Tyras (eds.), Violence politique et écriture de l'élucidation dans le bassin méditerranéen. Leonardo Sciascia et Manuel Vázquez Montalbán, n. ${ }^{\circ}$ especial de Tigre/Novecento, 2002, p. 68. Como vimos en el epígrafe anterior, el origen de estas observaciones (ciertamente más problemático) constituye el trabajo crítico de Ambroise, quien reconoce el valor metanarrativo de El antimonio sin desconocer la importancia del argumento y sus elementos vertebradores, a partir precisamente de España y Sicilia, como insistiremos más adelante siguiendo de nuevo a Ambroise. En el mismo número de la revista, cfr. también Ricciarda Ricorda, «Forme della violenza nella scrittura del primo Sciascia», pp. 71-82. 
la escritura en cuanto tal y la reflexión sobre ella sean un posible punto de arribo para Sciascia, y para casi todos los grandes escritores, me parece indiscutible. No lo es tanto el que ese punto de arribo confine con el ambiguo y por momentos banalizador terreno de los pretextos, los honores, las excusas, las ocasiones, y allí termine por relegar todos los signos de un destino histórico complejo que Sciascia se ha esforzado en interpretar y a su modo clarificar y experimentar, cruzando filosofía, crítica social y compromiso político, desde la tragedia de Espańa a la de Aldo Moro. Yo diría, en general, que una crítica más o menos joven, más o menos atenta a lo posmoderno, que tiende a privilegiar el divertissement — presente, claro está, en el autor siciliano, con variantes metaliterarias y metafísicassobreponiéndolo totalmente a un engagement que ya no parece tener curso en nuestros días, ${ }^{97}$ contribuye incluso a acercar a Sciascia, especialmente al segundo Sciascia, a escritores como Eco, esto es, opinion makers que trabajan más sobre la información que sobre la historia y/o más sobre citas de experiencia que sobre la experiencia misma.

Un apoyo militante y teórico a tales lecturas vendría, indirectamente, de un crítico muy distinto, que normalmente tiende a desestimarlas. Me refiero a Romano Luperini, que razonando sobre "Posmodernidad y posmodernismo» en Breve bilancio del secondo Novecento (1993) — retomado en Controtempo. Critica e letteratura fra moderno e postmoderno: proposte, polemiche e bilanci di fine secolo (1999) — sitúa a Sciascia (1921) y Eco (1932) en el mismo plano en cuanto opinion makers y, devaluando de hecho a ambos en una línea regresiva que conduce al escritor showman, los opone "a algunos escritores formados durante y después de la guerra" como Fortini (1917) y Pasolini (1922) y, "ya en distinta medida», Calvino (1923), Volponi (1924), Leonetti (1924) y Sanguinetti (1930), encajados todos en la definición que el mismo Luperini da del «escritor-intelectual»:

Defino como escritores-intelectuales a aquellos que, movidos por una exigencia de totalidad, no se quedan en los límites del especialismo, sino que conocen la gran cultura occidental — historia, política, filosofía- y sus principales literaturas, y buscan los vínculos entre ética y sociedad leyendo en unas y otros los signos de un destino histórico que se esfuerzan por interpretar y en el que pretenden influir, no solo con una actividad periodística o ensayística,

97 No solo "por su asociación con la idea comunista». Cfr. de nuevo Tabucchi, La gastrite di Platone, cit., p. 52. 
sino también con su obra narrativa y poética, o mejor, con el entrecruzamiento de todos estos terrenos de intervención [...]. Mientras Fortini, Pasolini o incluso Volponi y Sanguinetti presentan un campo de valores y significados, Sciascia y aún más Eco renuevan y americanizan una tradición de racionalismo y escepticismo laico que puede remontarse a Moravia y presentan un campo de competencias y criterios interpretativos, practican la distinción irónica, separan el sentido moral de la totalidad de un destino o un proyecto histórico y lo reducen así a buen sentido o sentido común: no son ya escritores intelectuales, sino, propiamente, escritores-opinion makers. ${ }^{98}$

Tengo la impresión de que el asunto es algo más complejo, sea para el segundo Sciascia, más difundido y problemático, situable entre los años setenta-ochenta, ${ }^{99}$ sea para el primer Sciascia, a caballo entre los años cincuenta y sesenta, ${ }^{100}$ que es el que aquí nos interesa. A propósito de este, no

98 Luperini, «Postmodernità e postmodernismo. Breve bilancio del secondo Novecento" (1993), en Controtempo. Critica e letteratura fra moderno e postmoderno: prosposte, polemiche e bilanci di fine secolo, Liguori, Nápoles, 1999, pp. 173-174. Léase entero, pp. 173-175, el epígrafe "La scomparsa dello scrittore-intellettuale», y sobre Eco, semiólogo entre la deriva y la defensa, las pp. 71-72, contenidas en "Una prolusione non accademica. Guerra del Golfo e tendenze della critica en Italia» (1991), ib., pp. 63-76. Son también los años de Zygmunt Bauman, La decadenza degli intellettuali (1987), Bollati Boringhieri, Turín, 1992, pp. 130-147, por tanto cfr. otra vez Berardinelli, L'eroe che pensa, cit., pp. XIXII. A propósito de Eco y los creadores de opinión, cfr. Lidia De Federicis, «I letterati come opinion makers", en Vittorio Spinazzola (ed.), Tirature 2003. Autori editori pubblico, Il Saggiatore/Fondazione Mondadori, Milán, 2003, pp. 62-68. Permítaseme, por último, citar a Luciano Curreri, «Pensieri sulla critica della traduzione e sulla sua ricezione», Palazzo Sanvitale, 15-16, 2005, pp. 174-189, ensayo escrito en 2002-2003 que debería haber sido publicado antes, con menos deslices, y completado en seguida por otro, más constructivo.

99 En ese sentido conviene revisar y matizar la invitación que aparece al final del trabajo, recomendable en general, de Alberto Cadioli, L'industria del romanzo. L'editoria letteraria in Italia dal 1945 agli anni Ottanta, Editori Riuniti, Roma, 1981, p. 171: "Habría también que indagar a fondo la transformación de la producción de Sciascia de los últimos años: el escritor es ya un personaje; primero sus polémicas con el partido comunista, luego su elección por las listas del Partido Radical, le han puesto cada más en el centro de la atención de un vasto público. Concede muchas entrevistas, discute de todo, se presenta como intelectual-guía de la opinión pública. Como escritor respeta el nuevo papel, y año tras año, puntualmente, saca un nuevo texto destinado al éxito (La desaparición de Majorana es de 1975, Los apuñaladores de 1976, Cándido de 1977, El caso Aldo Moro de 1978, Negro sobre negro de 1979, De parte de los infieles de 1980)".

100 Sobre el que apuntan, no por casualidad, muchas de las intervenciones del citado La responsabilità dell'intellettuale in Europa all'epoca di Leonardo Sciascia. Pienso, en particular, en los ensayos de Giulio Ferroni sobre Brancati, de Domenica Perrone sobre Vittorini y Sciascia, de Claude Ambroise sobre «Sciascia e la rivolta» (evocado más arriba), de Felice Balletta sobre Sciascia y Böll, y de Gigliola De Donato sobre «La coscienza divisa tra "sogno della vita" e "mondo della verità" nell'opera di Sciascia», respectivamente en las pp. $129-142,149-163,165-186,189-201$ y 213-232. 
sería demasiado complicado encajar buena parte de su trayectoria, entre historia, política y filosofía, entre ética y sociedad —entrecruzando sobre todo periodismo, ensayismo, narrativa y también poesía (Sicilia, su corazón, de 1952)—, en ese escritor-intelectual definido por Luperini. Así que no es difícil sustraerle, pues atraviesa un campo de valores y significados, a una supuesta tradición moraviana y llevarlo incluso a un horizonte pasoliniano-calviniano (más lo primero que lo segundo), tal vez desde 1950 (y hacia 1960: Pasión e ideología, de Pasolini), ${ }^{101}$ o desde aquellas sciascianas Fábulas de la dictadura que Pier Paolo Pasolini graba con ardor en una aguda intervención y "rueda» significativamente en Dictadura en fábula. ${ }^{102}$ No creo, en fin, que sea justo asociar a Sciascia, aunque sea en clave menor y en perspectiva, con la americanización y la ironía sin fin de Umberto Eco, que siempre ha asimilado con estilo y tempestividad norteamericanos las modas y los canales hermenéuticos del momento.

Aparte de a Sciascia, quizás debería someterse a discusión el punto de partida de la definición de Luperini, es decir, la exigencia de totalidad, especialmente cuando en la práctica crítica subsiguiente, luperiniana o no, se tiende a absolutizarla, hoy como ayer, frente a los límites del especialismo. Un especialismo percibido como algo totalmente negativo y, a menudo, travestido de subjetivismo sin anclaje en la historia, a partir de la crisis de la crítica (triste estribillo de estos ańos), acaso debida a ese «microfilologismo de medio pelo» y, como sugiere Luperini, a esa «exagerada proliferación de interpretaciones, denunciadas (con objetivos muy diversos de los míos) por Susan Sontag o, más eficazmente, por George Steiner». ${ }^{103}$

Aparte de las serias dudas que justamente podemos alimentar, con Mario Lavagetto y otros, sobre la eficacia de los discursos steinerianos, de Presencias reales (1989) en adelante, me parece que no es tan provechoso,

101 Massimo Onofri, Storia di Sciascia, Laterza, Roma-Bari, 1994, p. 34. Es notable, en la estructura del libro, la idea de la obra de Sciascia como «autobiografía de la nación», según el equilibrado e importante ensayo (por sus itinerarios y planteamientos críticos) de Giuseppe Traina, Leonardo Sciascia, Bruno Mondadori, Milán, 1999, p. 244.

102 Cfr. Nunzio Zago, «Il primo e l'ultimo Sciascia» (1991), en L’ombra del moderno. Da Leopardi a Sciascia, Salvatore Sciascia Editore, Caltanissetta-Roma, 1992, pp. 142-144. También, Nero su nero de Sciascia, cit., pp. 773-774.

103 Luperini, "Lettura, interpretazione e crisi della critica» (1993), en Controtempo. Critica e letteratura fra moderno e postmoderno, cit., p. 23. 
para hacer balance, usar como línea divisoria fuerte una exigencia de totalidad que, en última instancia, siempre se ha ańorado, frecuentemente dada por muerta en Fortini y luego hecha desaparecer con alguna prisa en autores como Sciascia. Se me ocurre pensar en Blanchot y Los intelectuales en cuestión (1984 y 1996), cuya lectura, más allá de las justas reservas de Todorov, ayuda a reaccionar contra quienes etiquetan y entierran prematuramente a los intelectuales y, en cambio, ofrece un camino a los que quieren acordarse de ellos, empezando, verbigracia, por ese Tabucchi que dedica La gastritis de Platón (1997 y 1998) a Leonardo Sciascia y Pierpaolo Pasolini. ${ }^{104}$

El síndrome del último intelectual, en definitiva, no contribuye a un balance que a veces se asemeja un poco - lo decimos con el mayor respeto a Fortini y Luperini- a una «rendición de cuentas». Una línea crítica, por fuerte que sea -ideológicamente fuerte-, no debe ni puede responder, y menos sola, a una exigencia de totalidad. Creemos más bien, con Blanchot de nuevo y con Sciascia (con el héroe-álter ego de El antimonio), que el intelectual, en su instalación precaria, en su pensamiento del peligro y contrario al peligro, es como mucho «un centinela que no está allí [en su precaria instalación] más que [...] para mantenerse despierto y esperar con una atención activa, que expresa menos una preocupación por sí mismo que una preocupación por los demás». ${ }^{105}$

La totalidad debe permanecer como una tentación para el intelectual, porque esconde — no, claro, en el caso de Luperini- una ambición peligrosa, y si bien puede servir de levadura, no debe ser el pan de cada día. Como reconoce con honestidad e ironía - por poner un ejemplo que nos ayude a ampliar el mapa y seguir pensando «la libertad por el conocimiento»— ${ }^{106}$ Pierre Bourdieu, que consecuentemente rehúsa hacerle un funeral al intelectual, punto de arribo inevitable, por el contrario, de quien absolutiza l'intellectuel total, idéal. Léase su Autoanálisis de un sociólogo, publicado póstumamente en 2004 , donde — dice Bernard Lahire a propósito del «compromiso público del intelectual»— «a pesar de haber teni-

104 Tabucchi, La gastrite di Platone, cit., p. 11.

105 Ib., p. 39: conclusión que recuerda la advertencia de Sartre.

106 Cfr. Jacques Bouveresse y Daniel Roche (eds.), La Liberté par la connaissance. Pierre Bourdieu (1930-2002), Collège de France, Odile Jacob, París, 2004. 
do la voluntad de constituirse contra "todo lo que representaba el programa sartriano", Bourdieu reconoce que ha sido trabajado por las ambiciones desmesuradas del intelectual total».107

Después de haber compartido un tiempo la visión del mundo del «filósofo de École Normal Supérieure de los años cincuenta» que Sartre llevó a su perfección - yo diría que a su paroxismo- $-[.$.$] , puedo decir que me he situa-$ do [...] contra todo lo que representaba para mí el programa sartriano. Lo que menos me gustaba de Sartre es todo lo que ha hecho de él no solo el «intelectual total», sino el intelectual ideal, la figura ejemplar de intelectual, y en particular su contribución sin parangón a la mitología del intelectual libre, que le valió el reconocimiento eterno de todos los intelectuales. [...]. No me alinearé nunca, sin embargo, entre aquellos que cantan hoy la muerte de Sartre y el fin de los intelectuales. ${ }^{108}$

\section{3. «Sabéis qué ha sido la Guerra de España? ¿Lo que ha sido de verdad?»}

Desde este punto de vista, augurando para Sciascia un nuevo balance, coral, en la segunda mitad del siglo XX, creo que será útil retomar las pocas observaciones citadas más arriba acerca del valor metaliterario de $E l$ antimonio. Aunque generales y extensibles, con mayor justeza, más allá del relato y del propio Sciascia, tales observaciones responden en parte a auténticas, complejas y todavía misteriosas razones compositivas, puestas ya de manifiesto por Ambroise, a partir del hecho de que El antimonio «es, en realidad, el inicio de una novela que habría debido tener mucho mayores proporciones, o las primeras páginas de una biografía que no tuvo con-

107 Lahire, L'Esprit sociologique, La Découverte, París, 2005, pero citamos por un extracto aparecido con antelación en Sciences Humaines, n. ${ }^{\circ}$ especial dedicado a "Pensées rebelles. Foucault Derrida Deleuze», 3, 2005, pp. 47-48. Lahire aborda luego el «intelectual universal», en terminología foucaultiana, al que Foucault mismo opone, como es sabido, el «intelectual específico»: «mientras Foucault desarrollaba y ponía en práctica la idea, más modesta y sin duda más eficaz, de intelectual específico». Con José G. Merquior, "Ritratto di un neo-anarchico», en Foucault (1985), Laterza, Roma-Bari, 1988, pp. 148157, y Michael Walzer, «La politica solitaria di Michel Foucault», cit., tengo algunas dudas sobre la eficacia de la aproximación foucaultiana, especialmente con el problema de la «distancia crítica» en el que ya me he detenido, en relación con Sciascia.

108 Bourdieu, Esquisse pour une auto-analyse, Raisons d'Agir, París, 2004, pp. 37-38. Cfr., en italiano, Questa non è un'autobiografia, Feltrinelli, Milán, 2005 (Autoanálisis de un sociólogo, trad. Thomas Kauf, Anagrama, Barcelona, 2006). 
tinuación, aparentemente, por motivos contingentes». ${ }^{109}$ En esa perspectiva biográfica se podría leer El antimonio como obra abierta, incompleta, al modo de Vittorini, ${ }^{110}$ para en seguida proponer un vínculo conceptual e intergeneracional que desarrollaremos, precisamente, en relación con la Guerra de España.

Pero todo eso no puede hacernos olvidar el testimonio del mismo Sciascia, que se dice "muy orgulloso» de El antimonio todavía en 1981, veinte años después de su publicación. No es casual que ese recuerdo cierre un párrafo abierto por una lista de libros que han contado la guerra civil y España:

Nos es particularmente querido el de George Orwell, Homenaje a Cataluña. Luego, Los grandes cementerios bajo la luna, de Bernanos, La esperanza, de Malraux, El diario, de Koltsov, las memorias del embajador norteamericano, las memorias de Pietro Nenni, de Constancia de la Mora, de Camillo Berneri, de Líster, del Campesino [...]. Y entre los muchos libros de poesía, hay uno que conservo como una de las cosas más preciosas que tengo: Maremágnum, de Jorge Guillén, con una dedicatoria que se refiere a ese cuento mío sobre la Guerra de España titulado El antimonio (del que han hecho una película que no he visto, pero me dicen que es buena), del que estoy muy orgulloso. ${ }^{111}$

109 Ambroise, Invito alla lettura di Leonardo Sciascia, cit., p. 95.

110 Natale Tedesco, "Avevo la Spagna nel cuore”: Sciascia, la Sicilia, la Spagna», en Natale Tedesco (ed.), Avevo la Spagna nel cuore, actas del congreso internacional, Nápoles, 15-16 de octubre de 1999, La Vita Felice, Milán, 2001, pp. 9, 11, 13. Cfr. además las intervenciones de Ricciarda Ricorda, "L'andare per Spagna di un siciliano: immagini di viaggio», pp. 191-207, y Domenica Perrone, «Sciascia, Vittorini e la Spagna», pp. 243-257, que tendremos ocasión de citar. Véase también Vicente González Martín, «España en la obra de Leonardo Sciascia», Cuadernos de Filología Italiana, 7, 2000, pp. 738-742.

111 Sciascia, Ore di Spagna, cit., p. 29. Entre los libros citados, aparte de presencias conocidas como las de Orwell y Malraux, de las que hemos hablado y hablaremos, y la de Bernanos (véase el tercer capítulo de este libro), tal vez sea interesante notar que algunos salen en Italia precisamente por los años de Los tíos de Sicilia y El antimonio. Cfr., por ejemplo, Pietro Nenni, Spagna, ed. Gioietta Dallò, Avanti!, Milán-Roma, 1958, con páginas publicadas e inéditas situables todas entre 1936 y 1942 (véase la nota de la editora, pp. 56), y Mijaíl Koltsov, Diario della guerra di Spagna, Schwarz, Milán, 1961 (Diario de la guerra española, trad. José Hernández, Akal, Madrid, 1978). En cambio, de los libros citados y reeditados en años más próximos a Horas de España, cfr. al menos el conocido y curioso caso de Constancia de la Mora, Gloriosa Spagna, pról. Luca Pavolini, «A Constancia de la Mora, hoy» de Rafael Alberti (agosto de 1975) e introd. Vittorio Vidali, L'Unità/Editori Riuniti, Roma, 1975, terminado de imprimir en octubre de ese año, poco antes de la muerte de Franco, en una edición no venal reservada a suscriptores del periódico comunista L'Unità del año 1976, es decir, como recuerda el prólogo, p. 7, en el «cuadragésimo aniversario de aquella heroica y desafortunada lucha del pueblo español contra el fascismo 


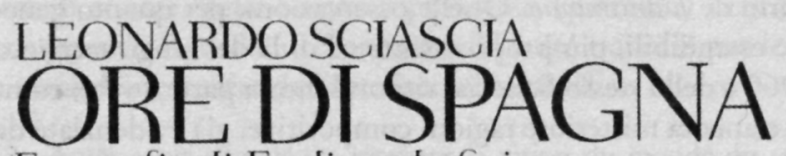

Fotografie di Ferdinando Scianna

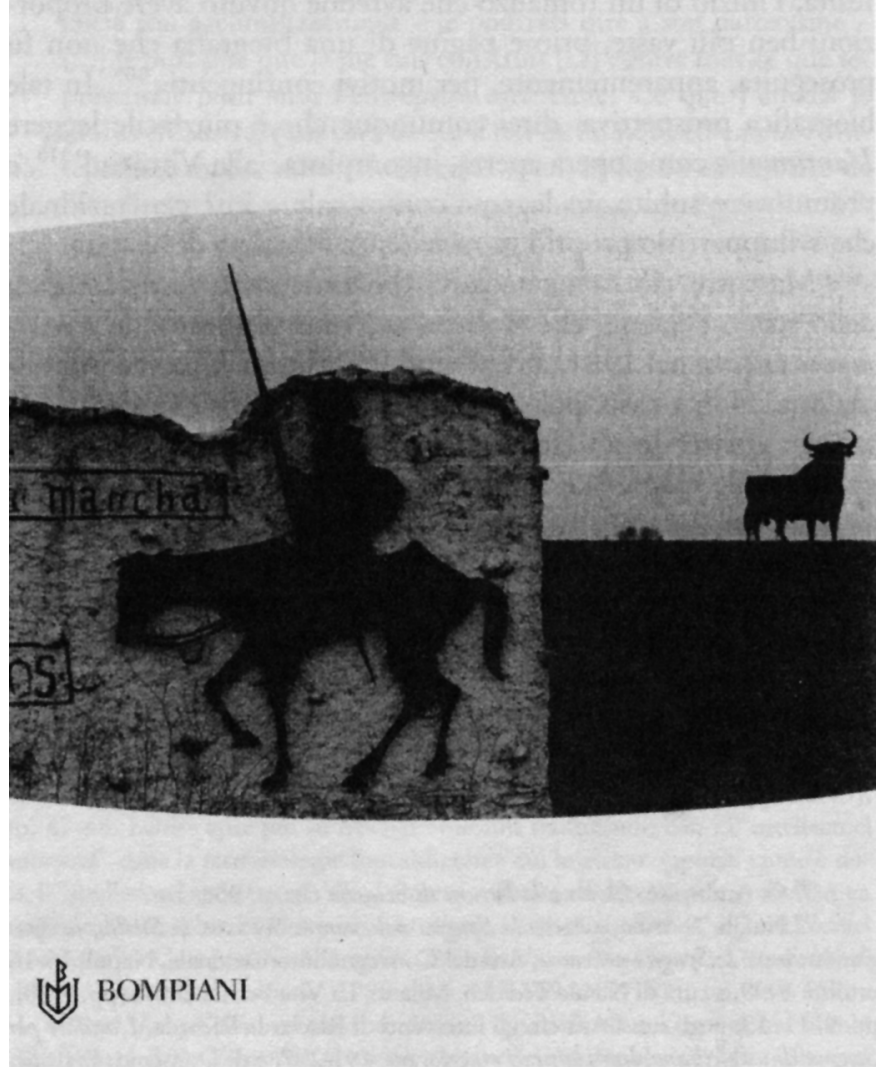


En este testimonio es fácil compartir, entre la dedicatoria y el cuento, el orgullo de Sciascia — no la opinión de los amigos que vieron la película, a la que volveremos - y apreciar en mayor medida a uno de los pocos escritores italianos del siglo XX que ha creído en un personaje y en un narrador que, "como las mariposas, de noche, en torno a la llama», "queman» su existencia literaria y civil «en torno a Madrid»: capital real y simbólica del conflicto, sitiada por los fascistas, y primera ciudad de Europa sometida — con "casas en que vivían miles y miles de personas»— ${ }^{112}$ a un duro bombardeo aéreo en el otońo-invierno de 1936, como prólogo a una "guerra a base de bombardeos $[. .$.$] guerra clara y abierta». { }^{113}$

interno e internacional, que fue el prólogo trágico de la segunda guerra mundial». La $1 .^{\mathrm{a}}$ ed. italiana del libro — aparecido en EE. UU. bajo el título In place of splendor. The autobiography of a Spanish woman (y en España con el de Doble esplendor, Crítica, Barcelona, 1977) - se remonta a 1951 (ib., p. 13).

112 Sciascia, L'antimonio, cit., p. 191. Para el largo y legendario asedio de la capital, entre bombardeos, resistencia y evacuaciones, así como obsesiones, miedos y fobias de los sitiadores, hojéese al menos el panorama que ofrece Carlos Serrano (ed.), Madrid 19361939. Un peuple en résistance ou l'épopée ambiguë, col. Mémoires, Autrement, París, 1991, libro al que nos referiremos en próximos capítulos.

113 Winfried Georg Sebald, Storia naturale della distruzione (2001), Adelphi, Milán, 2004, p. 31, que luego (pp. 140-141) remite a Elaine Scarry, La sofferenza del corpo (1985), Il Mulino, Bolonia, 1990. En conferencias ofrecidas en Zúrich en 1997, Sebald parte de los bombardeos, de la relación entre guerra aérea y literatura (Luftkrieg und Literatur, Carl Hanser Verlag, Múnich-Viena, 1997 [Sobre la historia natural de la destrucción, trad. Miguel Sáenz, Anagrama, Barcelona, 2005]), para diseñar una "cultura de los vencidos» que pone literariamente el silenciador a los «infiernos metropolitanos» y a los «incendios» de la Segunda Guerra Mundial en Alemania. Sobre estos «agujeros de la memoria» y sobre la «normalización» de la conciencia alemana en nuestros días ha escrito, más equilibradamente que otros en Italia, Gustavo Corni en L'Indice, 1, 2005, p. 5. Pero ahora cfr. «Sebald. Storia della distruzione e memoria letteraria», Cultura tedesca, 29, 2006 y Raul Calzoni, Walter Kempowski, W.G. Sebald e i tabù della memoria collettiva tedesca, Campanotto, Pasian di Prato (Udine), 2006. Sobre la «cultura de los vencidos», en general y en relación con Alemania, pero tras la Gran Guerra, véase Wolfgang Schivelbusch, «Essere sconfitti» y "La Germania» en La cultura dei vinti (2001), Il Mulino, Bolonia, 2006, pp. 7-38 (notas en pp. 275-290) y 175-265 (pp. 326-355); sobre «infiernos metropolitanos» e «incendios», en relación con Berlín y otras ciudades alemanas bombardeadas, léanse Mike Davis, «Lo scheletro di Berlino nell'armadio dello Utah", en Città morte. Storie di inferno metropolitano (2002), Feltrinelli, Milán, 2004, pp. 71-89 (Ciudades muertas: ecología, catástrofe y revuelta, trad. Dina Khorasane, Proyecto Editorial Traficantes de Sueños, Madrid, 2006) y Jörg Friedrich, La Germania bombardata. La popolazione tedesca sotto gli attacchi alleati 1940-1945 (2002), Mondadori, Milán, 2004 (El incendio: Alemania bajo el bombardeo, Taurus, Madrid, 2006). Sobre el cuerpo, en relación con la guerra, cfr. al menos Susan Sontag, Davanti al dolore degli altri (2002), Mondadori, Milán, 2003 (Ante el dolor de los demás, trad. Aurelio Major, Alfaguara, Madrid, 2003), y ensayos más recientes y comple- 
El antimonio elige, pues, el punto de vista de las tropas enviadas a España por Mussolini, pero forma parte de la mitografía antifascista sobre la guerra civil porque, como observa Gabriele Ranzato, «Sciascia se pone claramente de parte de la República, comparte las razones político-sociales de su lucha" y, en ese sentido, "hace también un elogio de la guerra civil», ${ }^{114}$ incluso yendo más allá del mito de la «paz» y hacia la «hora de la verdad» de la corrida, casi al modo de Hemingway:

Una guerra civil no es estúpida como una entre naciones, italianos contra ingleses o alemanes contra rusos, y yo, minero siciliano, que mato al minero inglés y el campesino ruso que dispara contra el campesino alemán. Una guerra civil es un hecho más lógico: un hombre se pone a disparar por las personas y las cosas que ama, y por lo que quiere, y contra aquellos a los que odia; nadie se equivoca al escoger de qué parte estar, solo aquellos que se ponen a gritar "paz» se equivocan. Creo que a Mussolini, entre todas sus culpas, no se le perdonará la de haber llevado a miles de italianos pobres a combatir contra espańoles pobres. Una guerra civil, a pesar de sus atrocidades, es una especie de «hora de la verdad", como llaman los espańoles al momento más álgido de la corrida. ${ }^{115}$

Pero no hay espectador en esta corrida. Todos debían bajar y bajaron de las gradas para combatir en el albero, en aquel inmenso coso que es la España de la guerra civil, como tendremos ocasión de subrayar. Todos, incluidos el narrador y el autor de El antimonio. Esta participación, aun cuando filtrada por «una ficción intelectual», es prueba de una responsabilidad individual (y de una elección moral, racional) manzoniana, y más que manzoniana: ${ }^{16}$ por un lado, Manzoni, con su llamada a la responsabilidad individual, sirve a Sciascia como antídoto contra las fáciles absoluciones del sociologismo, que ahoga toda culpa en la responsabilidad colec-

jos como los de Giovanni De Luna, Il corpo del nemico ucciso. Violenza e morte nella guerra contemporanea, Einaudi, Turín, 2006, pp. 101-117, 125-128 (El cadáver del enemigo, trad. Patricia Orts, 451 Editores, Zaragoza, 2007), y Valerio Giordano y Stefano Mizzella (eds.), Aspettando il nemico. Percorsi dell'immaginario e del corpo, Meltemi, Roma, 2006. Por último, casi circularmente, sobre la guerra aérea en el segundo conflicto mundial, en Italia y su frente sur, con Nápoles como ciudad herida en primera línea, ha escrito páginas introductorias, generalmente válidas, Gabriella Gribaudi, «La guerra vista dall'alto», en su libro Guerra totale. Tra bombe alleate e violenze naziste. Napoli e il fronte meridionale 1940-1944, Bollati Boringhieri, Turín, 2005, pp. 59-88.

114 Gabriele Ranzato, «Sciascia e la guerra civile spagnola: tra verità storica e verità letteraria", en Avevo la Spagna nel cuore, cit., p. 214.

115 Sciascia, L'antimonio, cit., p. 212.

116 Cfr. el comienzo del artículo de Traina, «L'eredità morale e letteraria di Leonardo Sciascia», Siculorum Gymnasium, 1, 2003, pp. 49-56. 
tiva o, si se quiere, cultural; por otro, Sciascia da prueba en El antimonio de un compromiso que va mucho más allá del catolicismo y de la razón burguesa, prueba de un pensamiento del peligro y contrario al peligro, en el que uno se quema, junto a los pobres, y para siempre.

No estamos, por tanto, ante un fácil divertimento, que si acaso se manifiesta, de modo nada banal, en otro nivel del discurso (técnico, citador, retórico). Tampoco ante una desvaída recuperación del conflicto español entre los muchos y trágicos «fragmentos» disponibles en el siglo breve, especialmente en el periodo delimitado por las dos guerras mundiales; fragmentos que parecen imponerse, como tales, en cierta narrativa italiana de principios de los sesenta —entre 1961 y 1963, digamos— ${ }^{117}$ y cristalizar en torno a temas como la historia y la guerra, de un lado, y la soledad y la marginalidad, de otro, en una creciente disparidad que ve al novelista, al artista, lejos de los escenarios de la historia, como anticipando la regresión de una vanguardia asociada a un lenguaje solipsista, que reescribe más o menos jocosa y alegremente el mundo, con sus consiguientes mutaciones.

El antimonio tampoco puede ser solo, como decíamos, un relato de sí mismo, de la propia escritura, si bien es con la escritura, con sus imágenes nutridas de literatura, como se asume y se representa un acceso nada fácil a la responsabilidad y al compromiso: de la imagen dilatada del fuego - impuesta desde el título y la primera página, de un modo estudiado y obsesivo, casi mauroniano_- ${ }^{118}$ a la de las mariposas que dan vueltas alrededor de la llama, más escondida y para nosotros más significativa, como trataremos luego de sugerir, acogiendo en ese sentido el juicio de Enrico Testa: «La tendencia hacia una lengua narrativa en que vuelven a aparecer, sea la sabiduría lingüística del literato italiano, sea toda la riqueza de fórmulas retóricas de la tradición, está ejemplificada en grado superlativo en la narrativa de Sciascia». ${ }^{119}$

117 Permítaseme citar mis artículos «La storia e la guerra nel Disertore e in altri romanzi del 1961", en Anna Dolfi (ed.), Una giornata per Giuseppe Dessí, actas del seminario, Florencia, 11 de noviembre de 2003, Bulzoni, Roma, 2005, pp. 65-82, y «Fra solitudine ed eccentricità: alcuni percorsi della marginalità ne La dura spina di Renzo Rosso", en Ada Neiger (ed.), Letteratura e marginalità, New Magazine, Trento, 1996, pp. 89-119.

118 Cfr. Charles Mauron, Dalle metafore ossessive al mito personale. Introduzione alla psicocritica (1963), Il Saggiatore, Milán, 1966. Piénsese también en lo que dije al final del primer epígrafe y en lo que diré en el quinto.

119 Testa, Lo stile semplice. Discorso e romanzo, cit., p. 327, que remite luego a Vittorio Coletti, Storia dell'italiano letterario, Einaudi, Turín, 1993, pp. 376-378. 
Por lo demás, para acceder a los muchos y diversos pensamientos y compromisos, ocultos, por estratos, en la guerra civil española, no bastan estudios, ni siquiera universitarios; acaso en el sentido que indicaría más tarde Enzo Paci, al hilo del 68, en el prólogo a la tercera edición italiana - la primera es de 1961 - de La crisis de las ciencias europeas y la fenomenología trascendental (1935-1937) de Edmund Husserl, donde aquella «dificilísima problemática fenomenológica [...] comprendida también por [...] la base popular de la sociedad», es la "fenomenología» que "ciencias, letras, artes y política hallan en sí mismas como una toma de conciencia»: «El problema se refiere entonces a la universidad como industria, $y$ al hecho de que la universidad haya perdido la finalidad y el significado de la verdad. En otras palabras: las universidades no enseñan una cultura para hombres y sujetos vivientes [...], los sujetos se dan cuenta de que se han convertido solo en objetos, que deben ser útiles al aparato industrial, político y militar»: ${ }^{120}$

Muchos estudian, van a la universidad [...] a estas personas les pediría: ¿sabéis qué ha sido la Guerra de España? ¿Lo que ha sido de verdad? Si no lo sabéis, no entenderéis nunca lo que pasa delante de vuestros ojos; no entenderéis nada del fascismo, del comunismo, de la religión, del hombre: nada de nada. Porque todos los errores y las esperanzas del mundo se han concentrado en esa guerra; como una lupa que concentra los rayos del sol y quema, así se encendió España con todas las esperanzas y los errores del mundo, y en ese fuego crepita hoy el mundo. ${ }^{121}$

A propósito de fuego, luz, encender, crepitar, arder, ya no es posible posponer ese pasaje con que hemos titulado el libro y que se encuentra hacia el final de la primera parte de El antimonio.

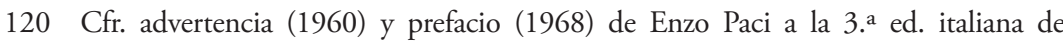
Edmund Husserl, La crisi de le scienze europee e la fenomenologia trascendentale (1959), Il Saggiatore, Milán, 1961, 1969 y Net, Milán, 2002, pp. 10, 12 y 15 (La crisis de las ciencias europeas y la fenomenología trascendental, trads. Jacobo Muñoz y Salvador Mas, Crítica, Barcelona, 1991). Es el último gran trabajo de Husserl entre los años 1935 y 1937. Entre los 30 y los sesenta, a nuestros efectos, es difícil no pensar en Marcuse y su prólogo (1964) a Cultura e società. Saggi di teoria critica 1933-1965, Einaudi, Turín, 1969, pp. XVII-XXV (Cultura y sociedad, trads. E. Bulygin y E. Garzón Valdés, Sur, Buenos Aires, 1970), escrito para sus intervenciones de los años teinta (la última es de 1938), donde señala la fractura entre pasado y presente en "Auschwitz» (p. XX) pero justo después evoca la "guerra civil española», sobre los "campos de batalla y de exterminio», en la que «se luchó por última vez por la libertad, la solidaridad y la humanidad en sentido revolucionario», precisando en nota: «Por última vez en Europa. La herencia histórica de esta lucha hay que encontrarla hoy en aquellos países que defienden su libertad sin compromisos contra las potencias neocoloniales» (p. XXI).

121 Sciascia, L'antimonio, pp. 203-204. 


\section{4. «Mariposas en torno a la llama». Breve historia de una imagen}

En El antimonio se identifican un narrador interno, el protagonista, y obviamente enunciados en tercera persona para las acciones llevadas a cabo por los demás, de las que ya el inicio es testimonio: «disparaban desde el campanario». ${ }^{122}$ Presencia obvia pero significativa la de estos enunciados, pues tienden a compensar el profundo análisis de un personaje. Análisis del arraigo de la subjetividad en el mundo, en un contexto histórico determinado, pero no de una vez por todas, como decíamos, y desde luego dilatado, gracias sobre todo al uso de ciertas imágenes (fuego, pero también mariposas) y a los nada raros saltos temporales a la infancia del protagonista y a momentos posteriores a la experiencia de la guerra — si bien todavía incrustados en ella, en su tiempo- y también quizás, en el final abierto y en perspectiva, después del Ventenio fascista.

Por otra parte, como veremos, si los enunciados en tercera persona se refieren sobre todo a acciones llevadas a cabo por otros, pueden también, en cierto modo, alcanzar a las realizadas por «un yo que habla en nombre de un nosotros», ${ }^{123}$ es decir, un "yo» que —además de representar a "personaje y escritor, España y Sicilia», como sugiere Tedescose vuelve comunidad de soldados, encarnándose primero en la pluralidad del «dábamos vueltas» — pluralidad también de «nosotros los habitantes de esta tierra, cualesquiera hombres de hoy»— ${ }^{124}$ y luego en la pluralidad de la tercera persona del plural: «mariposas» que «se aproximan» peligrosamente «a la llama» de Madrid, a Madrid-llama, hasta terminar identificándose con ella, símbolo de la sufrida y generalizada condición humana.

Dábamos vueltas en torno a Madrid, como las mariposas, de noche, se aproximan a la llama hasta sentir que se queman y amplían el vuelo, de nuevo se aproximan y, por un soplo de viento, la llama les atrapa. ${ }^{125}$

122 Ib., p. 167.

123 Tedesco, "Avevo la Spagna nel cuore”: Sciascia, la Sicilia, la Spagna», cit., p. 12. También para la cita siguiente.

124 Rovatti, Abitare la distanza, cit., p. 22.

125 Sciascia, L'antimonio, cit., p. 189. 
Una imagen similar, «dar vueltas [...] como una mariposa de calavera alrededor de la llama», anticipada no casualmente por la evocación de Franco, el Generalísimo vencedor de la guerra civil española, vuelve a la obra de Sciascia en A cada uno lo suyo, cronológicamente cercana (1966). En este caso se trata de un "novela policiaca que no lo es», como escribe Italo Calvino, ${ }^{126}$ una novela policiaca «desmontada» donde incluso se propone una exégesis de esa preciosa y poética imagen «por deformación del oficio", tras un diálogo entre Rosello y Laurana, entre el sospechoso y el protagonista, un profesor que "hacía trabajillos de crítica» ${ }^{127}$ y se metía a hacer de detective:

—La derecha del diputado está más a la izquierda que los chinos, si quieres saberlo... [dijo Rosello].

—Pero ¿el diputado Abello — preguntó [Laurana]— acepta totalmente la línea que por ahora sigue vuestro partido?

- ¿Y por qué no? Durante veinte años hemos arañado votos a la derecha; ahora es el momento de empezar a hacerlo a la izquierda. Total, no cambia nada.

- ¿Y los chinos?

— ¿Los chinos?

—O sea, si el diputado está más a la izquierda que los chinos...

- Pero cómo sois los comunistas: de una frase hacéis una cuerda, y con ella colgáis a un hombre... Lo he dicho por decir. Si te apetece, también te puedo decir que está a la derecha de Franco.

[...] Se fue, con la cara un poco turbada, sin saludar.

Volvió al cabo de media hora, completamente cambiado: alegre, afectuoso, dispuesto a bromear. Pero Laurana advirtió la tensión, la inquietud, acaso el miedo, que le impulsaban a dar vueltas "como una mariposa —así pensó-, como una mariposa de calavera alrededor de la llama»: y la imagen, sacada de una página de Crimen y castigo, acabó por deformación del oficio aplastada en una nota a Gozzano, o a Montale. [...]. Así terminó Rosello por quemarse las alas, en la llama de la sospecha de Laurana. Casi daba pena. ${ }^{128}$

Después de Fiódor Mijailovich Dostoievski, ${ }^{129}$ el profesor y crítico literario Laurana - como lo es Sciascia — remite a Guido Gozzano y a Eugenio Montale. La prosa «detectivesca» de Crimen y castigo (1866) se con-

126 Citado por Ambroise, "Cronologia», en Leonardo Sciascia, Opere 1956-1971, col. Classici, Bompiani, Milán, 1989 y 2001, p. LIX.

127 Sciascia, A ciascuno il suo, Einaudi, Turín, 1966, y en la col. Nuovi Coralli, 1973, p. 29.

128 Ib., p. 84.

129 Aparte la precisa indicación de Sciascia, pronto volveremos sobre Dostoievski —aun siendo conscientes de la conocida (pero tardía) preferencia sciasciana por Tolstói- a propó- 
vierte en la poesía de la Acherontia atropos, «De la calavera», en las Mariposas (1908-1916) gozzanianas. ${ }^{130}$ Para Montale — que, como observa Cesare Segre, ${ }^{131}$ "con alguna artificiosidad ha elevado un tema crepuscular a la intensidad atormentada por relámpagos metafísicos propia de su poesía»— la mariposa es motivo bastante frecuente, un símbolo nada raro, desde los "Viejos versos» de Las ocasiones (1928-1939) hasta "Para un homenaje a Rimbaud» de La tormenta y otros poemas (1940-1954): motivo y símbolo desplegados también en una breve prosa - Mariposa de Dinard, que cierra un librito homónimo de 1956 - pero ya en clave crítica, incluso autoirónica; en definitiva, una relectura reflexiva y divertida de sí mismo.

Creemos que el fragmento citado adopta ese registro por partida doble, traduciendo la pasión civil y el compromiso de las pesquisas de Laurana en un divertimento, en un juego literario y, luego, en una exégesis que parece llevar a una autoexégesis, como si ambas se espejasen, siguiendo modelos metanarrativos, en el título mismo de la novela: $A$ cada uno lo suyo.

sito del incendio que domina el fragmento de las mariposas en El antimonio, especialmente las frases finales, que apuntan otra posible ascendencia dostoievskiana en las llamas que ponen fin a «La fiesta» en la tercera y última parte de Los demonios (1873). Por el momento, reléase Crimen y castigo, Istituto Geografico De Agostini, Novara, 1982, vol. I, p. 368 (entre muchas traducciones españolas, la de Isabel Vicente para Cátedra, Madrid, 1996), cuando Raskólnikov piensa: «¿Hago bien o no yendo hasta él [el juez Porfirio]? También la polilla se precipita sobre la llama». O cuando (vol. II, p. 22) Porfirio dice a Raskólnikov: «¿Alguna vez le ha sucedido ver a una mariposa ante una vela? Pues bien, también él [el asesino de la vieja usurera y su hermana Lizaveta, es decir, Raskólnikov] dará vueltas en torno a mí, continuamente, como si estuviera alrededor de una vela». Y en el vol. III, p. 277, encontramos una posible conexión con El antimonio, que tiene origen y parábola distintos pero concebidos y diseñados en esa extensa "época de la guerra civil subrepticia» - conciencia de unos pocos rebeldes, aislados en un contexto de pobreza y miseria-, que al final del libro Raskólnikov asimila tout court a la guerra poco antes de expiar su culpa en el dolor del exilio, necesario para volver a entrar en aquella sociedad (humanidad) por la cual ha cometido el delito: «iNo entiendo por qué matar con bombas a la gente en una ciudad sitiada debiera parecer formalmente más conveniente!» Cfr., en fin, para la «época de la guerra civil subrepticia» y en relación con Crimen y castigo, Massimo Ilardi, Negli spazi vuoti della metropoli. Distruzione, disordine, tradimento dell'ultimo uomo, Bollati Boringhieri, Turín, 1999, p. 65.

130 Gozzano, Tutte le poesie, ed. Giacinto Spagnoletti, Newton Compton, Roma, 1993, pp. 139-142 (en español pueden leerse El altar del Pasado, Planeta-De Agostini, Barcelona, 2000 y Poemas de Guido Gozzano, trad. Carlos Pujol, Comares, Albolote [Granada], 2003).

131 Segre, "Invito alla "Farfalla di Dinard"”, en I segni e la critica, Einaudi, Turín, 1970, y Marco Forti (ed.), Per conoscere Montale, antología acompańada de textos críticos, col. Oscar, Mondadori, Milán, 1986, pp. 266-267. 
Por un lado, en la repetida boutade de Rosello, tenemos una desmitificación de la derecha franquista y de la política en general, incluso de izquierdas, cuyo fracaso constata el libro más allá del género "policiaco» o del tema de la «mafia». A esa boutade sigue, oscilando entre el pensamiento de Laurana y el comentario irónico del narrador, la revelación de un gusto poético por la imagen que, por obvias adherencias regionalistas, podemos retrotraer a Giacomo da Lentini ${ }^{132}$ ( Si como 'l parpaglion» [Sé como la mariposa]) y que parece reformular el contexto trágico de la Guerra de España (y de El antimonio) y adaptarse al amargo clima de sospecha de la Sicilia de Sciascia, donde arraiga otra guerra civil, acaso más subterránea pero no menos peligrosa, al punto de que "los policías tristes de Leonardo Sciascia» se convierten en "legionarios [...] capaces de desencadenar, a partir de cúmulos de pena y cansancio, ese felino arqueo de riñones que es la poesía». Como bien sugiere Di Grado, lector éticamente atento al mundo del escritor siciliano incluso en su dimensión noir, replegada un tanto unilateralmente y según coordenadas estéticas antes inadvertidas «en el frente de una región metafísica», que lleva a los legionarios-policías a una «necesidad de belleza que les embruja y les pierde». ${ }^{133}$ Razonando de otro modo sobre la circularidad que se da entre el comienzo y el epílogo de la obra sciasciana, Zago nos ayuda a concentrarnos en una Sicilia menos metafísica y más concreta, la del primer Sciascia, para entender también al Sciascia posterior, sobre todo el último, y en tal sentido recuerda, después de los subrayados de Ambroise, el ya citado librito Sicilia, su corazón (1952), en particular el poema "A un pueblo abandonado", donde destacan los siguientes versos:

Entre estos hombres he aprendido dolorosas leyendas de tierra y de azufre, oscuras historias desgarradas por la trágica luz blanca del acetileno. ${ }^{134}$

132 O a Chiaro Davanzati, «Il parpaglion che fere a la lumera» (La mariposa que va a la luz).

133 Di Grado, «Sciascia, il cinema e (fra l'altro) l'Europa: (bianco e) nero su nero», cit., pp. 71-72.

134 Zago, «Il primo e l'ultimo Sciascia», cit., pp. 146-147. Pero cfr. Ambroise, Introduzione a Sciascia, cit., p. 16, y las páginas sciascianas sobre La mina de azufre (1963) incluidas en La cuerda loca. Escritores y cosas de Sicilia (1970), en Opere 1956-1971, cit., pp. 1096-1101. 
Por otra parte, Sciascia se burla del prurito investigador de Laurana y de sí mismo en cuanto literatos, jugando con el lector, pero sin engañarle, acerca de la capacidad crítica racionalista de su héroe y álter ego. Al final, de hecho, el lector quedará desilusionado o bien, con una estrategia bastante habitual, no ilusionado, al mismo tiempo que se le invita a una toma de conciencia y a una actitud desencantada, puesto que no será Rosello quien se queme las alas en la sospecha de Laurana sino, precisamente, Laurana el que verá quemar las suyas en la sospecha de Rosello.

\section{El fuego, el miedo, la memoria, la infancia $\mathrm{y}$ «los muchachos hambrientos, con hambre de ciudades nuevas y de ver mundo»}

Esta rápida incursión en $A$ cada uno lo suyo (1966) y en los primeros pasos poéticos de Sciascia nos ha permitido poner literariamente de relieve una imagen significativa para nuestro propósito y establecer un ulterior y no tan evidente vínculo dentro de esa construcción cultural impura que se vale de la «continuidad» explosiva entre España y la Sicilia de Sciascia. ${ }^{135}$ Ese primer Sciascia que podemos intentar colocar entre 1952 - teniendo presente la atención de Pasolini a las Fábulas de la dictadura (1950) - y 1966, entre poesía y narrativa, entre tradición —o una idea ampliada de tradición, que responde más bien a un conjunto de tradiciones- y retórica, sabiduría lingüística; y luego, si se quiere, entre compromiso y divertimento, pero en el sentido ya anticipado.

Hay que precisar en seguida que tal divertimento nunca es fin en sí mismo y que la retórica y la sabiduria lingüística no son únicamente oficio, es decir, no se traducen solo en el factor técnico que, ciertamente, es innegable en Sciascia, invitado por un escritor de oficio como Calvino a "no abandonarse al oficio» ${ }^{136}$ (y Calvino, el oficio, se lo roba incluso a los

135 Cfr. una carta de Italo Calvino, del 26 de octubre de 1964, citada por Tedesco, "Avevo la Spagna nel cuore": Sciascia, la Sicilia, la Spagna», cit., p. 14, y también por mí más adelante.

136 Traina, Leonardo Sciascia, cit., p. 229. Cfr. Calvino, I libri degli altri. Lettere 19471981, ed. Giovanni Tesio, "Nota» de Carlo Fruttero, Einaudi, Turín, 1991, pp. 192, 216, 235, 239, 308, 490 (Los libros de los otros, trad. Aurora Bernárdez, Tusquets, Barcelona, 1994). 
críticos). ${ }^{137}$ En Sciascia, la retórica y la sabiduría lingüística pueden desde luego servir al maremágnum de la memoria y del recuerdo, incluyendo sus corolarios: no recordar, no hacer memoria de la propia experiencia. Todo mira, sin embargo, a subrayar una toma de conciencia, un compromiso, y en ese sentido promueve también un entrecruzamiento consciente y no tan frecuente entre obra narrativa y poética, del mismo Sciascia y de otros. De hecho, más allá del claro antecedente dostoievskiano y de las Mariposas de Gozzano, "el loco aleteo de la mariposa» de los «Viejos versos» de Montale es «objeto y catalizador del recuerdo», ${ }^{138}$ como lo son las vueltas que dan las mariposas-soldados en El antimonio.

Leamos, pues, (casi) por entero ese fragmento que, en sus primeras frases, está marcado por la imagen de la loca danza, pero, por seguir con la argumentación del recuerdo y la memoria, prestemos particular atención al comienzo y al final:

Mientras estaba sentado en la escalinata de la iglesia de San Isidoro, en aquel pueblo de cuyo nombre no me acuerdo, la batalla de Santander acababa de empezar. Era el 15 de agosto de 1937. Dábamos vueltas en torno a Madrid, como las mariposas, de noche, se aproximan a la llama hasta sentir que se queman y amplían el vuelo, de nuevo se aproximan y, por un soplo de viento, la llama les atrapa. Así era Madrid. [...]. No sé por qué, de los pueblos y ciudades de España no guardo un nítido recuerdo: tampoco de Sevilla, la ciudad más hermosa que haya visto nunca. No tengo buena memoria para los lugares, pero todavía menos para los de Espańa; tal vez porque los pueblos se parecían mucho a los que yo conocía de niño, el mío y los más cercanos, y decía: «Este pueblo es como Grotte, aquí me parece estar en Milocca, esta plaza es como la de mi pueblo». Incluso en Sevilla me parecía caminar por momentos por las calles de Palermo, en torno a la plaza Marina. Y también el campo era como el de Sicilia: Castilla, desolada y solitaria como la tierra entre Caltanissetta y Enna, pero con una desolación y una soledad más vastas, como si el Padre Eterno, después de haber abocetado Sicilia, se hubiese complacido en un juego de ampliaciones con uno de esos aparatos que venden en las ferias y que usan también los ingenieros, pantógrafos los llaman. ¡Qué idea, plantar una capital en pleno centro de Castilla! Que en medio de aquel desierto hubiese una ciudad grande y hermosa parecía increíble; era solo una idea alucinada, que surgía como surge en el sediento la imagen del agua que brota. Pero Madrid existía: de noche reverberaba rojo en el cielo, por los incendios que nuestros aviones iban a desatar; solo en algunos momentos pensaba que en

137 Cfr. Giovanni Palumbo, «Le prince Andréj e il volo di Cosimo: chiose sul finale del Barone rampante», Critica letteraria, 124, 2004, p. 454.

138 Cfr. Antonio Zollino, «Su "Vecchi versi" di Montale. Fra il tempo degli "Ossi” e i luoghi di "Alcyone"”, Rassegna Lucchese, 2, 2000, p. 15. 
aquella ciudad había niños y viejos, mujeres que gritaban sus penas y casas en que habitaban miles y miles de personas. Pensaba: "el antimonio, el fuego", pero la reverberación era tan lejana, nos costaba tanta sangre y dolor aquella ciudad alucinante, que generalmente miraba la aureola roja de la muerte como cuando era niño, en el campo, miraba las lejanas girándulas de fuego de la fiesta de San Calógero: un luminoso y lejano juego de la noche. ${ }^{139}$

De este pasaje, delimitado en el relato por dos espacios blancos y perfectamente cerrado, hemos suprimido solo una veintena de líneas para evidenciar mejor la problemática continuidad del discurso sciasciano sobre la memoria ("de cuyo nombre no me acuerdo»; «No sé por qué [...] no guardo un nítido recuerdo"; "No tengo buena memoria») relativa a los lugares de la guerra, los pueblos, los campos, las ciudades y esa capital que los introduce («Así era Madrid») y vuelve al final para superarlos y englobarlos a todos («Pero Madrid existía») en una imagen de fuego, que se sobrepone a la del agua, recurrente solo en la alucinación que la ve brotar.

Desde esta perspectiva, el fuego, que ciertamente es muerte, «ejercicio del apocalipsis», como sugiere Malraux en La esperanza (1937), ${ }^{140}$ parece tornarse pronto, bachelardianamente, su contrario: vida, alimento, placer. Para verificarlo basta leer unas cuantas líneas de Psicoanálisis del fuego, terminado en diciembre de 1937 y publicado en 1938:

[El fuego] es cocina y apocalipsis. Placer para el nińo [...] castiga, no obstante, toda desobediencia cuando queremos jugar demasiado cerca de sus llamas. ${ }^{141}$

El fuego, con el que no se bromea, como dice el proverbio, ofrece también fuerza vital, alimento, alegría (alegría infantil, originaria), a esa memoria que se enfrenta de modo más problemático que ingenuo, divertido o «vacacional», con la historia y el olvido, el perdón, la justicia, ${ }^{142}$ y

139 Sciascia, L'antimonio, cit., pp. 189-191.

140 André Malraux, «Exercise de l'Apocalypse», en L’Espoir, Gallimard, París, 1937 y col. Folio, 1972 y 1989, pp. 141-303 (La esperanza, trad. José Bianco, Cátedra, Madrid, 1995).

141 Gaston Bachelard, La Psychanalyse du feu, NRF, París, 1938, y col. Folio-Essais de Gallimard, 1985 y 1995, pp. 23-24. Para el positivo revés bachelardiano, dentro de la tetralogía de la materia, cfr. Luciano Curreri, «Les images avant les idées», Franco-Italica, 13, 1998, pp. 177-218.

142 Cfr. otra vez Ricoeur, La Mémoire, l'histoire, l'oubli, cit., y Yerushalmi, «Riflessioni sull'oblio", cit. 
que alterna sentimientos de participación y sufrimiento (especialmente de los niños, los viejos, las mujeres) con sentimientos de separación, miedo, peligro, instinto de supervivencia, cuando no de destrucción, y juegos un tanto embriagadores:

solo en algunos momentos pensaba que en aquella ciudad había niños y viejos, mujeres que gritaban sus penas y casas en que habitaban miles y miles de personas. Pensaba: «el antimonio, el fuego», pero la reverberación era tan lejana, nos costaba tanta sangre y dolor aquella ciudad alucinante, que generalmente miraba la aureola roja de la muerte como cuando era niño, en el campo, miraba las lejanas girándulas de fuego de la fiesta de San Calógero: un luminoso y lejano juego de la noche.

En suma, semejante salto espacio-temporal no es gestionable ante litteram por El teatro de la memoria (1981), que es "teatro de la verdad», como destaca Di Grado, ${ }^{143}$ pero también, según el propio Sciascia, "pura diversión", "auténtica vacación», que, a caballo de los tristes ańos setenta y ochenta, son el necesario "contrapunto de una actividad para nada divertida en que estoy empeñado desde hace más de dos años». ${ }^{144}$

Es claro que en ese salto, en esa oscilación, siempre hay más compromiso que vacación o "excursión», consecuencias ambas de una fuga acrítica de la realidad que, como es sabido, Merleau-Ponty estigmatiza en $\mathrm{Ha}$ habido una guerra, a propósito de las vacaciones del 39 de los franceses (y de tantos otros).

Hay mucho olor a pólvora en esa oscilación entre extremos históricos e íntimos, siniestros y a la vez excitantes, del personaje adulto/Madrid bombardeada y del personaje niño/fiesta de San Calógero, y también de España, la guerra, Sicilia, la fiesta. Todo dentro de esa mencionada "continuidad» que Italo Calvino —en carta de 26 de octubre de 1964, ${ }^{145}$ cercana a El antimonio y, además, a El archivo de Egipto (1963) - evoca y traza a su modo en aquella sciasciana «serie de cargas explosivas bajo los pilares del pobre iluminismo, comparadas con las cuales las mías son sim-

143 Di Grado, «Il teatro della memoria (e della verità) di Leonardo Sciascia», Siculorum Gymnasium, 1, 2003, pp. 57-62.

144 Así concluye la nota final de Sciascia, Il teatro della memoria, Einaudi, Turín, 1981, p. 77 (El teatro de la memoria, trad. Eugenio Gallego, Alianza, Madrid, 1986).

145 Cfr. de nuevo la carta de Calvino, reproducida en Tedesco, "Avevo la Spagna nel cuore": Sciascia, la Sicilia, la Spagna», cit., p. 14. 
ples fuegos de artificio». Es como si sugiriera, al menos para nosotros, que en Sciascia incluso los fuegos artificiales —acaso los inspirados, más o menos metáforicamente, en Calvino, entre El sendero de los nidos de araña (1947) y El barón rampante (1957), entre la guerra civil y las luces- son cargas explosivas o que, de todas maneras, se puede partir de tales fuegos para llegar a una "serie de cargas explosivas», precursoras, en el seno de los "poderes del horror", ${ }^{146}$ de incendios nocturnos y oscilaciones más o menos ambiguas y espectaculares; de nuevo, una reminiscencia dostoievskiana.

Leamos una página de "La fiesta», en la última parte de Los demonios (1873) de Dostoievski:

Un gran fuego nocturno tiene siempre un efecto excitante y divertido: en ello se basan los fuegos de artificio, pero en ese caso el fuego se dispone en líneas regulares, elegantes y, siendo perfectamente inocuo, crea una impresión de alegría y ligereza, como la que deja una copa de champán. Bien distinto es un verdadero incendio: aquí el horror y, se quiera o no, un cierto sentido del propio peligro, unido a ese efecto placentero que produce el fuego nocturno, suscitan en el espectador (no, claro, en las víctimas del incendio) una especie de sacudida del cerebro, casi un estímulo de sus propios instintos de destrucción que, ay, anidan en cada alma, incluso en la del más dócil y hogareño consejero honorario... Esta siniestra sensación es casi siempre embriagadora. «No sé yo si se puede contemplar un incendio sin cierto placer»: palabras textuales que me dijo un día Stepan Trofimovich cuando volvía a casa de un incendio nocturno con el que se dio de bruces y estando aún bajo la primera impresión del espectáculo. Se comprende que la misma persona que ama los incendios nocturnos se arrojaría al fuego para salvar a un nińo o a una vieja envueltos en llamas; pero esa es otra cuestión. ${ }^{147}$

146 Cfr. Julia Kristeva, Pouvoirs de l'horreur, col. Tel Quel, Seuil, París, 1980 y col. Points, 1983, pp. 25-27 (Poderes de la perversión, trad. Nicolás Rosa y Viviana Ackerman, Siglo XXI, México, 1989).

147 Dostoievski, I demoni, Istituto Geografico De Agostini, Novara, 1983, vol. II, p. 474 (Los demonios, trad. Juan López-Morillas, Alianza, Madrid, 1984). Una novela cuya parábola - generada por la crónica negra y la voluntad de sustraerse a la autoridad del jefe, intolerante terrorista - puede aflorar metafóricamente en el relato de Sciascia. Entre otras cosas, y por una curiosa coincidencia, se origina en un hecho ocurrido en Moscú en 1869 del que Dostoievski tuvo noticia en Dresde, futura ciudad herida, destinada a ser engullida por las llamas. Aquella Dresde evocada por otro escritor visionario de la generación de Sciascia, Kurt Vonnegut (nacido en 1922), en su Slaughterhouse-Five, de 1969 (Matadero cinco, trad. Margarita García, Anagrama, Barcelona, 1987). En cuanto a los terroristas rusos de la época de Dostoievski, no se puede dejar de pensar en un crítico de la cultura apenas más joven, Hans Magnus Enzensberger (nacido en 1929), cuyo ensayo Politik und verbrechen, de 1964, apela también a El hombre rebelde de Camus. He consultado la ver- 
Volveremos sobre la "otra cuestión», realmente otra. Ahora hay que insistir en el hecho de que el fuego, en El antimonio, parece convertirse lisa y llanamente en la memoria individual del protagonista, antes de ser - de fundirse o completarse con - la memoria colectiva de la guerra, de Madrid y las demás ciudades heridas (también del regreso, y de la Españamina de azufre). No es casual que el «ex minero de Regalpetra» se marche como voluntario a la Guerra de España después de haber corrido el riesgo de morir abrasado por el grisú — «los mineros del azufre de mi pueblo llaman antimonio al grisú»- ${ }^{148}$ y sea "hipersensible a todo lo que se parezca al fuego». ${ }^{149}$

Esta hipersensibilidad, como el miedo íntimamente ligado a ella, no es un límite - lo veremos en seguida, alejándonos un poco del fragmento citado, cuyo análisis retomaremos-; sería otra clave esencial de lectura de la mutación que experimenta el personaje sciasciano, en línea con una célebre afirmación de Gaston Bachelard, más propia de la ensoñación que de la historia:

Si todo lo que cambia lentamente se explica por la vida, todo lo que cambia rápidamente se explica por el fuego. ${ }^{150}$

Desde luego, en el trágico episodio de la mina —rápidamente evocado a pocas páginas del comienzo del relato, del que parece un complemento- encontramos una vez más el agua, contrafigura del fuego, pero que no interviene en la historia y relega el episodio más bien a la alucinación, al sueño, la ensoñación, incluso a la ilusión cinematográfica (quizás, lo mismo que el episodio, derivada de Malraux y La esperanza, texto de 1937 muy querido por Sciascia, que lo sitúa entre las mejores novelas del siglo $\mathrm{XX}^{151}$ y lo recuerda, en relación con la guerra civil española, a continuación de los libros de Orwell y Bernanos en la lista de 1981 citada en el epígrafe 3):

sión francesa, a la que me remito: Enzensberger, "Les rêveurs de l'absolu», en Politique et crime, Gallimard, París, 1967, pp. 236-300 (y 328-329); léase también la segunda parte, dedicada a "Las bellas almas del Terror», pp. 271-300 (Politica y delito, trad. Lucas Sala, Anagrama, Barcelona, 1987).

148 Sciascia, L'antimonio, cit., p. 166.

149 Traina, Leonardo Sciascia, cit., p. 230.

150 Bachelard, La Psychanalyse du feu, cit., p. 23.

151 Traina, Leonardo Sciascia, cit., p. 227. Cfr. también Sciascia, "Com’era la Spagna», L'Ora, 20 de agosto de 1966, luego en Quaderno, introd. Vincenzo Consolo, nota de Mario 
Mi tío advirtió de nuevo: "Aflojad las lámparas de acetileno», y un minuto más tarde, del fondo de la galería, llegó un rugido de fuego: como había visto en el cinematógrafo el agua precipitándose de unas compuertas abiertas, así el fuego se nos vino encima gritando. Pero esto lo pienso ahora; no estoy seguro de que fuese exactamente así. Veía el fuego encima y no entendía nada; mi tío gritaba « $\mathrm{El}$ antimonio!» y me arrastraba, y yo corría ya como en un sueño. ${ }^{152}$

El miedo del ex minero tiene también un triste precedente en la familia («llevan a casa a mi padre, abrasado por el antimonio»; «siempre había tenido pavor del antimonio porque sabía que quemaba las vísceras: así había muerto mi padre»). ${ }^{153}$ Un precedente que pesa, una herencia de horror y miedo que tiende, sobre todo, a identificar la figura del padre con la mina de azufre - y con la muerte que esta procura a través del antimonio, del fuego-, absolutizándola hasta casi borrar sus rasgos subjetivos, intelectuales, ideológicos, como si no hubiese existido como hombre o como sujeto, ni siquiera político.

Mi padre murió en el 26, tenía yo dieciséis años. El pensamiento de su vida y de cómo había muerto no me dejaba nunca, pero había olvidado que había sido socialista. Al escuchar el himno de los trabajadores veía a mi padre cogiéndome de la mano [...] Era una música hermosa; llegaba un momento en que parecía desgarrar los nubarrones, cuando la letra decía: «Sobre la bandera libre brilla el sol del porvenir». Abría, realmente, la esperanza.

Pero ¿qué era el socialismo? Una buena bandera, claro, como decía mi padre (justicia, igualdad), pero [...].

Pero el socialismo debía ser también como la religión, una gran olla en la que hierven muchas cosas, y cada uno pone dentro un hueso para hacer un caldo a su gusto. Para mí era solo el recuerdo de mi padre, su fe, el modo en que murió, y yo que había arriesgado una muerte parecida, y dońa Maria Grazia, que decía de mí: "Tiene las ideas torcidas de su padre», mientras que yo no tenía ideas ni rectas ni torcidas, solo un dulce recuerdo de mi padre y la pena de cómo había muerto, y mucho miedo del antimonio, y un poco de esperanza en la justicia. ${ }^{154}$

Farinella, Nuova Editrice Meridionale, Palermo, 1991, p. 168: «Barcelona, hotel Colón: trigésimo aniversario del Alzamiento. Recién llegado, al asomarme al balcón, me doy cuenta de que el Colón del que habla Malraux en las primeras páginas de La esperanza (estupendas páginas, grandísimo libro: tal vez el más grande que se haya escrito en estos treinta ańos) tenía que estar situado en otra parte de la ciudad. Esta avenida de la catedral, que es una plaza con árboles y palomas, no puede ser aquella en que el 19 de julio de 1936, hace justo treinta ańos, obreros y empleados se lanzaron vana, sangrientamente al asalto del hotel en que militares y fascistas se habían atrincherado. He cometido el error de no traerme el libro de Malraux, y no tengo un preciso recuerdo de cómo describe el lugar y los hechos».

152 Sciascia, L'antimonio, cit., p. 179.

153 Ib., pp. 174 y 179.

154 Ib., pp. 184-185. 
El miedo al antimonio, en definitiva, reajusta el disco duro del mundo, del socialismo, de la religión, y no hace de ellos — comenzando por el padre, la víctima, y por un elogio incondicional de la memoriaaltares más o menos solares y futuristas de otros ismos ideológicos (fascismo italiano, español...), apuntando en cambio a la «justicia». A este propósito será útil pensar en algunas páginas de Puertas abiertas (1987), título que recupera, amplifica - puertas abiertas de los partidos a fáciles y oportunistas cruces ideológicos, puertas abiertas de los amigos, «auténticas puertas abiertas de la ciudad»—155 y desacraliza en forma de "puertas cerradas» esa falsa, consoladora y "suprema metáfora del orden, la seguridad y la confianza» que se esconde en el clásico estribillo «Dormimos con las puertas abiertas»:

«Dormimos con las puertas abiertas». Pero era el sueño de las puertas abiertas, al que correspondían en la realidad cotidiana, cuando estamos despiertos, especialmente aquellos a quienes les gusta permanecer despiertos y escrutar, comprender y juzgar, tantas puertas cerradas. ${ }^{156}$

Vuelve a surgir la oposición «dormir/permanecer despierto» de $E l$ antimonio, típica de Sciascia, pero en Puertas abiertas se origina de nuevo en la segunda mitad de los años treinta, los de la guerra civil española, no casualmente traída en causa en las primeras y últimas páginas de esta novela breve. Al comienzo del proceso, al que se consagra el libro, la Guerra de España es evocada significativamente gracias al arma del delito, con el que se relaciona:

Venía luego a turbarle [el juez] visceralmente, con un horror que sentía en la carne además de en la mente, el puñal. [...]. Posado sobre un trozo de periódico del que el juez, desde lo alto de su escańo, leía el mayor de los titulares: El Duce se dirige a Franco en el primer aniversario de su designación como Jefe del Estado Español [...]. ${ }^{157}$

En el penúltimo capítulo, casi al final del coloquio del juez con el miembro del jurado — «el amigo» que comparte la «línea» procesal del juez y «hace un gesto contra la pena de muerte»— y su compañera, la francesa «Simone», reaflora la importancia de la guerra civil española. Note-

155 Sciascia, Opere 1984-1989, cit., pp. 333 y 355.

156 Ib., p. 344.

157 Ib., pp. 350-351. 
mos el rápido crescendo en que intervienen los tres personajes, tan fuerte e intenso en sus afirmaciones, que el autor desvía las frases del amigo hacia el protectorado de los ingleses y el terrorismo de los judíos en Palestina, como si trajese provocadores ecos de la propaganda nazi-fascista de la época y de la palpitante actualidad de la intifada, para luego resaltar la distancia del juez y de Simone respecto a la aprensión del amigo «sobre algunas noticias que la Guerra de España dejaba al margen» y diluir el diálogo en una charla más liviana y literaria, que implica también al «fascismo». Fascismo que, no casualmente, «aparece lejos» y va convirtiéndose, sin la concreción de la guerra civil española, en un punto, en un signo de «un mapa imaginario de la estupidez humana»:

—En este momento — dijo Simone- los españoles solo desean matarse unos a otros.

—Con el consuelo espiritual de Léon Blum — dijo el juez. Simone.

— Solamente espiritual, y al bando que debería ser el suyo — precisó

-El socialista, el stendhaliano Blum: y sale con la mascarada de la no intervención - dijo el amigo-. Mussolini manda telegramas de congratulación a los generales italianos que, con tropas italianas, conquistan ciudades españolas, y Blum, impasible, sigue hablando de no intervenir en España como si se lo creyese...

- A menos que no se quiera admitir que lo ha entendido Mussolini —dijo el juez-, nadie entiende que la Guerra de España es la piedra de toque de la amenaza que se cierne sobre el mundo.

- Y a menos que no se quiera admitir que lo ha entendido Mussolini, con aquella bufonada de la espada del islam, ni ninguno de los directamente interesados, lo que pasa en Tel Aviv me preocupa mucho — dijo el amigo.

[...]

Esa aprensión sobre algunas noticias que la Guerra de España dejaba al margen (el terrorismo de los judíos que querían fundar un Estado, el modo en que los ingleses gestionaban su protectorado en Palestina) parecía a Simone y al juez completamente excesiva, y hacer de ello un tema de discusión, algo un tanto obsesivo. [...]. Así que, llegados a cierto punto, la discusión sobre ese argumento se fue apagando. Siguieron hablando, con ligereza, con brío, de Francia, de algunos escritores, de libros. Y del fascismo. Pero hablando de ese modo, el fascismo aparecía lejos, como un signo en un mapa imginario de la estupidez humana. ${ }^{158}$

Más allá de la relevante presencia de la guerra civil española, una suerte de trágico y especular telón de fondo del proceso, lo que nos interesa subrayar en Puertas abiertas no se refiere directamente a la Guerra de Espa-

158 Ib., p. 394. 
ña, sino a la figura del padre en El antimonio. Considérese el hecho de que se remita a la memoria -íntima pero también colectiva: «memoria de los italianos que tenían memoria»— otra muerte trágica de los ańos veinte, en concreto de 1924, la del diputado Giacomo Matteotti, "considerado, entre los opositores al fascismo, el más implacable no porque hablase en nombre del socialismo, en aquel momento una puerta abierta por la que se entraba y se salía sin trabas, sino porque hablaba en nombre del derecho. Del derecho penal». ${ }^{159}$

Podríamos sugerir, con Horkheimer, que el miedo — en cuanto «objeto de reflexión»— recupera el recuerdo del padre, de aquel sujeto, «verdadero individuo singular» en su vida de minero, por encima del socialismo y de las «ideas rectas o torcidas». A las cuales se sobreponen precisamente la «pena», el «miedo»y «un poco de esperanza en la justicia». Elementos estos que nos llevan a pensar en lo que anotaba Horkheimer en los años 1961-62 en sus Apuntes (1974) —Notizen 1950 bis 1969-a propósito del «concepto de individuo singular»: ${ }^{60}$

En la medida en que [al individuo singular] le importa exclusivamente él mismo, es un elemento de la masa, y el conformismo es su comportamiento adecuado. La gente se reconoce incluso en el jefe brutal que ordena un asesinato [...]. Por el contrario, el verdadero individuo singular se reconoce unido a los demás no tanto en la persecución de intereses inmediatos como en la miseria de los excluidos, los enfermos, los perseguidos, los condenados, los proscritos, cada uno de los cuales es «singular» en un sentido doloroso y desesperado. Pensando en ellos, él siente y actúa —en última instancia, obedeciendo al propio miedo, que por lo demás puede ser tan poderoso como para inducirle a consagrarse a ellos, compartiendo su destino- - El miedo no es una noble aspiración a la buena vida y al poder: también puede llevar al conformismo; pero, si se torna objeto de reflexión, puede incluso vencer al conformismo y fundar esa solidaridad sin la cual el individuo no es imaginable.

En tal sentido, El antimonio es también una travesía del miedo, miedo al «asesinato no solo impune, sino premiado [...] realizado con gratitud y gratificación por parte del Estado», ${ }^{161}$ como se lee en Puertas abiertas. El antimonio es, pues, una travesía del miedo a partir del riesgo de confor-

159 Ib., pp. 331 y 333.

160 Max Horkheimer, Taccuini 1950-1969, Marietti, Génova, 1988, p. 174 (Apuntes 1950-1969, trad. León Mames, Monte Ávila, Caracas, 1976). Cfr. Marcuse, prólogo (1964) a Cultura e società, cit., pp. XVIII- XXI.

161 Sciascia, Opere 1984-1989, cit., p. 336. 
mismo y no de una solidaridad acrítica, que se da por descontada y se puede rastrear acaso en el horizonte radiante del socialismo o de la religión: la fuga de la mina de azufre puede resultar acrítica, pero la solidaridad final del personaje es fruto precisamente de la crítica, de la crítica social. Aun cuando no es ciertamente fácil —ni siquiera dentro de esa tradición italiana representada por El imperio en provincias (1945) y Michele en Guadalajara, de Francesco Jovine- ${ }^{162}$ elegir, como hace Sciascia, el punto de vista de las tropas enviadas por Mussolini a España y entrar luego de lleno, legítimamente, en la mitografía antifascista (tampoco es fácil apostar históricamente por el repatriado, primero, y después por el juez, quien, a pesar de sentarse en su escaño, parece prolongar idealmente la parábola del repatriado y la rebeldía).

El recuerdo del padre, la "pena» (también la pena gritada por las mujeres de Madrid bajo las bombas), el «miedo" y ese "poco de esperanza en la justicia» son de hecho recuperados gracias a la conformista decisión de ofrecerse voluntario para la Guerra de España ( No he hecho la guerra de África, pero esta quiero hacerla»), que huele a exorcismo («-No está claro que vayamos a España... - Hasta al infierno - dije») y, como sugeríamos arriba, a fuga acrítica y no muy meditada («la mina me daba miedo; en comparación, la guerra en España me parecía una excursión»), también porque encontrar fuego en una guerra es realmente fácil. El miedo al antimonio, justamente, se reconduce en seguida al miedo al lanzallamas:

Al día siguiente [del accidente] me sentía viejo, con cien años, y decidí que nunca más volvería a la mina. Sabía que había una guerra en España; muchos habían ido a la de África y habían hecho dinero, solo uno de mi pueblo había muerto allí. Además, morir a la luz del sol no me daba miedo (en toda la guerra de Espańa no he tenido miedo a la muerte; pero sudaba con solo pensar en el lanzallamas). ${ }^{163}$

Frente a este complejo cruce de datos históricos y simbólicos, la crítica, sin caer en la tentación de hallar aquí un trozo de autobiografía, ha recordado en diversas ocasiones (Ambroise, ${ }^{164}$ por ejemplo) algunos deta-

162 Volveremos sobre estas novelas en el capítulo 2.

163 Sciascia, L'antimonio, cit., p. 179.

164 Ambroise, "Il libro nel libro", cit., pp. 40-41, y su Invito alla lettura di Leonardo Sciascia, cit., pp. 13-16 y 95. 
lles de la vida del escritor: «Sciascia no ha sido minero del azufre, pero su abuelo empezó a trabajar como aprendiz [caruso, en dialecto siciliano], su padre era un empleado administrativo de la mina y su hermano, perito de minas, se suicidó en la mina azufrera de Assoro en 1948, donde también estaba el padre».

Detalles ineludibles pero que no hay que llevar sin más a una autobiografía "antimoniesca». A ellos siguen los del oficio, es decir, los libros leídos, dedicados a la guerra civil espańola, especialmente las novelas, y entre estas, las más amadas, así la varias veces citada La esperanza (1937) de Malraux, un episodio de la cual —lo sugiere Ambroise, atendiendo seguramente a una nota del propio Sciascia - «ha sido reescrito de manera que aparezca la misma escena pero vivida por los combatientes del otro bando [los fascistas]». ${ }^{165}$

Obviamente, tal reescritura va mucho más allá de una transposición de partes combatientes. Por lo demás, el texto de Malraux ofrece al universo del escritor siciliano algo más que una escena — casi un imaginario ${ }^{166}$

165 Ambroise, "Cronologia», en Sciascia, Opere 1956-1971, cit., p. LVI. Pienso en Sciascia, epílogo a Les Oncles de Sicile, Denoël, París, 1967 y Gallimard, París, 2002, p. 286: «Debo añadir otra breve observación al tema del relato El antimonio, que fue incorporada en la edición de 1960: la escribí recogiendo testimonios y recuerdos de campesinos y mineros del azufre de mi pueblo (Racalmuto, en la provincia de Agrigento) que habían combatido durante la Guerra de España al lado de los fascistas, pero fue la lectura de $L a$ esperanza lo que me dio la idea de escribirla. Por tanto, hay que entender un determinado fragmento de mi relato como un homenaje a Malraux: corresponde precisamente a la página 804 de las Novelas de Malraux, editadas en la Bibliothèque de la Pléiade». Cfr. André Malraux, Romans. Les Conquérants. La Condition humaine. L'Espoir, Gallimard, París, 1947 y 1955, p. 804, y L'Espoir, col. Folio, Gallimard, París, 1972 y 1989, p. 519: «Los garibaldinos atacaban el edificio por un flanco, los franco-belgas por otro [...]. Siry vio correr a cinco camaradas, caer a cuatro, la cabeza del camarada a su derecha que desaparecía, las balas excavando la tierra por todas partes, un tipo que exhibía algo y era una mano sangrante. Antes de darse cuenta de que, desaparecido el árbol, estaba bajo el fuego de las ventanas del edificio Ibarra, Siry [...], a menudo saludado por el sentido común, se echó cuerpo a tierra». En L'antimonio, pp. 219-220, se lee: «Tras la primera avanzada, nuestra sección se había detenido a causa de una ametralladora que nos disparaba con precisión [...]. Yo estaba detrás del tronco de un árbol [...] con la cabeza a salvo, no creía que la ametralladora pudiese darme; estaba tumbado boca abajo y alargué la mano izquierda, que se me había entumecido, fuera del refugio [...]. Lo que se siente al verse de golpe una mano sangrante, una mano que ya no es mano, es como si uno fuera arrojado fuera de sí mismo».

166 Si se quiere un ejemplo, al que regresaremos al comienzo del siguiente capítulo, trayendo a colación a Dos Passos, cfr. Malraux, L’Espoir, cit., p. 43: «- ¿Y Cristo? —Un 
que vuelve- en que inspirarse y con la que poner término (la pérdida de la mano) a la Guerra de España en El antimonio. El comienzo contendría un similar homenaje a La esperanza: describe, como sabemos, el asedio a una iglesia — desde cuyo campanario disparan los republicanos - por parte de los fascistas, obligados a apostarse en el cementerio:

Disparaban desde el campanario: dependiendo de nuestros movimientos, ráfagas breves de ametralladora o precisos disparos de fusil. El pueblo era solo una calle sin salida, casas bajas y blancas, y en el fondo una iglesia con una tosca fachada de arenisca, dos rampas de escalones y una espadaña de tres arcos. Desde el campanario disparaban. Ordenaron a nuestra compañía que fuese al otro lado del pueblo, detrás de la iglesia; pero detrás de la iglesia había un precipicio de roca que parecía cortado a pico, tan liso y vertical era, y el capitán decidió que nos apostáramos en el cementerio, sobre una altura cercana, al nivel del tejado de la iglesia y el campanario. Cuando se apercibieron, comenzaron a enviar ráfagas sobre las tumbas.

Hacía una hora que estaba tras el cipo de una tumba, de rodillas, y estregaba mi cara contra el mármol para hallar algún refrigerio. Sentía que se freía mi cabeza dentro del casco ardiente; vibraba el aire, a la llamarada del sol, como si estuviera en la boca de un horno. ${ }^{167}$

Volveremos luego a este pasaje, en particular a las últimas frases. Abramos ahora La esperanza por el primer capítulo de la segunda sección («Ejercicio del apocalipsis») de la primera parte («La ilusión lírica»), donde encontramos una escena de batalla muy parecida pero al revés, con los republicanos, que sitian el Alcázar, intentando un ataque a través del cementerio. Similares son los sentimientos, las emociones, las posturas de los personajes y los elementos destacados del paisaje: «el miedo [...], la inmovilidad [...], el duro sol [...], el cementerio». ${ }^{168}$

Pero lo que en este capítulo no podía dejar de llamar la atención de Sciascia es la descripción de lo que pasa poco después de la aparición de un «lance-flammes», en la que descuella una frase sciasciana y antimoniesca o, mejor aún, bachelardiana en cierto modo (pienso, como es obvio, en su Psicoanálisis del fuego): "La guerra nada tenía que ver con este combate de los hombres contra un elemento»:

anarquista que ha triunfado. El único», y Sciascia, L'antimonio, cit., p. 210: «Y los anarquistas $[. .$.$] cada uno de ellos se sentía un poco Jesucristo, y veía el mundo redimido con$ su propia sangre».

167 Sciascia, L'antimonio, cit., p. 167.

168 Malraux, L'Espoir, cit., p. 153. 
Una docena de milicianos llegó corriendo, entre ellos el Negus.

- ¡Ahí están, con un lanzallamas!

Entre pasillos y escaleras, Hernández, García, el Negus, Mercery y los milicianos habían alcanzado un sótano con una alta bóveda, llena de humo y detonaciones, abierta ante ellos por un amplio pasillo subterráneo donde el humo se volvía rojo. Pasaron unos milicianos corriendo, con cubos llenos de agua en las manos o entre los brazos. Apenas llegaba el estruendo del combate exterior $[\ldots]$. Los fascistas estaban en el pasillo.

El chorro del lanzallamas, fosforescente en la oscuridad, llegaba hasta allí y rociaba el techo, la pared de enfrente y el pavimento, con un movimiento bastante lento, como si el fascista que sostenía el tubo hubiera elevado sin cesar una larga columna de gasolina. [...] La guerra nada tenía que ver con este combate de los hombres contra un elemento. El riego de gasolina avanzaba, todos los milicianos excitados con el chasquido del agua en la pared, el crepitar del vapor y la tos infernal de gargantas atenazadas por el acre olor del petróleo y el atroz silbido mórbido del tubo. El haz de gasolina crepitante avanzaba paso a paso, y el frenesí de los milicianos se veía multiplicado por las llamas azulencas y convulsivas que mandaban a danzar sobre los muros racimos de sombras enloquecidas, todo un desencadenarse de fantasmas que se estiraban alrededor de la locura de los vivos. Y los hombres contaban menos que esas locas sombras, menos que esa niebla sofocante que transformaba todo en siluetas, menos que esa crepitación salvaje de las llamas y el agua, menos que los pequeños lamentos aullados por una persona abrasada.

$[\ldots]$

El fascista dio un salto oblicuo para llevar el chorro de llamas hasta el Negus, tocaba ya su pecho. El Negus disparó. El tubo inflamado cayó con un ruido en el suelo de piedra, lanzando todas las sombras al techo: el fascista vaciló bajo la luz que proyectaba el tubo caído, su rostro iluminado por abajo - un oficial bastante mayor-, de lleno en la fosforescente claridad de la gasolina. Al final se deslizó a lo largo del Negus, con un ralentí de cine, la cabeza en el chorro de llamas, que, hirviente, la despejó como si le diera una patada. El Negus giró entonces el tubo: toda la estancia desapareció en una oscuridad total, mientras surgía el sótano lleno de nubes por entre las que huían unas sombras. ${ }^{169}$

«La guerra nada tenía que ver con este combate de los hombres contra un elemento"; y lo que sigue, hasta el final del párrafo, puede ofrecer, en síntesis, esa clave de lectura adicional que vincula fuego, miedo y memoria, y puede tal vez situarse en el origen de todo el relato de Sciascia y no solo de una «escena». Porque, como decíamos, no es tan difícil encontrar el fuego en una guerra, más allá de la personal variación sciasciana, Sicilia en Espańa, y la supuesta ingenuidad del personaje — parece caer, proverbialmente, de la «sartén» de la mina al «fuego» de la guerra— no 
tiene como fin encajar simple y llanamente tales coordenadas en el texto. Lo impide, sobre todo, la ética sciasciana del lenguaje, que en párrafos precedentes hemos tratado de poner en evidencia; el resto lo hace el oficio, aun cuando en el origen existan fuentes con las cuales, ciertamente, es duro ajustar cuentas, en términos éticos y artísticos.

A este propósito, y a título de ejemplo, conviene prestar atención al menos a una solución retórica mediante la cual el oficio del escritor siciliano opera desde la primera página, actuando no solo sobre la trama, sino también en un nivel microtextual, con un juego de aliteraciones y a la vez de oxímoron, que disimula y revela la no fácil tentativa de fuga del protagonista del fuego de la mina, de Sicilia y de su misma vida: de la memoria que de ella tiene a través del fuego:

Hacía una hora que estaba tras el cipo de una tumba, de rodillas, y estregaba mi cara contra el mármol para hallar algún refrigerio. Sentía que se freía [friggere] mi cabeza dentro del casco ardiente; vibraba el aire, a la llamarada del sol, como si estuviera en la boca de un horno. ${ }^{170}$

En esa suerte de "zona fronteriza», podríamos decir con Victor Brombert, que es el cipo de la tumba, donde el yo se enfrenta con su soledad (y sus fantasmas de fuego) en un régimen de segregación, alejado de la comunidad de mariposas de Madrid, de «un aprendizaje de la comunión», ${ }^{171}$ la España de la guerra civil no aporta ningún refrigerio, y el soldado ex minero siente que se frie. Ese freírse elegido en relación con refrigerio pero que marca también una distancia entre la soledad o, si se prefiere, entre la prisión de la mina reencontrada en la guerra, y la comunidad de la guerra, expresada por el arder del largo fragmento citado más arriba y extendida, insisteremos luego, más allá del asedio y de su doble prisión, hasta unir a sitiadores y sitiados: una unión donde Sicilia se reencuentra con España mediante la imagen de la «ampliación» obrada por el «Padre Eterno [...] con uno de esos aparatos que venden en las ferias». Imagen esta que, por supuesto, no deja indiferentes a los lectores que conocen a Sciascia, un escritor que no se casa nunca, salvo en apariencia, con la facilidad expositiva, la cual tiende seguramente a una banal espectacularización.

170 Sciascia, L'antimonio, cit., p. 167 (los subrayados son nuestros).

171 Brombert, "La zona-frontiera», en La prigione romantica. Saggio sull'immaginario (1975), Il Mulino, Bolonia, 1991, pp. 245-255; la cita, en p. 246. 
A tal facilidad se confía en cambio Aldo Florio cuando, con la complicidad de Bruno di Geronimo y Fulvio Gicca-Palli, intenta en Una vita venduta (1976) una libre adaptación cinematográfica de El antimonio, con escasos resultados, sustancialmente en la primera mitad, la más fiel al texto de Sciascia, autor cortejado por el cine y que con el cine se divierte pero que, en sus libros, como sugiere Madrignani, «no se abandona a descripciones hollywoodianas». ${ }^{172}$

No son las descripciones de Sciascia, ciertamente, hollywoodianas, sobre todo desde un punto de vista eminentemente literario (de crítico literario), y no lo son, al menos, en el sentido de que no imponen su absolutismo mediante espectacularizaciones forzadas y, cada vez más, fin en sí mismas, como sucede en el conocido y deprimente lenguaje cinematográfico norteamericano. El cual, de todas maneras, se sitúa fuera de la vieja y acogedora cuba de Hollywood, que para Sciascia, en cambio, producía buen vino, como reconoce sin arrogancia académica Antonio Di Grado: ${ }^{173}$

Amaba Hollywood, es decir, la tradición comunicativa y cómplice del «cine-cine», del sólido artesanado no contaminado de prejuicios y neurosis de autor.

Dicho esto, no podemos compartir plenamente las radicales ideas que se leen en la apertura de "El cine de Leonardo Sciascia», de Emiliano Morreale, cuyas afirmaciones parecen cubrir todo Sciascia y obedecen, digamos, al conocimiento de un corpus traducido, esto es, más fílmico que narrativo, y a un punto de vista eminentemente cinematográfico (de crítico de cine).

La referencia, bastante frecuente, al estilo «cinematográfico» de las novelas de Sciascia me parece más bien arbitraria. En realidad, su escritura, tan ensayística e irónica incluso en la narrativa, no parece muy asimilable a la escritura "cinematográfica» de los norteamericanos o de otros sicilianos de la nueva generación, muy distintos entre sí (Alajmo, Conoscenti), o al caso ejemplar de Camilleri. ${ }^{174}$

Una decena de páginas después, sin embargo, concede que «algunos icásticos pasajes del relato La tía de América» — texto que abre la primera

172 Madrignani, "Cassola e altri "buoni maestri”", cit., p. 98.

173 Di Grado, «Sciascia, il cinema e (fra l'altro) l'Europa: (bianco e) nero su nero», cit., pp. 67-69.

174 Morreale, «Il cinema di Leonardo Sciascia», Segno, 209, 1999, p. 185. 
edición de Los tíos de Sicilia (1958)— son «sí, cinematográficos» e incluso, por lo que parece, fuente de inspiración afectuosa (y no solo) para Giuseppe Tornatore en Nuevo Cinema Paradiso (1989) —última película vista, apreciada y comentada por Sciascia-y en La pantalla de tres picos (1996), cuya sección conclusiva está íntegramente dedicada al escritor siciliano, y no es casual. ${ }^{175}$

Es difícil, por tanto, extraer consideraciones generales y decir -especialmente en relación con el primer Sciascia- qué fragmentos narrativos son más o menos icásticos o retratan la realidad por medio de imágenes, y con evidencia representativa, entre la tradición literaria y el impacto cinematográfico. En otras palabras, qué fragmentos narrativos son más o menos descriptivos y más o menos traducibles en «cine-cine», incluyendo los amados modos hollywoodianos.

Acaso resulte más fácil decir, con Morreale y sobre todo con Ambroise, ${ }^{176}$ que el narrador siciliano entra en una «problemática de la visión» donde "la invención de los hermanos Lumière permite realizar el deseo imposible, de manera mucho más inmediata que la literatura, [...] de ser otro». ${ }^{177}$ Desde esta perspectiva, el fragmento de las mariposas, cerrado, bien identificable y claramente icástico, no solo parece enmarcado de manera cinematográfica, sino incluso enunciar el fantasma de un cine - «Mientras estaba sentado [...] un luminoso y lejano juego de la noche»— y el deseo imposible realizado por el cine: «Mientras estaba sentado [...] Dábamos vueltas en torno a Madrid, como las mariposas, de noche [...]»

Es más, el narrador siciliano entra en una «problemática de la visión» y en una "constelación de lo "visible" d donde también juegan, con pleno derecho, la fotografía y la pintura, no solo el cine y la literatura. Y esto gracias al hecho de que Sciascia es, "en cierto modo, "hijo del mudo"» y de la "cinematográfica» caverna platónica que, en tal sentido — como se sabe-

175 Ib., p. 193. Pero cfr. Sciascia, "C'era una volta il cinema», en Opere 1984-1989, cit., pp. 635-641, y Vincenzo Consolo, «Dal buio, la vita» (1990), en Di qua dal faro, Mondadori, Milán, 1999, pp. 203-208 (A este lado del faro, trad. Miguel Ángel Cuevas, Parténope, Valencia, 2008).

176 Ambroise, "Un primo sguardo sulla problematica del vedere in Leonardo Sciascia», en Sebastiano Gesù (ed.), Leonardo Sciascia, Giuseppe Maimone Editore, Catania, 1992, pp. 23-30.

177 Ib., p. 24. 
fue su madrina, ofreciéndole en consecuencia, respecto al cine (y a esa literatura que también es cine), una «actitud de fondo [...] teóricofilosófica», ${ }^{178}$ la misma que hemos tratado de presentar y abordar en el primer párrafo, en toda su complejidad, y que podríamos resumir aquí en los siguientes términos. El héroe-álter ego sciasciano de El antimonio parece experimentar, entre el cine y la literatura, entre el ver y lo visible de un fragmento como el de las mariposas, otro modo de aproximarse a las cosas y a sí mismo. ${ }^{179}$ Esa modalidad narrativa no es hija solo de una "dimensión directoral del relato» ${ }^{180}$ y de un cine al aire libre, sino, además, de una conciencia sobre la que insiste, en 1960, el último Merleau-Ponty en el breve pero densísimo El ojo y el espiritu:

El espacio no es ya aquello [...] que vería un tercero, testigo de mi visión [...], es un espacio contado a partir de mí mismo como punto o grado cero de la espacialidad. Yo no lo veo según su envoltorio exterior; lo veo desde dentro porque estoy englobado en él. Después de todo, el mundo está alrededor de mí, no delante de mí. La luz se presenta así como acción a distancia, no ya reducida a la acción de contacto; en otras palabras, concibe el ser para aquellos que no lo ven. La visión recupera su poder fundamental de manifestar, de mostrar algo más que a ella misma [...], hace falta que tenga su imaginario. ${ }^{181}$

Acordémonos de que el antimonio deja «ciegos» — hay que insistir en este dato-y de cómo Rovatti, lector del último Merleau-Ponty —y de su testamentario El ojo y el espiritu-, hablaba de «situarse como vidente en el interior $[\ldots] \mathrm{y}$, en cualquier caso, a partir de la visibilidad». ${ }^{182}$

El fragmento de las mariposas de Madrid nos puede ayudar a reunir, a medio camino entre la actitud teórico-filosófica y la artesanía literario-cinematográfica, los términos más opuestos y generales de nuestro razona-

178 Morreale, «Il cinema di Leonardo Sciascia», cit., pp. 194-195.

179 Rovatti, Abitare la distanza, cit., p. 37, habla de «un modo de aproximarse (a las cosas, pero también a nosotros mismos) que remonta y resquebraja el modo común de conocer». Cfr., para completar, lo dicho en el epígrafe 1 .

180 Ambroise, "Un primo sguardo sulla problematica del vedere in Leonardo Sciascia», cit., p. 194-195.

181 Merleau-Ponty, L'Oeil et l'Esprit, Gallimard, París, 1964 y col. Folio-Essais, 1985 y 1998, pp. 58-59. Escrito en el verano de 1960, se publica en Art de France, 1, 1961 y luego en un número especial de Les Temps Modernes, 184-185, 1961, pp. 193-227, dedicado a Merleau-Ponty (El ojo y el espiritu, trad. Jorge Romero, Paidós, Barcelona, 1986).

182 Rovatti, Abitare la distanza, cit., p. 57. 
miento, es decir, engagement y divertissement: crítica social, compromiso, por un lado, y, por otro, esa dimensión estética que algunos creen tan desligada y/o fácil de relegar a pretexto metanarrativo, gracias en parte al tono ensayístico e irónico que hace de Sciascia un opinon maker próximo a Eco y un autor de relatos difícilmente traducibles a la pantalla, alejados por tanto del "caso ejemplar de Camilleri». "Campeón de la diversión fácil, incluso facilísima", se dice de Andrea Camilleri, y, como es sabido, se piensa muchas veces en él como heredero de Sciascia; "tristemente», sugiere Giuseppe Traina, pero tal vez en consonancia con esas posiciones críticas que aúnan a Sciascia y Eco. ${ }^{183}$ Ya hemos hablado de tales posiciones, pero todavía hay algo que añadir sobre cómo se «entrecruzan» en El antimonio la actitud teórico-filosófica y la artesanía literario-cinematográfica.

Huyendo de la caverna-mina-galería-cine — «del fondo de la galería llegó un rugido de fuego», ${ }^{184}$ frase que no dejará de recordarnos una secuencia notable de Nuevo Cinema Paradiso, mientras Totò se gira hacia la cabina de proyección-, o bien, huyendo del pueblo y del antimonio que deja "ciegos» (inconscientes, prisioneros), el héroe del relato sciasciano entra en ese "cine» al aire libre que es el mundo, en contacto directo con el sol, ese proyector de la verdad que, como es sabido, quema pero abre los ojos y nos hace libres: libres incluso para competir con el "Padre Eterno» en la descripción, mezcla de Sicilia y España, de una «Castilla desolada y solitaria» y de "una capital en pleno centro»... del "desierto». Todo comprimido en dos páginas, que el lector medio de un texto narrativo se salta ${ }^{185}$ pero que el espectador medio de una película no dejaría de apreciar. Solo en la espectacularidad más evidente, pero no evasiva sino en todo caso lírica, íntima, antropológica, de ese «luminoso y lejano juego de la noche», de aquellas «lejanas girándulas de fuego de la fiesta de san Calógero», tal

183 Cfr. el ataque de Traina, "L'eredità morale e letteraria di Leonardo Sciascia», cit., p. 49: «Para un escritor de fortísima vocación moral como Sciascia, incluso un texto desesperado como El caballero y la muerte puede considerarse "feliz" porque la "felicidad" y la "alegría" de las que hablamos no coinciden, por supuesto, con el diviertimiento fácil. He aquí por qué me parece muy triste, dicho sea de paso, que se proponga muchas veces como heredero de Sciascia precisamente a un escritor como Andrea Camilleri, campeón de la diversión fácil, incluso facilísima».

184 Sciascia, L'antimonio, cit., p. 179.

185 Según "una buena definición empírica» (y provocadora) que encabeza una argumentación teórica, problemática pero ágil, de Pierluigi Pellini, La descrizione, Laterza, Roma-Bari, 1998, p. 7. 
espectador podría quizás tratar de traducir esas páginas en una película, más o menos reciente. Por ejemplo, El Alamein. La línea de fuego (2002), de Enzo Monteleone, donde un soldado italiano de nombre Espańa (interpretado por Luciano Scarpa), arrebatado por el juego de luces de las trazadoras en el cielo africano, exclama: «iPero qué cosas! Parecen los fuegos de la fiesta de mi pueblo».

Respecto al filme de Monteleone, que se centra más en la espera que en la batalla (en cierto modo, la misma espera que en el fragmento sciasciano) y quiere mostrar la vida íntima, incluso lírica, de los soldados y su cita con la historia a través de la toma de conciencia de un joven voluntario (universitario aquí, pero ingenuo y sensible como el minero de El antimonio), el escritor siciliano puede servir de modelo antropológico $\mathrm{y}$, en última instancia, como simple pero no trivial depósito de imágenes, de palabras (también cinematográfico, claro). Partiendo de los fuegos de la fiesta del pueblo que, lo hemos dicho citando a Caillois, se convierten en fuegos de guerra. O bien — acaso con Dino Buzzati y El desierto de los tártaros (1940), pero leído no según los habituales parámetros fantásticospartiendo de ese desierto que, para Yves Panafieu, es «la política de tierra quemada y dolor que el fascismo ha conducido durante años de crecientes amenazas sobre Europa». ${ }^{186}$

No es difícil concluir que, gracias precisamente a estas imágenes y al uso que de ellas hace en El antimonio, Leonardo Sciascia trasciende ese "convencionalismo lingüístico" que podemos reconocer en Winfried Georg Sebald y ciertas descripciones de Dresde o Berlín, pero no en la que el escritor siciliano hace de Madrid, a menos que le queramos convertir en un émulo o descendiente — dicho con el debido respeto al «capitán»— de Emilio Salgari y, quizás, de su Cartago en llamas (1906), o de ese «show» — «Dios, eso parece un espectáculo jodidamente bueno [bloody good show]»- que americaniza y espectaculariza la guerra aérea, desde Dresde hasta Berlín, y sus fuegos de artificio: "Corremos directos al despliegue de fuegos artificiales silenciosos más gigantesco del mundo, y allá vamos, a soltar nuestras bombas sobre Berlín». ${ }^{187}$

186 Cfr. Panafieu, Le mystère Buzzati, Y. P., Liancourt-Saint-Pierre, 1995, p. 54. Lo subrayaba en mi recensión a este libro aparecida en Studi buzzatiani, 1, 1996, pp. 215-218.

187 Cfr. Sebald, Storia naturale della distruzione, cit., pp. 33 y 36 (a propósito del convencionalismo lingüístico). 
Una vida vendida, en cambio, se propone una adaptación que, a pesar de sus medios modestos, persigue la espectacularización del acontecimiento bélico y, precisamente por eso, se abre con una ciudad herida, envuelta aún en fuego, sacudida por bombardeos, atravesada por fusilamientos y representada no por la imaginación del ex minero, sino por el seco comentario de otro formidable personaje ${ }^{188}$ inventado por el escritor: el soldado Ventura (sobreactuado por Enrico Maria Salerno), que en la película es menos simpático, o sea, más mafioso que anarquista, más veleidoso que héroe positivo, libertario y probablemente fugitivo en América, «entre sus parientes del Bronx». ${ }^{189}$ Dice, pues, Ventura-Salerno casi al principio del filme de Aldo Florio: «llaman limpieza a toda esta mierda que hacen tragar a la gente». ${ }^{190}$ Y de «limpieza» habla también el texto sciasciano, al final del párrafo que precede al fragmento cerrado y autónomo de las mariposas de Madrid:

El ejército de Santander quiso, entonces, rendirse a los italianos, y estos garantizaron la vida de los prisioneros. Nos satisfizo que los republicanos vieran que éramos humanos. Fue, sin embargo, una amarga satisfacción, ya que Franco se alzó del reclinatorio y dijo que el general Bastico empezaba a tocarle los c... Claro que no lo dijo así, seguro que su cólera encontró una pulida expresión. Informó a Mussolini, pues era de locos que un general italiano se pasase por ahí sus órdenes y le impidiese hacer limpieza en Santander, esa ciudad roja; por tanto, que Mussolini le diera un silbido a Bastico y le llamara a casa. Mussolini lo entendió - como si no entendiera la necesidad de hacer limpieza, también a él le importaba la limpieza-, Bastico se marchó y la Falange empezó la fiesta también en Santander. ${ }^{191}$

La «pulida expresión» del texto sciasciano, irónica pero triste eco de la limpieza franquista, de la fiesta de los fusilamientos, desemboca luego en el pasaje de las mariposas de Madrid, que es una suerte de espiral narrativa sobre el vacío. Vacío del mundo, de un desierto donde cúmulos de pena y miedo se traducen en poesía (acaso, también, en cine, pero sin los excesos de la espectacularización) y donde se da paso a la interpretación de la guerra y, a fin de cuentas, del mismo relato. Mientras la no pulida expre-

188 Cfr. Traina, Leonardo Sciascia, cit., p. 230, y del mismo autor, "CCon l'emozione dell'azzardo". Appunti su Sciascia polemista", cit., p. 85.

189 Sciascia, L'antimonio, cit., p. 219.

190 Para una ficha técnica de la película, junto con citas y comentarios al guión, véase Sebastiano Gesù (ed.), Leonardo Sciascia, cit., pp. 247-250.

191 Sciascia, L'antimonio, cit., p. 189. Sobre la limpieza, cfr. De Luna, Il corpo del nemico ucciso, cit., pp. 116-117. 
sión de Ventura-Salerno presenta — todavía en el primer episodio, y sobre el mismo fondo urbano herido- a un oficial que recuerda a los legionarios victoriosos el "privilegio de liberar Madrid [...], ciudad mártir». A este propósito podríamos hacer nuestras, sin temor a exagerar, las palabras con que Dario del Corno saluda dos congresos dedicados al cine que se mide con la épica y el mito de dos maneras distintas: Hollywood y Pasolini; efectos especiales para apabullar al espectador, trama banal y diálogos inconsistentes, de un lado, y de otro, recurso a modelos trágicos y «anhelo de sentido que supere los valores de la racionalidad y de la historia»:

Una película es un relato total y compacto, que raramente se empoza en una espiral en el vacío para enderezar una interpretación, mientras que el mito, aun cuando asuma los modos del relato, no es más que una alusion abierta que espera el gesto que lo sitúe en el tablero de los significados. ${ }^{192}$

Incluso podríamos decir que El antimonio - y, en un nivel microestructural, el pasaje de las mariposas, colocado justamente al final de la primera parte del relato, del mito sciasciano (en el sentido más amplio y no solo como lo entienden Charles Mauron y/o Claude Ambroise)_ es «una alusión abierta que espera el gesto» — «Quiero ver cosas nuevas»— «que lo sitúe en el tablero de los significados».

Claro que Madrid es la meta luminosa de ese pasaje. Y la literatura tiene sus efectos especiales, sus relámpagos metafísicos, y ofrece cuando menos una entrada en materia, un acceso (no facilidad de acceso). Ya lo hemos visto. En ese sentido, Madrid no es solo la capital real del conflicto, polo de atracción o meta política e inflamada de los sublevados, franquistas y fascistas, que la bombardean desde el otońo de 1936. Liberada del peso inmediato de ciudad mártir, de las ruinas, del cuadro urbano herido, Madrid se erige también en símbolo de un viaje en el tiempo, un tiempo intuido, "puro", no datable, ausente, del que no hablan los manuales de historia, las cronologías del siglo XX. ${ }^{193}$

192 Del Corno, "Omero tradito dal cinema», suplemento Domenica del periódico Il Sole24 Ore, 208, 2005, p. 36, a propósito de VV. AA., I Greci al cinema. Dal peplum «d'autore» alla grafica computerizzata, Dupresa, Bolonia, 2005, y Elena Fabbro (ed.), Il mito greco nell'opera di Pasolini, Forum, Udine, 2005. La cita sobre el «anhelo de sentido» es de Fabbro.

193 Marc Augé, Rovine e macerie. Il senso del tempo (2003), Bollati Boringhieri, Turín, 2004 (El tiempo en ruinas, trad. Tomás Fernández Aúz y Beatriz Eguíbar, Gedisa, Barcelona, 2003). 
En el texto de las mariposas asistimos, en definitiva, a un viaje en el tiempo que es un paso a través del fuego, del miedo, pero también de la memoria, cuyo doble enigmático y a menudo inasible, el olvido, ${ }^{194}$ "no es un acontecimiento» — como sugiere Ricoeur— ${ }^{195}$ sino más bien «un estado», «una fuerza», que puede conducir incluso a la justicia y al perdón y, de ese modo, alimentar, en la misma medida que la memoria, la vida individual y la colectiva. Superando esta estrecha dualidad en aras de una solidaridad sin la cual el individuo no es imaginable, y en ese lenguaje-morada donde «todo nombre proprio es común, toda ordenación es ya colectiva». ${ }^{196}$

Y el pasaje sciasciano tiende precisamente a fundir (no a enfrentar) olvido y memoria, vida individual y colectiva, e incluso otros pares de opuestos no menos significativos: estatismo y dinamismo, ver y hacer. Empieza con "[yo] estaba sentado», pero se transforma en "[nosotros] dábamos vueltas», transfigurando enseguida ese «nosotros»-soldados mediante un enunciado metafórico (y metamórfico) en tercera persona del plural, esas «mariposas» que a la llama de Madrid «se aproximan hasta sentir que se queman y amplían el vuelo», hasta que "por un soplo de viento la llama les atrapa" y terminan compartiendo el destino de "miles y miles de personas» que habitan en la capital española.

A este respecto Paul Ricoeur podría aún sugerir, partiendo de Maurice Halbwachs, que no recordamos nunca solos, sino que nuestros recuerdos se completan con los de los demás, porque necesitan ser encuadrados en narraciones colectivas. Por otra parte, ese mismo yo dice, refiriéndose a un pueblo español: «de cuyo nombre no me acuerdo», invistiéndolo y representándolo luego con nombres de comunidades sicilianas: pueblos como «Grotte [...], Milocca» y ciudades como «Palermo [...], Caltanissetta», que en el «desierto» físico y mental reabren subterráneamente — pero (ya) colectivamente - el camino a Madrid, la lejana capital. Estrategia esta

194 Cfr. una vez más Yerushalmi, Loraux, Mommsen, Milner, Vattimo, Usi dell’oblio, cit.

195 Ricoeur, La Mémoire, l'histoire, l'oubli, cit., p. 652.

196 Gilles Deleuze, Claire Parnet, Dialogues, Flammarion, París, 1977, y col. Champs, 1996, p. 172: «Las diferencias no pasan por lo individual y lo colectivo, pues no vemos ninguna dualidad entre ambos tipos de problemas: no existe un sujeto de la enunciación, sino que todo nombre es común, toda ordenación es ya colectiva» (Diálogos, trad. José Vázquez, Pre-Textos, Barcelona, 1977). 
sugerida en parte por el propio Sciascia en un artículo de 1983 recogido en Horas de España, donde a la Sicilia española se superpone en el recuerdo «la de los lugares de la guerra civil [...], nombres y lugares que todavía me emocionan, como si me recordasen un primer amor intenso y desesperado». ${ }^{197}$ Tal vez Marc Augé glosaría esto diciendo que «hay que volver para escribir, por lo menos volver a casa», ${ }^{198}$ o si se prefiere, citando a James Hillman, volver a aquellos «lugares» que envían señales, que tienen recuerdos, pero sin ser poseídos por ellos, ${ }^{199}$ o sea, sin convertirnos en víctimas del genius loci, como se es víctima, en cierto sentido, de la mina de azufre y/o de la caverna.

Aunque conocido, no podemos dejar de recordar algo más cercano que la antropología de Augé y la psicología de Hillman, es decir, el hecho de que en la Italia moderna, gracias sobre todo al compromiso y la escritura de Giovanni Verga y otros autores sicilianos, las minas, y la de azufre en particular, son lugares de notables recuerdos literarios, que envían precisas señales, comenzando quizás por las que subrayan los lazos históricos y simbólicos de la mina con la infancia. Sin embargo, creo que las indicaciones de Augé y Hillman pueden ayudar realmente —en relación con lo sostenido hasta ahora sobre El antimonio - a acercarnos y entender mejor la aportación de Sciascia, es decir, a aprehenderlo con mayor autonomía y libertad, desvinculándolo de un horizonte todavía demasiado (o solo) literario, decimonónico y siciliano.

Ligado casi naturalmente a recuerdos de infancia del protagonista, que «se viste como si fuera un caballero", y al consiguiente florecer de un refranero popular del tipo de Verga («el pobre que va de soberbio termina siempre mal»), ${ }^{200}$ el genius loci de la mina de azufre está filtrado, de todas maneras, por la experiencia espańola, por una fuga y un regreso imposibles y por una superación final (hipótesis, por lo menos, de superación) de todo ello. Se diría, en suma, que se regresa pero sin ser esclavos del regre-

197 Sciascia, Ore di Spagna, cit., p. 60. Y cfr. Ricoeur, La Mémoire, l'histoire, l'oubli, cit., p. 147.

198 Augé, Rovine e macerie. Il senso del tempo, cit., p. 10.

199 Cfr. Hillman, L'anima dei luoghi. Conversazioni con Carlo Truppi, Rizzoli, Milán, 2004 .

200 Sciascia, L'antimonio, cit., p. 177. 
so, de la mina, del genius loci. Por eso es posible emprender la recuperación fuerte y autónoma de un lugar, de un imaginario, yendo más allá de Verga, de Sicilia, del siglo XIX, en pos de una realidad extensa y compartida por muchos italianos, entre lo individual y lo colectivo, en tiempo de paz y de guerra, en la patria o en el extranjero (en aquella Bélgica, por ejemplo, estudiada en los trabajos de Josette Gousseau), ${ }^{201}$ y con tramas y temas que dejan ver trazas significativas de El antimonio en la literatura italiana más reciente — no siciliana, si bien isleña - y también al hilo de una «memoria» semejante a la evocada, tan repetida como problemáticamente, en El antimonio.

Por poner un ejemplo, se podría pensar en un texto narrativo de Sergio Atzeni, El hijo de Bakunin (1991), que mezcla investigación y entrevista y trata de rastrear en Cerdeña entre los años veinte y cincuenta las huellas de un héroe con nombre y apellidos, Tullio Saba, pero que, de hecho, queda anónimo, fundido en personajes de la comunidad que conservan de él un recuerdo y que, entre uno y otro fragmento de vida, a veces, deben precisar que «de todas maneras, yo nunca he tenido buena memoria». La memoria de los varios yoes, la pluralidad del nosotros, las coordenadas del pueblo, las experiencias, las guerras fascistas, la mina, la infancia, hacen del breve pero diferente texto de Atzeni una prueba de la fuerza y la fortuna, tal vez, del relato sciasciano, más allá de la ubicación editorial de El hijo de Bakunin, la colección La Memoria, de Sellerio: «Desde niño [Tullio Saba] estaba convencido de ser quién sabe qué [...] lo vestían como a un príncipe»; "[la madre] no quería ver a su hijo minero» y en cambio lo será durante una parte (muy importante) de su vida, conociendo «mineros que habían estado en Bélgica y en Francia» y llegando a saber "muchas cosas que no estaban escritas en los periódicos, ni la radio decía, sobre la Guerra de España», guerra que tiene que ver - gracias a otro personaje, Velio Spano, que se confunde casi con el héroe (lo que ocurre, en mi opinión, en el filme homónimo de Gianfranco Cabiddu, de 1997)— con esas «experiencias que, para nosotros, formaban parte del mito». ${ }^{202}$

201 Gousseau (ed.), Sicilia e Belgio. Specularità e interculturalità, anales de la Facultad de Filosofía y Letras, Universidad de Palermo, Palermo, 1995, y Gousseau (ed.), Dallo zolfo al carbone. Scritture della miniera in Sicilia e nel Belgio francofono, anales de la Facultad de Filosofía y Letras, Universidad de Palermo, Palermo, 2005.

202 Atzeni, Il figlio di Bakunin, Sellerio, Palermo, 1991 y 2002, pp. 26, 18-20, 49, 52, 106 (El hijo de Bakunin, trad. Sara Palacios, Juventud, Barcelona, 1995). 
Desde esta perspectiva, la infancia es también para Sciascia un punto de partida (y un fuga: de un estado social y, en general, de cierta situación del hombre que hay que transformar) pero a la vez un punto de llegada (y por lo tanto de regreso: para recordar y reencontrar) y tal vez todavía, sobre todo (imposibles la fuga y el regreso) un viaje entre ambos puntos o polos: un viaje a través que nos permite no dejar de viajar, de recordar y ver o, al menos, de tener el deseo (y la voluntad) de ver cosas nuevas.

La enunciación colectiva del fragmento de las mariposas — «Dábamos vueltas en torno a Madrid» - abraza un final que se apoya en esa infancia dilatada que, para el héroe, trata de recoger y encarnar la alusión abierta del mito de manera casi arquetípica — diríamos con Franco Ferrucci-, entre una vida entendida como asedio a muros inexpugnables que encierran un espejismo de felicidad y una vida entendida como regreso. ${ }^{203}$ La infancia, entonces, tiende un puente entre el asedio externo e interno, entre el dolor del que sitia con fuego desde lejos (y regresa niño) y el dolor del que aún vive bajo ese fuego (y es el niño sitiado): ${ }^{204}$

de noche reverberaba rojo en el cielo, por los incendios que nuestros aviones iban a desatar; solo en algunos momentos pensaba que en aquella ciudad había niños [...] Pensaba: «el antimonio, el fuego», pero la reverberación era tan lejana, nos costaba tanta sangre y dolor aquella ciudad alucinante, que generalmente miraba la aureola roja de la muerte como cuando era niño, en el campo, miraba las lejanas girándulas de fuego de la fiesta de San Calógero: un luminoso y lejano juego de la noche.

Parece que Leonardo Sciascia tratase, a su modo, de «acceder de nuevo a la infancia como patria trascendental de la historia», de «experimentar», ${ }^{205}$ más allá de la ""pobreza de experiencia" de la época moderna» evidenciada por Walter Benjamin en los primeros ańos treinta y repensada, a partir del hombre contemporáneo privado de su biografía y de su experiencia, por Giorgio Agamben. ${ }^{206}$ Sciascia, pues, no se une a la catástrofe (al espectáculo de la catástrofe) y no quiere saldar cuentas con un pasado solo individual y cerrado, recluido en una guerra y/o en una mina de azufre.

203 Cfr. Franco Ferrucci, L'assedio e il ritorno. Omero e gli archetipi della narrazione (1974), col. Oscar-Saggi, Mondadori, Milán, 1991.

204 Sciascia, L'antimonio, cit., p. 191.

205 De nuevo considero, adaptándolo, el libro de Agamben, Infanzia e storia. Distruzione dell'esperienza e origine della storia, cit., p. 51.

206 Ib., p. 5. 
Que en el nacimiento y la desembocadura de esta tentativa estén la danza loca de las mariposas-soldados y la fiesta de san Calógero nos hace pensar, una vez más, en lo que Roger Caillois anota en su «Guerra y fiesta»:

En la conciencia común [...], la guerra y la fiesta albergan imágenes de muerte y confusión. [...]. Pero llega la hora del combate o de la danza y surgen nuevas normas. ${ }^{207}$

Con esta doble perspectiva, a través de Sicilia y España, la fiesta y la guerra, construcciones culturales impuras y filología no separada de una profunda intuición, Sciascia parece recoger algunos referentes de una vasta reflexión antropológica y sociológica difundida a partir de la segunda mitad de los años treinta y hasta los años cuarenta y cincuenta, gracias al Collège de Sociologie ${ }^{208}$ y otras aportaciones distintas aunque dialécticas de Caillois, Georges Bataille, Denis de Rougemont, traduciéndolas en literatura y asumiendo la invitación de Italo Calvino a «tratar de expresar algo "nuevo, auténtico, sufrido, fatigoso, no-del-todo-claro-ni-siquiera-a-timismo"». ${ }^{209}$

La entrada en materia, nutrida de gusto poético, incluso filológico, que propicia la imagen de las mariposas-soldados, no es realmente un fin en sí misma ni pretende, claro, resolver la ardua carga del héroe, anulando y dispersando su individualidad en el colectivo totalitario de la época o en el genius loci de la región siciliana, como sugeríamos antes. El reto de Sciascia, más bien, es mantenerse — podríamos citar todavía a Agamben"en viaje [...] a la infancia y a través de la infancia» (de un hombre, de un mundo). ${ }^{210} \mathrm{Y}$ en este viaje existe también la guerra, la "guerra como viaje» de la que habla precisamente Manuel Azaña en La velada en Benicarló (1939), texto prologado y traducido por Sciascia, junto a Salvatore Girgenti, en $1967 .^{211}$

207 Caillois, "Guerre et fête», cit., pp. 224-225 (Guerra y fiesta, ed. Gaëtan Picon, Guadarrama, Madrid, 1965).

208 Cfr. Denis Hollier, Le Collège de Sociologie (1937-1939), Gallimard, París, 1979, reeditado en la col. Folio-Essais, 1995, pp. 169-244 (y 199-203).

209 Cfr. Traina, Leonardo Sciascia, cit., pp. 229-230.

210 Agamben, Infanzia e storia, cit., p. 52.

211 Sciascia, prólogo a Manuel Azaña, La veglia di Benicarló (1939), Einaudi, Turín, 1967, p. XII (La velada en Benicarló. Diálogo de la guerra de España, ed. Manuel Aragón, Castalia, Madrid, 2005). 
En este discurrir entre la infancia (no el infantilismo) y la guerra, donde no hay lugar para el síndrome de Peter Pan y similares, ${ }^{212}$ El antimonio encuentra también su apoteosis como relato de formación, a lo largo de un recorrido en que se consideran y esparcen, como hemos visto, el fuego, el miedo, la memoria, la infancia y, ańadamos con Vittorini, «muchachos hambrientos, con hambre también de ciudades nuevas y de ver mundo", ${ }^{213}$ es decir, muchachos formados, para bien y para mal, en la guerra civil española, entre los horrores vividos en España y la toma de conciencia de tales horrores, asomándose al mundo como sujetos también políticos, también antifascistas.

Tal relato de formación alimenta pero no agota El antimonio, que, como sucede con Vittorini, busca el relato «abierto", no resuelto, entre la fuga y el regreso imposibles, y eso es así desde el exergo, como dijimos, y en cierto sentido incluso desde el título, con ese elemento químico que funde guerra y escritura pues «entra en la composición de la pólvora y de los tipos de imprenta». ${ }^{214}$ Porque los "muchachos hambrientos» crecen pero no concluyen en la guerra, en la pólvora, y potencialmente son el futuro, futuro del recuerdo, de la palabra, de la escritura: «El recuerdo humano es inseparable de la palabra» $\mathrm{y}$ "Escribir significa hablar más alto y durante más tiempo». ${ }^{215}$ Desde este punto de vista, se podría conjeturar que el veterano, que al principio habla a sus familiares y vecinos, tendrá la posibilidad (y la escogerá) de marcharse para hablar más alto y durante más tiempo. Como demuestran el final de El antimonio y la "génesis» misma del relato, «ejemplo de contaminación entre códigos escritos (historiográficos y literarios) y testimonios orales»:

El abogado Terenzio di Caltanissetta, que había sido oficial de las tropas enviadas por Mussolini a Espańa, y uno de Racalmuto enrolado con los fascistas con el fin de pasar a la otra parte y huir a América, han narrado a Sciascia episodios de aquella guerra. ${ }^{216}$

212 Cfr. Francesco M. Cataluccio, Immaturità. La malattia del nostro tempo, Einaudi, Turín, 2004, pp. 34-48, y la recensión de Goffredo Fofi en el suplemento dominical de Il Sole-24 Ore, 197, 2004, p. 29 (Inmadurez: la enfermedad de nuestro tiempo, trad. María Cóndor, Siruela, Madrid, 2006).

213 Elio Vittorini, Diario in pubblico, Bompiani, Milán, 1957, y col. Tascabili, 1991, p. 212.

214 Sciascia, L'antimonio, cit., p. 166.

215 Ferrucci, L'assedio e il ritorno, cit., pp. 7 y 8.

216 Ambroise, "Cronologia», en Sciascia, Opere 1956-1971, cit., p. LVI. 
Para poner de manifiesto la duplicidad ontológica de los «legionarios [...] capaces de desencadenar, a partir de cúmulos de pena y fatiga, ese felino arqueo de riñones que es la poesía ${ }^{217}$ — vuelvo a la feliz expresión de Di Grado, dejando aparte la acepción fascista del término, que ya Vittorini tiende a superar («aquellos que fueron llamados "legionarios"»)—, El antimonio, diríamos con Ejkenbaum, ${ }^{218}$ se beneficia también, técnicamente, de un doble estatuto narrativo: por una parte, el estatuto del cuento, que tiende a acumular peso, importancia — la «alusión abierta», el "gesto que lo sitúe en el tablero de los significados»— en ese final que evoca una "ciudad lejana [...] grande» y se cierra con la frase que más hemos citado, "Quiero ver cosas nuevas»; ${ }^{219}$ por otra parte, el estatuto de la novela, que tiene en el desenlace un punto de debilidad más que de fuerza, siendo las construcciones intermedias más importantes que el resultado final (pensemos, obviamente, en el pasaje de las mariposas de Madrid).

Entre la duplicidad ontológica legionarios/muchachos hambrientos y el doble estatuto narrativo cuento/novela, Sciascia no quiere reducir $E l$ antimonio a un relato de guerra y formación; antes bien, se sirve de tales coordenadas literarias para abrir el relato y hacerlo dinámico, prospectivo, especialmente en las últimas páginas, convirtiéndolo casi en un "diario público». En este caso, Vittorini, más que una fuente, es un mundo, el de Conversación en Sicilia (1938-1939), pero también su superación, el más allá que representa Diario público (1957).

En España se puede volver a ser niño, regresar casi a la «memoria de la especie», por decirlo con Ferrucci, es decir, al «hombre» que «recuerda hasta donde puede recordar», al «primer momento que recordamos»: «una mezcolanza de cosas diversas, sabiamente unidas; justo como las fuentes bibliográficas (no recordadas) están detrás de los libros que conocemos». ${ }^{220}$ Y, en cuanto niños, se puede volver más fácilmente a casa, pero no está

217 Di Grado, «Sciascia, il cinema e (fra l'altro) l'Europa: (bianco e) nero su nero», cit., pp. 71-72.

218 Boris Ejkenbaum, "Teoria della prosa» (1927), en I formalisti russi (1966), ed. de Tzvetan Todorov, Turin, Einaudi, 1968, pp. 239-241.

219 Sciascia, L'antimonio, cit., p. 230.

220 Ferrucci, L'assedio e il ritorno, cit., p. 7. 
claro que se pueda o que se esté en disposición de "tocar marro" en seguida y «liberar a todos». Entender esto y a la vez no permanecer esclavos de la casa, del mito y del genius loci de la infancia y de la mina, de la caverna, es el primer paso para volver a acceder, realmente, a "cosas nuevas» (también a Madrid). Porque, ante todo, las "cosas» no tienen que ver solo con la vista-visión de Sicilia, del pueblo, del campo, del desierto de luz, de la mina de azufre, del fuego, que al final es la vista-visión inflamada de la guerra civil española: «España era también la mina de azufre». ${ }^{221}$ En este sentido, España confirma a Sicilia como grado cero de la escritura sciasciana y, al mismo tiempo, hace que el mundo sea virgen, algo nuevo y abierto en que empezar a vivir, gracias a construcciones culturales impuras y sin unificadoras y peligrosas superposiciones ideológicas.

El antimonio, entonces, también en cuanto biografía (en última instancia, "autobiografía») sin continuación, es un exorcismo complejo, solo en parte retomado y ratificado en la aproximación antifascista a las "cosas nuevas», rastreable dentro de una tradición literaria y de un compromiso muy queridos para Sciascia, a través justamente de Elio Vittorini. Porque las «cosas nuevas» tienen que poder reinventar el horizonte existencial de aquellos «muchachos hambrientos, con hambre también de ciudades nuevas y de ver mundo, no solo de pan y cigarrillos», como escribe precisamente Vittorini en el número 1 de Politecnico, ${ }^{222}$ septiembre de 1945.

De acuerdo con lo sugerido poco antes, más implícitamente, estas palabras de Vittorini acaban en las páginas de Diario público (1957), que para Sciascia — lo confiesa en 1981- «quedarán» realmente, ${ }^{223}$ mientras que no resisten tan bien el tiempo, como significativamente advierte (la advertencia se intuye ya al final de El antimonio), las de Conversación en Sicilia (1938-1939), su obra maestra, otro viaje en la memoria y en la isla, con mucho de fuga-regreso-(fuga), del que hablaremos más adelante, en relación siempre con la guerra civil española.

Desde luego, la imagen vittoriniana relativa a las «ciudades nuevas» y al «ver mundo» influye en Sciascia cuando escribe El antimonio (1960), no

221 Sciascia, L'antimonio, cit., p. 228.

222 Vittorini, Diario in pubblico, cit., p. 212.

223 Citado por Ambroise, "Cronologia», en Sciascia, Opere 1956-1971, cit., p. LIX. Pero cfr. Perrone, Sciascia, Vittorini e la Spagna, cit., pp. 252-253. 
solo porque nuestro escritor privilegie ya (o con previsión) las páginas de Diario público, sino también por la proximidad cronológica del libro de Vittorini con el naciente mundo de Los tios de Sicilia (1958 y, sobre todo, 1960) y, si se quiere, con los «artículos publicados por Sciascia en el periódico L'Ora entre 1964 y 1968, dentro de la sección "Quaderno", que tenía esa forma de diario público tan cara a Brancati y Vittorini y que caracteriza también Negro sobre negro», ${ }^{224}$ de 1979 (y estamos casi en 1981, año del que hemos partido).

En tanto que singular autobiografía, con un tono a la vez narrativo y testimonial, de un militante de la cultura en cuya toma de conciencia y en cuya memoria, individual y colectiva, la guerra civil de Espańa tiene gran peso, Diario público de Elio Vittorini puede haber trazado o, por lo menos, sugerido una ruta para Sciascia al escribir Los tíos de Sicilia, que, entre su primera y segunda edición, 1958 y 1960 repectivamente, busca una vía para unir testimonio y narración.

El experimento vittoriniano puede haber ejercido su influencia, en particular, sobre el último relato del conjunto, entendido como «primeras páginas de una biografía que no tuvo continuación» —-como decía Ambroise- y como un texto casi autobiográfico que pone en escena una experiencia fundante - la guerra civil de España, ligada también a la infancia y adolescencia de Sciascia (1921), más allá de los límites generales evocados más arriba- y la proyecta, por obvias razones cronológicas, sobre un personaje otro que, sin embargo, esconde al escritor siciliano y su no siempre evidente ni fácil cruce de ensayo y narración.

Admitida la compleja recepción sciasciana - especialmente en relación con la guerra civil española- del Diario público de Vittorini, será útil dedicar algunas palabras a la imagen de las «ciudades nuevas» y del «ver mundo». De esta última se sirve Vittorini, en principio, para describir la brusca desilusión de una generación, evocando la tragedia de Guadalajara «donde [los muchachos hambrientos] aprendieron lo que puede haber de

224 Traina, “"Con l'emozione dell'azzardo”. Appunti su Sciascia polemista», cit., p. 72; Perrone, «Sciascia, Vittorini e la Spagna», cit., p. 245; Tedesco, "Avevo la Spagna nel cuore". Sciascia, la Sicilia, la Spagna», cit., p. 16, que remite a los relatos El antimonio y La sexta jornada para ejemplificar un «legado [...] más vittoriniano que brancatiano». 
distinto en el mundo, lo que puede ser nuevo para vivir, no solo para ver». La imagen del "ver mundo» se traduce en la experiencia de «vivir» el mundo y acompaña a los muchachos-legionarios en el proceso de su toma de conciencia. Exactamente como en el relato de Sciascia, Vittorini, después de la guerra, la batalla, el fuego, desplaza la narración hacia una toma de conciencia, presentándola - en líneas que casi resumen, ante litteram, El antimonio - como "una educación política» que escapa a la "transmisión de experiencia de padres a hijos y de viejos a jóvenes» y se adquiere "con duras y brutales lecciones tomadas directamente de las cosas y dentro de las cosas, mediante lentas maduraciones individuales, fatigosos descubrimientos de la verdad, toda una autoeducación entre julio del 36 y mayo del 39"; ${ }^{225}$ es decir, sustancialmente, al amparo del Pacto de Acero y durante "la guerra civil de España», que "nos había enseñado también a buscar» y encontrar "el viejo antifascismo» y a la cual Sciascia, como sugiere Ambroise, "retrotrae [...] su propia, incipiente y precoz toma de conciencia antifascista». ${ }^{226}$ Recientemente, ${ }^{227}$ Traina añade: «la Guerra de España es una situación de neta contraposición, que tiene un valor fundante en la mentalidad sciasciana, ya que daba lugar —al menos, en el plano ideal - a nobles elecciones de parte de signo antifascista; el correlato "humano, demasiado humano" [o sea, de crítica o de "cruce» de la ideología, diríamos con Madrignani] ${ }^{228}$ de semejante situación es confiado luego, en edad madura, a un relato espléndido y complejo como El antimonio».

En efecto, en la voluntad de «ver cosas nuevas» que cierra El antimonio - pero que también está en su origen — hay ya una crítica de la cul-

225 Vittorini, Diario in pubblico, cit., pp. 212-213, y cfr. de nuevo Perrone, «Sciascia, Vittorini e la Spagna», cit., pp. 254-255 (aunque es otra la conclusión).

226 Ambroise, "Cronología», en Sciascia, Opere 1956-1971, cit., p. LVI.

227 Traina, “Con l'emozione dell'azzardo”. Appunti su Sciascia polemista», cit., p. 86.

228 Cfr. una vez más Madrignani, "Cassola e altri "buoni maestri”", cit., p. 96: «El mejor Sciascia, que ha dejado un vacío que no vemos cómo podrá llenarse, es, más que el polemista y el estimulador de problemas civiles e inquietudes morales, el narrador-pensador que atraviesa las ideologías aun cuando parezca asumirlas. No es la causa o controversia concretas lo que cuenta, sino su disposición a repensar, reformular y verificar los puntos centrales de nuestro vivir en sociedad: iluminar, como querían los philosophes, las causas recónditas de los lenguajes y comportamientos oficiales, no en nombre de una ideología mejor o superior, sino de una voluntad de conocimiento que se propone como "distinta" en relación con el saber conformista, domesticado o masificado». 
tura, de la ideología del Sciascia maduro, es decir, una puesta en tela de juicio de sí mismo, en cierto modo, pero a partir de un reto cognoscitivo y de una búsqueda ilustrada. Reto y búsqueda complejos, desarrollados «a la sombra de pólemos», característica del Sciascia autor, novelista, historiador, antropólogo de la cultura. En seguida nos hacen pensar en el viaje dieciochesco de El archivo de Egipto (1963), ${ }^{229}$ un viaje que todavía tiende hacia la infancia de un mundo y de otra "guerra civil», imaginado más allá de la «experiencia» que no se convierte dócilmente en «recuerdo» y de la «indiferencia» que «escalda» (verbo más que revelador, obviamente).

\section{Conclusiones provisionales y aperturas}

Nuestras conclusiones - no se trata, o no solo, de auténticas conclusiones - no podrán ser sino provisionales y sugerir ulteriores ramificaciones, tal vez a partir de una suerte de back to the source, de doble regreso a las fuentes, o sea, a los orígenes literarios y humanos de un relato, en parte resumidos y disimulados en una sintética presentación a la que Leonardo Sciascia confía las «sugestivas razones» por las que ha «titulado el relato El antimonio»:

Los mineros del azufre de mi pueblo llaman antimonio al grisú. Entre los mineros circula la leyenda de que el nombre proviene de anti-monje, pues antiguamente lo trabajaban los monjes y, manejándolo sin precaución, morían por ello. Ańádase que el antimonio entra en la composición de la pólvora y de los tipos de imprenta y, en otros tiempos, en la de los cosméticos. Sugestivas razones estas, para que yo haya titulado el relato El antimonio. ${ }^{230}$

La «concisa presentación» contiene «una extraordinaria riqueza de aspectos y reflexiones» y es posible, incluso, confiarle la medida del relato, ese «restringido número de páginas» que, por serlo, hay que contar realmente, como sugiere Antonio Llorens, entre las «más complejas y sensibles que hayan sido nunca escritas sobre la Guerra de España, sobre Sicilia y sobre la condición humana». ${ }^{231}$ Porque en El antimonio parece confluir

229 Cfr. Traina, Leonardo Sciascia, cit., p. 230, quien, desde otro punto de vista, observa: "El antimonio es, antes que El archivo de Egipto, el texto en que Sciascia más se pone en cuestión, excavando en lo "profundo" de su protagonista".

230 Sciascia, L'antimonio, cit., p. 166.

231 Llorens, "Una vita venduta, un film rubato", en Sebastiano Gesù (ed.), Leonardo Sciascia, cit., p. 113. 
buena parte de la literatura sobre la guerra civil española y buena parte de la literatura (también crítica, filosófica) de la condition humaine que a menudo se vincula a aquella, al menos desde los años treinta y hasta los ańos cincuenta, y que puede situarse, por poner un ejemplo con referentes ya conocidos, entre la antropología novelesca «en primera persona» de Malraux ${ }^{232}$ y la «antropología filosófica» de La condición humana de Arendt. $^{233}$

La fuerza de estos referentes y su complejo entrecruzamiento, así como su irradiación en plena guerra fría y después de Stalin, es rastreable en grandes escritores europeos de la generación de Sciascia entre los años cincuenta y sesenta, con muy distintas intensidades, jugando a veces con la farsa y lo grotesco. En este sentido, presentaremos rápidamente el caso del escritor suizo en alemán — «Je suis un vrai Suisse»— Friedrich Dürrenmatt. Pero tengamos presente desde ahora que Suiza es también una isla — "Je vivais sur une île»—y que Dürrenmatt se proyecta a sí mismo en sus libros: «Yo no llevo un diario íntimo. Mi diario son mis Obras». Es verdad que en el escritor suizo hay un desapego, poco sciasciano, del espectador: «Los ańos adolescentes tienen su importancia. Yo tenía veinte años durante la guerra. [...]. Vivía en una isla, o sobre una balsa que iba por el agua. Observaba a lo lejos, como un espectador, el crepúsculo de los dioses». Y encima Dürrenmatt no tiene una tradición literaria suiza de referencia: «No veo ninguna tradición suiza que pudiera contar para mí», ${ }^{234}$ mientras que Sciascia tiene detrás una gran tradición siciliana, sobre la que aún habremos de detenernos.

Antes que Sciascia, en Italia y desde ese particular ángulo visual que es Sicilia, una fuerte y extensa conexión entre antropología novelesca y antropología filosófica, entre condición humana y Guerra de España y/o fascismo de los años treinta, está presente en Vittorini, pero también en Vitaliano Brancati, "otro de sus amados escritores de referencia», ${ }^{235}$ autor

232 Gaëtan Picon, Malraux, col. Écrivains de Toujours, Seuil, París, 1953 y 1974, pp. 11 y ss.

233 Ricoeur, prólogo (1983) a Hannah Arendt, Condition de l'homme moderne, cit., p. 14.

234 Las citas proceden de Entretiens avec Le Monde, 2. Littératures, Editions La Découverte y diario Le Monde, París, 1984, pp. 66-67.

235 Traina, "Con l'emozione dell'azzardo". Appunti su Sciascia polemista», cit., p. 85. 
de El guapo Antonio (1949), sobre el que obviamente volveremos, pero también del «relato El tedio del '937 [...] sobre la vida en Caltanissetta en torno a 1937, años del Imperio y de la guerra en España", como se lee en Negro sobre negro (1979). ${ }^{236} \mathrm{Y}$ entre los cuentos brancatianos es imposible no pensar en El viejo con botas (1944), auténtica obra maestra donde Aldo Piscitello, en los «años más negros, [...] el 36 y el 37» (también el «año siguiente»), vive "solo como una mosca en enero" y casi en el seno de la misma comunidad que el protagonista de El antimonio. A la mujer que aplaude, batiendo contenta las manos «ante una radio que proclamaba el bombardeo de Valencia», Piscitello opone una serie de preguntas de las que Sciascia se habrá acordado al final del fragmento de las mariposas:

¿Y tú eres católica? ¿Tú eres cristiana? ¿Tú te santiguas y besas el Corazón de Jesús? ¿Tú, que caes en éxtasis por el bombardeo de una ciudad donde hay niños, mujeres mejores que tú y enfermos?237

En El antimonio, la representación es más extrema y tal vez toca una variante más triste y menos irónica de la condition humaine, acogida con una pena cuya importancia hemos indicado pero, sobre todo, con una mezcla inédita de crítica y comprensión humana, incluso cuando esa condenada condición fluctúa vergonzosamente entre aventuras de corte épico, caballeresco, lugares comunes acaso leídos en los periódicos — «la Guerra de España me ha enseñado a no creer en los periodistas"—- 238 y episodios atroces buenos solo para la propaganda y la exaltación retórica de un fascismo que, en cuanto fruto de esa propaganda, de esa retórica (y de la guerra), el protagonista ha reconocido y desenmascarado.

Como decíamos, de esta triste variación de la memoria disfrutan ávidamente, al final del relato, «los viejos» $\mathrm{y}$ «el secretario fascista», que oscilan entre la ignorancia y la propaganda y son esclavos de ese tedio en el que Sciascia no quiere hundir a su personaje. Tedio que, para Brancati, es precisamente «el signo más grave de disgusto existencial bajo el régimen fascista ${ }^{239}$ y que puede convertirnos en espectadores, como la mujer de

236 Sciascia, Nero su nero (1979), en Opere 1971-1983, cit., p. 666.

237 Brancati, Il vecchio con gli stivali (1944), L'Acquario, Roma, 1945; 2. a ed. ampliada en Bompiani, Milán, 1946 y 1958, y en la col. Oscar de Mondadori, Milán, 1971, pp. 126 y $128-129$.

238 Sciascia, L'antimonio, cit., p. 216.

239 Traina, “Con l'emozione dell'azzardo”. Appunti su Sciascia polemista», cit., p. 85. 
Piscitello, pero no de esos atentos que encontramos en Dürrenmatt. Un tedio que tendencialmente, bien lejos de la dictadura y del fascismo, podría llevar al protagonista de El antimonio a una historia previsible, haciéndolo «recaer "en la opaca realidad de la vida muelle" que, según Sciascia, aguardaba incluso a "los muchos meridionales que habían participado valerosamente en la Resistencia" y habían vuelto luego a sus pueblos». ${ }^{240}$

Es más, Sciascia parece compartir — dándole la vuelta — la liquidación que Vittorini hace en 1945 de la "transmisión de experiencia de padres a hijos y de viejos a jóvenes». Transmisión o "transmisibilidad de la experiencia» que para Calvino, a la vista de los difíciles ańos de la posguerra, es de «escasa eficacia» y «sigue siendo una de las realidades más descorazonadoras del mecanismo histórico y social»: "la historia continúa moviéndose a empujones no totalmente controlados, a golpe de convicciones parciales y nada claras». ${ }^{241}$ Notemos que estas observaciones surgen en "páginas autobiográficas" de 1979 — año del tantas veces citado Negro sobre negro-, cuando Calvino se pregunta: "iTambién yo he sido estalinista?» y "¿Quién era Stalin entre el 45 y el 53, aquí en este Occidente que se había configurado con la victoria aliada y la guerra fría?». ${ }^{242}$

Con La muerte de Stalin (1957), Sciascia narrador busca una respuesta a esta pregunta más de veinte años antes, procediendo, podríamos decir, a una cierta deconstrucción del mito del hombre político, en estrecho contacto con las revelaciones de Kruschov sobre los crímenes de Stalin y a partir de la difícil y parcial toma de conciencia de un zapatero. Desde el comienzo del verano de 1956 se publican informes, informaciones desconcertantes y reflexiones en caliente de políticos y escritores. El relato es

240 Ib., p. 86, que cita a Sciascia, Quaderno, eds. Vittorio Nisticò y Mario Farinella, Nuova Editrice Meridionale, Palermo, 1991, p. 77.

241 Calvino, «Sono stato stalinista anch'io?», La Repubblica, 16 de diciembre de 1979, suplemento dedicado a Stalin con motivo del centenario de su nacimiento, y recogido luego en Eremita a Parigi. Pagine autogiografiche, introd. Esther Calvino, col. I libri di Italo Calvino, Mondadori, Milán, 1994 y col. Oscar, 1996, p. 199. Cfr. también el siguiente artículo de la compilación, "L'estate del '56», pp. 204-210 (Ermitaño en París: páginas autobiográficas, trad. Angel Sánchez-Gijón, Siruela, Madrid, 2004).

242 Ib., pp. 196 y 197. 
también un modo, trufado de ironía, de rehuir la crónica de la época, que deja a muchos intelectuales y camaradas "con la boca abierta", y de transformarla, en ciertas páginas, casi en una comedia. Léase el pasaje de los «retratos de Stalin", que no puede dejar de traer a la mente una divertidísima escena de Cama de tres plazas (1960) de Steno, cuando Totò vuelve de Rusia y reclama casa y esposa, que se ha vuelto a casar, con Peppino, y con este termina en el lecho y durmiendo solo después de haber sustituido un cuadro por el retrato del «bigotudo», exclamando: «Yo, si no lo siento sobre mi cabeza, no puedo dormir [...], lo mío es algo de los nervios». ${ }^{243} \mathrm{Y}$ el zapatero Calógero, con los norteamericanos ya en Regalpetra, «recortó de una revista americana dos retratos de Stalin, les puso un buen marco y uno lo colgó en la tienda, otro en el dormitorio, cerca de la Virgen de Pompeya que su mujer tenía sobre su lado de la cama. La esposa comentó displicente: “¿Ese es tu padre?”, pero no dijo nada más al ver cómo se ponía Calógero». ${ }^{244}$

Por haber querido sustraerse a la crónica, La muerte de Stalin no es fácil de descifrar desde un punto de vista histórico: histórico-ideológico e histórico-literario. De hecho, si bien es cierto que se trata de un relato que nos interesa, en un nivel temático, por sus alusiones a la guerra civil española, y en un nivel estructural, porque confluye en la primera edición de Los tíos de Sicilia (1958), es un texto que nos fascina ante todo, más en general, como un ejemplo ulterior de esa historia que "continúa moviéndose a empujones no totalmente controlados, a golpe de convicciones parciales y nada claras», y que se adquiere con «duras y brutales lecciones tomadas directamente de las cosas y dentro de las cosas, mediante lentas maduraciones individuales, fatigosos descubrimientos de la verdad, toda una autoeducación».

Pero en aquellos años no hallamos solo al Sciascia narrador de $L a$ muerte de Stalin. Está también el Sciascia ensayista, crítico, traductor, que

243 Con Peppino, coprotagonista «en un papel socialmente más elevado», protestando inútilmente: « $Y$ yo debo dormir con ese!» Cfr. Matteo Palumbo, «La trasgressione e la norma: Totò, Peppino e le classi sociali», en Pasquale Sabbatino y Giuseppina Scognamiglio (eds.), Peppino De Filippo e la comicità del Novecento, actas del congreso interdisciplinar, 24-25 de marzo de 2003, Nápoles, y 26 de marzo de 2003, San Giorgio a Cremano, Edizioni Scientifiche Italiane, Nápoles, 2005, pp. 101-108.

244 Sciascia, La morte di Stalin, en Los tíos de Sicilia, cit., p. 77; pero cfr. pp. 76-80. 
se ocupa todavía de la guerra civil española entre los años cincuenta y sesenta, digamos que entre La sexta jornada (1958) y el prólogo (1967) a La velada en Benicarló. Textos en los que Stalin permanece - tendremos ocasión de subrayarlo- como punto de referencia casi intacto. Y este es un dato importante. Parece, en efecto, como si en el mismo periodo Sciascia mantuviese con vida a dos Stalin. El hecho es que la guerra civil española, como hemos visto, es una experiencia fundante para el escritor siciliano, perteneciente al tiempo dilatado y dilatable de la infancia/adolescencia, cuando los crímenes de Stalin - y las noticias sobre ellos- estaban muy lejos de saberse.

Así, en La sexta jornada se denuncia más bien la actitud antidemocrática de los Estados Unidos, que ayudan a Franco en plena guerra fría y, actuando de ese modo, demuestran —atención al paréntesis- que «el diagnóstico marxista (queremos decir estalinista) del fenómeno fascista sigue siendo sustancialmente exacto». ${ }^{245}$ En el corto pero denso prólogo a La velada en Benicarló, Sciascia llega a la conclusión —atención, de nuevo, al paréntesis- de que «el moralismo de Azaña coincidió con la visión política de las cosas españolas que entonces tuvo Stalin (si no se quiere negar sentido político a Stalin)». ${ }^{246}$

Claro que hoy (más que ayer) Azaña ${ }^{247}$ es considerado también responsable de haber alimentado enemigos dentro de la República y de haber

245 Sciascia, La sesta giornata (1958), en VV. AA., La noia e l'offesa, Sellerio, Palermo, p. 158.

246 Sciascia, prólogo a Manuel Azaña, La veglia a Benicarló, cit., p. XIII.

247 Mientras que la idea que Leonardo Sciascia tiene de Azańa es más parecida, en los años cincuenta-sesenta, a la de Aldo Garosci, Gli intellettuali e la guerra di Spagna, Einaudi, Turín, 1959 [Los intelectuales y la guerra civil de España, Júcar, Gijón, 1981], que dedica un capítulo al presidente, pp. 89-109, titulado significativamente "La angustia de Manuel Azaña». En él —aun reconociendo en seguida que «la memoria del último presidente de la República española, sin duda la personalidad más fuerte que ha producido la clase republicana, sigue siendo todavía hoy motivo de controversia»— sugiere que "Azaña fue un ilustrado", "un hombre de la nueva república, austeramente moderno en la concepción de su tarea», "volcado en el alto ideal de la resistencia republicana" pero sin el poder ni la fuerza para «elaborar otro ideal más complejo en el caos de la guerra civil y bajo el peso de la inmensidad del desastre». En ese sentido, Azaña queda en parte absuelto, pero en parte se le hace culpable porque, creyendo en la sinceridad de los comunistas en virtud de la consigna de Stalin, como dice en La velada, no se pregunta por la naturaleza de esta "consigna» (las citas proceden de las pp. 89, 90, 92, 106). Es revelador que en el capítulo dedicado a Ramón J. Sender, pp. 160-178, sobre el que volveremos, Garosci recuerde de 
debilitado la frágil democracia española. Stalin y Azaña pueden ser comparados en este sentido no como factores políticos de racionalismo y moralismo, sino como elementos negativos de aquel eclipse de la democracia que conduce a la derrota de los republicanos entre 1936 y 1939, entre un «eclipse parcial: España republicana» y un «el eclipse total: España de Franco». ${ }^{248}$

No obstante, en los años cincuenta (desde su primera mitad, donde se produce la muerte de Stalin) es fácil encontrar en otros escritores el sufrido y «no-del-todo-claro» punto de vista de Leonardo Sciascia. Pensamos en Friedrich Dürrenmatt, ${ }^{249}$ un autor amado por el escritor siciliano, que le cita y «reescribe» su obra en sus últimos libros, El caballero y la muerte en particular, pero también Puertas abiertas y Una historia sencilla, su despedida narrativa. En cierto modo se trata casi de un compañero de viaje, porque Dürrenmatt, que pertenece a la misma generación de Sciascia, es otro narrador-pensador completo, convencido de que «no existen problemas de los que pueda prescindir»: ${ }^{250}$ "No hay nada más penoso que quienes subdividen el pensamiento del hombre en uno del que no se puede prescindir y otro del que sí. Entre ellos se esconden nuestros futuros carniceros».

nuevo a Azaña — una presencia, de todas maneras, casi vertebradora del libro — en estos términos: "Pero la lenta tenacidad y el modo cauto, casi indirecto, con que el escritor ha vuelto a los temas de la guerra española están hablando de un esfuerzo más intenso, de una fidelidad distinta y más sutil, no menos completa, a los motivos de su exilio. De modo que pensamos que no es casual que Sender nos haya dado, junto con Azańa, la mayor creación nacida de los acontecimientos de la guerra civil». Por tanto, del Sciascia prologuista de La velada no se deduce exactamente (ni positivamente) el paralelismo Azaña/Stalin, pero de todos modos aflora allí un intelectual y un político íntegro, un ilustrado y un escritor; imagen de Azańa que, a fin de cuentas, pudo fascinar y capturar la atención de Sciascia en aquellos ańos: el Sciascia de El archivo de Egipto, para entendernos. Para una posterior, "particular evolución del iluminismo sciasciano", especialmente a partir de "textos de los años setenta», cfr. Traina, Leonardo Sciascia, cit., p. 133.

248 Gabriele Ranzano, L'eclissi della democrazia. La guerra civile spagnola e le sue origini, 1931-1939, Bollati Boringhieri, Turín, 2004, pp. 421-501 y 502-569.

249 Léanse dos capítulos de Traina, "L'Ars moriendi di Sciascia» e "L'ultima speranza» en La soluzione del cruciverba. Leonardo Sciascia fra esperienza del dolore e resistenza al Potere, cit., pp. 129-156 y 157-172. Cfr. Carmelo Spalanca, "Il gioco degli specchi. Modelli italiani e modelli europei nel Cavaliere e la morte di Leonardo Sciascia», en Amedeo Quondam (ed.), Il Canone e la Biblioteca. Costruzione e decostruzione della tradizione letteraria italiana, Bulzoni, Roma, 2002, vol. 2, pp. 613-625.

250 Cfr. la reciente propuesta de Dürrenmatt, Una partita a scacchi con Albert Einstein (1979), Casagrande, Bellinzona, 2005, p. 53 (Albert Einstein, trad. Juan del Solar, Tusquets, Barcelona, 2003). 
Al igual que Sciascia, el escritor suizo desmonta el mecanismo de la novela policiaca para hacer de ella otra cosa, una creación literaria más compleja, menos clara y masificada, hecha de muchos puntos de vista y todos legítimos, incluidos los de los monstruos. Como ejemplo bastan algunas citas de La sospecha (Der Verdach, 1953): "La incuria, la manga ancha, he ahí lo que hacía el mundo insoportable; por incuria el mundo se estaba yendo a pique. Este era el peligro, ¡nada de Stalin y los camaradas!»; «Fue en diciembre del 44 [...]. Luego en enero del año siguiente, cuando el sol glacial de la esperanza empezó a brillar a lo lejos, en el horizonte, sobre Stalingrado»; "Cuando se firmó ese pacto famoso, el pacto de los señores Stalin y Hitler, tampoco entonces dudé de su necesidad, había que salvar la gran Patria soviética. Sin embargo, cuando una hermosa mañana, tras semanas de viaje en un vagón de animales desde la profunda Siberia, fui arrastrada por los soldados rusos [...] y vi en la niebla gris despuntar en la orilla opuesta los negros uniformes de los SS, entonces comprendí la traición, no solo a nosotros, pobres diablos destinados a Stutthof, sino a la idea misma del comunismo, que solo puede tener sentido si coincide con la del amor al prójimo y a la humanidad»; «Conozco a esta gente, segura de su perfecto derecho a afirmar que uno y uno son tres [...]. Para ellos la claridad es algo equívoco porque exige carácter. No sospechan siquiera que un comunista decidido - por citar un ejemplo poco apropiado, pues la mayor parte de los comunistas lo son como pueden serlo la mayor parte de los cristianos, es decir, con base en un malentendido-; no tienen la más mínima idea de que un hombre de ese tipo, que cree con toda el alma en la necesidad de la revolución y que solo esa vía, aunque pase por millones de cadáveres, puede conducir al bien y a un mundo mejor, es mucho menos nihilista que ellos». ${ }^{251}$

Podríamos ampliar la reflexión, de modo no tan paradójico, con Karl Barth, teólogo de Basilea, que en enero de 1960, al publicar la tercera parte de su breve pero intensa Autobiografía critica (1928-1958), relativa a "Los problemas de la paz (1948-1958)», declara y pide al mundo desde su «Suiza natal, donde, cosa notable, hay muchos pequeños McCarthy»: "Considero el anticomunismo, por principio, un mal mayor que el propio comunismo [...]. ¿Hemos olvidado que lo que está en juego en esta rela-

251 Cfr. Dürrenmatt, Il sospetto (1953), Feltrinelli, Milán, 1987 y 2003, pp. 16, 33, 85 y 110-111 (La sospecha, trad. Juan José del Solar, Tusquets, Barcelona, 1996). 
ción "absolutamente hostil", a la que todo buen ciudadano en Occidente está ahora obligado y por la que daría todo, es una típica invención (y una triste herencia) de difuntos dictadores y que solo "el Hitler dentro nosotros" puede ser anticomunista por principio? [...]. ¿No nos alegramos acaso, y con razón, por la contribución soviética a la victoria sobre el nacionalsocialismo? [...]. Creo que, alejados del miedo al fuego, estamos jugando con él irresponsablemente». ${ }^{252}$

El cuento La muerte de Stalin se publica en el número de enero de 1957 de Tempo presente y forma parte luego, como se dijo, de la primera edición de Los tíos de Sicilia, aparecida en 1958. Puesto en una perspectiva internacional, como La tía de Sicilia - primer relato de aquella edición- y El antimonio —último de la segunda-, La muerte de Stalin muestra la historia que se está haciendo, de la Guerra de Espańa al pacto germano-soviético Ribbentrop-Molotov de 1939, del desembarco aliado en Sicilia de 1943 a las elecciones italianas de 1948 que gana la Democracia Cristiana y, por supuesto, de la muerte de Stalin en 1953 al XX Congreso del PCUS en 1956 y la denuncia de los crímenes estalinistas protagonizada por Kruschov. La Guerra de España, una vez más, está en el origen de una trayectoria humana compleja, que supera esa guerra, como se intuye al final de El antimonio. Relato que, en el conjunto de Los tíos de Sicilia, podría representar casi un precedente de La muerte de Stalin, cuyo protagonista, sin embargo, se enroca en la isla y en su pueblo - a pesar de algún salto a la ciudad-, además de en sus convicciones, no precisamente fáciles de mantener en la Italia que va del $45 \mathrm{al} 53 \mathrm{y}$, con mayor razón, después: «Así estaban las cosas. Stalin ha muerto, pero el comunismo está vivo. Y Stalin, hasta la guerra victoriosa, había sido un gran hombre». ${ }^{253}$

En el resumen «histórico» del relato y en las citas que de él pueden extraerse, es fácil encontrar puntos de contacto retrospectivos con el texto de Dürrenmatt. Conviene tener presente la novelística negra que practicará Sciascia, como hemos hecho a propósito de $A$ cada uno lo suyo (1966),

252 Karl Barth, «I problemi della pace» (1960), en Autobiografia critica (1928-1958), introd. de Piergiorgio Grassi, La Locusta, Vicenza, 1978, pp. 91, 85, 86, 89.

253 Sciascia, La morte di Stalin, cit., p. 93. 
a partir de coincidencias con El antimonio, que no se puede insertar por completo en un horizonte filológico ni reducir a mero juego literario. Como corroboración, a mediados de los sesenta, para La muerte de Stalin pueden ser útiles las memorias de Robotti, "víctima de la inquisición estalinista en la Unión Soviética» que no obstante permanece fiel a la «idea comunista" que, nos dice Sciascia, "ha salido dolorosamente victoriosa» — como, en el relato, la "guerra» de Stalin, ahora "imbécil” inquisidor»-. Observa Traina: "En el 65 el juicio sobre Robotti se tiñe de humana comprensión por la coherencia y la firmeza moral del hombre, y el epíteto "imbécil" se reserva a su inquisidor». La coherencia harto valerosa de Robotti, incomprensible en un plano lógico y fáctico pero afectuosamente comprensible en el plano humano, es medida con el mismo patrón que Sciascia reservaba al zapatero estalinista que protagoniza su relato La muerte de Stalin. ${ }^{254}$

Por decirlo con Calvino - que, desde otro ángulo visual, retrocede en la historia para partir, de todos modos, de finales de los ańos setenta, cuando Sciascia, por ejemplo, habla de la «parroquia del estalinismo injertado con indefectible continuidad en el fascismo y el nazismo»—, ${ }^{255}$ podríamos citar este breve fragmento del ya recordado "¿También yo he sido estalinista?»: «Stalin [...] quería decir Stalingrado, la Rusia que detenía la marcha triunfal de Hitler y caía como una avalancha de hierro y fuego sobre Berlín [...] era la historia que empezaba con el desquite contra el nazifascismo que se había adueñado de Europa, aquella con la yo que me quería identificar, así como me identificaba con todo aquello que la anticipaba en el pasado. Stalin parecía representar el momento en que el comunismo se había convertido en un gran río, lejano ya del curso precipitado y accidentado de sus orígenes: un río en el que confluían las corrientes de la historia». ${ }^{256}$

254 Cfr. Traina, “'Con l'emozione dell'azzardo”. Appunti su Sciascia polemista», cit., p. 83: «En cambio en Fuego en el alma - libro que recoge las conversaciones con Domenico Porzio en el bienio 1988-1989-, Sciascia afirma que Robotti es "la persona más estúpida que he encontrado en mi vida". De hecho, "cuando un hombre que no ha traicionado es detenido por la policía del Estado, es torturado, le rompen la espina dorsal y sigue creyendo en el comunismo, es un estúpido" (cfr. Fuego en el alma. Conversaciones con Domenico Porzio, trad. Víctor Gallego, Mondadori, Barcelona, 1992).

255 Sciascia, «L'arroganza di Coppola» (1978), en Valter Vecellio (ed.), La palma va a nord, Gammalibri, Milán, 1982, p. 18.

256 Calvino, «Sono stato stalinista anch’io?», cit., pp. 196 y 198. 
Y en ese río confluye también, en La muerte de Stalin, la guerra civil española, a la que se dedican varias alusiones y al menos un par de páginas. Por lo demás, la Guerra de España está en el origen del destierro del protagonista, Calógero Schirò, zapatero de Regalpetra, cuyo cuñado se enrola en Norteamérica en las Brigadas Internacionales - casi un trayecto inverso al de Ventura- y envía a Italia una peligrosa carta de militancia interceptada por la policía fascista y por la cual pagará el zapatero comunista.

La misma guerra, luego, dará lugar a una serie de dudas (a las que no se daba crédito) acerca de la conducta de Stalin, cuyo prolongado pacto con los alemanes «le parecía una burla para él [Calógero], para todos sus amigos del destierro, para su cuñado y para todos los comunistas que habían muerto combatiendo por la República española»: “¿Cómo era posible que el camarada Stalin, el hombre que había hecho de Rusia la patria de la esperanza humana, siguiese declarando su amistad con los fascistas, mientras Europa gemía sangre, Francia estaba con su nuevo gobierno de alcantarilla y España con ese feroz general con cara de canónigo?». ${ }^{257}$

257 Sciascia, La morte di Stalin, cit., pp. 70-71. Cfr., para la situación española, Guy Hermet, La guerre d'Espagne, cit., pp. 224-228 y 238; y para la situación italiana, sobre todo en relación con la segunda posguerra, el reciente libro de Maurizio Degl'Innocenti, Il mito di Stalin. Comunisti e socialisti nell'Italia del dopoguerra, Piero Lacaita Editore, Manduria-Bari-Roma, 2005, que empieza precisamente con el acontecimiento histórico de la muerte de Stalin (pp. 9-16) y cita solo dos veces (pp. 57, 134) a Italo Calvino, «óptimo propagandista [...] en el periódico L'Unità a principios de 1952». Es una lástima que ese propósito riguroso, expresado en título y subtítulo, no traiga a colación, junto al caso de Robotti (pp. 125-126), por ejemplo, el caso de Sciascia y su evolución, o el de Calvino e intelectuales de diversa orientación (socialistas, liberales, etcétera), a propósito también de sus reacciones en los años cincuenta, entre la muerte de Stalin y el informe Kruschov. Cfr., por ejemplo, si no me equivoco, la ausencia de Norberto Bobbio y su «Ancora dello stalinismo: alcune questioni di teoria», aparecido en Nuovi argomenti, IV, 1956, pp. 1-30, ahora en la nueva edición de Politica e cultura, cit., pp. 241-267: "Un comunista a quien se le hiciera la observación de que Stalin era un tirano respondía, tenía que responder que la afirmación era falsa porque no era marxista (y, si bien se mira, no había otro argumento)», pues "en ningún texto doctrinal estaba escrito que, durante el período de la dictadura del proletariado, habría existido otro más o menos largo de tiranía, y ni siquiera que tal evento fuera posible. Por lo tanto, quien afirmaba que Stalin era un tirano formulaba, basándose en un argumento de autoridad, una proposición falsa. De nada servía oponer la experiencia»; e incluso "después de haber leído el informe Kruschov [que] era, en último análisis, el más despiadado mentís a las ilusiones revolucionarias» (pp. 246, 245, 241). Sugiere Ambroise, "Sciascia e la rivolta», pp. 170-171: "Hay que interpretar La muerte de Stalin como la historia desesperada de una negación: aceptar el informe 
Es cierto, como dice Ambroise, que después de Las parroquias de Regalpetra (1956) «la dimensión fantástica de Los tíos de Sicilia se colige del proyecto mismo de escribir "cuentos" y no una "crónica" ": ya no aparece "la firma de un testigo sino el recurso a lo dicho en primera persona, como para esconder la ficción». ${ }^{258}$ Pero también es cierto que tal ficción —no solo en primera persona, por lo demás cercana al decantamiento hacia la colectividad, a los otros, de Las parroquias de Regalpetra - todavía tiene en cuenta el testimonio, la crónica y, sobre todo, ciertas derivaciones de la memoria de algún modo reconducibles a ella, a partir de lugares comunes leídos en los periódicos: esos periódicos de los que desconfían los protagonistas de La muerte de Stalin y El antimonio y que tienden cada vez más a traducir en rápida crónica una historia que no se convierte dócil ni improvisadamente en crónica (y/o recuerdo).

Desde esta perspectiva, podríamos decir que Sciascia, como Calvino, no cree «en ninguna liberación, ni individual ni colectiva, que se obtenga sin el coste de una autodisciplina, una autoconstrucción, un esfuerzo», ni tampoco cree «en nada que sea fácil, rápido, espontáneo, improvisado, aproximativo», sino «en la fuerza de lo lento, calmado, obstinado, sin fanatismos ni entusiasmos». Con estas palabras Calvino se definía, no casualmente, «todavía [...] un poco estalinista». ${ }^{259}$

Desde este punto de vista, donde se refugia la crónica ínfima — que no es, desde luego, la de Las parroquias de Regalpetra ni, sobre todo, la de Breve crónica del régimen - ${ }^{260}$ y su rápida asimilación (el secretario fascista), acaso encuentra una justificación el final anticipado de El antimonio.

Kruschov sería, para un militante, negarse a sí mismo, negar la propia acción o revuelta. [...]. En los años de posguerra, Leonardo Sciascia, al experimentar la vida y sus contradicciones, es solidario con aquellos que querían que de la revuelta surgiese un proyecto revolucionario. Las parroquias de Regalpetra son expresión de tal solidaridad: la escritura está como injertada en la acción de los demás y, en este sentido, participa en ella. La voz narradora de Los tíos de Sicilia no rompe, claro está, el pacto». Pero cfr. cómo sigue el argumento en el texto.

258 Ambroise, Invito alla lettura di Leonardo Sciascia, cit., p. 88.

259 Calvino, «Sono stato stalinista anch'io?», cit., p. 203.

260 Cfr. de nuevo Tedesco, "Avevo la Spagna nel cuore”. Sciascia, la Sicilia, la Spagna», cit., y Perrone, «Sciascia, Vittorini e la Spagna», cit., pp. 243-244, 246-247, 248-249. Volveremos a aludir a Breve crónica del régimen en el capítulo siguiente. 
Anticipado respecto a los tiempos y desarrollos posibles de la «novela-biografía» sciasciana e incluso dentro de esa «autobiografía de la nación» de que habla Onofri; tal vez respecto a los tiempos y desarrollos de textos ajenos, esas grandes obras nacidas al amparo de la guerra, leídas y en buena medida amadas y presentes en el imaginario de El antimonio: desde La esperanza (1937), ${ }^{261}$ de André Malraux, a Por quién doblan las campanas (1940), de Ernest Hemingway, con su ritmo narrativo de "charla» civil, aunque épica. Una modalidad épica que supera las charlas para pasar el rato de los viejos y su recepción de las "cosas lejanas" y que, como precisaremos al principio del segundo capítulo, se despliega en el diálogo con Ventura y en otros pasajes del relato sciasciano, justamente dentro de ese ritmo de «charla» civil.

En el final anticipado de El antimonio, de todas maneras, Leonardo Sciascia da una pista falsa adicional, típica jugada de muchos finales sciascianos, donde casi siempre se tiende un puente hacia otro relato, otra posibilidad narrativa, como una continuación aún no realizada, una prosecución intuible que se trabajará con calma, con «lentitud» y obstinación, con el pasar de los años, como demuestra la colección de Los tíos de Sicilia y, en general, toda la obra sciasciana.

Después de estas cuestiones abiertas, volvamos para concluir a la evocación de la "ciudad lejana» con que termina El antimonio. Esa "ciudad lejana» que el ex minero ve en su futuro, veterano mutilado y premiado con un puesto de funcionario, no puede dejar de recordar al lector —en un texto tan lleno de ecos y remisiones internas- Madrid, lejana capital de la guerra, la resistencia y la memoria. Habría quizás que preguntarse si para una eventual continuación de El antimonio, antes de ese final, Sciascia no habría pensado en contar, sobre el fondo de los acontecimientos

261 Cfr. Traina, Leonardo Sciascia, cit., pp. 226-227: «El antimonio, en cambio, tiene un origen a la vez culto (una página de La esperanza de Malraux, libro que en 1966 Sciascia llegó a considerar «tal vez el más grande que se haya escrito en estos treinta años») y [como ya recordamos] "popular", es decir, recuerdos de algunos conocidos de Sciascia, uno de los cuales había ido efectivamente como voluntario fascista a la Guerra de España (y del cual encontramos noticias en el poco conocido cuento El soldado Seis)». Sobre este cuento, publicado en la revista Valbona, 1, 1958, pp. 3-5, véase lo que se dirá en el próximo capítulo. 
bélicos españoles y mundiales, la lucha antifascista, activa y/o pasiva, de su personaje, hasta la caída de Madrid en marzo de 1939 o más tarde, acaso yendo hacia adelante y cambiando el iter de Calógero Schirò en La muerte de Stalin.

Releamos, desde este punto de vista, el enfrentamiento final con el secretario fascista y la decisión de marcharse del protagonista:

El secretario fascista [...] quería que le contase episodios de la guerra; del general Bergonzoli, llamado "Barba eléctrica», era un fan, como si Bergonzoli fuese un jugador de fútbol o un torero. Yo le contaba cosas de Bergonzoli que había leído en los periódicos: aquella barba no la había visto nunca, y luego le contaba los episodios más atroces que había presenciado, cosas como para escupir sobre el fascismo. Se los contaba tal cual, sin poner ni una sola vibración de desprecio. Él escuchaba y su entusiasmo crecía. [...]

Un día me hizo llamar, porque la patria había respondido a sus solicitudes: la patria se había acordado de mí y me ofrecía un puesto de bedel en una escuela, pero los bedeles de la patria, o sea, los puestos de bedel de que disponía el Estado, estaban en las ciudades [...] Hacía falta, pues, que yo fuese a tomar posesión en una ciudad, a lo mejor cercana...

—No — dije—, es mejor en una ciudad lejana, fuera de Sicilia. Una ciudad que sea grande.

- ¿Y por qué? — preguntó el secretario, maravillado.

—Quiero ver cosas nuevas - dije. ${ }^{262}$

Es significativo que El antimonio, leído en su integridad e incluso como summa de un imaginario relativo al fascismo imperante, más allá de los ańos treinta y, sobre todo, del conflicto español, haya hecho pensar que Sciascia era víctima de la «habitual incontinencia polémica que a menudo le empuja a salirse de la trama, por la manía de dar bastonazos a todo y a todos, con una suerte de moralismo destructivo que no propone alternativas». ${ }^{263}$

Aparte del hecho de que se derriban puertas ya abiertas por el mismo Sciascia, como testimonia la mejor tradición crítica, desde Ambroise a

262 Sciascia, L'antimonio, cit., pp. 228-229. No nos olvidemos de un dato que en seguida retomaremos: el fútbol, que en los años treinta vio al equipo nacional italiano conquistar dos veces consecutivas la copa del mundo, ofreciendo triunfos deportivos al poder fascista que, por lo demás, los favorecía y celebraba casi como las victorias militares en Etiopía y España.

263 Michele Coco, «Jovine, Sciascia e la guerra di Spagna», Otto/Novecento, 3-4, 1982, p. 233. 
Traina ${ }^{264}$ no hay nada más lejano de un texto «abierto» — cerrado solo en la película inspirada en él, Una vida vendida - que, leído o releído fragmentariamente pero también en su integridad, puede ayudarnos a captar, en perspectiva, gran parte de la difícil y «abierta» relación de los narradores italianos con la Guerra de España, un connubio o un acuerdo poco armonioso de atracción-repulsión, de fascinación y miedo, maduración y regresión; un matrimonio en que la razón se casa con la pesadilla y cuyo divorcio se celebra en otras guerras, otras resistencias, otras memorias literarias y civiles de un siglo XX «herido de muerte», para siempre, comenzando por piras o incendios de sus ciudades más representativas.

264 Léase, al menos, a Ambroise, «Polemos», en Opere 1971-1983, cit., pp. VII-XXVIII, y consúltense de nuevo los artículos citados de Traina. 


\section{UN CUARTO DE SIGLO DE TRADICIONES PERDIDAS (1936-1960) Y UNA RÁPIDA INCURSIÓN}

1. «Y encima, me gusta charlar». Problemas de un discurso literario sobre la guerra civil espańola y concatenaciones del imaginario entre pasado y presente

En ciertas páginas de El antimonio, decíamos en el capítulo precedente, hay también un ritmo de "charla» civil, incluso épica, que tiende a superar las que mantienen los viejos para pasar el rato y su peculiar «recepción» de las cosas lejanas, legendarias, que están en cierto modo fundidas, indistintamente, en el tiempo (los paladines) y en el espacio (la guerra civil española); se trata de un ritmo que marca algunos diálogos entre Ventura y el protagonista, como el de la lejana, legendaria América, la gran América, libre, rica, civilizada, pero con «dos inocentes [...] ejecutados en la silla eléctrica [...], Sacco y Vanzetti». ${ }^{1}$ Y viene a la mente un Dos Passos recientemente traducido por primera vez al italiano, Davanti alla sedia elettrica. Come Sacco e Vanzetti furono americanizzati (Ante la silla eléctrica. Cómo Sacco y Vanzetti fueron americanizados), ${ }^{2}$ una contrainvestigación casi sciasciana — -por un tipo de justicia que tratase con el mismo criterio a pobres y ricos $[\ldots]$ por los derechos de los oprimidos contra los opreso-

1 Sciascia, L'antimonio, cit., p. 175.

2 Cfr. John Dos Passos, Davanti alla sedia elettrica. Come Sacco e Vanzetti furono americanizzati (1927), ed. Piero Colacicchi, Spartaco, Caserta, 2005, pp. 9 y 37. 
res»-, para ubicar el suceso en su contexto, los Estados Unidos de los años veinte, entre el temor al contagio revolucionario comunista y el disgusto por los que estaban llegando del sur de Europa.

Pero, más que John Dos Passos, posible origen de un ritmo narrativo de "charla» épica y civil, es Ernest Hemingway quien ha casi teorizado tal ritmo en distintos lugares de su producción, y, cómo no, en la célebre y ya citada Por quién doblan las campanas, donde - para Sciascia, Horas de Espa$\tilde{n} a$ (1989)—3 hay "páginas inolvidables [...] aquellas que llamaría periodísticas»: periodísticas no porque se amolden fácilmente a la visión de los periodistas — que después de todo es la de los viejos-, de los que el protagonista de El antimonio ha aprendido a desconfiar precisamente durante la Guerra de Espańa, sino porque verdaderamente saben captar, con una cierta inmediatez a caballo entre el artículo, el reportaje o el diario público, a personajes como "André Marty, el ruso Karkov, el general húngaro». ${ }^{4}$

En este sentido, el Sciascia de Horas de España (1989) no defiende solo su propia actitud, sino también el riesgo y el compromiso de una literatura que se mide con la historia in fieri. Sciascia no responde precisamente a la interpretación hemingwayana que en los mismos ańos propone Sergio Perosa, por ejemplo, en un artículo de 1986, «La memoria y los tiburones», donde juega brevemente con la oposición entre «experiencia» $\mathrm{y}$ «memoria de la experiencia»:

3 Sciascia, Ore di Spagna, cit., p. 62.

4 Ib. A este propósito y, más en general, para la idea que sostiene este epígrafe, es necesario remitir en seguida a las densas y concluyentes páginas de Bartolomé Bennassar, "Quand l'imaginaire transcende la guerre civile», en La guerre d'Espagne et ses lendemains, Perrin, París, 2004; así como col. Tempus, 2006, pp. 481-484: “Cómo — se pregunta Claude Pichois - una guerra, es decir la muerte, las mutilaciones, la injusticia, puede devenir literatura? ¿Cómo la nada puede hacerse vida?». La Guerra de España impone esta cuestión. [...]. El lenguaje lírico, el de la epopeya, consigue gracias a una sorprendente hazaña conjurar el horror sin omitirlo. Ello no es privativo de la poesía. La esperanza de Malraux y Por quién doblan las campanas de Hemingway son obras líricas. Por tanto, estos dos libros no hacen trampas ni con la verdad ni con la muerte. Hemingway no reserva las atrocidades a las tropas franquistas; narra también la masacre de los terratenientes de un pueblo a manos de una multitud encolerizada. Y aun señalando su repugnancia por los manipuladores procedimientos de los comunistas, reconoce que eran los únicos que podían dar la victoria a la República gracias a la creación del ejército popular. No se hace ilusiones, como su personaje Karkov, que no es otro que el doble literario de su amigo Koltsov, corresponsal de Pravda en Madrid y autor de Journal espagnol, detenido en Moscú el 12 de diciembre de 1938 y eliminado». 
[...] el riesgo es que cuanto más escribe [Hemingway] a partir de una experiencia inmediata, más débil resulta artísticamente. En las obras posteriores a 1930, Hemingway parece anular o reducir demasiado aquella distinción entre reportaje y narrativa que en un principio consideraba esencial para el éxito de esta última. [...]. Ahora tiende a olvidarla, a trabajar sobre la vida demasiado cerca de ella: y en este sentido se explicaría la calidad relativamente inferior, con respecto a las pruebas precedentes, de novelas como Tener y no tener, Por quién doblan las campanas y Al otro lado del rio y entre los árboles. ${ }^{5}$

En definitiva, el triunfo es, desde el comienzo, para la "“emoción recordada con tranquilidad" "; o sea, leyendo provocatoriamente El antimonio, para aquella experiencia que (no) se hace dulce recuerdo, en la tranquilidad de un regreso (imposible). A este propósito, acordémonos de cuanto se ha dicho sobre la memoria, el miedo, el fuego, y también de cuanto se ha sugerido acerca de la contigüidad de El antimonio con una cierta dimensión periodística sciasciana. Por último, prestemos atención al hecho de que estamos hablando de ritmo narrativo y no de las ideas que este vehicula o de las imágenes que usa.

Para entendernos: en El antimonio, en ciertos momentos, se advierte casi un diálogo, una "charla» al modo de Hemingway, pero las imágenes, las ideas pueden ser otras, derivadas más bien, como se ha visto, de Orwell o de Malraux, o bien de un tejido novelesco y de un horizonte simbólico de los que Sciascia parece nutrirse con mayor asiduidad. Piénsese también, en la misma línea, en la evocación de los «anarquistas»: "cada uno de ellos se sentía un poco Jesucristo», ${ }^{6}$ sugiere El antimonio; "—¿Cristo? -Un anarquista que ha triunfado", se lee en La esperanza. ${ }^{7}$ Por lo demás, Dos Passos equipara a los anarquistas italianos con los primeros cristianos, haciendo de Sacco y Vanzetti — con un filtro religioso chocante, pero en concordancia con el periodismo liberal y militante que habla de «justicia crucificada" - dos mártires plenamente insertados en el mito de fundación de América, de la ex ciudad perfecta al otro lado del Atlántico.

Dicho esto, seguramente más que Dos Passos, Hemingway fue leído, entendido y apreciado por Sciascia, también por lo que respecta al heroís-

5 Sergio Perosa, "La memoria e gli squali», en Sergio Perosa (ed.), Hemingway a Venezia, actas del congreso (Fundación Cini, isla de San Giorgio Maggiore-Venecia, 24-25 de noviembre de 1986), Olschki, Florencia, 1988, p. 214.

6 Sciascia, L'antimonio, cit., p. 210.

7 Malraux, L'Espoir, cit., p. 43. 
mo, al amor, su entrecruzarse más o menos enfático, más o menos lejano de un tono periodístico, de una restitución inmediata o casi de los acontecimientos y de los hechos. A este propósito, recordemos también lo que se dijo sobre el cine y sobre la vieja cuba hollywoodiana.

En la novela hemingwayana, por lo demás, podemos encontrar ese ritmo narrativo de "charla" épica y civil incluso cuando una mujer, Pilar, habla de sí misma, de amor, de ser hermosa o fea, en una pausa que parece suspender el tiempo del mundo y de la guerra. Y podemos apreciar la gran eficacia de tal ritmo en un diálogo de pocas frases, llevado al exergo de este trabajo, que vale la pena retomar, ya sea en inglés o en italiano, porque da la entonación, a la vez problemática y provocatoria, de un discurso literario sobre la guerra civil espańola; una guerra en la que la prisa, la acción del héroe, Robert Jordan, el Inglés, puede ser suavizada por la calma, por la plática de una mujer, Pilar:

Furthermore, I like to talk. It is the only civilized thing we have. How otherwise can we divert ourselves? Does what I say not hold interest for you, Inglés?

Y encima me gusta charlar. Es la única cosa civilizada que nos ha quedado. ¿Cómo podríamos distraernos, si no? ¿Acaso no te interesa lo que te digo, Inglés?8

En la primera edición italiana (1948), a cargo de Maria Napolitano Martone, verosímilmente manejada por Sciascia, "charlar», que viene de to talk en su acepción de "hablar, conversar», más que de "cotillear», puede ser vocablo noble, civil e incluso épico, aunque sin excesivas florituras enfáticas o didascálicas, filtradas, con ironía, de ese «charlar» que implica también locuacidad, hablar por hablar. Por lo demás, de manera no precisamente casual, en este "charlar» compuesto que estamos considerando, el personaje extraordinario que es Pilar se dirige a Robert Jordan "como si hablase a unos alumnos; casi dando una conferencia».?

Precisamente por su ambivalencia, tal vocablo abre la puerta al divertimento y al compromiso del texto, plasmados uno junto a otro, rápidamente, casi como en un artículo: "Furthermore, I like to talk. It is the only

8 Ernest Hemingway, For whom the bell tolls, The Continental Book Company, Estocolmo-Londres, 1946, p. 103; Ernest Hemingway, Per chi suona la campana, Mondadori, Milán, 1996, p. 107. (Por quién doblan las campanas, trad. Lola de Aguado, Planeta, Barcelona, 1997).

9 Ib., pp. 103 y 107, respectivamente. 
civilized thing we have». Y ese "furthermore» puede también significar «es más»; aquel es más que en algunos momentos ha sido —y será todavíanuestra cifra estilística a la hora de apreciar la problemática complejidad de Sciascia, de El antimonio y de la literatura de la Guerra de Espańa, desde los años del conflicto en adelante.

El sustantivo derivado de "charlar», "charla», ya usado en el capítulo precedente, puede por tanto significar — dejando a un lado al Vittorini más lírico y alusivo - conversación, discurso, viniendo muy al caso. Sin caer necesariamente en el melodrama ni en la retórica, o en la pluralidad onomatopéyica implícita (a menudo solo negativamente) en el verbo "charlar», una "conversación» puede servir para tomar la medida a un mundo a la vez feo y hermoso, a partir de un cuerpo que expresa ya, significativamente, esa ambivalencia: "iSabes lo que significa ser fea durante toda tu vida $y$, por dentro, sentir que eres hermosa?». ${ }^{10}$

Tal dualidad, en fin, es también la dualidad de un conflicto, de un mundo, e incluso su potencial y literaria superación en el ámbito de la calma, de la charla de Pilar: "Irme, qué va. Aquí estoy muy bien». ${ }^{11}$ Porque una conversación amistosa, agradable, puede también dar el tono de un discurso sobre la guerra civil española, como en el caso de Sciascia. Recuérdese cuanto se ha dicho sobre el origen de El antimonio, que, en ese sentido, no resulta tan lejano de Por quién doblan las campanas ni del Hemingway periodista y entrevistador que la anima.

Volviendo al citado juicio de los años ochenta sobre Hemingway y Malraux, propiciado (también) por un Sciascia al que preocupa la poca consistencia y credibilidad de la literatura dedicada a la guerra civil espańola entre los jóvenes, con quienes admite en parte lo anecdótico o lo pintoresco, si no lo falso, de ciertas páginas de esos dos grandes escritores-testigo, ${ }^{12}$ Gabriele Ranzo acaba extremando y distanciando la postura de Sciascia, retrotrayéndola con un célebre y duro comentario sobre Hemingway de Aldo Garosci que se remonta a 1959 y, por tanto, a una época en

10 Ib., pp. 102 y 106, respectivamente.

11 Ib., pp. 103 y 107, respectivamente.

12 Sciascia, Ore di Spagna, cit., p. 62. 
la que, como veremos, la complicidad de Leonardo Sciascia con Ernest Hemingway era todavía más significativa.

El resultado y el riesgo de esta interpretación es aislar primero y confinar después, de hecho, el texto literario de El antimonio casi completamente en el ámbito de las variaciones historiográficas e incluso de una estrategia, en cierto modo, "partisana». ${ }^{13}$

En realidad creo que el juicio de aquellos jóvenes se puede en buena medida suscribir, sobre todo porque las obras que más han llegado al gran público, las de Hemingway y Malraux, prácticamente no sirven para entender la dimensión de la guerra civil española que debería estar más al alcance de un novelista, aquella dimensión entre lo público y lo privado en la que se mueven las pequeñas historias individuales, que luego confluyen, determinando en parte su curso, en la gran Historia.

No obstante su pretendido realismo, los libros de Malraux y Hemingway quedan lejos de la realidad de la guerra civil y de Espańa. Los personajes de La esperanza de Malraux son un pretexto para las reflexiones del autor sobre entes abstractos como la Revolución y la Guerra, más que la representación de auténticos hombres, auténticos españoles —o al menos auténticos franceses - inmersos en aquel suceso. Los personajes de Por quién doblan las campanas — quizá el mayor vehículo de conocimiento de la Guerra de España para la opinión pública mundial— son lo más lejano de la realidad espańola. "No son - ha escrito Aldo Garosci- ni obreros ni campesinos: son ladrones de caballos, gitanos, toreros más o menos frustrados [...]. Y el héroe, a pesar de su moderna aspereza, tiene algo de Davy Crockett.

[...] Como es sabido, Malraux y Hemingway fueron testigos activos de la Guerra de España. Sciascia, por obvias razones generacionales, no. Y sin embargo El antimonio [...] rezuma intuiciones extraordinarias y muestra una capacidad de atrapar aspectos destacados de aquel suceso absolutamente superior a la de los otros dos autores más famosos, además de testigos directos. Y esto, aun siendo a su vez demasiado dependiente de la literatura, que prefería, al menos como fuente de inspiración, a la historiografía. ${ }^{14}$

Sciascia, a diferencia del historiador de profesión, se situa más allá de los “"exotismos" que estaban bien para el público norteamericano»" ${ }^{15} \mathrm{y}$ tiende a salvar, con respecto al historiador y al anglista, el caracter testi-

13 Ranzato, gran especialista en la guerra civil española, fue invitado a hablar sobre Sciascia en un congreso dedicado a las relaciones del escritor siciliano con España y promovido por los Amigos de Sciascia, así como por su fundación.

14 Gabriele Ranzato, "Sciascia e la guerra civile spagnola: Sciascia tra verità storica e verità letteraria", en Natale Tedesco (ed.), Avevo la Spagna nel cuore, La Vita Felice, Milán, 2001, pp. 211-212.

15 Ib., p. 212. 
monial e inmediato de la literatura de Hemingway (y de Malraux) ${ }^{16}$ sobre la Guerra de España, si bien no depende directa ni únicamente de aquella literatura ni de aquella tradición narrativa y su ritmo épico-civil.

¿Por qué? Porque Leonardo Sciascia intuye que, en los años próximos a la Guerra de España, intentar asimilar aunque solo sea un cierto ritmo narrativo de "charla» épica y civil significa asimilar «de cerca» y en su inmediatez la problemática complejidad de una historia in fieri, difícil de contener, de representar, que no se convierte dulcemente en recuerdo para ninguno, ni siquiera para monstruos sagrados como André Malraux o Ernest Hemingway. En fin, podríamos incluso sugerir que las críticas dirigidas a este último por historiadores y anglistas son, para Sciascia, una prueba del riesgo asumido por el escritor y de su compromiso, de su engagement, en relación con una realidad compleja y sin resolver, la de la guerra civil española, representable también mediante «tipos alegres que hacen saltar puentes» ${ }^{17}$ (llevándolo al extremo, se podría pensar en jAgáchate, maldito! (1971) de Sergio Leone, inclinado como Hemingway a contar, a partir de guerras y revoluciones, acontecimientos particulares más que historias corales, empresas individuales más que movimientos de masas). ${ }^{18}$

Es más, Sciascia sabe muy bien que en la guerra se continúa viviendo y que «charlar» forma parte de ella, es la guerra, la vida en la guerra, en la revolución: y en la vida hay mujeres feas y hermosas, esposas o mujeres de la soldadesca (mujeres que portan "dentro el mal de aquella guerra", dice Sciascia), ${ }^{19}$ y además trenes, caballos, ladrones, alcohol, pueblos y paisajes más o menos exóticos. En fin, hay muchas palabras y cosas, tanto en inglés como en español o en italiano. Y contrariamente a lo que piensan algunos extravagantes inventores con quienes se tropieza el Gulliver de Jonathan Swift en la Academia de Lagado, cada palabra que pronunciamos en la guerra nos prolonga la vida y tiende a dilatar la percepción y la naturaleza de las cosas, de cada cosa. ${ }^{20}$

16 Cfr. en este sentido Paul Nothomb, Malraux en Espagne, pról. Jorge Semprún, Phébus, París, 1999, pp. 9-41.

17 Hemingway, Per chi suona la campana, cit., p. 21.

18 Francesco Mininni, Sergio Leone, Il Castoro/L'Unità, Milán, 1995, pp. 33 y 99.

19 Sciascia, L'antimonio, cit., p. 198.

20 Cfr. Fabrizia Ramondino, Guerra d’infanzia e di Spagna, Einaudi, Turín, 2001, p. 49: "Creían, mis padres, darme dos nombres para cada cosa, y no sabían, en cambio, que me daban dos cosas para cada cosa. [...]. Y ya que, por tener distintos nombres, cada cosa no era una sola, sino dos, pudo luego cada cosa convertirse en muchas juntas». 
Malraux, por un lado, y Hemingway, por otro, aceptan el desafío quizá más que otros y, hasta cierto punto, vencen, porque a fin de cuentas crean una "charla» legendaria y a la vez aportan una "dimensión» novelesca del conflicto y del mundo, constituyendo de hecho modelos narrativos insuperables, inspirados como están en una épica y en una vitalidad todavía decimonónicas, clásicas, con su concepción también clásica de la muerte — que comprende una vez más «la fórmula de Malraux [...], la muerte es lo que "transforma la vida en destino" "— ${ }^{21}$ y su consolación heroica, adquirida en tal sentido sobre todo por Robert Jordan en Por quién doblan las campanas (1940) (qué distinto, en cualquier caso, resulta el horizonte plural, colectivo de Malraux y también el del héroe de The Adventures of a Young Man (Aventuras de un joven) (1939) de Dos Passos, Glenn Spotswood). Y semejante consolación, frente a la derrota de la República y, en sentido absoluto, del mundo, hace que «una de las novelas más bellas del siglo XX", Por quién doblan las campanas, haya sido a menudo despachada, en Italia pero no solo, como fruto de una actitud vitalista y nihilista, retórica e incluso crípticamente fascista. ${ }^{22}$

No para Sciascia, quien, aún antes de publicar El antimonio, se pregunta lúcidamente en La sexta jornada, de 1958, por el inmediato y significativo lazo entre literatura y guerra civil española: «¿no estaba la retórica más bien en las cosas que en el poeta? [Sciascia llama aquí poeta al escritor en general, desde Lorca hasta Hemingway]. O mejor aún, ¿lo que nos pare-

21 Discute a propósito Gilles Deleuze, «Sur la mort de l'homme et le surhomme», en Foucault, Les Éditions de Minuit, París, 1986 (reed. col. Reprise, 2004, p. 138), que sugiere además la continuación sartriana. Pero, simplemente releyendo El muro, y por permanecer dentro de nuestro horizonte español, en la recopilación homónima de 1939 —aunque escrito y publicado antes, precisamente el ańo de La esperanza, en la Nouvelle Revue Française, julio de 1937 — parece que la postura de Sartre es ya antagonista y crítica con respecto a la de Malraux. Cfr., no obstante, Jean-Paul Sartre, "Le mur», en Le Mur, Gallimard, París, 1939 y 1958, pp. 11-34; e Il muro, Einaudi, Turín, 1947 y 1963, pp. 9-31. (El muro, trad. Miguel Salabert, Alianza Editorial, Madrid, 1988).

22 Franco Cordelli, La democrazia magica. Il narratore, il romanziere, lo scrittore, Einaudi, Turín, 1997, p. 96. No así Sciascia, como precisaremos en el texto, ni tampoco Mario Rigoni Stern —otro gran escritor de la generación de Sciascia, nacido el mismo año, 1921-, quien sugiere honestamente: "En Por quién doblan las campanas identificamos incluso, en algún personaje, el comportamiento de conocidos que habían sido partisanos: la vida se convertía en literatura y la literatura en vida». Cfr., a este propósito, Mario Rigoni Stern, "Quando scopersi Hemingway», en Tra due guerre e altre storie, Einaudi, Turín, 2000, p. 212. Distinta opinión, en Oreste del Buono — nacido en 1923 - I peggiori anni della nostra vita, Einaudi, Turín, 1971, pp. 117-118. 
ce retórica, lo era en el momento en que se hacía?». La respuesta, puntual y segura, no tarda en llegar: «Vistas en condiciones de serenidad y desapego, ciertas formas de dolor humano - en el cuerpo, en el llanto, en las palabras del hombre- son enfáticas. También es enfático el heroísmo; y el amor». ${ }^{23}$ Por lo demás, Sciascia es bastante claro por lo que respecta a nombres de "poetas» que, cercana la guerra, fueron los primeros en revelar "en las cosas" $\mathrm{y}$ "en el momento en que se hacen» un mundo que «hoy» puede aparecernos como retórico, con mucho énfasis, heroísmo y amor. De hecho, tras haber reconocido «a la guerra civil española [...] la revelación de un mundo, del mundo", observa que "la primera revelación surge del hecho de que García Lorca había sido fusilado por los franquistas, y que Dos Passos, Hemingway y Chaplin estaban de parte de la República». ${ }^{24} \mathrm{Y}$ no es de extrañar que se evoque a Chaplin, porque leyendo los nombres de aquellos «poetas» debemos pensar, con Eisenstein y la mejor tradición crítica chapliniana, que Charlie Chaplin trabaja entre 1937 y 1940 en El gran dictador, estrenada en octubre de aquel año, precisamente, propiciando una admirable transición en el universo de Charlot: «lo que le sucede ya no pertenece a un condición existencial absoluta, pues es determinado por una modificación de la historia, que catapulta el mundo en el horror». ${ }^{25}$

Obviamente, entender, como hace Sciascia, la antirretórica de cierta novela norteamericana y captar el ritmo narrativo de "charla» épica y civil de Hemingway no significa necesariamente querer y poder suscribirlos, siempre y en absoluto. Porque a veinte años de distancia del final del conflicto español, asimilar el ritmo narrativo de quien además había revelado, antes que nada, un mundo, el mundo, es más difícil, y no solo por el cambio de coordenadas del género novelesco en el siglo XX, que, desde Svevo hasta Moravia, desde Musil hasta Broch, rechaza cualquier consolación heroica. ${ }^{26}$

23 Sciascia, "La sesta giornata», Officina, 7, 1958; luego en AA. VV., La noia e l'offesa, Sellerio, Palermo, 1976, p. 162. Cfr. también lo que dice en tal sentido Lisa Foa, $\grave{E}$ andata così, Sellerio, Palermo, 2004.

24 Sciascia, «La sesta giornata», cit., p. 158.

25 Giorgio Cremonini, Charlie Chaplin, Il Castoro/L'Unità, Milán, 1995, p. 79. Pero cfr. las últimas páginas de Serguei Mijailovich Eisenstein, "Charlie the Kid», en Eisenstein, Bleiman, Kosinzev, Iutkevich, La figura e l'arte di Charlie Chaplin, Mondadori, Milán, 1959, pp. 161-164.

26 Cfr. de nuevo lo que sugiere, en síntesis, Franco Cordelli, al comienzo de La democrazia magica. Il narratore, il romanziere, lo scrittore, cit., p. 9: "mientras que el siglo XIX, desde Flaubert hasta Hemingway (Por quién doblan las campanas), sostiene que existe la 
Asimilar dicho ritmo narrativo es difícil, en primer lugar, por el "eclipse de la democracia», ${ }^{27}$ por el fuerte estancamiento histórico de una "democracia asesinada ${ }^{28}$ por las grandes potencias, que luego a duras penas se han reencontrado con la propia, haciendo la vista gorda respecto a ese estancamiento durante la guerra fría.

En la primera mitad de los años sesenta, Franco está siempre al frente; una presencia ya no tan fuerte pero clara, que se suele oponer, ridiculizándola acaso, ${ }^{29}$ al bloque comunista de la Unión Soviética filtrado por las revelaciones de Kruschov. Prueba de ello, por ejemplo, es una boutade de El camarada don Camilo, película de Luigi Comencini de 1965, donde el célebre personaje inventado por Giovannino Guareschi contesta el proyecto político de hermanamiento de Brescello con un pueblo ruso, considerando tal práctica como «una cuestión que atañe solo a la moral y al buen sentido", y reformulando la propuesta del alcalde comunista Peppone en los siguientes términos: «Si yo estuviera en su lugar, señor alcalde, y el Generalísimo Franco nos regalase un toro de lidia o una partida de castańuelas y pretendiese hermanar nuestro pueblo con Madrid, ¿̨usted cómo se lo tomaría?» La "charla», aquí, se vuelve talmen-

posibilidad de que esta misma idea [creer de modo paradójico, no cristiano] puede ser fuente de sacrificio y de heroísmo, de un incremento de vitalidad por consiguiente, el siglo XX, desde Svevo hasta Moravia, desde Musil hasta Broch, rechaza cualquier consolación heroica; más aún, la detesta».

27 Gabriele Ranzato, L'eclissi della democrazia. La guerra civile spagnola e le sue origini (1931-1939), Bollati Boringhieri, Turín, 2004. (El eclipse de la democracia: la guerra civil española y sus origenes, 1931-1939, trad. Fernando Borrajo, Siglo XXI, Madrid, 2006). Del mismo cfr. también la excelente síntesis ofrecida en La guerra di Spagna, col. XX Secolo, Giunti-Casterman, Florencia, 1995.

28 Jean-François Berdah, La démocratie assassinée. La République espagnole et les grandes puissances 1931-1939, Berg International Éditeurs, París, 2000 (La democracia asesinada: la República española y las grandes potencias, 1931-1939, trad. María José Furió, Crítica, Barcelona, 2002).

29 Volver rídiculo (también ridiculizar) es el primer, elemental movimiento de la conciencia irónica que comienza a distenderse, a delimitar el peligro y a juguetear con él: «La ironía, que ya no teme las sorpresas, juega con el peligro. El peligro, esta vez, está en una jaula; la ironía va a verle, le imita, le provoca, le pone en ridículo, le entretiene para su recreo». Cfr. Vladímir Jankélévitch, L’Ironie, Flammarion, París, 1964, y en col. Champs, 1979 y 1987, pp. 9-10 (La ironia, trad. Ricardo Pochtar, Taurus, Madrid, 1986), que es bien consciente de que «el tiovivo, a decir verdad, puede dar pocas vueltas [como en el caso de la política de distensión]. Por tanto, el espíritu de ironía es precisamente el espíritu de la distensión, y se aprovecha de la menor tregua para reanudar sus juegos». 
te anecdótica que se nutre solo de exotismos, se convierte (casi) toda en locuacidad, cayendo además en la charla un tanto onomatopéyica (y quizá en la acepción menos noble de charlar); pero sigue siendo, en cualquier caso, significativa.

Pocos años antes, a la altura de la citada Sexta jornada, Sciascia puede escribir:

Salvando a Franco de la debacle que le esperaba, los Estados Unidos, además de haber faltado a la gran promesa de Roosevelt, provocan hoy desconfianza y reacción en el antifascismo europeo, mostrando que el diagnóstico marxista (diríamos estalinista) del fenómeno fascista sigue siendo sustancialmente exacto. ${ }^{30}$

Por un lado la guerra fría, la (actualísima) desconfianza hacia los Estados Unidos por parte del antifascismo europeo; por otro, el "fantasma» ${ }^{31}$ de Stalin, fallecido en 1953 (y peculiar "aparecido" en la primera edición de Los tíos de Sicilia, 1958); en el centro, el Generalísimo rondando los setenta ańos. Elementos todos que hacen aparecer como una suerte de "frontera» la democracia de los países en que se puede "charlar» sobre la guerra civil española: una especie de limbo espacio-temporal donde a los supervivientes, camaradas, testigos, escritores, directores de cine, a todos los que no olvidan, no les queda quizá sino saborear, como los demás, «un sueño para turistas o la leyenda de la guerra civil», como se oye decir a Diego-Carlos (Yves Montand) — exiliado español que vive en el París de los ańos sesenta - en una invectiva a mitad de La guerra ha terminado (1966), de Alan Resnais: ${ }^{32}$

¡Ah, la triste España, la España heroica! [...]. España se ha convertido en la buena conciencia poética de toda la izquierda, un mito para antiguos combatientes. España no es más que un sueńo para turistas o bien la leyenda de la guerra civil.

30 Sciascia, «La sesta giornata», cit., en AA. VV., La noia e l'offesa, cit., p. 158.

31 Pierre Broué, Staline et la Révolution. Le cas espagnol, Fayard, París, 1993. Aunque cfr. sobre todo el reciente libro de Daniel Kowalsky, La Unión Soviética y la guerra civil española, Crítica, Barcelona, 2004.

32 Cfr. Marcel Oms, La Guerre d'Espagne au cinéma, pról. Pierre Broué, Éditions du Cerf, París, 1986, pp. 235 y 197 (Guerra civil y cine, Fernando Torres, Valencia, 1985), donde cita otro pasaje: «España ya no es el sueño de 1936, sino la verdad de 1965, aun cuando parezca desconcertante. Han pasado treinta ańos y me joroban los viejos combatientes». Cfr., sin embargo, el guión de la película por Jorge Semprún, La Guerre est finie, Gallimard, París, 1966. 
En fin, a la trivialización de una leyenda, de la que ahora ya se charla cada vez más en vano, con la "sensación de déjà-vu» que atenaza a Diego-Carlos en las reuniones, y que parece asociarse al turismo o al amor sin ninguna mesura (verbal, ética, política), hay quien responde trabajando sobre la forma narrativa, cinematográfica y novelesca, o bien intentando, experimentando una nueva "medida» del relato y de la memoria, precisamente en los mismos años sesenta que abre El antimonio.

En la Francia de aquellos años, Alain Resnais, autor de un documental sobre Guernica (1951) —a medio camino entre el cuadro y la realidad y en la línea de la nouvelle vague, de la que es una de las expresiones más autorizadas y comprometidas-, ensaya, con Jorge Semprún, en La guerra ha terminado (1966) una «medida» para analizar un personaje en profundidad, trabajosa, fatigosamente, de manera no-deltodo-clara. Un personaje protagonista cuyo papel de narrador interno no sea vehículo poderoso, heroico, de leyendas, remembranzas, nostalgias, sino que, al contrario, tienda a denunciarlas en cuanto tales, colmando con esfuerzo - en su trayectoria formativa, con dudas políticas, amorosas, y un final significativamente abierto- el foso que los dilatados tiempos de la memoria, aquellos más estrechos de la acción (imposible, a fin de cuentas) y las dolorosas modificaciones de la historia han abierto en la vida de un hombre y de un mundo, o, a secas, en la vida del hombre y del mundo; es decir, también en aquella buman condition que no coincide con una condición existencial absoluta sino que constituye precisamente su superación, como sugeríamos en el capítulo precedente.

A partir de perspectivas históricas distintas, una anclada en el pasado de la guerra, segunda mitad de los años treinta, otra en el presente de la película, primera mitad de los sesenta, Sciascia, Semprún y Resnais, intelectuales ciertamente distintos pero de la misma generación, entregan a Europa y al mundo —aparte aniversarios más o menos evidentes: veinte años del final, treinta del inicio del conflicto- un nuevo modo de pensar, escribir, filmar la guerra civil española y su herencia en nuestros días, en cuanto — siempre en palabras de Sciascia— ${ }^{33}$ "acontecimiento nodal [...] clave en la historia reciente del mundo».

33 Sciascia, «La sesta giornata», cit., en AA. VV., La noia e l'offesa, cit., p. 158. 
Aquella suerte de «frontera» desde la que viven la centralidad y la actualidad del evento bélico español Sciascia, Semprún, Resnais y tantos otros es, a fin de cuentas, una preciosa y para nada obvia inversión de perspectiva epistemológica: la memoria recupera el país al que todos fueron a combatir - y donde siguen yendo en cierto modo, caso de Diego- y, de rebote, lo hace revivir en otros países casi como en un proceso de exorcismo democrático, que pasa por una nueva «medida» y memoria del mundo a través de formas narrativas experimentales como la novela y el cine. Desde este punto de vista, El antimonio nos parece verdaderamente un experimento, en varios niveles, que no ha de infravalorarse, al igual que $L a$ guerra ha terminado, aun cuando esté anclado en un esquema narrativo más tradicional, lejano de la relectura que de la guerra civil española ofrece en los mismos años, en el ámbito del nouveau roman, Claude Simon en Le Palace (El palacio) (1962).

Un proceso cultural similar de exorcismo democrático encuentra terreno abonado en los años sesenta, partiendo igualmente, de un modo problemático, de otras experiencias y de otros conflictos, quizá incluso abiertos. Del mismo año de El antimonio es El soldadito (1960) de JeanLuc Godard, que sin embargo fue bloqueado por la censura francesa y solo pudo verse en las salas en 1963. Bruno Forestier (Michel Subor) trabaja en esa isla-«frontera» que es Suiza, mayo de 1958, para un grupo de derechas pero para él, que no obstante es joven, «el tiempo de la acción ha pasado». Piensa: "Me he vuelto viejo». Es la época de la guerra de Argelia (19541962) y, más concretamente, del pronunciamiento militar de Argel, que tuvo lugar en mayo de 1958. A De Gaulle, elegido presidente de la V República ese mismo año, la Asamblea Nacional le concede plenos poderes. Tan cargado ambiente está "enmarcado» en la película, al comienzo y hacia el final, por dos rápidas pero significativas evocaciones de la guerra civil española: «el saludo de los republicanos españoles» («es hermoso, porque no es malvado») y «la impresión de estar derrotado»: "Hacia 1930, la gente joven tenía la Revolución. Por ejemplo, Malraux [...]. Nosotros no tenemos ya nada. Ellos tenían la Guerra de España, nosotros no tenemos siquiera una para nosotros. Aparte de a nosotros mismos [...], no tenemos nada». En estas líneas, encerradas en la soledad del soldadito (la misma soledad que circula en La guerra ha terminado y en parte, pero de manera diferente, en El antimonio), la revolución y la Guerra de Espańa de Malraux (y sus personajes) no son entidades abstractas ni exóticas; antes bien, 
son percibidas concretamente como ocasiones auténticas, plenas, a las que aferrarse para renovar la aproximación vacía de una investigación históri$\mathrm{ca}$, política, humana; una investigación que entre los ańos cincuenta y sesenta parece naufragar en el mar de los intereses superiores de cada nación (empezando por la francesa), pero que intenta de todos modos un cierto exorcismo democrático, recuperando a España como memoria del mundo (o cuando menos de Europa) y proyectándola, casi circularmente, sobre Francia, Suiza - Italia-y Argelia. ${ }^{34}$

En los ańos setenta, el mismo proceso de exorcismo juega todavía su papel hasta que, en el decenio siguiente, parece desaparecer junto a la guerra fría, con la caída lenta pero definitiva de la Unión de Repúblicas Socialistas Soviéticas y el empuje — cada vez más evidente - de la cultura del narcisismo ${ }^{35}$ y las desestabilizadoras opciones apolíticas, ahistóricas, de las nuevas generaciones.

El internacionalismo, que es la respuesta al imperialismo entre los siglos XIX y XX, supera las fronteras del país (todavía) en guerra, España, para vivir en otro lugar la democracia, no la guerra. Porque la herencia de

34 Un cierto exorcismo democrático necesario, porque son ciertamente los años en que «los "intereses superiores de la nación" explican asimismo el sofocamiento de las actividades políticas propias de los exiliados. El caso español es, aquí también, particularmente elocuente. [...]. Tras múltiples tentativas, Franco logra finalmente en agosto de 1954 que el ministro del Interior (François Mitterand) ordene la supresión de la emisora clandestina de Radio Euskadi. A continuación, los exiliados españoles se convierten en moneda de cambio en la cuestión argelina. [...] Como observa un miembro del gobierno franquista, Francia puede ahora comprender mejor el problema de los exiliados porque ella misma ha de enfrentarse con los argelinos huidos en Túnez. En junio de 1959, por primera vez, el primer ministro francés (Michel Debré) recibe al embajador de España y concuerdan sobre la necesidad de una más estrecha colaboración entre la policía y los servicios secretos de ambos países. Una nota del Quay d'Orsay precisa: "Es de temer, en concreto, que los rebeldes argelinos encuentren asilo y complicidad en España"». Cfr. Gérard Noiriel, Réfugiés et sans-papiers. La République face au droit d'asile XIX'-XXe siècle, Calmann-Levy, París, 1991 (reed. Hachette Littérature, col. Pluriel, París, 1998, p. 215). Para los diálogos de El soldadito, cfr. Cahiers du Cinéma, 119, 1961, pp. 23 y 30; y 120, 1961, p. 24.

35 Christopher Lasch, La cultura del narcisismo, Bompiani, Milán, 1981 y 1988 (1979); cfr. en particular el capítulo 4, «La banalidad de la falsa autoconciencia: teatralidad de la política y de la existencia cotidiana», pp. 86-114, y los párrafos dedicados a "La política como espectáculo», pp. 92-96, y a «El culto a los héroes y la idealización narcisista», pp. 99-101 (trad., con título homónimo, de Jaime Collyer, Andrés Bello, Barcelona, 1999). 
España es la democracia, debe ser la democracia, un bien al que tiende perpetuamente el mundo entero, pues «también España era una mina de azufre», como se lee en la novela-cuento de Sciascia. Significativa es, además, la frase con que Diego-Carlos, en la película de Resnais, liquida la aspiración de los jóvenes revolucionarios leninistas que quieren golpear a su país con explosivos plásticos: «el internacionalismo consiste, en primer lugar, en hacer la revolución en casa». Y es esto lo que, a su modo, hace el personaje sciasciano en la Italia fascista; lo que, a su modo, hace Diego-Carlos dejando Francia y volviendo a España para vivir la huelga general, un posible arresto o incluso la muerte.

El hecho de volver a Italia y a España no entraña realmente ninguna diferencia, más allá de la que se deduce de los distintos tiempos históricos en ambas narraciones. Pero, en sí mismo, prueba la común voluntad de dos «fichas» de sustraer la guerra civil espańola (y su herencia, la búsqueda de la democracia) a la pálida instrumentalización de los demás países, en definitiva menos honesta y coherente que la legendaria "charla» y la (casi) inmediata "medida" novelesca del conflicto espańol y del mundo en Hemingway. Entre la Italia fascista de la segunda mitad de los años treinta y la España todavía franquista de la primera mitad de los sesenta — que funcionan casi como "papel de tornasol» respecto a la Italia en que escribe Sciascia y la Francia en que rueda Resnais - podemos acaso buscar y leer una respuesta tardía, nada fácil, al imperialismo y la Realpolitik; una suerte de bumerán que aspira a hacer que Espańa sea respetada en cuanto tal, fuera y dentro de sus fronteras, más allá de las instrumentalizaciones nacidas de aquella política, cuyo iter tal vez merece la pena sintetizar con las palabras de Hans Magnus Enzensberger, tomadas de sus Perspectivas de guerra civil (1993):

En la Edad del imperialismo, cualquier conflicto interno asumía desde el principio una dimensión internacional. La llamada Realpolitik se las arreglaba para que toda guerra civil fuese fomentada e instrumentalizada por parte de potencias extranjeras. Las facciones enfrentadas funcionaban así como fichas de un juego mucho más vasto. Lo que interesaba a las grandes potencias era expandir sus áreas de influencia, así como sus imperios coloniales. Baste recordar las distintas intervenciones europeas y norteamericanas en China, o las que siguieron al putsch de Octubre de los bolcheviques, o la guerra civil española, que ha sido interpretada justamente como un ensayo general de la segunda guerra mundial. ${ }^{36}$

36 Hans Magnus Enzensberger, Prospettive sulla guerra civile, Einaudi, Turín, 1994 (1993), p. 8. (Perspectivas de guerra civil, trad. Michael Faber Kaiser, Anagrama, Barcelona, 1994). 
Desde la perspectiva de Enzensberger, todas las guerras civiles de la edad del imperialismo y su "lógica expansionista» —a la que "las superpotencias se atuvieron [...] todavía en los ańos setenta»— ${ }^{37}$ son guerras mundiales. (Y en tal sentido, tampoco tiene razón de ser aquella polémica cantinela que pretende presentar el conflicto español —apoyándose incluso en datos documentales como "el plan de Negrín y Del Vayo de hacer confluir la Guerra de España con la guerra mundial»— como un conflicto mundial a todos los efectos, ${ }^{38}$ perdiendo prácticamente su especificidad, que en cambio adquiere, con toda su importancia, en la visión general de Enzensberger.)

Por lo demás, y a pesar de todo, en tiempos de la guerra civil española, el mundo permanece como un telón de fondo: la lejana América, el sueño de Ventura, bello sueño que de todos modos es también pesadilla («Sacco y Vanzetti»), y además y sobre todo Europa, «aquel jardín tan sereno [...] que nos esperaba para las vacaciones del 39» — podríamos recordar una vez más con Merleau-Ponty, C’è stata la guerra (Ha habido una guerra) (1945). ${ }^{39}$

En fin, lo que a menudo aflora en primer plano, en los años del conflicto español y su inmediato entorno temporal, y también más allá de la supuesta y mal entendida influencia de Hemingway, es la imagen míticofolclórica de un país solo, aislado, fuera del tiempo, al que todos van a combatir casi como a un coliseo, un estadio lleno de pueblos diferentes, una especie de coso europeo montado —en una suerte de exposiciónpara una guerra-corrida-espectáculo; aquella que Leonardo Sciascia asocia en El antimonio, polémica y no casualmente, al «entusiasmo» del «secretario fascista», "fan del general Bergonzoli», "como si Bergonzoli fuese un jugador de fútbol o un torero». ${ }^{40}$

Tal coso — donde toda Europa parece mimar verdaderamente la coreografía trágica de un torero-y sus demás variantes, por ejemplo «el

37 Ib. Y quizá todavía en nuestros días. Piénsese en la guerra de Iraq, que no es del todo comprensible desde una perspectiva posimperialista.

38 Cfr. al menos, parcialmente, Léo Palacio, 1936: La Maldonne Espagnole. Ou la guerre d'Espagne comme répétition générale du deuxième conflit mondial, Privat, Toulouse, 1986. Pero cfr. además Gabriele Ranzato, L’eclissi della democrazia, cit., p. 643 (también la p. 627).

39 Merleau-Ponty, C’è stata la guerra, cit., pp. 169-171.

40 Sciascia, L'antimonio, cit., pp. 228-229. 
establo», no solo se registran en el vitalista y «español» Ernest Hemingway, que en cualquier caso abre camino, sino, sobre todo, en un menos conocido John Dos Passos, según la reciente relectura de Pascal Dethurens a propósito del fin del mito europeo y la guerra civil española, en su De l'Europe en littérature (1918-1939) (2000)..$^{41}$

Manhattan Transfer (1924) es la novela del fin del mito europeo. Una década más tarde, el corral cede el lugar, en Dos Passos, al matadero de Europa, y el hortus conclusus a la arena sangrienta. Momento en que, desesperando del giro que tomaban los acontecimientos en ese antiguo mundo, e indignado al ver humilladas las ideas democráticas durante la Guerra de Espańa, redacta un breve panfleto, en julio de 1937, en el que, «renunciando a los estrechos lazos que [le] unían a Europa, le volvió la espalda de una vez por todas» [...] Su última novela antes de la Segunda Guerra Mundial, Aventuras de un joven (1939), proviene de esta ruptura, y su protagonista, Glenn Spotswood, sustituye la corrida [...] o el matadero por el establo. Mediante una asociación de imágenes, que supone una inconsciente inmersión en el mito, Glenn percibe casi simultáneamente «manadas de bueyes» avanzando por las carreteras de España $y$, por esas mismas carreteras, "el rugido y el chirriar de un desfile de tanques».

Hemingway, seguramente, había abierto la vía (imaginaria) a este "desplazamiento». Dos Passos le felicita incluso, en una carta de febrero de 1932, por su novela Muerte en la tarde [...] Sigue escribiendo, en ese sentido, reviviendo la imagen de la corrida y la sangrienta carnicería, al crítico literario norteamericano Edmund Wilson, en marzo de 1937, que el «espectáculo de Europa» («the European show») se resume por completo en "el vasto matadero de la guerra civil española». Establece, por último, en sus Journeys Between Wars, en 1938, un vínculo indefectible entre Europa y la corrida, equiparando, al parecer, ambos «espectáculos», ya que Europa a menudo, presa del pánico, mima la coreografía trágica de un torero. «En lugar de corridas, los carteles [de Valencia] anuncian la guerra civil [...]. En ellos hay franceses, belgas, alemanes, polacos, yugoslavos, italianos».

Y un poco como show, por desgracia, como espectáculo apocalíptico de fin del mundo, el de la vieja Europa precisamente, y como variante o casi como origen trágico de los muchos conflictos (no) mundiales - e irresueltos- del siglo XX, la guerra civil española vuelve poco a poco a ocupar los estantes de las librerías y a gritar, como el Madrid de Leonardo Sciascia, su pertenencia a una "alucinación» colectiva y siempre actual. ${ }^{42}$

41 Pascal Dethurens, De l'Europe en littérature (1918-1939), Droz, Ginebra, 2002, p. 273-275.

42 Actualidad incluso, como veremos, de guerra de mundos, de pueblos, de imperios, en la que una suerte de wellsiana war of the worlds toma del pasado y proyecta en el futuro las guerras románticas del siglo XIX por las distintas independencias nacionales y todos aquellos conflictos, más antiguos, en que un esclavo soñó con la libertad. 
Quizá también porque el conflicto español «fue la primera guerra documentada - "cubierta” - en sentido moderno por un cuerpo de fotógrafos profesionales enviados a primera línea y a las ciudades bombardeadas, cuyas fotos fueron inmediatamente publicadas en periódicos y revistas, ya fuera en España o en el extranjero». Lo recuerda todavía recientemente Susan Sontag, Ante el dolor de los demás (2002). ${ }^{43}$

Frente a la más reciente vuelta a la guerra civil española, frente al dolor de una actualidad voceada y acaso manipulada, ${ }^{44}$ desbordante a veces y no siempre convincente, por lo menos a nivel literario, leer aunque solo sea un fragmento extractado de El antimonio sciasciano, como el de las mariposas de Madrid, puede ser verdaderamente una ocasión para sintonizar con un momento histórico difícil de seguir por su cambiante, metamórfico reaflorar. Difícil de seguir sobre todo en ciertas versiones narrativas actuales, como las que ofrece el polar o biografías noveladas más o menos atendibles.

Durante la última década, dentro del importante binomio literatura e historia ${ }^{45}$ pero haciendo numerosas concesiones al mercado editorial, a los géneros y temas que más parecen sostenerlo — la novela, la guerra-, tales versiones han tratado de reapropiarse, en cualquier caso, de un problema sin resolver en nuestro imaginario cultural. Han intentado representarlo, llevarlo a escena, siguiendo evoluciones distintas, a veces incluso perniciosas, hijas de aquellas instancias narratológicas que se abren a los seductores caminos de la fiction (y de la docufiction), origen de una serie de relatos cuyo único objetivo es «dejarse leer». ${ }^{46}$

43 Susan Sontag, Davanti al dolore degli altri (2002), Mondadori, Milán, 2003, p. 17 (Ante el dolor de los demás, trad. Aurelio Major, Alfaguara, Madrid, 2003).

44 Susan Sontag sugiere incluso que la famosa foto de Robert Capa del miliciano republicano (Federico Borrell García) caído durante la guerra civil española, puede ser fruto de alguna manipulación. Cfr., sin embargo, Laurent Gervereau, Montrer la guerre? Information ou propagande, Isthme, París, 2006.

45 Cfr. Lidia De Federicis, Letteratura e storia, Laterza, Roma-Bari, 1998.

46 Aunque cfr. Giuseppe Ricuperati, Apologia di un mestiere difficile. Problemi, insegnamenti e responsabilità della storia, Laterza, Roma-Bari, 2005. Permítaseme remitir asimismo a Luciano Curreri, «La sfida di non farsi leggere. Appunti intorno a Tristano muore (2004) di Tabucchi e Alla cieca (2005) di Magris», en Angela Barwig y Thomas Stauder (eds.), Intellettuali italiani del secondo Novecento, Verlag für Deutsch-Italienische Studien, Oldenbourg, 2007, pp. 176-195. 
Pero antes que esos relatos hay otros, de los años de la guerra en adelante, que se originaron, sobre todo, en aquel entresijo de fascinación, miedo, muerte y renacimiento en virtud del cual, al lado de Sciascia y Madrid, me ha parecido que podía reunir, presentar y discutir algunos narradores italianos (y extranjeros) que se interesaron por la guerra civil española, como mariposas de Madrid, dentro de una panorámica que de todos modos intentará entrecruzar, con mayor o menor rapidez y espíritu provocatorio, el pasado con el presente, la historia, historia literaria, con la actualidad, la crónica.

Madrid «existía». Madrid existe. (Y se ha visto hace poco, en días de luto y angustia por la matanza de 2004, desgraciadamente recorrido por «una carrera por explotar los cadáveres con fines partidistas»). ${ }^{47}$ Para Leonardo Sciascia y para todos nosotros, la capital del conflicto y del país existe todavía, y lo mismo todas las ciudades españolas agredidas, bombardeadas, heridas durante la guerra civil; también aquellas que los narradores italianos no evocaron o representaron.

El asedio a Madrid, al que alude el sciasciano «dar vueltas» y al que ya se refería la "Breve crónica del régimen" de Las parroquias de Regalpetra $^{48}$ es ya, con la guerra en curso, el asedio a España. Combatir en Madrid, por los republicanos y por los voluntarios de las Brigadas Internacionales ${ }^{49}$ viene a ser como combatir en todas las ciudades españolas amenazadas, heridas: Madrid se convierte así, por un efecto amplificador, diseminante, en Guernica, Bilbao, Santander, San Sebastián, Barcelona, Teruel, Valencia...

47 Riccardo Chiaberge, «Spender e l'indignazione selettiva», Domenica, suplemento del periódico Il Sole-24 Ore, 80, 2004, p. 29.

48 Sciascia, "Breve cronaca del regime», en Le parrochie di Regalpetra, col. Libri del Tempo, Laterza, Bari, 1956 (Las parroquias de Regalpetra; Muerte del inquisidor, trad. Rossend Arqués, Anagrama, Barcelona, 1990), y ahora al comienzo de Opere. 1956-1971, cit., p. 43: «Bilbao, Málaga, Valencia; y luego Madrid, Madrid sitiada». Pero sobre "Breve crónica del régimen» volveremos hacia el final del segundo epígrafe de este capítulo.

49 Cfr. al menos, a este propósito, Rémi Skoutelsky, L'Espoir guidait leur pas: les volontaires français dans les Brigades internationales 1936-1939, Grasset, París, 1998; y Giulia Canali, L'antifascismo italiano e la guerra civile spagnola, Manni, San Cesario di Lecce, 2004; concretamente, el segundo capítulo, «Intervención del partido comunista, del partido socialista y del partido republicano: el batallón Garibaldi y las Brigadas Internacionales», pp. 39-77. 
Es más, la resistencia madrileña se convierte en símbolo de toda la resistencia urbana (y no urbana) en la guerra antifascista y antinazi que se prolongará después de 1939 más allá de las fronteras españolas, por lo que Madrid (un nuevo Madrid) será «Milán para Vittorini» o «Stalingrado para Neruda» (e incluso, con una cierta distancia irónica, «un recodo del río Tagliamento" para Bartolini). ${ }^{50}$ Mientras que, por parte de los rebeldes franquistas y de los nazi-fascistas, "Madridgrado” es el nombre que daban a la ciudad ańorada y odiada aquellos que la asediaban" y "es también el título de una célebre novela de Francisco Camba»: «encontramos aquí la confirmación de su excepcional importancia entre las obsesiones de los rebeldes». ${ }^{51}$

Madrid, Milán, Stalingrado. Pero también Sciascia, Vittorini, Neruda. Tres escritores, pero a la vez tres hombres, tres mariposas. ${ }^{52}$ Madrid-

50 La Milán de Vittorini y la Stalingrado de Neruda son recordadas en tal sentido por Aldo Garosci, "Gli intellettuali italiani e la guerra di Spagna», en Gli intellettuali e la guerra di Spagna, Einaudi, Turín, 1959, pp. 454-455 (Los intelectuales y la guerra civil de España, Júcar, Gijón, 1981). Claro que, aun en sus distintas metamorfosis, Milán conserva también una identidad propia, una presencia autónoma como ciudad herida, de la que es testigo, por ejemplo, Fortini en Guerra a Milano, de 1943, que abre luego, en 1963, Sere in Valdossola, para lo cual cfr. Franco Fortini, Sere in Valdossola, Marsilio, Venecia, 1985 (con una "Advertencia» en pp. 3-5, y el pról. de 1963 en pp. 7-15), pp. 19-157; léanse, por ejemplo, las pp. 75-78, donde Milán es, en cualquier caso, paragonada, al comienzo del bombardeo, con la generación de la ARMIR (Armata Italiana in Russia) y la ciudad rusa de Gómel, lugar de durísimos enfrentamientos durante la segunda guerra mundial: «Esta vez entro en el refugio. Hombres apretados a mi alrededor. A un sargento le castañetean los dientes y balbucea: "Como en Gómel, como en Gómel...”"(p. 75). Pero, más allá del cuadro urbano, cfr. Elio Bartolini, Il Ghebo (1946), La Nuova Base, Udine, 1970, y ahora, con introd. de Raffaele Crovi, en Avagliano, Roma, 2006, pp. 48-49: "pero arriba, en el puesto de mando, habían decidido hacer de aquellas montańas y de aquel recodo del Tagliamento un nuevo Madrid; la Pasionaria decía eso precisamente: "un nuevo Madrid" [...]. Y desde la línea en que se habían apostado (la primera, porque debían llegar a una segunda, y luego a una tercera, así hasta el "nuevo Madrid") veían arder en la noche los pueblos de los valles».

51 José Carlos Mainer, «Madridgrad ou le regard des autres», en Carlos Serrano (ed.), Madrid 1936-1939. Un peuple en rèsistance ou l'épopée ambiguë, Autrement, París, 1991, pp. 115-116. En el mismo volumen cfr. Émile Temine, «Le mythe et la réalité», pp. 20-30; del mismo cfr. además «Du réel au légendaire», en La Guerre d'Espagne, un événement traumatique, Complexe, Bruselas, 1996, que de nuevo ofrece una reflexión sobre interpretaciones y representaciones de la guerra civil espańola.

52 Viene a la mente incluso Hemingway, pero esta vez por un relato y un tono que no se corresponden demasiado con las mariposas sciascianas. Pienso en The Butterfly and the Tank (1938), "La farfalla e il carro armato", en Vincenzo Mantovani (ed.), Storie della 
llama, Madrid sueño encendido, incendiado: imágenes que valen no solo para la ciudad en sí, sino también y sobre todo para los hombres, para todos los hombres que, fundiéndose casi a la misma ciudad herida, sacrificaron su existencia a esa llama, a ese sueño encendido y dilatado, convirtiéndose en parte integrante, fuera o dentro de sus confines, de su historia, de su existencia, de su devenir. En la película de Frédéric Rossif Morir en Madrid (1963), y en otros manifiestos de aquel cinéma-vérité dedicado a la guerra civil de España y a la lucha por la libertad, la cámara se detiene en los hombres que se matan en las afueras y en el cogollo de Madrid.

Una voz fuera de campo informa toda la batalla, la nombra (entre el audiovisual y la escritura $)^{53}$ y nos la entrega; hasta tal punto que un joven narrador italiano parece haberla retomado recientemente, para seguir a los últimos "rebeldes", a los "perdedores, que no vencidos", ${ }^{54}$ desde las "afueras» de la ciudad —aquel "perímetro» sobre el que «espontáneamente» se dispone «la población de Madrid» para «rechazar los primeros embates de los falangistas»- a los confines de España, hacia el exilio (el primero de todos el francés, del que hablábamos hace poco).

Y desde aquellos confines y afueras se llega siempre y de todos modos al cogollo de una ciudad en la que la guerra civil es historia "abierta» y «doble», complicada por tramas internas: fascistas y antifascistas, anarquistas y comunistas estalinistas y/o comunistas por naturaleza y comunistas convertidos; o bien, en sede literaria, un escritor como Ignazio Silone y el escritor comunista "tipo" de 1930, que siente por obreros y campesinos el mismo tipo de pasión que Marcel Proust por sus duquesas.

guerra di Spagna. La quinta colonna, Mondadori, Milán, 1972 (reed. col. Oscar, 1975, p. 81): "Escuche", dijo el director. "Qué raro. La alegría de este hombre choca con la seriedad de la guerra como una mariposa...". "Oh, precisamente como una mariposa", dije yo. "Demasiado". "No bromeo en absoluto", dijo el director. "¿Lo ve? Como una mariposa y un tanque" (La mariposa y el tanque, trad. Félix della Paolera, Bruguera, Barcelona, 1981).

53 Cfr. Frédéric Rossif, Madeleine Chapsal, Mourir à Madrid, una película de Rossif con guión de Chapsal, Seghers, París, 1963 (reed. Gérard et C., col. Bibliothèque Marabout Université, Verviers, 1964, pp. 48-62). Cfr. el reciente DVD editado por Éditions Montparnasse, París, 2006.

54 Cfr. Pino Cacucci, Tina, Interno Giallo, Milán, 1991 (reed. Tea, Milán, 1995 y 2001, p. 145) (Tina Modotti, trad. Mercedes Corral, Circe, Barcelona, 1992); y también de Cacucci, ;Rebeldes!, col. Serie Bianca, Feltrinelli, Milán, 2001 (reed. col. Universale Economica Feltrinelli, 2003, p. 10). 
Lo ha sugerido, antes de las (más o menos) recientes acusaciones que han caído sobre Silone y antes de la libreta de las calificaciones de Lord Ralf,55 un opositor al fascismo y al comunismo, contrario a las "polarizaciones arbitrarias», al "eterno dualismo», ${ }^{56}$ como Arthur Koestler, poco dado al sueño romántico que vivieron algunos escritores de los años treinta, en particular durante la guerra civil española, y ocupado en escribir — desde Diálogo con la muerte: un testamento español (1937) a Autobiografía, I. Flecha en azul (1952), pasando por las vicisitudes narradas en Escoria de la tierra (1941) - una autobiografía sincera hasta el punto de hacer que parezcan pura hipocresía las Confesiones de Rousseau y la Vida de Cellini. ${ }^{57}$

Pero también es cierto que su autobiografía, que en cierto modo arranca con Diálogo con la muerte: un testamento español, "un libro de actualidad sobre España», como él mismo lo define, se superpone a la novela Los gladiadores, que, empezada en 1935, no ve la luz hasta 1939, último año de la guerra, tras "una especie de carrera de obstáculos» ${ }^{58}$ de la que nos habla Koestler en 1965. Considerada en su totalidad, entre la desilusión por el partido comunista y la Rusia estalinista y la dramática conciencia del poder nazifascista embistiendo media Europa, la tragedia política e ideológica del siglo XX queda velada (sin perderse) en una pasado aventurero, lejano, en otra guerra civil y servil, ${ }^{59}$ en "otra revolución abortada», espejo de la rusa, sobre todo, y de otras que, en parte, se inspiraron en ella. Ese pasado ofrece idealmente a Arthur Koestler «una sensación de paz y de alivio", además de "una evidente analogía entre [su] tiempo y aquella lejana época». ${ }^{60}$

55 Pienso en Dario Biocca, Ignazio Silone. La doppia vita di un italiano, Rizzoli, Milán, 2005, y en Ralf Dahrendorf, Versuchungen der Unfreiheit, C. H. Beck, Múnich, 2006, que condena a Arthur Koestler; pero cfr. Giuseppe Bedeschi, «Le pagelle di Lord Ralf", Domenica, suplemento del periódico Il Sole-24 Ore, 144, 2006, p. 27.

56 Cfr. Gianni Sofri, introd. a Arthur Koestler, Schiuma della terra, apéndice Leo Valiani, Il Mulino, Bolonia, 1989 (1941), p. XVI. (La escoria de la tierra, trad. Román Jiménez, Editorial Sudamericana, Buenos Aires, 1943).

57 Ib., p. XXI. Sobre la siguiente y divertida presentación que Koestler da de sus páginas autobiográficas, véase el tercer capítulo de la primera parte de Autobiografía, I. Flecha en azul (1952).

58 Arthur Koestler, «Poscritto all'edizione danubiana», en I gladiatori, Net, Milán, 2002 (1939), p. 314 (Los gladiadores, trad. María Eugenia Ciocchini, Edhasa, Barcelona, 2005).

59 Ib., pp. 114-119.

60 Ib., pp. 313-314. 
En nuestros días, la escritura de Pino Cacucci, brevemente evocada, parece buscar la guerra civil espańola con el propósito de no ceder, al menos en el fondo, a un pasado aventurero, lejano y novelesco, pero, entre Tina (1991) y Ribelli! (¡Rebeldes!) (2001), hace más de una concesión a lo que algunos escritores (y quizá muchos lectores) en Italia consideran a estas alturas un pasado realmente lejano, aventurero y novelesco sin más, donde encontrar paz y relax a buen precio sin ninguna analogía evidente con sus vidas. La novela de formación se asemeja a un póster.

Salvadas, pues, las debidas distancias - Cacucci y Koestler son comparables en la superficie y en cuanto a provocación, y no solo porque el segundo nace medio siglo antes y vive y escribe en directo durante aquellos años españoles trágicos-, una cierta apropiación narrativa de la guerra civil parece producirse, en ambos casos, mediante casi el mismo mecanismo psicológico: queriendo enunciarla en términos autobiográficos o biográficos, por un acuerdo moral consigo mismos, volvemos a hallarla también como pasado aventurero en fondos y entornos narrativos, ensanchados por su simbolismo a todos los niveles. Cierto que aquel pasado aventurero es decididamente menos problemático para el joven escritor italiano, a veces en busca de un fácil aplauso adolescente, con los malos y los buenos desfilando por la página-pizarra.

Dicho esto, el pasado-presente de Pino Cacucci nos puede en cualquier caso ayudar a periodizar y proponer una nueva cronología para la narrativa italiana que trata de la guerra civil española. ${ }^{61} \mathrm{Y}$ el pasado-pasado de Arthur Koestler puede hacer más interesante nuestro itinerario, aun cuando los ańos 1936-1939 después de Cristo se deslicen al 73-71 antes de Cristo, para luego remontarse al siglo XX, a los procesos estalinistas de Buio a mezzogiorno (Oscuridad a mediodía) (1940), que con Los gladiadores (1939) y Arrivo e partenza (Llegada y salida) (1943) forma una trilogía "cuyo hilo conductor es un problema crucial para la ética revolucionaria y la ética política en general: hasta qué punto el fin justifica los medios. Una cuestión tan vieja como el mundo». ${ }^{62}$

Desde esta perspectiva, el siglo I a. C. se nos presenta como un contenedor más capaz de lo que el mismo Koestler, retrospectivamente, sugie-

61 Para lo cual léase el capítulo tercero de este libro.

62 Arthur Koestler, «Poscritto all’edizione danubiana», cit., p. 313. 
re; o bien como un pasado donde realmente aparecen superpuestos un apólogo sobre la heterogénesis de los fines, un apólogo sobre la libertad, que no tiene edad, y una narración histórica, que sí la tiene, deslizando así lo aparentemente inactual sobre lo actual. De ese modo la tradición, que la modernidad está siempre a punto de barrer, es elevada a símbolo de esa misma modernidad y de su loada afinidad con la muerte, con la deconstrucción del mundo y de los hombres. El sueño de libertad de los gladiadores, de Espartaco ofrecido a la derrota, es, como el de los republicanos españoles, una prolongación de la hermandad con la muerte - y su consiguiente rechazo de la pesadilla que devora tan noble sueńo- que anima Diálogo con la muerte: un testamento español, conocido en italiano como Dialogo con la morte, título de la segunda parte del libro de 1937, que luego Bompiani publicó como texto independiente en $1947 .{ }^{63} \mathrm{Y}$

63 Arthur Koestler, Spanish Testament, introd. duquesa de Atholl, Gollancz, Londres, 1937 (Diálogo con la muerte: un testamento español, trad. José Erezuma, Amaranto Editores, Pozuelo de Alarcón, 2004), cuya parte I, pp. 15-204, consta de nueve capítulos que dan cuenta de la actividad periodística de Koestler en Espańa, como corresponsal del News Chronicle, hasta su arresto y condena a muerte por los nacionales tras la toma de Málaga en febrero de 1937 («Viaje al cuartel general de los rebeldes», «Retrospectiva histórica», «La ruptura», "El trasfondo», "La Iglesia militante», «Propaganda», "Los héroes del Alcázar», «Madrid», "Los últimos días de Málaga»), mientras que la parte II, pp. 205-384, titulada «Diálogo con la muerte», presenta un texto único, si bien dividido en capítulos, de corte autobiográfico y más propiamente literario, narrativo, dedicado a su experiencia de la cárcel en espera de ejecución, a la que Koestler escapa. La edición italiana, Dialogo con la morte, col. Vinti e Vincitori, Bompiani, Milán, 1947, al cuidado de Camillo Pellizzi, que reproduce solo el título de la parte II: «Dialogue with Death», sin otras indicaciones, deriva muy probablemente de la edición norteamericana, que presenta solo la 2. a parte de Spanish Testament dentro de una traducción pero sin precisar edición (o texto) de referencia; cfr. Arthur Koestler, Dialogue with Death, trad. Trevor y Phyllis Blewitt, Macmillan, Nueva York, 1942. Lo deducimos también a partir de un epílogo diferente, más breve —referido a «una batalla aérea sobre Teruel en la primavera de 1938»—, que la edición norteamericana presenta en la p. 215 y que corresponde al de la edición italiana en su p. 271. Y esto quizá no sea todo. En el epílogo desaparece también el nombre de Franco y los supervivientes "continúan ahora sus diálogos con la muerte en medio del apocalipsis europeo" (p. 271). La intención privada y literaria — ya manifiesta en el prólogo («Morir — también al servicio de una causa impersonal - es siempre un asunto personal e íntimo», p. 5) — es la de hacer aparecer el texto como un diario y una novela sobre la muerte, alejándola un poco del reportaje y también, en cierto sentido, de la experiencia española más cronística; pero quizá subyace también una intención pública, editorial e incluso política, debida al nuevo itinerario emprendido por la España neutral de Franco durante la Segunda Guerra Mundial — de la que firma solo "el preludio" (p. 271)—, tendente a eludir o dar implícitamente, por ejemplo, hechos como el de la División Azul en Rusia, para la cual cfr. el reciente Xavier Moreno Juliá, La División Azul. Sangre española en Rusia 1941-1945, Crítica, 
aquellas tierras tan ligadas a la historia de España (y de Italia), la Campania, el sur (el sur de Europa), nuevos coliseos repletos de distintos pueblos en combate, acogen tal prolongación literaria y civil de manera ejemplar, al menos para algunas de sus finalidades implícitas, sobreentendidas.

En este sentido hay que releer las declaraciones koestlerianas arriba citadas, relativas a la decepción ante un "Dios que ha fracasado»; $;^{64}$ ante aquella utopía soviética que fascina y ciega un tanto, además de a Koestler, a toda una generación de intelectuales, desde Auden a Malraux, y que en los estalinistas años treinta les convierte en espejos de «un drama objetivo más grande que ellos». Aquella utopía soviética que responde, sobre un "equívoco de fondo», "a una exigencia de salvación y a una necesidad de utopía de tipo existencial»: "una exigencia abstractamente intelectual que encuentra su crisol ético e ideal en la Guerra de España ${ }^{65}$ —antes de las derivas religiosas y metafísicas de Auden, por ejemplo.

Antes de tales derivas y de otras mixtificaciones más ingenuas —incluso sinceras y más o menos actuales-, parece que el objetivo de Los gladiadores fuese también llegar a mezclar una novela moderna, como La esperanza (1937) de Malraux —escrito que «filma» los trágicos sucesos españoles antes incluso de su versión cinematográfica y que se abre precisamente en Madrid_-, con la tradición de la novela peplum más mesiánica y apocalíptica, catártica y espiritual, con la antigüedad recuperada en el presente no solo para satisfacer los escrúpulos del conservador de arte, del historiador o del erudito.

Barcelona, 2004. He precisado en nota estos datos porque, además, la edición italiana que continúa circulando es la arriba citada, propuesta de nuevo por Il Mulino de Bolonia en 1993, con trad. de Camillo Pellizzi revisada por Pietro Petrignani, y porque a menudo, en nuestra tradición editorial y crítica (aunque también en la francesa, por ejemplo), se confunden o identifican Spanish Testament y Dialogue with Death.

64 Conocido libro con diversas voces testimoniales, The God that Failed (1949 y 1950), ed. en italiano por Comunità, Milán, 1950; es el texto del que parte Chiaberge, Spender e l'indignazione selettiva, cit.

65 Vito Amoruso, introd. a Christopher Caudwell, Soggettivismo e realismo. Saggio sulla letteratura borghese in Inghilterra, De Donato, Bari, 1971 (1970), pp. 9-11. Christopher Caudwell (seudónimo de Christopher St. John Sprigg), nacido en 1907, de la generación de Auden, uno de los mayores críticos marxistas de la primera mitad del siglo XX, murió en 1937 durante la defensa de Madrid. Romance and Realism, inédito hasta 1970, fue escrito en plena década de los treinta, entre el avance del nazi-fascismo en Europa y la guerra civil española, y traza, de Shakespeare a Hemingway, de los Elisabetianos a Spender, una cuadro de la cultura literaria burguesa tendida no por casualidad entre dos polos, cuales son el subjetivismo y el realismo. 
Y si la guerra civil española de un aviador como André Malraux hace pensar en seguida en el cine o en quien, más recientemente, del cine pasa a la novela, como Carlos Saura con iEsa luz! (2000), ${ }^{66}$ quizá la novela peplum decimonónica, evocada en clave "socialista» por Arthur Koestler en Los gladiadores, puede inducirnos a recordar, con el Spartaco de Raffaello Giovagnoli, ilusiones y desilusiones del periodo posterior al Risorgimento.* Esta novela histórica de un narrador y patriota olvidado del siglo XIX, rebelde, comprometido, presenta un texto rico de «aventuras» e impulsos libertarios, destinado a hacer fortuna en los países socialistas. Fue publicada en 1874 y escrita en los años en que Italia pagaba muy caro, con muchas "pequeńas» guerras civiles y de siervos, la búsqueda de su unidad política y territorial. ${ }^{67}$

66 Cfr. Carlos Saura, Quella luce, Einaudi, Turín, 2002 (Esa luz: guión cinematográfico, ed. Agustín Sánchez Vidal, Instituto de Estudios Altoaragoneses, Huesca, 1995).

* N. de los T.: Periodo de la historia de Italia comprendido entre comienzos del siglo XIX y 1870, durante el cual consiguió su unificación.

67 Cfr. Raffaello Giovagnoli, Spartaco, col. La Giraffa, Parenti, Florencia, 1955. Para los antecedentes italianos y su fortuna, desde Garibaldi hasta Gramsci, así como para lo más inmediatamente relacionado, decimonónico e italiano, léase Fabio Danelon, "La narrativa dell'Ottocento. La caduta degli dèi», en Pietro Gibellini y Raffaella Bertazzoli (eds.), Il mito nella letteratura italiana. III. Dal Neoclassicismo al Decadentismo, Morcelliana, Brescia, 2003, pp. 381-383. Sería útil seguir de cerca la fortuna del Spartaco de Giovagnoli y verificar su posible incidencia durante el siglo XX en otras obras narrativas dedicadas a la revuelta de los esclavos del 73-71 a. C., pasando revista a los diferentes contextos históricos en los que tal revuelta acaba reactivándose, dotada de nuevo significado, desde el difícil periodo posunitario italiano a las experiencias traumáticas de la guerra civil espańola, y desde Stalin y las "purgas» al general Mac Arthur que invade Corea del Sur, a caballo todavía, por ejemplo, de Los gladiadores (1939) de Koestler y Spartacus (1953) de Howard Fast. De esta última partió Stanley Kubrick para su conocida película de 1960. Cfr. a este propósito el discurso de Laura y Luisa Cotta Ramosino, Cristiano Dognini, Tutto quello che sappiamo su Roma l'abbiamo imparato a Hollywood, Bruno Mondadori, Milán, 2004, pp. 27-35 y 183-184. Pero véanse también, al menos, Pier Paolo Fornaro, Trapassato presente. L'appropriazione psicologica dell'antico attraverso la narrativa moderna, Tirrenia Stampatori, Turín, 1989, pp. 93-94, 182-185. Sobre Koestler, del mismo Fornaro, «Impiccato da Weimar», Alias, 30, 2001, p. 11; y sobre Fast, Massimo Raffaelli, «Un cult U. S. A. sulla guerra servile», en el mismo suplemento semanal del periódico Il Manifesto, un rico monográfico dedicado a "Roma antica, una crisi moderna». Además, la fortuna del Spartaco de Giovagnoli no se limita a contextos histórico-literarios, sino que también puede rastrearse en contextos histórico-deportivos: es el caso del Spartak de Moscú, equipo formado en el barrio obrero de Presnja, que debuta a comienzos de los años veinte con el nombre del gladiador rebelde que jugadores e hinchas habían conocido gracias a la novela de Giovagnoli. Cfr. Mario Alessandro Curletto, Spartak Mosca: storie di calcio e potere nell'URSS di Stalin, Il Melangolo, Génova, 2005. 
Precisamente porque, como elemento narrativo (y no solo), la guerra civil española es un acontecimiento «abierto», una guerra no del todo acabada — quizá porque «quien vence decide cuándo ha acabado la guerra»— ${ }^{68} \mathrm{o}$ un conflicto que se dilata objetivamente en el tiempo a través de otras luchas, pasadas o futuras, no está de más decir algunas palabras a propósito de Leonardo Sciascia y El antimonio, que como relato tal vez inacabado se ubica - conviene repetirlo- en la segunda edición de Los tíos de Sicilia, publicada también por Einaudi, en 1960, pero en la colección Coralli (la primera, dentro de la colección Gettoni, es de 1958).

Los tíos de Sicilia son, como sugiere Ambroise, una colección ejemplar de "composiciones de historia e invención». ${ }^{69}$ Para entendernos: en El antimonio tenemos la historia de un minero siciliano - uno de tantos pobres italianos del sur, en los ańos treinta- que por hambre pero también y sobre todo por desesperación se marcha como voluntario a la Guerra de España, con los legionarios fascistas; la invención hace luego de esta historia un "texto clave de toda la obra sciasciana», incluso «una metáfora de la "vocación literaria"». ${ }^{70}$

Si aceptamos por un momento, sin olvidar los límites señalados en el capítulo primero, la intuición crítica de Ambroise, en un sentido más metaliterario que psicoanalítico, podremos tratar de enlazar una tradición narrativa y una vocación literaria anclada en el siglo XX —identificable con cierta dificultad, sin embargo, en relación con la guerra civil españolacon un conjunto todavía bastante débil pero significativo de novelas y relatos recientes que, de manera más o menos íntegra y explícita, hacen referencia a aquella guerra, a la que adecuan espacios y tiempos narrativos.

Replanteando, de acuerdo con Borges, la «tradición» como «obra del olvido y de la memoria» ${ }^{71}$ y partiendo de una tradición novelesca «en peli-

68 Cfr. Alessandro Baricco, Senza sangue, Rizzoli, Milán, 2002, p. 25 (Sin sangre, trad. Javier González, Anagrama, Barcelona, 2003).

69 Ambroise, Invito alla letteratura di Sciascia, cit., p. 96.

70 Ib., pp. 95 y 91. Empero téngase en cuenta lo ya observado, también de manera polémica, en el capítulo primero, especialmente en relación con ciertas derivaciones críticas de este discurso.

71 Jorge Luis Borges, "Storia del guerriero e della prigioniera», en L'Aleph, col. Universale, Feltrinelli, Milán, 1959 (1952), p. 47 («Historia del guerrero y la cautiva», El Aleph, 1949 y 1974). 
gro» — que casi es necesario proteger, junto con la tensión intelectual y la vocación literaria que la animan-, podremos llegar a un presente no historificado y nada fácil de abordar, también en relación con esos índices a la baja de tensión intelectual y vocación literaria —infravalorados, cuando no descuidados directamente, por escritores y críticos-, para movernos por un doble itinerario, que se entrecruza: «autobiografía de la nación»e «Italia literaria». ${ }^{72}$

Partiendo de una tradición casi perdida - o casi inexistente-, trataremos de reseñar un presente colmado de autores diferentes a los del pasado. Presente con el que comienza a ser necesario ajustar cuentas, fijando límites cronológicos, proponiendo pequeñas reseñas, hipótesis de reseña, y tratando de llegar tal vez a alguna conclusión, siquiera sea provisional, ${ }^{73}$ dentro de la historia de la literatura y de la crítica literaria.

Recordando quizá, de modo preliminar, que historiadores y críticos literarios no deberían hablar solamente de aquello que aman $-E l$ antimonio y su entorno más o menos inmediato, en mi caso- o de lo que quieren hacer encajar en el canon de un siglo; ese siglo XX que, más allá de su cronología, es todavía capaz de sorprendernos, por fortuna, «lleno» como está «de anacronismos, de tiempos que no vuelven» — también de contratiempos- y «de personajes actuales que, en la recepción cultural, nacen más tarde de cuando lo hicieron en realidad». ${ }^{74}$

72 Cfr. una vez más Onofri, Storia di Sciascia, cit., y Stefano Jossa, L'Italia letteraria, Il Mulino, Bolonia, 2006. Cfr. Andrea Cortellessa, «Italia, entità letteraria a geometria variabile», Alias, 24, 2006, p. 18.

73 Con algo de excusatio non petita anticipada, por lo que tiene de provisional a lo largo de nuestra "charla», y por lo que debería tener quizá toda "charla» que se precie, especialmente en sus frases finales, que pretenden concluir y abrir un diálogo al mismo tiempo. Pienso en Soldados de Salamina. A cuarenta páginas del final, en un paréntesis, leemos: «jamás se encuentra aquello que se busca, sino lo que la realidad nos proporciona» (Javier Cercas, Soldati di Salamina, Guanda, Parma, 2002 [2001], p. 165). Buscando la guerra civil en la narrativa italiana del siglo XX, nos tropezamos con una realidad que no se ha traducido simplemente en los textos ni en los temas perseguidos (las ciudades heridas, por ejemplo). Luego, más allá de un «buen sueńo» bachelardiano, nos hemos movido entre el pudor y la despejada grandeza de una mirada que afronta los horrores (desde Sciascia a Ramondino), para terminar en la superación más desenvuelta, fácil y, en ocasiones, estereotipada de tales coordenadas, intentando tener en la mente, como hace Cercas, que "la realidad siempre nos traiciona, lo mejor es no darle tiempo y traicionarla antes a ella» (ib., p. 171).

74 Cfr. Ezio Raimondi, «Un'isola nell’oceano della quotidianità. La critica letteraria del Novecento", en Bruno Germano, Mario Ricciardi y Achille Tartaro (eds.), Letteratura 
La literatura «de biblioteca», hasta ahora encarnada por Sciascia, que hemos defendido y acaso demasiado aprisa dejado a un lado, puede armonizarse con prácticas casi periodísticas, «de librería», «de quiosco»o, incluso, «de Internet». Prácticas textuales que traten de atravesar la actualidad literaria, pero también de discutirla dentro de «urgencias no actuales», trazando un «mapa» para navegantes donde lo actual y lo inactual encuentren una razón de ser aparte de la mercantil. Un mercado que impone y opone - sobre todo, paradójicamente, al hilo de aniversarios- la lógica comercial de las «actualizaciones» a contrapelo de la tradición intelectual, percibida a estas alturas solo como hábito o vicio académico.

Tratando de llegar al hoy, en cambio, volveremos a partir de una cuestión que la lógica de las actualizaciones — y de la moda - no debe ni puede hacernos olvidar. Me refiero a un par de preguntas, a las que trataremos de responder de manera quizá no exhaustiva pero sí problemática, y siempre conjugando pasado y presente, «actualizaciones» $\mathrm{y}$ «urgencias no actuales»: «zen qué textos narrativos italianos anteriores a Sciascia, y con qué modalidades, es evocada de modo significativo o relatada la Guerra de España?»; «zamplifican meramente una tradición existente —angloamericana, francesa, española - o más bien dan vida a un conjunto de tradiciones, perdidas o inexistentes, dentro de una tradición todavía por "inventar"?».

\section{Antes de Sciascia. ¿Tradiciones perdidas o inexistentes?}

Maurizio Serra, en un libro publicado por Il Mulino en 1990 y dedicado al «esteta armado», presenta la guerra civil espańola como «el último conflicto romántico del viejo continente», pero también como «una guerra moderna» que "no consiente cargas de Langemarck ni hazañas de Fiume». ${ }^{75}$ Lanza luego la hipótesis de que "para aquellos que trasladaban a España la experiencia madurada midiéndose con el fascismo o el nazismo,

e critica. Esperienza e forme del '900, actas del congreso en homenaje a Natalino Sapegno (Saint Vincent-Aosta, 30 de septiembre-3 de octubre de 1991), La Nuova Italia, Florencia, 1993, p. 174.

75 Maurizio Serra, "Verso la Spagna», en L'esteta armato. Il Poeta-Condottiero nell'Europa degli anni Trenta, Il Mulino, Bolonia, 1990, pp. 127 y 135. 
apartados del contacto con el público y con los jóvenes de Italia o de Alemania, la guerra no podía convertirse en un asunto lírico, un tributo a las bellas letras»: "quizá así puede explicarse por qué italianos y alemanes, estando en primera fila desde el comienzo hasta el final del conflicto, han "producido" menos obras u otro tipo de obras». ${ }^{76}$

¿Cuáles? Testimonios, diarios, ensayos, estudios, artículos. Todos aquellos textos, en fin, que pueden llegar a ser (también) obras literarias y narrativas solo en manos de escritores «a tiempo completo", incluidos los debutantes (aquí entraría el Koestler de Diálogo con la muerte: un testamento español, primera y segunda partes, a caballo entre la crónica y la novela)..$^{77}$

Pero escritores italianos y alemanes de este jaez son prácticamente ajenos a la guerra civil española, por varias razones. Mientras que son numerosos los políticos que optaron por el exilio —a menudo ya estaban en él-y sucesivamente intervinieron en España, ocasión propicia, como es sabido, para el activismo de los exiliados.

Por otro lado, sin necesidad de filtros literarios y más que todos los demás antifascistas, los exiliados parecen discurrir «de un estado de patética catástrofe a las sublimidades de la tragedia». La intuición de Stephen Spender — que a la fidelidad del recuerdo vivido, joven y, a su manera, «romántico» ${ }^{78}$ añade un "cruel» sentido común — traza una doble vía:

76 Ib., p. 130.

77 Sofri, introd. a Arthur Koestler, Schiuma della terra, cit., p. XII: «Finalmente, Koestler volvió a la zona en poder del gobierno para montar allí una agencia internacional de prensa. Pero, esta vez, las cosas fueron mal. La caída de Málaga lo puso en manos de los franquistas. Pasó más de tres meses en prisión y fue condenado a muerte. Le salvó una campaña internacional y la intervención decidida del gobierno británico. Al final lo intercambiaron por una rehén, la bella esposa de un aviador franquista. De vuelta a Inglaterra, libre, escribió Spanish Testament en el otońo del 37: el libro que representó su debut como narrador».

78 Rasgo que, tratándose de Spender, no hay que leer tautológicamente, pues, nacido en 1909, tenía solo —o ya, considerado el momento - veintisiete años cuando comienza la guerra civil española. En efecto, el recuerdo del joven Spender, anclado en una vivencia histórica problemática, va más allá de cierto fatalismo koestleriano, de ciertas derivas religiosas y metafísicas de Auden, fruto a fin de cuentas, en ambos casos, de una aceptación más o menos resignada y sustancial del statu quo. En Stephen Spender, «más ingenuamente engañado», "la experiencia de una revolución catártica y espiritual se reaviva al ponerse al lado de la contestación juvenil en Praga y en París». Cfr. una vez más Amoruso, introd. a Christopher Caudwell, Soggettivismo e realismo. Saggio sulla letteratura borghese in Inghilterra, cit., p. 11. 
por un lado «la zona de los combates [...] limitada» y «las voces del individuo humano no [...] sofocadas, como en 1939, por la vasta maquinaria militar y propagandística» $;^{79}$ por otro, el Congreso de los Escritores Antifascistas en el verano de 1937 entre Valencia y Madrid, que, «con todas sus cualidades, tenía un poco el aire de una fiestecita de niños mimados». ${ }^{80}$

Esta dicotomía atraviesa el siglo XX y llega hasta nuestros días, absorbida por el mercado y despachada en una novela «astuta» pero que «jse lee de un tirón!». ${ }^{81}$ Pensamos en Soldados de Salamina, tercera novela de un profesor de literatura española, Javier Cercas, publicada en 2001, que alcanzó la vigésimocuarta edición en octubre de 2002 y fue editada en italiano por Guanda en enero del mismo año. Por un lado, tenemos los destinos individuales que conforman el libro, a partir del del novelista, proyectado un poco como un dios inepto pero óptimo con su creación, en cuya génesis se mide con un escritor del pasado, uno de los fundadores de Falange, Rafael Sánchez Mazas, salvado — no se sabe por qué- por un soldado republicano hacia el final de la guerra; por otro, el mismo soldado republicano — nos sentimos, cuando menos, empujados a creerloque se molesta, casi haciendo autocrítica, con los romanticismos de Hemingway y el programado carácter literario de la operación.

«¿La literatura? Antes la vida». Parecería como si la «fiestecita de niños mimados» continuase entre profesores, periodistas, guionistas y directores, incluso de generaciones distintas. Quizá porque, en nuestros días, tanto en Italia como en España, la doble vía de error y verdad, invención y realidad, literatura e historia, quiere no solo poner al día una tradición, la tradición, sino también crear o, si se prefiere, recrear un conjunto de tradiciones que tal vez no se perciben como perdidas, sino prácticamente como inexistentes: bien porque se fosilizaron demasiado en el «juego» de las partes enfrentadas, entre el tiempo de las hostilidades y la inmediata posguerra, bien porque fueron congeladas por la censura entre los ańos cincuen-

79 Garosci, Gli intellettuali e la guerra di Spagna, cit., p. 254.

80 Serra, L'esteta armato. Il Poeta-Condottiero nell'Europa degli anni Trenta, cit., p. 135: «Bellísima, cruel expresión: y en verdad España — precediendo al otro golpe terrible que fue el pacto germano-soviético- representó el fin de la fiestecita de niños mimados prolongada durante casi una década».

81 Goffredo Fofi, «Le maschere dell'eroe», revista semanal Film-TV, 8, 2002, p. 114. 
ta y sesenta, y Sciascia ${ }^{82}$ todavía alude a ello en una carta a Erich Linder del 14 de diciembre de 1967, bien porque eran ambiguas y fluctuantes, como en la época posterior a la nueva ley de prensa de 1966 y como sucede, por ejemplo, en San Camilo 1936 (1969), de Camilo José Cela. ${ }^{83}$

Sin duda, en la narrativa española del siglo XX, tomada en su conjunto, la realidad de la guerra civil va mucho más allá de los ultimísimos frutos del siglo XX y de los primeros del siguiente: por ejemplo, la más sincera novela El nombre que ahora digo (1999), ${ }^{84}$ escrita por el hábil periodista y guionista Antonio Soler, o las ya citadas de Cercas y Saura; pero también, en cierto sentido, esa literatura del exilio que madura en las décadas recordadas más arriba, entre la segunda mitad de los ańos treinta y la segunda mitad de los sesenta.

No obstante la «llamada Transición» comience solo con la muerte de Franco, en 1975, abriendo el último cuarto del siglo XX y dando vida en los primeros años de la democracia a «obras en general menos valiosas desde el punto de vista propiamente estético», puesto que solo después de 1982, y en concreto hacia 1986, quincuagésimo aniversario de la guerra, se puede hablar de «una época [...] más interesante y mucho más rica en producciones de todo tipo» (en un nivel narrativo, teatral y cinematográfico). ${ }^{85}$

82 Carta que encuentro citada en Giovanna Lombardo, «Alla ricerca della leggerezza: il carteggio Sciascia-Linder (1963-1983)», Rivista di Studi Italiani, Universidad de Toronto, 1, 2003, p. 101: «Querido Linder: le agradezco las noticias que me da en referencia a las traducciones holandesa y española. Por lo que respecta a esta última, considero que Los tíos habrá que descartarlos por ese cuarto relato (a menos que el editor no haya pensado ya en eliminarlo, como por otra parte han hecho con La muerte de Stalin en los países comunistas: en este caso, los tres relatos pueden unirse a El día de la lechuza)». De lo que se deduce que Leonardo Sciascia preveía todavía la censura en España para El antimonio.

83 Camilo José Cela, Visperas, festividad y octava de San Camilo del año 1936 en Madrid, Alfaguara, Madrid-Barcelona, 1969. Cfr. José Carlos Mainer, "Por un pensamiento que a lo mejor es mentira": la guerra civil en la obra de Camilo José Cela», Bulletin Hispanique, 1, 1992, pp. 250-255.

84 Antonio Soler, Il nome che ora dico (1999), Marco Tropea, Milán, 2003.

85 Sobre el posfranquismo inmediato y el sucesivo, entre la transición y el periodo que sigue a 1982, cfr. Maryse Bertrand de Muñoz, «La guerra civile spagnola nel romanzo, nel teatro e nel cinema dopo la morte di Franco", en AA. VV., Immagini nemiche. La guerra civile spagnola e le sue rappresentazioni (1936-1939), Editrice Compositori, Bolonia, 1999 , p. 150. De la misma autora es justo recordar un estudio precursor, en cierto sentido, de sus posteriores investigaciones todoterreno, comprendida la dedicada a España, ya citada. Pienso obviamente en La guerre civile espagnole et la littérature française, Didier, 
Un asunto distinto, por más que estrechamente ligado, como hemos tratado de sugerir, es el relativo a Italia y la narrativa italiana, a su pasado abierto a posibles «transiciones», a partir al menos de 1945, si pensamos, con los mismos parámetros, en la muerte de Mussolini antes que en el fin de la Segunda Guerra Mundial. Es comprensible que en Italia, durante y después de la Guerra de España, el fascismo imperante no favoreciese experimentos narrativos interesantes y censurase los concebidos en la afortunada encrucijada de la historia y la invención, apoyando en cambio el teatro de propaganda, que fagocitaba el conflicto y lo servía al pueblo con el «tema dominante» de las "violaciones y atropellos de los "rojos"». ${ }^{86} \mathrm{Me}$ consta que incluso en la segunda mitad de los años cuarenta y, sobre todo, en los años cincuenta, aquel pasado no despega, quizá marcado aún por la preponderancia del hombre y de la política sobre el paisaje de la guerra y su sublimación literaria, más o menos urbana, herida.

No por casualidad, Aldo Garosci, ex combatiente, acotando el campo a los intelectuales italianos y avanzando conclusiones, observa a finales de esos años cincuenta: «La política cubre de manera tan exhaustiva la participación del antifascismo en la Guerra de España que prácticamente no hay sublimación literaria de esta experiencia, y resulta también limitada la reflexión crítica». Y en ese "prácticamente» no incluye siquiera, por ejemplo, Il maggiore è un rosso (El comandante es un rojo) (1953), de Francesco Fausto Nitti —autor de Le nostre prigione e la nostra evasione (Nuestras prisiones y nuestra evasión) (publicado en 1930 en francés y en 1946 en italiano)—, que "por mucho que esté escrito con aliento literario, es claramente obra de propaganda y de nostálgica evocación». ${ }^{87}$

Testimonios, diarios, ensayos, estudios, artículos que parecen oponerse directamente - sin el filtro de la ficción, sin una trama que distraiga al lector- a la persuasiva y difusa propaganda fascista, especialmente

París-Montreal-Bruselas, 1972, así como en la ed. española puesta al día de Alfar (Sevilla, 1995). Véanse, en fin, los estudios de la misma y de André Bénit recogidos en el rico volumen de Mercè Boixareu y Robin Lefere (eds.), Histoire de l'Espagne dans la littérature française, Champion, París, 2003, pp. 697-726 y 727-741.

86 Pietro Cavallo, "La guerra di Spagna nel teatro del ventennio fascista», en Francesco Saverio Festa y Rosa Maria Grillo (eds.), La Spagna degli anni '30 di fronte all'Europa. Politica. Storia. Filosofia. Letteratura. Radio. Cinema. Teatro, actas del congreso (Salerno, mayo de 1998), Antonio Pellicani Editore, Roma, 2001, p. 424.

87 Garosci, Gli intellettuali e la guerra di Spagna, cit., p. 453. 
la literaria. Si bien la propaganda (más) literaria, confiada a la narrativa, no es nada del otro mundo y, en esencia, está en manos de diletantes, como mucho periodistas o anónimos profesores y compiladores. Solo por poner un ejemplo, citaré un texto de 1936 no muy conocido: La Spagna in fiamme (España en llamas), cuyo subtítulo reza Todo o nada. De creer al propio autor, Paolo Sighinolfi, debería tratarse de «una narración», tal y como dice en una sucinta nota bibliográfica al final del volumen, donde figuran a la vez, como fuentes de conocimiento e inspiración, España de Edmondo De Amicis y las revistas Gerarchia, Nuova Antologia y Tempo di Mussolini.

Ciertamente, el título novelesco se sostiene gracias a esas llamas que tienen más puntos de contacto con la narrativa decimonónica, finisecular, apocalíptica, que con el reportaje típico del siglo XX practicado por Hemingway. Tanto es así que, retomando una clave de lectura de nuestra discusión, suspendida entre lo antiguo y lo moderno, podríamos pensar en una novelapeplum de 1906, Cartago en llamas, de Emilio Salgari, ${ }^{88}$ más que en las crónicas hemingwayanas dedicadas a la guerra civil española entre el 37 y el 39, incluidas en Enviado especial. ${ }^{89}$ Teniendo presente, sin embargo, que Sighinolfi no es comparable ni a Salgari ni a De Amicis. De este último le cuesta mantener incluso el mimetismo «exótico» de los lugares recorridos y las ciudades visitadas, ${ }^{90}$ y a uno casi le parece estar en Italia, pues numerosas son

88 Cfr. Luciano Curreri, "Il Fuoco, i Libri, la Storia. Saggio su Cartagine in fiamme (1906) di Emilio Salgari», en Emilio Salgari, Cartagine in fiamme, ed. Luciano Curreri, Quiritta, Roma, 2001, pp. 315-403 (Cartago en llamas, trad. A. J. Grassi, ACME, Buenos Aires, 1955). Pero cfr. también, para otros puntos de contacto más o menos subterráneos con el relato ambientado en la antigüedad, Curreri, "Il mito culturale di Cartagine nel primo Novecento tra letteratura e cinema», en Silvio Alovisio y Alberto Barbera (eds.), Cabiria \& Cabiria, Il Castoro/Museo Nacional del Cine, Milán-Turín, 2006, pp. 303-304 y 306. En los ańos del consenso que se desvanece con la prolongación de la Guerra de Espańa y la derrota de Guadalajara en marzo de 1937, la cual arroja una sombra sobre el imperio italiano, la película Escipión el Africano, de Gallone, en el verano de aquel año, entre Roma y Venecia, quiere asimismo levantar los ánimos.

89 Hemingway, By-line, col. Oscar-Scrittori del Novecento, Mondadori, Milán, 1999 (1967), pp. 263-308 (Enviado especial, trad. Agustín Puig, Planeta, Barcelona, 1977).

90 Mimetismo que, más allá de los plagios, es una cuestión todavía abierta, con una bibliografía bien distinta detrás, de Mérimée y Chateaubriand a Custine, Dumas, Didier, Sand y, sobre todo, Gautier con Voyage en Espagne (1843), obra maestra de referencia pero con la que hay que medirse, treinta años después, en un contexto literario realmente diferente. Cfr. Edmondo De Amicis, Spagna, Barbèra, Florencia, 1873 (reed. Franco Muzzio Editore, Padua, 1993) (España: diario de viaje de un turista escritor, trad. Irene Romera, 


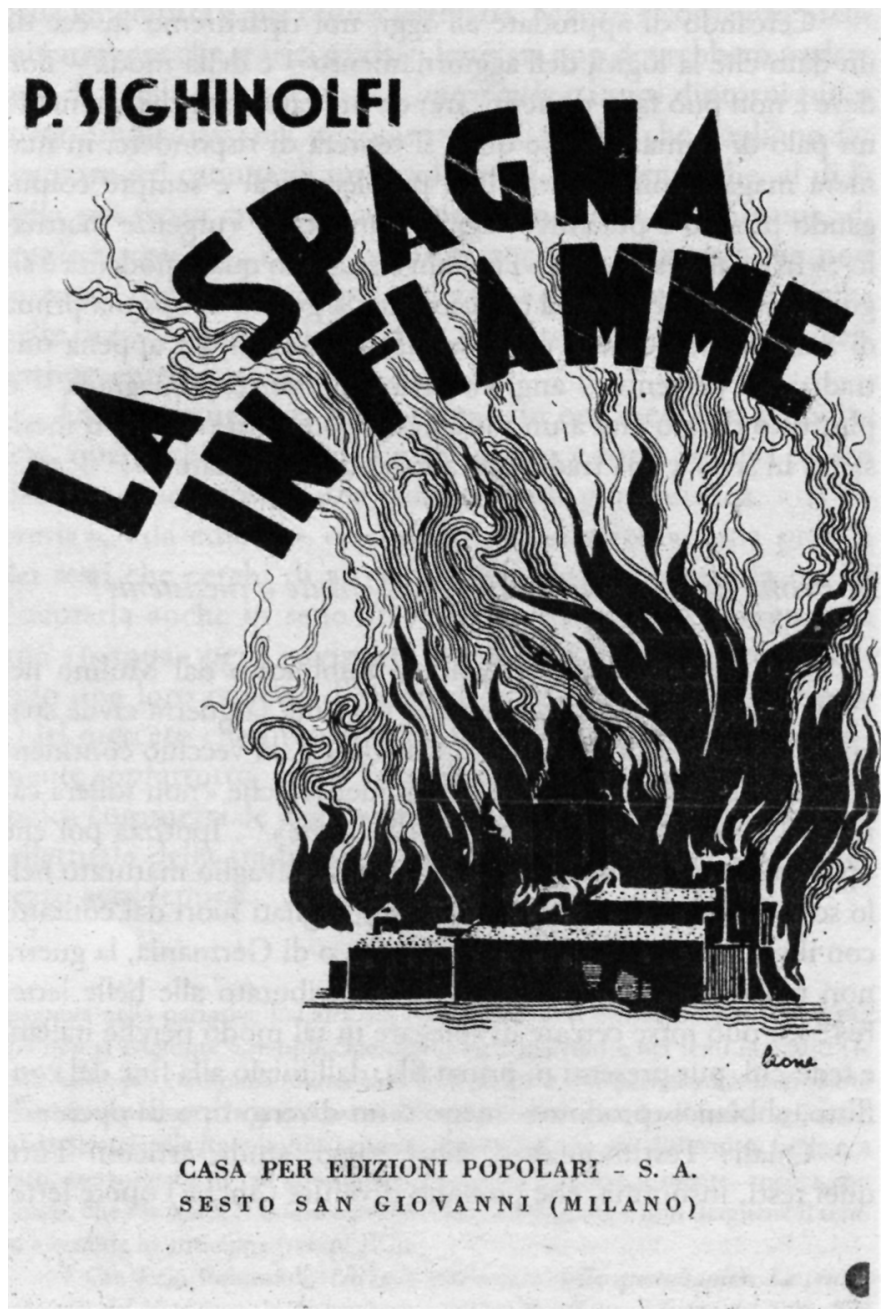


las evocaciones de la "Madre», la "Patria» y los «hombres de camisa negra». Además, las llamas y el fuego no son, como en Emilio Salgari, parte integrante, constitutiva, del modo de concebir la literatura y la historia, y no van mucho más allá de la cubierta blanca de la Casa per Edizioni Popolari, de Sesto San Giovanni, donde despuntan significativamente algunos campanarios negros y edificios semidestruidos de una ciudad envuelta en llamas rojas; y aquí el «rojo» parece también un color político, que carga con la responsabilidad del incendio y la destrucción a comunistas y afines, un poco como en el caso de la "mentira extrema» relativa a Guernica. ${ }^{91}$

Pero no se trata, obviamente, de Guernica, cuyo triste destino no se ha producido todavía en la historia. Se trata, casi seguramente, de Madrid. Por otro lado, el libro de Sighinolfi contiene el epílogo "iMadrid liberado!», fantacientífico para 1936 pero que dan por descontado casi todos los observadores, que creen en la inminente caída de la capital. Es más: algunos corresponsales portugueses e ingleses - amplificando un dato de falso reportaje sobre el que volveremos, escrito en el verano de 1936 por El Gringo-Vittorini, en el que Inglaterra habría pagado, a través de Portugal, el avance hacia Madrid - preparan anticipadamente el relato de la entrada victoriosa del ejército nacional en la capital, igual que Sighinolfi:

¡Madrid, estrechado el cerco de fuego, ha caído! La trágica hora, que ha desgarrado Espańa y colmado el mundo de horror, está a punto de acabar.

Los nacionales han entrado en Madrid tras el éxodo del gobierno revolucionario y sus secuaces. nales. ${ }^{92}$

Al fin, la gran batalla por Madrid ha sido ganada por las tropas nacio-

Cátedra, Madrid, 2000). Pero véase al menos Bianca Danna, Dal taccuino alla lanterna magica. De Amicis reporter e scrittore di viaggi, Olschki, Florencia, 2000, p. 32, y Madrignani, "Una "favola” spagnola», en Edmondo De Amicis, Manuel Menéndez, Sellerio, Palermo, 1991, pp. 9-33; se trata de un cuento tomado de la 2. a ed. aumentada de las Pagine sparse, Tipografia Editrice Lombarda, Milán, 1876 (1874).

91 A propósito del «rojo» cfr. también la novela de Renzo Chiosso Voragine rossa, Pia Società San Paolo, Alba, 1937; para Guernica, Bennassar, "Mensonges extrêmes: "L'incendie" de Guernica et le "fascisme" du POUM», en La guerre d'Espagne et ses lendemains, cit., pp. 331-332.

92 Paolo Sighinolfi, «Madrid liberata!», en La Spagna in fiamme (Todo o nada), Casa per Edizioni Popolari A. Barion, Sesto San Giovanni (Milán), 1936, p. 247. Pero cfr. Bennassar, "La bataille de Madrid», en La guerre d'Espagne et ses lendemains, cit., p. 158: "Cuando se desata, a finales del mes de octubre de 1936, la batalla de Madrid, la iniciativa es de las tropas nacionales. Las milicias y los restos del ejército regular que combaten por la República están a la defensiva, y el desenlace de la lucha parece tan evidente como cer- 
Aparte de este epílogo, con tres años de adelanto, Paolo Sighinolfi logra de todos modos relatar con ambigüedad, unilateralmente, el comienzo del fin, fotografiando la efímera entente entre comunistas soviéticos y anarquistas. Si bien los dos grupos, un poco como los «rojos» del teatro de propaganda, están unidos —o reunidos — a la hora de destruir, pegar fuego y dejar tierra quemada a las "pacíficas» fuerzas de liberación nazifascistas.

Sobre Madrid se desata todavía el odio diabólico de los cabecillas soviéticos, quienes, de acuerdo con los dirigentes del movimiento anarquista español, hoy en el gobierno, quieren reducir la capital madrileña a un montón de ruinas con una fosa común, antes de huir. ${ }^{93}$

Pero la estructura de España en llamas es interesante no solo por este epílogo, profético a largo plazo — los franquistas entrarán en Madrid el 28 de marzo de 1939—, sino también porque está dirigida en su totalidad a registrar a lo largo de sus siete capítulos más el epílogo los miedos, mitos y sueños de la derecha — y de la Iglesia - en 1936, con itinerarios que llegarán a ser lugares comunes del imaginario fascista y que van de la «Tormenta sacrílega» al "Alcázar», del «Alcázar» a «iMadrid liberado!». ${ }^{94}$

Por lo demás, este recorrido casi ejemplar, centrado en el Alcázar, ${ }^{95}$ no dejará de traernos a la mente la trama del largometraje premiado en la Mostra de Venecia de 1940: Sin novedad en el Alcázar, de Augusto Genina. ${ }^{96}$

cano. [...]. El 19 de octubre, Franco ordena de nuevo el avance sobre la capital. Casi todos los observadores creen en su inminente caída, y algunos corresponsales de guerra portugueses y anglosajones redactan de antemano los despachos sobre "la entrada victoriosa" de las tropas franquistas». El mismo Bennassar remite luego a Paul Preston, Franco. A Biography, Harpers Collins Publishers, Londres, 1993 (Franco, caudillo de España, trad. Teresa Camprodón y Diana Falcón, RBA Coleccionables, Barcelona, 2005).

93 Sighinolfi, La Spagna in fiamme (Todo o nada), cit., p. 249.

94 Ib., pp. 151-183, 211-234 y 245-250.

95 Cfr. a este propósito Pietro Caporilli, L’assedio dell'Alcazar, pról. del protagonista, general José Moscardó, Unione Editoriale d'Italia, Roma, 1940; en particular, los capítulos que van desde «El bautismo de fuego" (pp. 57-65) hasta «Infierno en el círculo de hierro y fuego" (pp. 89-102). En la bibliografía de Caporilli precede a este libro el ya citado Spagna rossa, Ardita, Roma, 1938. Sobre las vicisitudes del Alcázar vuelven luego, entre finales de los años treinta y comienzos de los cuarenta, numerosos textos partidistas, como, por ejemplo, los de Valerio Pignatelli, I cadetti del Alcazar. Romanzo, Sonzogno, Milán, 1937, y Alberto Bargelesi, L'epopea dell'Alcazar, Istituto di Propaganda Libraria, Milán, 1941. Pero véase el desarrollo de nuestra argumentación.

96 Cfr. Corrado Di Vanna, "L'assedio dell'Alcazar. Un film de A. Genina», Revue Belge du Cinéma, 17, 1986, pp. 49-52. 
Una película que, a las vicisitudes colectivas, superpone una simbólica historia de amor entre el capitán de la ciudad-fortaleza de Toledo y una muchacha de Madrid, con la consabida evolución dramática. La de Genina tenía que competir en aquella ocasión con Más allá del amor, de Carmine Gallone, otra gran producción de la Mostra a la enseña del binomino amor/patria, con dos actores de la talla de Alida Valli y Amedeo Nazzari en los respectivos papeles de la hija de un noble romano y un carbonario de comienzos del siglo XIX. Todo basado en hechos reales. Pero recordemos Madridgrad, las obsesiones de los sublevados y los exorcismos que en aquellos años las sanan.

Del Alcázar a Madrid, pues, con pasión, pero casta y simbólica, en un marco de credos y avemarías. Como lo prueba, de acuerdo con la «narración" de Sighinolfi, un trabajo teatral de 1937: Per la Croce. I cadetti dell'Alcazar (Por la Cruz. Los cadetes del Alcázar), de Romeo Rivalta, un actor profesional y fascista de primera hora que solo unos meses más tarde puede ya sacar a escena un frente enemigo desarticulado. Es cierto que no se representan los profundos desencuentros entre comunistas y anarquistas -extremistas todavía percibidos en bloque y contrapuestos a los moderados, entonces en sintonía con los nacionales- pero se enuncian miedos, mitos y sueños de la derecha y de la Iglesia a propósito de la guerra civil española.

Vete al diablo tú, la anarquía, la conciencia individual, los derechos del hombre y el sol del porvenir. ¡Basta! ¡Basta! ¡Vuelvo al Credo y al Ave María, donde me encuentro mejor! ${ }^{97}$

En fin, los itinerarios de Sighinolfi, sobre todo los comprendidos entre la "Tormenta sacrílega» y el «Alcázar», hacen pensar en un horizonte ideológico impregnado de Cruz y de cristiandad «a buen precio», más propio de la nota de prensa o de la propaganda teatral — quizá no siempre ni completamente roma- que de una verdadera novela popular. Lejana del exotismo decimonónico, más pagano que cristiano, y de la tensión apocalíptica de Salgari, España en llamas (1936) se aproxima, pues, a ciertas operaciones narrativas tan dudosas como sospechosas de la segunda

97 Cfr. Cavallo, La guerra di Spagna nel teatro del ventennio fascista, cit., p. 419. 
mitad de los años treinta — difundidas en el ámbito católico-, verbigracia Il Mediterraneo in fiamme (El Mediterráneo en llamas) (1939) de Emilio Garro. ${ }^{98}$

Las llamas quedan, pero la España pagana — la de Richard Wright ${ }^{99}$ en Pagan Spain (1957) y la del mismo Hemingway- se aleja, esfumada en una apoteosis de Roma: pagana también, pero, sobre todo, cristiana. Concluida la guerra civil, al otro extremo de su cronología, se publica $E l$ Mediterráneo en llamas, novela histórica ambientada en el siglo XIV con su correspondiente triunfo cristiano final ${ }^{100}$ - la victoria de la Liga Santa contra los turcos en Lepanto en tiempos de Pío V (1571)—, pero proyectado más o menos sobre el mismo horizonte ideológico de Il Mediterraneo, revista ilustrada que desarrolla «una burda y descarada propaganda fascista» y que ofrece, entre otras cosas, "pies de foto bilingües, en italiano y en español, muchas de las cuales celebran las victorias fascistas en España». ${ }^{101}$

Paolo Sighinolfi y su «narración» española encajaría entonces en ese intenso y decisivo contexto histórico-político que Renzo De Felice analiza en relación con la postura "claramente a favor de Franco» de la cultura clerical italiana, "desde las más altas jerarquías hasta sus más bajos niveles», a partir de las fulminantes indicaciones dadas en julio de 1936 por L'Osservatore Romano, en cuya "estela» se mueve «la gran mayoría de la prensa católica» ${ }^{102}$ y que figura en la sucinta nota bibliográfica de España en lla-

98 «De ese modo, con el triunfo de Lepanto, eclipsada la Media Luna, volvió a lucir sobre las aguas del Mediterráneo la Cruz y, con ella, la Civilización cristiana y latina de Italia y de Roma». Cfr. Emilio Garro, Il Mediterraneo in fiamme, S. E. I., Turín, 1939, aunque citamos a partir de la 2. ${ }^{\text {a }}$ ed. de 1941, p. 370.

99 Richard Wright, Spagna pagana, Mondadori, Milán, 1962 (1957), y en col. I Record, 1966, p. 307: «Puesto que tenía ya la profunda sensación, la seguridad incluso, de que España no era una nación occidental, ¿qué quería decir, entonces, ser occidental? (¿y la república? ¿la guerra civil? ¿los anarquistas?; también estos hechos, a la luz del carácter no occidental del país que había visto, resultaban profundamente distintos y menos importantes) [...]. En España no existía una vida laica, profana. España era una nación religiosa, un Estado sacro, sacro e irracional como el de los akan en la jungla africana. También la prostitución, la corrupción, la economía y la política tenían algo de sacro. En España, todo era religioso» (en cursiva en el original) (España pagana, trad. Salvador Guerra, Orígenes, Madrid, 1988).

100 Emilio Garro, Il Mediterraneo in fiamme, cit., pp. 359-370.

101 Cfr., a este propósito, Giuditta Isotti Rosowsky, introd. a Un'amicizia senza corpo. La corrispondenza Parisot-Savinio 1938-1952, Sellerio, Palermo, 1999, p. 19.

102 Renzo De Felice, «La politica fascista nelle sabbie mobili spagnole», en Mussolini il duce. Lo stato totalitario 1936-1940, Einaudi, Turín, 1981 (col. Tascabili, 1996, p. 376). 
mas. ${ }^{103}$ Por lo demás, la producción coetánea a Sighinolfi parece confirmar el dato del célebre historiador: preceden, en efecto, a España en llamas títulos como Il cardinale Lambertini (Benedetto XIV) (El cardenal Lambertini [Benedicto XIV]) y Don Bosco: il salvatore di anime (Don Bosco: el salvador de almas), ambos de 1935. ${ }^{104}$

En los años treinta y, más en general, en las dos décadas del periodo de entreguerras, tanto en Italia como en España (y en Francia) se desarrolla un intrincado y complejo proceso de rivalidad y ósmosis entre —según el mapa que traza un libro reciente- la politización de lo religioso, querida por la Iglesia, y la sacralización de la política, querida por los totalitarismos. ${ }^{105}$ Además, 1935 es el año de las sanciones: el año en que otros mares, además del Nostrum, están en el centro de los intereses italianos y fascistas. Y es el año de El águila lejana, novela de la «habilísima Olga Visentini, que definió el perfecto libro fascista para los nińos, narrando, en una lengua por lo demás atractiva y pulcra, las cultas y refinadas peripecias de un jovencísimo patricio que va a recuperar a su padre, prisionero en las Galias». ${ }^{106}$

103 Sighinolfi, La Spagna in fiamme (Todo o nada), cit., p. 251.

104 Publicados por ediciones Aurora. Cfr. también, significativamente, Emilio Garro, Cento anni fa: azioni sceniche sulla vita di Don Bosco e sul Natale, S. E. I., Turín, 1941.

105 Cfr. el rico libro de Daniele Menozzi y Renato Moro, Cattolicesimo e totalitarismo. Chiese e culture religiose tra le due guerre mondiali (Italia, Spagna, Francia), Morcelliana, Brescia, 2004. Se divide en tres partes, dedicadas respectivamente a "Autoridad», "Nación» y «Unidad», todas importantes pero especialmente la primera, que debe leerse por entero. Véanse en particular, para la primera, Alfonso Botti, «La Iglesia frente a un régimen autoritario. La dictadura de Primo de Rivera como "ocasión perdida"», pp. 75-123; para la segunda, Carmelo Adagio, «Una liturgia para una nación católica. La Iglesia española y las lecturas providencialistas de la dictadura (1923-1930), pp. 171-196; y para la tercera, Renato Moro, "El mito del imperio en Italia, entre universalismo cristiano y totalitarismo", pp. 311-371.

106 Cfr. Olga Visentini, L’aquila lontana, Mondadori, Milán, 1935. Hojéense las habituales, triunfalistas páginas que cierran el último capítulo, "Veo el sol», pp. 187-194. La cita está tomada de Antonio Faeti, «Un tenebroso affare. Scuola e romanzo in Italia», en Franco Moretti (ed.), Il romanzo, I. La cultura del romanzo, Einaudi, Turín, 2001, p. 123. Cfr. además, a propósito del libro infantil en el fascismo, Adolfo Scotto Di Luzio, L'appropriazione imperfetta. Editori, biblioteche e libri per ragazzi durante il fascismo, Il Mulino, Bolonia, 1996, que llama la atención sobre Visentini en cuanto autora de Libri e ragazzi, Mondadori, Milán, 1936, y Scrittori per l’infanzia, ib., 1943. Para el águila (imperial y dantesca), cfr. Simona Urso, "L'aquila imperiale e il veltro dantesco. Il fascismo come orizzonte messianico", en Cattolicesimo e totalitarismo. Chiese e culture religiose tra le due guerre mondiali (Italia, Spagna, Francia), cit., pp. 247-274. 
Pero 1935 es también el año en que un narrador como Ignazio Silone comienza a escribir las páginas dedicadas al viejo Don Benedetto -incluidas aquellas, invariables, sobre el comportamiento político de la Iglesia y sus jerarquías - en Pan y vino, recogidas veinte años después bajo el título, más conocido, de Vino y pan. ${ }^{107}$ Mientras la propaganda de derechas se convierte en profecía futurista — con poca intuición literaria y mucha inconsciencia política-, dando por descontados sucesos previsibles en 1936 pero destinados a hacerse realidad solo años después (como en toda profecía que se precie, por lo demás), la historia no halla, del otro lado del frente, un verdadero enganche con la invención, especialmente, como dijimos, en aquellos diarios y estudios que son hijos de la experiencia madurada por italianos y alemanes en el enfrentamiento con el fascismo y el nazismo en España.

Con todo, en el horizonte de los años treinta y cuarenta surgen numerosas obras narrativas, percibidas como tales por los lectores y quizá por los mismos autores, a pesar de que su mayor o menor componente novelesco parezca sucumbir ante las aportaciones autobiográficas ligadas al conflicto español (pensemos, de nuevo, en Koestler). Pero la expresión "estamos en guerra» puede también leerse como "érase una vez la guerra civil española» porque los escritores a tiempo completo, aun siendo muy distintos entre ellos, como Malraux, Orwell y Hemingway, en seguida intentan conciliar la historia con la invención, con el imaginario, y no precisamente para hacer desaparecer la historia en la literatura: su literatura nace de la memoria, pero no quiere yacer en ella como testimonio, diario, ensayo, estudio, artículo más o menos parcial. Así se puede recuperar el pasado, incluido el más reciente, y al mismo tiempo creer en la operación narrativa: Madrid existía, Madrid existe.

Cierta retórica autobiográfica, volcada de manera barroca o romanticoide, puede incluso negarnos el placer de leer de un tirón y sin prejuicios Por quién doblan las campanas (1940), de Ernest Hemingway, y dirigir nuestra atención hacia la más evidente pasión literaria y civil de Homenaje a Cataluña (1938), de Orwell —o de Les grands cimetières sous la lune

107 Cfr. Ignazio Silone, Vino e pane, Mondadori, Milán, 1955; y en col. Oscar, 1981, pp. 23-52 (Vino y pan, trad. Carmen Martín Gaite, Alianza Editorial, Madrid, 1968). 
(Los grandes cementerios bajo la luna) (1938), de Bernanos. ${ }^{108}$ Sin embargo, es oportuno tener en cuenta que, tanto en Hemingway como en Orwell, tras las vicisitudes colectivas emerge «un acto extremo de individualismo", ${ }^{109}$ de todos modos, un tanto retórico, especialmente al calor de la guerra, sea respecto de la ideología, sea respecto de la literatura en sí. Por esa razón no es desencaminado partir de las quinientas páginas de Por quién doblan las campanas, sobre todo si se quiere leer una novela que ha marcado el imaginario de un siglo; pasando luego al otro coloso, La esperanza, de Malraux.

Claro, que no se trata de seguir, adoptando superficialmente modas o recorridos hermenéuticos más o menos recientes, el desarrollo narrativo del siglo XX traducido en cine - para nacionales y republicanos, inherente sin embargo a la guerra civil-,${ }^{110}$ sino de remontarse brevemente al origen de algunos caminos que la narrativa en general - y la italiana en particular - ha privilegiado en referencia a la Guerra de Espańa; incluida la poco conocida pero "natural compañía» de novelistas españoles — por ejemplo, Ramón J. Sender y su Mosén Millán (1953), reeditado en 1960 bajo el título Réquiem por un campesino español-, cuyo valor y destino literarios deben medirse también en función de la más amplia y emblemática incidencia de los poetas en los años del conflicto, la inmediata posguerra y más adelante.

Basta pensar, a este propósito, en la elaboración y la estructura de un ensayo — todavía hoy muy importante- como el citado de Aldo Garosci, Los intelectuales y la Guerra de España, publicado en 1959 por Einaudi, un año antes de la segunda edición de Los tíos de Sicilia. ${ }^{111}$

108 Sobre el que volveremos en el tercer capítulo, en relación con Tabucchi y Sostiene Pereira.

109 Cfr. Maffi, epílogo a Orwell, Omaggio alla Catalogna, cit., p. 255. Pero sígase el desarrollo de nuestra argumentación en el texto.

110 Para el bando nacional e italiano, piénsese en cuanto se dijo acerca de Sin novedad en el Alcázar, de Augusto Genina; por la parte republicana y francesa, consúltese André Malraux, Espoir. Sierra de Teruel (1938-1939), guión de la película, introd. François Trécourt, nota Noël Burch, col. Folio, Gallimard, París, 1996. Véase además, para un panorama de conjunto, Marcel Oms, La guerre d'Espagne au cinéma, cit. Pero cfr., fundamentalmente, "La guerre d'Espagne vue par le cinéma», Les Cahiers de la Cinématheque, 21, 1977; y «La guerre civile d'Espagne et le cinéma», Revue Belge du Cinéma, 17, 1986.

111 Cfr. una vez más Garosci, Gli intellettuali e la guerra di Spagna, cit., que sin embargo dedica un capítulo a Ramón J. Sender, pp. 160-178, si bien ni en el texto ni en la biblio- 
Obedeciendo a un plan —o por instinto—, Garosci sitúa el discurso sobre esos intelectuales en "Apéndice», de la misma manera que los «deseos» de Orwell nos conducen a leer «las partes más políticas y menos narrativas» de su novela española como "apéndices». ${ }^{12}$ Los límites de esta recepción histórico-literaria —asumidos, por otro lado- son los que El antimonio de Sciascia, a su modo, intenta superar, conciliando historia e invención para, de ese modo, trascender el punto de vista del intelectual "meridionalista»," que un escritor importante como Francesco Jovine había fijado quince años antes en un relato más breve, «Michele a Guadalajara» («Miguel en Guadalajara»).

Respecto a El antimonio, este texto, tercero de los contenidos en L'impero in provincia. Cronache italiane dei tempi moderni (El imperio en provincias. Crónicas italianas de los tiempos modernos) (1945), tiene un título y un desarrollo menos sugestivos, inscritos directamente en la historia de las relaciones entre el imperio italiano, el espíritu fascista, y una arcai-

grafía (p. 469) cita la 1.a ed. mejicana de 1953 ni la 2. a ed. norteamericana de 1960, aquel Mosén Millán que se difumina en un anonimato casi sciasciano, al menos en el título, al convertirse en Réquiem por un campesino español. Es notable el punto de partida de Garosci, empeñado luego en separar en Sender el reportaje realista de la obra narrativa propiamente dicha, en beneficio, como se sugería más arriba, de la estructura del libro, dejando a los poetas —al menos inicialmente- la parte del león. Pero, repito, el comienzo es notable y hace pensar en Sciascia, especialmente por un par de datos (que Sender vuelva sobre la Guerra de España y que evoque a Azaña, a quien Garosci dedica un capítulo, pp. 89109): «Pero la lenta tenacidad y el modo cauto, casi indirecto, con que el escritor vuelve sobre los temas de la guerra española, están indicando un pesar más intenso, una fidelidad distinta y más fina, aunque no menos completa, a los motivos de su exilio. De esta manera, pensamos que no es casual que Sender nos haya brindado, junto con Azaña, la mayor creación nacida de las vicisitudes de la guerra civil». Además, el Réquiem por un campesino español —réquiem por Paco, homenaje a su memoria realizado por el cura Millán-, en su forma más de relato largo que de novela, en contraste con la amplitud y acaso la prolijidad de otras obras de Sender, responde muy bien a aquellas observaciones de Garosci y a una síntesis, diríamos de nuevo, sciasciana, que se acerca, en tal sentido, a la textualidad «acabada» de El antimonio (1960). No estaría mal reeditarlo para el público italiano, junto al Réquiem (1960), en un librito que tratase de ilustrar las respectivas aproximaciones. Cfr., finalmente, el breve pero intenso prólogo de Hubert Nyssen, «Pour qui sonnait le glas», a Ramón J. Sender, Requiem pour un paysan espagnol, ed. Bernard Lesfargues, Actes Sud, Arles, 1990, pp. 7-10.

112 Cfr. George Orwell, Omaggio alla Catalogna, ed. Riccardo Duranti, Mondadori, Milán, 2002 (1938), p. 2.

* N. de los T.: En defensa de la cultura propia de las provincias del sur de Italia (Meridione). 
ca, perezosa, cuasi «abocetada» Italia del sur. La historia oscila entre dos polos, dos registros: el drama y el ridículo. Este último, sin embargo, no "traduce» ${ }^{113}$ el drama, sino que se puede rastrear mejor dentro de esa tradición que ambiguamente acompaña la burla al sufrimiento, dentro del cual la guerra civil espańola pierde relevancia.

De Guadalajara, de hecho, el relato no dice prácticamente nada, ${ }^{114}$ porque cuentan solo el prólogo y el epílogo, o sea (esquematizando) el drama, que implica el desempleo y tener que salir como voluntario a la guerra, y el final ridículo, que no amplifica esos datos sino que los difumina y anula en cierto modo: el protagonista no solo pierde un brazo en la guerra —el de Sciascia, una mano_-, sino que además resulta burlado por "Ángel, el zapatero», quien «durante su ausencia [...] tanto ha hecho por él» ocupándose de su mujer y de su familia en todos los sentidos. ${ }^{115}$

Está, claro, la necesidad de "contar [...], contar siempre», ${ }^{116}$ como en Sciascia, pero no se sabe bien qué ha sucedido en España y el conocimiento que de ello se tiene es solo íntimo, privado, no histórico o colectivo (ni quiere serlo a partir de la guerra). El punto de llegada es, una vez más, el pueblo, la provincia, el sur, elementos a los que el relato y el personaje de Jovine permanecen anclados.

El protagonista de El antimonio, tras volver de España, habla verdaderamente de la guerra, pone en juego su conocimiento, lo hace histórico y colectivo, y luego decide partir, dejar el pueblo, la familia, para

113 Cfr. una vez más Jankélévitch, L'Ironie, cit., pp. 9-19 y 129-143.

114 Salvadas las debidas distancias, dadas las distintas épocas que ven nacer ambos textos, a medio siglo uno de otro: 1945 y 1996, de la Guadalajara de Jovine no sabemos nada, como no sabemos nada de la Guernica de Lucarelli. Cfr. Carlo Lucarelli, Guernica, Il Minotauro, Milán, 1996 (trad., con título homónimo, de Miguel Edo, Edhasa, Barcelona, 2000), y cuanto se dirá en el tercer capítulo de este libro. Pero en Jovine son otros elementos los que urgen por salir: el sur, la provincia, mientras que en Lucarelli no se advierte ninguna urgencia histórica, histórico-cultural, y el divertimento propio del polar, del género negro, dispone con desenvoltura una atmósfera apocalíptica mediante rápidas evocaciones de escritores famosos, personajes de la época, películas, etcétera.

115 Francesco Jovine, "Michele a Guadalajara», en L'impero in provincia. Cronache italiane dei tempi moderni, Einaudi, Roma, 1945; y en col. Nuovi Coralli, Einaudi, Turín, 1981, p. 75. Para la contextualización general del relato, cfr. Giovanni Arpino y Lidia De Federicis, Il novecento. Antologia della critica letteraria e dei narratori e poeti italiani, Petrini, Turín, 1971, pp. 258-275.

116 Jovine, «Michele a Guadalajara», cit., p. 74. 
ver cosas nuevas; Miguel, en cambio, se queda en el pueblo y acaba prisionero, rodeado de moscas, como los viejos (un poco a la manera de Brancati):

No sabía bien qué había sucedido en Guadalajar, pocos días después; habían llegado carros blindados como para aplastarle los huesos al enemigo.

Y, en cambio, los soldados del otro lado habían saltado como diablos encima de los primeros carros, con botellas de gasolina y bombas de mano: primero se habían detenido los carros, luego habían explotado muchas bombas a su alrededor; uno había gritado: ¡Italianos, hermanos!; y Miguel moría. Cuando se despertó, estaba en una casa de campo; le pareció resucitar; tenía la fiebre altísima, estaba cargado de vendas y sentía que le mordía el brazo una jauría de perros rabiosos.

[...]

El primero que le viene al encuentro es Ángel, el zapatero, que le palmea la espalda como si quisiera adueñarse de él una vez más. Ángel habla, le cuenta de Rosalba y de los niños, especialmente del que ha nacido durante su ausencia; se muestra amigable: ha hecho tanto por él.

- Todo lo ha hecho por él — dice un campesino que les acompaña, guiñando un ojo con picardía.

—Un brazo —dice Ángel—, ¿qué es un brazo? Parece una desgracia, y en cambio puede ser una suerte. ¿̇s el gobierno quien te ha mandado a la guerra? El gobierno te mantendrá. Irás tirando sin trabajar.

[...]

Ángel le volvió la espalda y se marchó: Miguel pensó que sería inútil seguirle [...]. Miguel dejó el cuchillo sobre la mesa y bajó al descampado delante de la casa; se quedó inmóvil, sentado sobre una tapia derruida. Solo de vez en cuando se chafaba las moscas que se le posaban en la cara y pensaba que a los viejos les rondan tantas moscas como poca es su fuerza para aplastarlas. ${ }^{117}$

Claro que no se vacía de drama — hay más Verga que D’Annunzio cuentista (presente, en cualquier caso, en el tono sensual de la primera parte)_, pero tampoco este se vuelve absoluto, mítico, como ocurre en Leonardo Sciascia, donde la mutilación es muerte y renacimiento al mismo tiempo, fin y principio del héroe y del narrador, más allá del regreso, del pueblo y sus inmóviles coordenadas. De ese modo la invención no se rinde ante la historia, sino que se concilia con ella y la metamorfosea, para siempre, en escritura, en una literatura que se evade de la crónica y "quiere ver cosas nuevas». Viene a la mente Robert Jordan, quien - tras comparar a los aviones con los tiburones de la corriente del Golfo, solo

117 Ib., pp. 75-77. 
que menos naturales en sus movimientos, endurecidos por «un destino mecanizado» — se dice a sí mismo: «Deberías escribir [...]. Quizá un día volverás a escribir». ${ }^{118}$

En Jovine, en cambio, la oscilación un tanto ambigua de la historia de Miguel, y otras de El imperio en provincias, pueden hacer pensar más que en El antimonio en una película de Luigi Zampa, Los años rugientes (1962), que es, dentro de la comedia a la italiana, «la mejor película sobre el tema [el fascismo alborotador de provincias, camisas negras y concentraciones espontáneas], libremente inspirada en El inspector de Gogol [argumento de Amidei, Talarico y Zampa, guión de Maccari, Scola y del mismo Zampa], donde los habitantes de una pequeña ciudad pullesa creen ver en un tímido agente de seguros (Nino Manfredi) a un inspector del partido de incógnito, al que tratan como a un semidiós, al menos mientras no se descubre la verdad». ${ }^{119}$

Los años rugientes se mueven, pues, en la estela de la comedia a la italiana pero con los límites de un final amargo, revelador, anticipado aquí y allá de modo gracioso, divertido pero significativo, también en relación con la guerra civil española.

A los pobres parados de Jovine $-\mathrm{y}$ luego de Sciascia-, ${ }^{120}$ que protestan por un deshaucio injusto y por la crónica falta de trabajo, el alcalde fascista Salvatore Acquamano, interpretado por un extraordinario Gino Cervi, les aconseja partir como voluntarios para España. La réplica de uno de los ofendidos no asimila la rabia "meridionalista»* —en última instancia, tardoneorrealista - del final de la película, antes bien, la difumina en una ocurrencia cómica pero interesante: «Marchaos vosotros a España. Yo acabo de volver de África».

118 Hemingway, Per chi suona la campana, cit., p. 95.

119 Enrico Giacovelli, La commedia all'italiana, Gremese, Roma, 1990, p. 45. Hay que recordar en seguida, al menos en nota, que Zampa fue quizá el único —en colaboración con Brancati- en representar, desde los años cuarenta, la continuidad entre los régimenes fascista y democristiano. Pensamos obviamente en el díptico Años difíciles (1948)/Años fáciles (1953), al que en breve aludiremos.

120 Coco, Jovine, Sciascia e la guerra di Spagna, cit.

* Véase N. de los T. en p. 141. 
A su modo, la película ofrece una salida feliz, significativa, que no casualmente introduce esa África que, con otra intención, había ya evocado y denunciado literariamente Silone en la citada Vino y pan:

En el vagón atestado de jóvenes llamados a las armas, dos señores con el distintivo del partido hablaban de la guerra. Los demás viajeros callaban y escuchaban.

«Con los inventos de que dispone nuestro ejército, verás que la nueva guerra de África acaba en pocos días", decía uno. «El "rayo de la muerte" carbonizará al enemigo».

Se sopló con los carrillos hinchados la palma de la mano, como para dispersar el polvo, dando a entender: «será barrido así».

«¿Has leído que los reservistas de Avezzano serán hoy bendecidos por el obispo?» dijo el otro. "Verás, el "rayo de la muerte" abrirá el camino incluso a los misioneros».

[...]

También el paisaje se había puesto el uniforme. [...]. La aldea parecía irreconocible bajo una decoración multicolor de órdenes de concentración, festones, banderas, pintadas en los muros [...]. Un grupo de hombres con el distintivo, roncos ya de tanto hablar, discutían en torno a una mesa los detalles de la demostración espontánea que tendría lugar por la tarde. Debía asegurarse, con rígidas y severas precauciones, la participación entusiasta de toda la población de Fossa y alrededores.

[...]

El empleado de la oficina del registro, don Genesio, tras haber hojeado las listas de las peticiones de enrolamiento voluntario, había exclamado:

«Esta será la guerra de los desposeídos». ${ }^{121}$

La guerra de África no queda tan lejana de Los años rugientes, aunque no sea la protagonista, como en Silone, y haga como de contrapunto de la Guerra de España en la citada ocurrencia, que, en ese sentido, se carga cuando menos de cierto realismo. La guerra colonial en Etiopía acaba el 5 de mayo de 1936, y la guerra civil española estalla el 17 de julio, con la revuelta militar en Marruecos. El fascismo se hunde en África. E Italia vuelve a interesarse por el Mediterráneo occidental, desde el estrecho de Gibraltar a las Baleares, como tendremos ocasión de repetir, ${ }^{122}$ haciendo

121 Silone, Vino e pane, cit., pp. 272, 273-274, 275. Léase todo el capítulo XX, pp. 272-292.

122 Remito desde este momento a un documento de época, de gran interés, y reeditado recientemente: Camillo Berneri, Mussolini alla conquista delle Baleari (1937-1938), pról. Claudio Venza, epíl. Giuseppe Galzerano, Galzerano, Casalvelino Scalo (Salerno), 2002. Sobre el autor, cfr. Carlo De Maria, Camillo Berneri. Tra anarchismo e liberalismo, Angeli, Milán, 2004; en particular, las rápidas anotaciones sobre el «Exilio», pp. 153-157. 
inútiles ciertas previsiones españolas de un año antes, verano-otoño de 1935, relativas a la invasión italiana de Etiopía. Sugiere Jean-François Berdah: "¿No habría sido más sensato para España unir su destino al de las grandes potencias, a la espera de una decisión conjunta? Además, al ganar la causa de Etiopía, Italia se apartaría del oeste del Mediterráneo, donde una modificación pacífica del status quo parecía todavía posible» (con «la política española de reivindicación de Tánger»). ${ }^{123}$

En Italia, ya en 1936, los caminos del fascismo acaban por resultar «infinitos». La «fe» de los italianos es sometida a una dura prueba. Política y geografía se entrecruzan desde África meridional hasta Italia del sur, desde el imperio hasta las provincias, y luego desde Melilla, en la franja magrebí, hasta España. Unidades italianas llegan allí solo a fines de 1936, pero les siguen contingentes de voluntarios en paro y después, todavía, los procedentes del reclutamiento oculto, por el que a los pobres desempleados se les hacía creer que partían para Etiopía, de donde muchas familias, hartas de heroísmos y batallas, esperan, durante el largo verano de 1936, la vuelta de los veteranos.

Es para reírse si no fuera para llorar; no es la risa resultante de un proceso irónico, controlado, de ridiculización, sino el más simple e inmediato reír para no llorar. ${ }^{124} \mathrm{El}$ drama de Los años rugientes, en definitiva, vuelve la espalda al ridículo, del que también se ha servido para hablar del fascismo, pues se ve casi obligado, un poco como Jovine, a caballo entre la provincia y el imperio, entre Etiopía y España, a poner punto final con el inmovilismo del pueblo, manifiesto en la carta de un viejo que vive todavía en una cueva y pide al duce una ventana, antes que una casa, trayendo a colación a su hijo caído en África. Por otro lado, la película de Zampa

Sobre la disputa del Mediterráneo, cfr. el ya recordado Palacio, 1936: La Maldonne Espagnole. Ou la guerre d'Espagne comme répétition générale du deuxième conflit mondial, cit., pp. 223-303.

123 Cfr. una vez más Jean-François Berdah, "L'Espagne au coeur des tensions européenes», en La démocratie assassinée. La République espagnole et les grandes puissances. 19311939, cit., pp. 105-204; en particular las pp. 155-169: «Del rearme alemán al conflicto italo-etíope (1935-1936)». La cita proviene de las pp. 164 y 200.

124 Cfr. de nuevo Jankélévitch, L'Ironie, cit., p. 9: «el risueño, muy a menudo, se apresura a reír para no tener que llorar». 
proviene de los años cuarenta y cincuenta, de la alianza entre cine y literatura, drama y comedia, presente en otros títulos suyos como Años difíciles y Años fáciles, con guiones de Brancati, con sus viejos, sus cuevas, sus moscas, que acabarán transformándose — tras un lustro de (relativo) boom (cómico) - en Los años inquietos de Salvatore Nocita, película documental emitida por la RAI el 13 de julio de 1967.

La Historia con mayúscula parece amplificar la frase ocurrente más que la comedia, forzando esta en el final — siempre dentro de un código conocido, compartido- y haciéndola extraña a sí misma. En este sentido muchas comedias a la italiana nacidas en torno a la Historia, entre los ańos cincuenta y sesenta, durante el periodo comprendido entre la primera y la segunda guerra mundiales, no son comedias en sentido propio o no lo son por entero. La atención a la concreta realidad social y política de esa época, y de la inmediatamente sucesiva, genera en el cine de Luigi Zampa una oscilación similar a la de Jovine, con una tradición que casi lleva la mano del autor y acaba por acompañar al sufrimiento (el hijo caído en África) una burla amplificada en tanto que originada por nobles miras (la carta ingenua que jamás llegará al Duce y que Manfredi encuentra en su bolsillo por casualidad). No queda, por tanto, sino esperar: el viejo, sin hijo, en su cueva; Miguel, sin brazo, en su pueblo.

La realidad del pueblo sucio y derruido, además, madura más bien dentro de ese estilo, cómico si se quiere aunque sustancialmente trágico: precisamente el de Silone, que todavía se adhiere con fuerza a aquella realidad. Por otro lado, entre un pueblecito de los Abruzos y los alrededores de una pequeña ciudad pullesa no hay diferencia: ambos son símbolos, pueblecito y alrededores, de aquel país herido del que el joven imperio y sus representantes más o menos provinciales no se preocupan en absoluto.

Casi un cuarto de siglo después, pasando de los años de la Guerra de España a los del llamado boom, gracias a aquel «espíritu de ironía» que es "el espíritu de distensión» y que "vuelve ridículo el peligro», ${ }^{125}$ en Italia podemos encontrar al fascismo encerrado en una «jaula». Pero debemos tener en cuenta que la jaula es funcional y peligrosa a un tiempo, porque no libera y deja un tanto «abocetado» al país herido, que es también un

125 Jankélévitch, L'Ironie, cit., pp. 10 y 9. 
pequeño mundo (o un mundo en pequeño) más sufrido: ese microcosmos del que vuelven a salir durante la segunda posguerra jóvenes y menos jóvenes — desde Calvino a Visconti. ${ }^{126}$

Claro que, en la más tardía ficción cinematográfica de Luigi Zampa, queda al menos la consolatoria posibilidad de cantar a coro - casi un himno, carente ya de juventud y belleza inverosímiles - y en voz alta: "Qué asco, qué asco, todo lleno de inmundicia».

Leonardo Sciascia, pues, se nos presenta como una línea divisoria, un límite literario "puro», incluso a nivel estilístico, contra la urgencia de la historia y de la crónica, y contra la transfiguración, que en ocasiones despista (aunque noblemente), de la comedia a la italiana. Su objetivo es hacer nacer la literatura a partir de la memoria y no dejarla morir, desaparecer en esta, sea positiva o negativa, dependiendo del punto de vista. Por ello, la enseńanza del narrador siciliano puede sostener nuestro discurso y enderezarlo por los vericuetos de la memoria literaria italiana relativa a la Guerra de España. Vericuetos, marañas de un episodio histórico y literario que no es que no exista, sino que está disperso en arroyuelos de tradiciones más o menos diferentes, de mayor o menor importancia.

Aunque podríamos hablar, en cierto modo, de una guerra (y una tradición) realmente «inexistente», rescatando quizá Il cavaliere inesistente (El caballero inexistente) (1959) de Calvino, el mismo autor que propuso a Sciascia publicar El antimonio "tal como era». ${ }^{127}$ Podríamos pensar en la Guerra de España como en una armadura que cada uno rellena con lo que le es más afín, como parecen hacer, a fin de cuentas, Orwell, Malraux y Hemingway y como hace, cambiando de dirección, el mismo Sciascia, quien, quizá dejándose convencer por Calvino, no reelabora El antimonio en la gran novela sobre la guerra civil española del siglo XX italiano.

126 Me refiero a Giovannino Guareschi, Mondo piccolo. Don Camillo, Rizzoli, Milán, 1948 (Don Camilo, un mundo pequeño, Homo Legens, Madrid, 2007) y, antes aún, a Piccolo mondo antico (Pequeño mundo antiguo, trad. María Teresa Mayol, Bruguera, Barcelona, 1986) y Piccolo mondo moderno (Pequeño mundo moderno, Lauro, Barcelona, 1943), de Fogazzaro. También a Italo Calvino, Il sentiero dei nidi di ragno, Einaudi, Turín, 1964 (1947) (El sendero de los nidos de araña, trad. Aurora Bernárdez, Tusquets, Barcelona, 1998), con un importante prólogo del autor, así como a la película La tierra tiembla (1948), de Luchino Visconti, que es de la misma generación que el padre de Don Camilo.

127 Ambroise, Invito alla lettura di Sciascia, cit., p. 95. 
Precisamente en relación con la guerra «inexistente», o sea, con el riesgo de una guerra entendida como armadura vacía, como envoltura, es más fácil pensar que Leonardo Sciascia, consciente de ello a partir de sus amados Malraux, Orwell y Hemingway, no quisiera asumir a fondo ese acto extremo de individualismo que habían encarnado fuertes experiencias autorales como las citadas, en obras escritas en la época de la guerra, llegando a caer en la retórica y quizá, en parte, en la traición de la cita ética - cita ética del lenguaje- que ofrecía España y la guerra civil. Sciascia, que disculpaba a Hemingway y los demás autores con serenidad de juicio, en virtud de su participación en los acontecimientos, como hemos visto, quizá no se habría perdonado a sí mismo correr, inadvertidamente, el mismo riesgo.

España ofreció [...] una gran "cita ética» [...], y en ella cada uno acabó buscando, llevando, encontrando lo que le era más afín: los fantasmas de la muerte de personajes agonizantes, la regeneración de la cultura, la visión cuasi religiosa del futuro de la humanidad... No fue tanto la adhesión incondicional a una causa, cuanto un acto extremo de individualismo, una búsqueda de confirmaciones, mediante la acción, de las propias concepciones sociales y artísticas. $^{128}$

Una búsqueda de confirmaciones que para Sciascia, a veinte años de la guerra, no puede verificarse en la acción, ni traducirse solo y enteramente en un dato metaliterario o, como mucho, en un juego, porque «ha habido una guerra». La distancia temporal, pues, impone unos límites, en los términos arriba sugeridos, a la biografía antimoniesca de Leonardo Sciascia, así como a la que habría podido ser la gran novela sobre la Guerra de Espańa del siglo XX italiano.

Por otro lado, al siglo XX italiano en su conjunto le cuesta saldar cuentas con un conflicto que debía parecer lejano ya en 1945 y, con mayor razón, en los años siguientes, porque la Segunda Guerra Mundial y la resistencia informan muchas obras narrativas y contribuyen a que se pierdan las huellas de la lucha española. Pero los partisanos de Elio Bartolini, por ejemplo, la recuerdan todavía, si bien con cierta distancia irónica, como en parte hemos apuntado: «Era su misma observación la que

128 Cfr. Maffi, pról. a Orwell, Omaggio alla Catalogna, cit., p. 255, que para la «cita ética» remite a Romolo Runcini, Illusione e paura nel mondo borghese da Dickens a Orwell, Laterza, Bari, 1968, p. 332. 
le hacía volver atrás [...], a la tarde en que le habían ordenado acudir al puesto de mando, con su comisario; había una mujer a la cabecera de la mesa, la mujer más fea que había visto en su vida. "¿Y esta quién es? ¿Nuestra Pasionaria?” [...] pero arriba, en el puesto de mando, habían decidido hacer de aquellas montańas y de aquel recodo del Tagliamento un nuevo Madrid; la Pasionaria lo decía precisamente así: "un nuevo Madrid"». ${ }^{129}$

En fin, conforme nos vamos alejando de 1945, año harto simbólico por las personas y los sucesos implicados, la guerra civil espańola aparece como una suerte de fantasma, evocado raramente en narraciones que se mueven más allá de la especifidad de un conflicto particular o que incluso tienen un parentesco relativo, general, con el tema de la guerra.

Podemos verificarlo echando un vistazo a la segunda mitad de los años cuarenta y ascendiendo — sin olvidar cuanto se decía en el primer capítulo a propósito de Vittorini y Brancati, sobre quienes de todos modos volveremos- desde 1945, fecha de El imperio en provincias, hasta 1947 y 1949. Podemos pensar en Cesare Pavese y en el pobre Scarpa, «un humilde héroe de la Guerra de España», que encontramos en El camarada, escrito en 1946 "paralelamente a los Dialoghi con Leucò (Diálogos con Leucó)», pero con cuya publicación para Pavese «se abre 1947», ${ }^{130}$ año en que comienza la campaña represiva de McCarthy, la doctrina Truman y el compromiso norteamericano con los países amenazados por el comunismo, al tiempo que se constituye el Kominform, la oficina de información de los partidos comunistas. (También es el año de La peste, de Camus, y Lettere dal carcere [Cartas desde la cárcel], de Gramsci).

En la novela de Pavese emergen, aparte de Scarpa y a pesar de los "aburridos e ineficaces diálogos», ${ }^{131}$ fragmentos significativos en relación precisamente con la guerra civil española y con «una educación política» que se da no por transmisión generacional, de padres a hijos o de viejos a jóvenes, sino "por duras y brutales lecciones tomadas directamente de las cosas y dentro de las cosas, mediante lentas maduraciones individuales,

129 Cfr. una vez más Bartolini, Il Ghebo, cit., pp. 26-27 y 48.

130 Gianni Venturi, Cesare Pavese, col. Il Castoro, La Nuova Italia, Florencia, 1975, pp. 93 y 91.

131 Ib., p. 93. 
fatigosos descubrimientos de la verdad, toda una autoeducación», ${ }^{132} \mathrm{y}$ también en relación con esa «historia [que] continúa moviéndose a empujones no totalmente controlados, a golpe de convicciones parciales y nada claras». ${ }^{133}$ Leamos, por ejemplo, algunos pasajes del capítulo XIV, con los diálogos de Pablo, Luciano, Carletto y Solino:

También en Rusia, decía, pasaba como en Italia. "Mira España — me dijo-, son los rojos quienes hacen todo lo que pueden para perder la guerra». "Cuando se pierde, todos tienen la culpa», salté.

«:Has estado tú en España? Pero en Rusia han ganado, ¿`sí o no?»

Él decía que en Rusia se estaba como en una cárcel. "Alguno tiene que estar en la cárcel», le dije. "Pero que mande quien trabaja ya es una gran cosa». «No manda quien trabaja», dijo él.

[...] Yo estaba atento a los clientes de la tienda y trataba de hacerles hablar. Cuando entraba alguno interesante, echaba mano al periódico. «¿Cómo va esta Guerra de España?», le decía. Pero Solino era el único que me daba respuesta. Él iba y venía de la taberna a la calle, masticaba su colilla, se paraba a escupir. "Habrá trabajo, una vez acabe la guerra», decía. «Echan abajo tantas casas». Pero los más jóvenes, la gente del puente, apenas escuchaban. No había ni uno solo que mirase el periódico. Cáspita, pensaba, o me estoy volviendo viejo o es que soy tonto. También yo he sido como ellos, y solo leía los deportes. ${ }^{134}$

Fragmentos, decíamos. Fragmentos significativos de lo que el mismo Pavese llama «hechos paralelos: guerra de 1915-1918, guerra de España, guerra de Libia». Así los nombra el 17 de noviembre de 1949, en El oficio de vivir, tras haber constatado, al final de La luna e i Faló (La luna y las hogueras), la conclusión del "ciclo histórico de [su] tiempo» y de una «saga completa», con los episodios fuertes del «antifascismo embrionario», el "antifascismo clandestino», la «resistencia» y la «post-resistencia», y con «dos jóvenes (La cárcel, El camarada) y dos cuarentones (La casa en la coli-

132 Vittorini, Diario in pubblico, cit., pp. 212-213.

133 Calvino, «Sono stato stalinista anch'io?», cit., p. 199.

134 Cesare Pavese, Il compagno, Einaudi, Turín, 1947; reed. Mondadori, col. Oscar, Milán, 1981, pp. 152-153 (De tu tierra; El camarada, trad. Esther Benítez, Bruguera, Barcelona, 1982). La frase final, a propósito del deporte, podría además contrastarse con un dato histórico que, dejando a un lado el tópico, merece quizá la pena anotar: el hecho de que Italia ganara los dos mundiales de fútbol — prácticamente el deporte por antonomasia en Italia, junto al ciclismo, en aquella época; hoy el único en absoluto- anteriores a la guerra, en 1934 y en 1938. Mussolini no pierde ocasión para favorecer, incluso ilícitamente, tales victorias y hacer así propaganda, dando en la diana al menos con "los más jóvenes», quizá también con el objetivo de hacer olvidar las arenas movedizas españolas, que en el verano de 1938, con la ofensiva republicana en el Ebro, todavía lo parecen. 
na, La luna y las hogueras); dos campesinos (El camarada, La luna y las hogueras) y dos intelectuales (La cárcel, La casa en la colina)». ${ }^{135}$

Pero, volviendo a subir la tortuosa pendiente de la segunda mitad de los ańos cuarenta y retornando al sur, recordemos a Vitaliano Brancati, otro siciliano muy amado por Sciascia, ya citado en el capítulo primero a propósito de dos relatos de 1944, Il vecchio con gli stivali (El viejo con botas) y La noia nel '937 (El tedio del '937). Piénsese ahora en el tío Hermenegildo de El guapo Antonio, de 1949, que vuelve del infierno español y vive presa de una «enfermedad de los nervios», entre una toma de conciencia inicial, que a nuestros oídos suena un tanto koestleriana, y numerosos sueńos de muerte, en parte similares a los del voluntario sciasciano (por ejemplo, en el significativo contraste fiesta-funeral):

Tío y sobrino se quedaron a solas [...]. «El mundo es horrible!», dijo Hermenegildo [...]. «iMás que horrible!...». Pero se interrumpió porque el otro seguía con los ojos cerrados.

"No estoy dormido", dijo Antonio sin abrir los ojos. «Al contrario, te escucho con placer. ¡Cuéntame dónde has estado!».

"¿Que dónde he estado? ¡Eh! ¡He estado donde nunca debería haber estado! He estado en Espańa, enhoramala, y he aprendido quiénes son mis contemporáneos y los hombres en general... Son espantosos, Antonio mío, y por lo bien que quieres a tu madre, créeme, ¡me dan miedo!

Esperó a que el sobrino abriera los ojos, pero como no lo hacía, volvió a encender la pipa, que se había apagado, y continuó: «iNo me preguntes quién tiene razón y quién se equivoca, o cuál de los dos principios triunfará un día! Las ideas se las guardan en su cabeza y yo no las he visto. Lo que sí he visto es que están dispuestos a degollar, a descuartizar y a quemar hasta a Jesucristo en persona, tanto de un lado como del otro, y si caes bajo su odio, iprepárate a lanzar un grito de dolor como jamás habrías pensado que pudiera salir de tus tripas de criatura bautizada!». sentarse.

Fue hacia el balcón, abrió sus puertas, escupió fuera, las cerró y volvió a

«iTú no puedes imaginar qué clase de sufrimientos son capaces de aplicar en tu carne! ¡Les basta un centímetro de tu piel para meterte dentro todo el infierno! ¡No hay coraje que valga, hijo mío! ¡Yo no soy ningún cobarde, pero te aseguro que no hay coraje que valga! La civilización cristiana y la justicia social: ¡hermosas palabras! Tanto una como otra son un bien precioso de los hombres. ¡Pero mira luego las muecas de los cadáveres que dejan pudrirse durante días enteros en los charcos, y sobre cuyos rostros hacen pasar los camiones para borrarles cualquier fisonomía, y dime si es así como se prepara

135 Cesare Pavese, Il mestiere di vivere. 1935-1950, Einaudi, Turín, 1952; reed. Marziano Guglielminetti y Laura Nay, 1990, p. 375 (El oficio de vivir, trad. Ángel Crespo, Seix Barral, Barcelona, 2001). 
el bien de los hombres! ¡También eran hombres esos cadáveres, por Dios, y mira de qué modo se lo han regalado! Me dirás que todo esto se hace por los hombres del mañana... ¡Pero también los hombres del mañana pensarán en el futuro, también ellos querrán hacer algo por los que les sucederán, y se despedazarán unos a otros como nuestros contemporáneos! ¡Este tipo de bien jamás tiene fin! ¡No, Antonio, créeme, los hombres dan terror y yo los veo en mis pesadillas!

"iLo que has conseguido es enfermarte de los nervios!», dijo Antonio con dulzura. «Deberías tomar somníferos para no tener pesadillas por la noche!» «iLlámalo como quieras! Enfermedad de los nervios... Pero en cuanto a dormir sin pesadillas, ya no soy capaz, ni siquiera rozando el suicidio con veronal. Mi cerebro ya no logra ajustar bien, como una vieja puerta desvencijada que deja pasar mil hilos de luz... ¡Y si solo fuese la luz!... Pero están los ruidos, la algarabía, las voces... ¿Por qué quise mirarles a la cara a aquellos seres infames? Por dios, ¿quién me mandó hacerlo? ¡Quería entender quién de ellos tenía razón y quién se equivocaba, y lo único que he entendido es que son todos igual de horribles! ¡Buena ganancia he hecho con este viaje al extranjero! ¡Buena ganancia! ¡Que aproveche! ¡Felicidades! Por suerte mi corazón se ha agrandado, mis pulmones se han comprimido, y todo hace presagiar que el próximo año los petardos de la fiesta de Santa Ágata los oiréis sin mí».

«Pero tío, ¿qué dices? ¡Seguro que serás tú quien nos lleve a todos al cementerio!», murmuró Antonio, todavía con los ojos cerrados.

« No, no me quites este único consuelo! Para dormirme, por la noche, tengo que pensar que la muerte se sienta a mi cabecera. Es el único pensamiento que me da un poco de paz. Fuera de esto solo encuentro agitación, terror, insomnio y sudores fríos. No, Antonio; es así. Por suerte para mí, dentro de pocos meses las revoluciones ya no podrán hacerme nada, y tampoco las reacciones. Fascismo, comunismo... me dejan ahora tranquilo. Venza uno u otro, ninguno de estos prepotentes logrará ya hacerme nada, quitándome el pan o el aire. Ninguno logrará jamás arrancarme de las vísceras aquel grito que he intentado imitar tantas veces, completamente solo ante el espejo de casa, para confortarme con el pensamiento de que entra dentro de las capacidades humanas chillar así. Lo he intentado, sí, pero siempre inútilmente: ¡por eso he calibrado lo bestial que debe de ser un sufrimiento que lo enseña así, de golpe, a un ser humano!».

Antonio abrió entonces los ojos, tiernamente enamorado de aquel hombre dulcificado por el deseo de morir. ${ }^{136}$

El discurso «nervioso» del tío Hermenegildo, todo arrebatos y exclamaciones — recordemos a Aldo Piscitello con su mujer-, es una mímesis, estilísticamente ejemplar, de la locura del siglo XX — a partir del dato de la Guerra de España- puesta en escena y denunciada en un monólo-

136 Se cita por el capítulo viII de Brancati, Il bell'Antonio, Bompiani, Milán, 1949; reed. en col. Oscar Classici Moderni, Mondadori, nota de Leonardo Sciascia, Milán, 2001, pp. 135-138 (El guapo Antonio, trad. Rosa Marcela Pericás, Planeta, Barcelona, 1973). 
go al que asiste el sobrino Antonio, con los ojos cerrados (que traen a la memoria la novela homónima de Federigo Tozzi), encarnando en todo momento el otro polo del modus vivendi brancatiano, es decir, como sugiere Giulio Ferroni, la «sensual utopía de la pasividad, del no hacer nada, de la vida que transcurre gratuita». ${ }^{137} \mathrm{Al}$ final del largo, espléndido pasaje, el sobrino abre los ojos y los dos polos se tocan, se identifican en el «deseo de morir» que dulcifica la representación y la denuncia de la locura del siglo, haciendo que el joven se «enamore» del viejo, escapando otra vez, a fin de cuentas, a la transmisión generacional — pues es la brutal, bestial, directa lección del sufrimiento la que enseña a gritar «así, de golpe, a un ser humano" - y al dato de la guerra civil; dato asumido luego, junto a los demás, en la parábola de la impotencia de Antonio, que es también, si se quiere, una alternativa pasiva e iluminista a las "fantasías viriles»" ${ }^{138}$ de la guerra, del guerrero fascista o del guerrero, sin más, de un lado y del otro.

Si nos retrotraemos de la segunda mitad de los años cuarenta, con Jovine, Pavese y Brancati, a la segunda mitad de los años treinta, ${ }^{139}$ con el

137 Ferroni, "Vitaliano Brancati e le illusioni di un secolo "superbo e sciocco"», cit., p. 141.

138 Cfr. Klaus Theweleit, Fantasie virili, Il Saggiatore, Milán, 1997 (1977). También, por problemáticas y discutibles contigüidades, cfr. Lorenzo Benadussi, Il nemico dell'uomo nuovo. L'omosessualità nell'esperimento totalitario fascista, Feltrinelli, Milán, 2005; así como Gianfranco Goretti y Tommaso Giartosio, La città e l'isola. Omosessuali al confino nell'Italia fascista, Donzelli, Roma, 2006.

139 Primero son las "páginas de vagabundeo» de Carlo Linati, que todavía representa otra generación (1878-1949) y, en general, otra recepción o, mejor, una recepción (no solo italiana) que está transformándose entre la segunda mitad de los años veinte — la moda de una España genuina, profunda, romántica y pintoresca está en su apogeo, por ejemplo en la «interpretación lírica de Waldo Frank», Virgin Spain (1926) — y la primera mitad de los años treinta, en que la historia más reciente se insinúa incluso en los trabajos más ingenuos y librescos: véase al menos el prólogo (y los textos siguientes) de Élise Champagne, Randonnée Espagnole, Les Éditions de Belgique, Bruselas, 1937, p. 5: «Este viaje data de 1934, unos días antes de los primeros conflictos, signos precursores de la tragedia actual. Barcelona estaba ya en estado de sitio, pero el interior del país yacía en calma, si no feliz. [...]. A menudo teníamos el alma encogida releyendo los apuntes líricos de nuestro diario, mientras los comunicados de la guerra civil nos traían noticias que hacían llorar». Confróntese con Carlo Linati, "Un po' di vecchia Spagna (1934), en A vento e sole. Pagine di vagabondaggio, Società Subalpina Editrice, Turín, 1939; y reed. Biblioteca del Vascello, Roma, 1992, pp. 11-27; en particular, pp. 12-15, aquella "Velada madrileńa» que se abre narrativamente «a primeros de septiembre del 34» con «la huelga general en Madrid» y prosigue 
conflicto en curso, es difícil encontrar tanto potenciales orígenes como eventuales correspondencias a las oscilaciones de Jovine, los fragmentos de Pavese y el monólogo de Brancati. Estos textos, por otro lado, pueden nutrir una tradición narrativa italiana sobre la guerra civil española, pero sin darle una cumplida identidad e incluso relegando el episodio a "hecho lateral», más allá de Pavese y de acuerdo con otros datos históricos — también histórico-geográficos, histórico-culturales- que asumen en Italia

con anotaciones como estas: «España atravesaba aquellos días horas de amedrentada quietud: comenzaban a delinearse por todos sus flancos esos síntomas febriles que después estallarían en las sangrientas sublevaciones de octubre. Paseando por sus ciudades se tenía ya, desde aquel momento, la sensación del desorden que se abría paso. [...] Barcelona [...] Madrid [...] El aire estaba cargado de electricidad y como de una trágica sensación de emboscada»; "iLo malo es que no hay tierra como España, donde las palabras y los gestos sean capaces de producir más sangre!» (pp. 12-13). Aquí los títulos ligeros y anclados al pasado empiezan a darse de puńetazos con la materia que agita la península pentagonal, podríamos decir con Mario Praz, autor de un libro que revisa, ya en la segunda mitad de los años veinte, la vieja, romántica España. Pienso, precisamente, en su Penisola pentagonale, Alpes, Milán, 1928 - la versión inglesa lo titula Unromantic Spain, Knopf, LondresNueva York, 1929_; reeditada hoy, con pról. de Goffredo Fofi y «advertencia» (1954) del autor, por E. D. T., Turín, 1992 (Península pentagonal: la España antirromántica, trad. Manuel Vicente Rodríguez, Almuzara, Córdoba, 2007) En cualquier caso, Praz todavía rinde tributo a lo pintoresco — quizá porque ciertos episodios, muy influyentes para la imagen del país, están por llegar, no obstante el exotismo, primero, y luego la retórica de los vencidos y el conservadurismo dictatorial aseguren supervivencias significativas, como he tratado de poner en evidencia en la primera parte de este capítulo_-, según lo que honestamente sugiere la propia «advertencia», p. 15: «Habiendo partido con el propósito de desmontar la leyenda de lo español pintoresco, hoy mi libro me parece un libro pintoresco [...] Península pentagonal les parece hoy a muchos digno de ser exhumado, aunque España ha debido de cambiar mucho desde 1926 [año de la peregrinación praziana]». En la segunda mitad de los años treinta, «los primeros conflictos» de Élise Champagne y los «síntomas febriles» de Carlo Linati, ya trágicamente desarrollados, deberían ser objeto de preguntas, pero en cambio se trata de ignorarlos en la aparente calma que precede al estallido, volviendo al pasado, la cultura, el folclore españoles; si bien luego se deslizan en los textos episodios que delatan tomas de postura fácilmente descifrables, "parciales». Desde esta perspectiva, entre los escritos de viaje por España más escorados — facciosamente escorados- que registran el desorden, véase un reportaje que tiene ya ante los ojos la guerra civil pero que, al menos en apariencia, no quiere hablar de ella, salvo para evocarla luego como «una epopeya atormentada y gloriosa» que parece encontrar su origen solo en el asesinato de Calvo Sotelo, líder de la derecha monárquica, y de la cual, en el desarrollo del texto, aparecen solo como responsables Azaña y Largo Caballero (lo son, en todo caso, como primeros gobernantes de la República, de un bienio «a la jacobina» entre abril de 1931 y abril de 1933, y, en otro sentido, de la «revolución de octubre» de 1934 y algunas de sus consecuencias, aun dentro de la guerra civil): Mario Puccini, Amore di Spagna. Taccuino di viaggio, Ceschina, Milán, 1938. Con éxplicit de junio de 1936 y publicado, parece, a finales de 1937, Puccini — otro autor olvidado, casi de la misma generación de Lina- 
mayor peso en el paso de una década a otra: el sur, la provincia, para Jovine; el antifascismo embrionario y clandestino, la resistencia y la posresistencia, para Pavese; el iluminismo (y una sensual utopía de la pasividad), para Brancati, dentro de una trayectoria que va de Beccaria y Manzoni a Vittorini y Sciascia (que contiene más rebelión y menos no hacer nada). ${ }^{140}$

Pero en la segunda mitad de los años treinta los potenciales orígenes y las eventuales correspondencias de los textos apenas evocados deben medirse con la censura, pues nos encontramos en plena dictadura, en pleno «consenso». Mayor significado asume, entonces, el hecho de que ciertos datos histórico-geográficos, ciertas constantes culturales como el

ti (1887-1957) — lo redactó a partir de un viaje realizado en tres momentos, el último de los cuales, a la altura de mayo-junio de 1936, al calor de los trágicos sucesos españoles, de los que ya dan cuenta las rápidas páginas introductorias, escritas más tarde: «¿De nuevo un libro sobre España? No querría que se me malentendiera; la España de la guerra civil, la España que todas las mañanas, más o menos brevemente, más o menos intensamente, nos relata los momentos y los pasajes de su trágico padecimiento, no está en este libro. Cercano como he estado desde hace más de veinte años a la historia, al espíritu, al arte, a los hombres de este país, he querido más bien remontar el curso de mis encuentros, de mis experiencias, de mis contactos: ¿qué era ayer Espańa y por qué hoy sufre su epopeya atormentada y gloriosa? [...] Tres veces he estado en España, la última precisamente en vísperas de la guerra civil: estaba en Madrid en mayo del 36; en Barcelona, Bilbao y San Sebastián, en las primeras semanas de junio. Y ese año, poco antes de que se consumase el asesinato de Calvo Sotelo, no vi únicamente ciudades, pueblos y villas; también he visto y me he acercado a políticos y a escritores, a hombres del pueblo y de la burguesía. [...]. Pero yo siempre traté de leer más allá de los actos y de las palabras; me lo permitía el conocimiento de la literatura del ayer, el conocimiento y la familiaridad con la literatura actual. Porque parece imposible, pero la historia de un pueblo casi siempre está fermentada y modelada por su literatura» (pp. 7-9). Sobre Azańa y Largo Caballero léanse además las pp. 150-155 y 156-160. Para el aflorar de la guerra y su inmediato contexto político, ideológico, cultural (más que literario sin más), dentro de un texto que, repetimos, querría no hablar de ella, cfr. las pp. 19-20, 27-29, 40-49, 76-79, casi todo el capítulo sobre Madrid, pp. 101-189, y, una vez más, las pp. 196-200, 220-228, 242-247, 289-295, 304-308, $317-$ 322, 330-335, 343-347, 357-367 y 368-373. Para Puccini, cfr. también Roberto Pirani, Bibliografía di Mario Puccini, colaboraciones de Monica Mare y Maria Grazia De Antoni, Fondazione Rosellini per la Letteratura Popolare, Senigallia-Ostra Vetere (Ancona), 2002. Para Azaña, Largo Caballero, su gobierno «a la jacobina», 1934, su estela, así como para el asesinato de Calvo Sotelo — casi un "Matteotti" de la derecha española- que "en cualquier caso, es solo el acelerador de una respuesta reaccionaria que se gestaba desde hacía tiempo", cfr. una vez más Ranzato, L'eclissi della democrazia. La guerra civile spagnola e le sue origini. 1931-1939, cit., pp. XII-XV, XVII-XVIII, 115-150, 209-249 y 264-268 (cita de la p. 265).

140 Cfr. una vez más los ensayos de Ferroni, «Vitaliano Brancati e le illusioni di un secolo "superbo e sciocco", cit., así como de Ambroise, "Sciascia e la rivolta», cit. 
sur (esa provincia que también está en el norte) y el iluminismo (con esa utopía de la pasividad que sensualmente le acompaña, hasta en tierras septentrionales), vuelvan a caracterizar oscilaciones, fragmentos y monólogos (más o menos interrumpidos o de otro signo) de otra tríada de narradores igualmente ejemplar: Elio Vittorini, Antonio Delfini, Alba De Céspedes.

En cuanto a oscilaciones, no fáciles de interpretar pero siempre dramáticas, sobre la Guerra de Espańa, Elio Vittorini introduce un dato ridículo dentro de un falso reportaje de agosto de 1936, firmado por El Gringo. En efecto, antes de los «abstractos furores» que abren Conversación en Sicilia, iniciada en 1937 y publicada en Letteratura en 1938 y 1939, El Gringo-Elio Vittorini envió a otra revista, Il Bargello, en el verano de 1936, un fragmento que no fue publicado y saldrá solo en 1985, gracias a Giovanni Falaschi. ${ }^{141}$

El artículo, «En Málaga la tienen tomada con Inglaterra», de más concretos "furores», se cierra con una "charla» de café casi a la manera de Hemingway y tiene un arranque narrativo apenas traicionado, digamos, por las coordenadas del falso reportaje: «España, agosto. Avanzada la tarde, casi al crepúsculo, llegamos a Málaga [...]. Pasamos a sotavento de un brazo de ciudad. Había torres de fábricas, altas fachadas de casas populares, y en cada ventana se agitaba una bandera roja, alguna tricolor de la república aquí y allá». ${ }^{142}$

Ciertamente, no es un fragmento fácil de descifrar. Desde sus primeras frases simpatiza con el pueblo, con la multitud, con los republicanos,

141 Cfr. el apéndice "La rivoluzione spagnola. A Malaga ce l'hanno con l'Inghilterra», en Elio Vittorini, Conversazione in Sicilia, ilustraciones de Renato Guttuso, introd. y notas de Giovanni Falaschi, nota de Sergio Pautasso, Rizzoli, Milán, 1986 (reed. col. BUR, 1988, pp. 345-353, que comprenden una «Nota al texto» [pp. 345-348] donde Falaschi ofrece las noticias concernientes a la publicación) (Conversación en Sicilia, trad. Carlos Manzano, Gadir, Madrid, 2004). Cfr. «Elio Vittorini: lettere al Bargello (con un inedito sulla guerra di Spagna)», Inventario, 13, 1985 (inédito reproducido luego por Pautasso en el Corriere della Sera, 12 de febrero de 1986). Pero cfr. también Giorgio Luti, Le parole e il tempo. Paragrafi di storia letteraria del Novecento, Valecchi, Florencia, 1987, pp. 104-110, que remite a las cartas y al inédito recogidos por Falaschi, así como a los trabajos de Anna Panicali, Il primo Vittorini, Celuc, Milán, 1974, e Il romanzo del lavoro, Milella, Lecce, 1982. Véase también Alba Andreini, La ragione letteraria. Saggio sul giovane Vittorini, Nistri-Lischi, Pisa, 1979.

142 Cfr. El Gringo, «La rivoluzione spagnola», cit., p. 349. 
no obstante aspire también a atrapar a los lectores fascistas italianos citando a Azańa y otros políticos burgueses: «Y los nombres que se elevaban de la multitud, gritados con entusiasmo, no eran los de los cabecillas comunistas o anarquistas, sino los de los burgueses, Azaña, Giral [...]». ${ }^{143}$

Pero, inmediatamente después, Vittorini acaba por comprender y apreciar la "retórica» de los «defensores rojos» en la inmediatez de la revolución y de la guerra, anticipando incluso una visión casi sciasciana:

Morir en libertad. Será retórica, pero una retórica que pasa por el heroísmo o, al menos, por la desesperación, por el ensańamiento. En Badajoz los defensores rojos de la ciudad prefirieron la fusilación en masa antes que refugiarse en territorio portugués. La fusilación en masa era «morir por la libertad", y refugiarse en territorio portugués, humillarse ante los "hijos de cura». Así, cuando se cede, no es jamás por debilidad de las milicias obreras, sino por culpa de los guardias civiles, de los guardias de asalto y, en fin, de los militares de oficio, a quienes no les importa nada eso de "morir en libertad». ${ }^{144}$

Estamos casi en las inmediaciones de Sciascia, veinte años después, a la altura de La sexta jornada (1958), o bien del vittoriniano Diario in pubblico (Diario público) (1957). El artículo de Elio-El Gringo se dispone a despedirse en dos tiempos, rindiendo un significativo tributo a la crónica — mediante el diálogo, claro, la «charla» - y ridiculizando a uno de los generales rebeldes, Gonzalo Queipo de Llano, famoso por sus «baladronadas» nocturnas en la radio, que muestran ya su vulgaridad, ya su arrogancia política cuando carga, por ejemplo, contra las familias de los marineros rojos, destinadas a probar la virilidad de los legionarios, y contra Inglaterra, que, como dice sonriendo un soldado republicano, pagó «la marcha sobre Lisboa... y ahora paga la marcha sobre Madrid», porque "quiere las Baleares»: "Nos enseñan que es Italia, o Alemania [...], pero nosotros sabemos que es Inglaterra la que ha fomentado la rebelión y pagado a Franco». ${ }^{145}$

Y aquí, Elio Vittorini, difuminando en los dos breves párrafos finales las «revelaciones» del soldado, cuela de rondón un punto fuerte de la polí-

143 Ib., p. 350.

144 Ib., p. 351. Cfr. una carta de Vittorini a Silvio Guarnieri, del 25 de julio de 1936, en Elio Vittorini, I libri, la città, il mondo. Lettere 1933-1943, ed. Carlo Minoia, Einaudi, Turín, 1985, p. 58: «¿Cómo no se va a sentir entusiasmo por estos obreros que salen de sus talleres a defender su esperanza?» (en cursiva en el original).

145 El Gringo, «La rivoluzione spagnola», cit., p. 352. 
tica de Mussolini en España, las Baleares justamente, y sobre todo la propaganda antibritánica del fascismo italiano de mediados de los ańos treinta, como se desprende, por ejemplo, del libelo Cómo Inglaterra se adueñó del mundo (1936, el mismo año del reportaje del Gringo), de Antonio G. Quattrini y Nino Verestin. ${ }^{146}$

Leamos, pues, el final del fragmento de Vittorini:

«Sería curioso que fuese así de verdad», exclamamos. «Entonces, ¿cómo es que en la radio de Sevilla el general Queipo de Llano carga contra Inglaterra de vez en cuando?

«iOh, Queipo de Llano! Es la bebida, que se le sube a la cabeza. Por lo demás, cada vez que carga contra Inglaterra, Franco sale de Tetuán en avión hacia Sevilla y, a la mañana siguiente, Queipo se traga todo lo que ha escupido» (El Gringo). ${ }^{147}$

A menos que nos confiemos a esta correspondencia imaginaria de Vittorini-El Gringo desde el frente español, en agosto de 1936, o a una más tardía ilustración de Renato Guttuso, que representa un periódico fascista rasgado, tirado por el suelo, con titulares que aplauden la «justa» masacre de Guernica, y que se remonta a 1943 aunque fue insertada solo años después, junto con otras, en Conversación en Sicilia (artículo e imagen adornan, no por casualidad, las más recientes ediciones de la novela), los «abstractos furores» parecen no ir más allá del «típico afirmar por epigramas» vittoriniano. Garosci, a propósito siempre de la Guerra de España, advierte ese estilo epigramático incluso veinte años después —con excesivo rigor- ${ }^{148}$ en Diario público, de 1957. Diario que ahora no ponemos solo al servicio de un discurso vittoriniano y/o

146 Hojéese al menos el índice, p. 207, de Antonio G. Quattrini y Nino Verestin, Come l'Inghilterra s'impadronì del mondo, AEQUA (Anonima Edizione Quattrini), Roma, 1936, con los seis capítulos dedicados a "Matices de la historia de Inglaterra", "El primer plato: América», «El segundo plato: las Indias», «El tercer plato: Australia, desierto inglés», «El cuarto plato: África» y "Un plato... saltado: Etiopía», en pp. 189-205, con un exergo tomado de Vincenzo Monti, All'Inghilterra, «fragua de delitos», y una línea de conclusión seguida por un Nota bene: "Un mundo entero está a punto de derrumbarse ante el empuje de las legiones romanas... N. B. Los autores se comprometen formalmente a completar esta última frase en tres meses», p. 205.

147 Cfr. una vez más El Gringo, «La rivoluzione spagnola», cit., pp. 352-353.

148 Garosci, Gli intellettuali e la guerra di Spagna, cit., pp. 454-455. Pero quizá ese «típico afirmar por epigramas» es hijo de la época y escapa a la obra de Elio Vittorini, quien, entre "exhibiciones de inútil ferocidad en las elipsis» $\mathrm{y}$ "la oscuridad de ciertos símbolos», parece abrazar anticipadamente la realidad de su tiempo en Conversación en Sicilia. 
sciasciano, sino que también lo hacemos jugar con los tiempos y los modos de reaccionar de Antonio Delfini ante el conflicto español: por un lado, Conversación en Sicilia (1938-1939) y Diario público (1957); por otro, Il ricordo della Basca (El recuerdo de la Vasca), relato aparecido en la colección homónima de 1938, y Una historia, conjunto de instrucciones de lectura y testimonios "públicos» escritos por Delfini para su segunda edición en 1956.

Pero procedamos con orden y releamos el primer capítulo, intenso, de Conversación en Sicilia, dos páginas secas entre las que se intercala hoy la ilustración de Guttuso:

Era yo, aquel invierno, presa de abstractos furores. No diré cuáles, no me he puesto a escribir para esto. Pero es necesario que diga que eran abstractos, ni heroicos ni vivos; furores, en cualquier caso, por el género humano perdido. Duraba esto desde hacía mucho tiempo, y yo siempre con la cabeza inclinada. Veía anuncios de periódicos estridentes e inclinaba la cabeza; veía amigos durante una hora, dos horas, y permanecía con ellos sin decir una palabra, e inclinaba la cabeza; y tenía una novia o esposa que me esperaba, pero tampoco con ella cambiaba una sola palabra, también con ella inclinaba la cabeza. Entre

Pienso una vez más en Fortini, "Guerra a Milano» (1943), en Sere in Valdossola, cit., pp. 35-36 y 80-83: "Jueves 29 [julio de 1943]. Milán ha vivido grandes jornadas de exaltación. Lo veo en las caras de la gente, lo escucho en las conversaciones [...]. Sientes por doquier una inteligencia valiente, como si el aire de la gran ciudad hubiese preservado a esta población de la torpeza del resto de Italia. Las obreritas en delantal negro, los vendedores sentados a la puerta de las tabernas, las mesoneras en el mostrador de las bebidas, todos hablan en estos días con una libertad epigramática que creía solo hubiese existido en el París de los recuerdos literarios»; Jueves 12 [agosto de 1943]. He logrado encontrar a Elio Vittorini. Sé que ha salido de prisión hace pocos días [...]. Me han dicho que es comunista. Y aun cuando sepa que trabaja en el partido y que nada tiene que ver con ciertos comunistas diletantes y sentimentales, pienso, sin embargo, que también para él el comunismo sea la fórmula en la que encerrar la exigencia de resurrección y redención que dona su fuerza al poeta y al escritor. [...]. Jamás podré creer en la verdad de una vez por todas, no sabría renunciar a $m i$ verdad ni a mis errores. Pero sé que Vittorini también es así. Hablamos de su libro, que tan merecido éxito ha tenido en Italia y en el extranjero: Conversación en Sicilia. Libro del que me resulta difícil hablar con él en términos de crítica. Le apunto alguna objeción: exhibiciones de inútil ferocidad en las elipsis; una voluntad demasiado explícita aquí y allá, que fuerza la escritura; la excesiva y caduca facilidad de ciertos efectos, la oscuridad de ciertos símbolos. Desde mi punto de vista es un libro muy importante, aunque incompleto y no bien armonizado. [...]. Esto es lo que sé, y me cuesta expresarlo: en algunas páginas de ese libro se dice fatigosamente y a duras penas algo que para mí es verdadero. Creo que en esto consista toda la recompensa de un autor. No logro comprender qué tenga que ver con el comunismo. Probablemente nada». Quizá, en ciertos aspectos, la mejor aportación «no crítica» sobre Conversación en Sicilia. 
tanto llovía y pasaban los días, los meses, y yo tenía los zapatos rotos, el agua se me metía por los zapatos, y no había nada más que esto: lluvia, masacres en los anuncios de los periódicos, y agua en mis zapatos rotos, amigos mudos, la vida dentro de mí como un sueño sordo, y nada de esperanza, quietud.

Esto era lo terrible: la quietud en la no esperanza. Creer que el género humano estaba perdido y no tener el ansia de hacer algo, solo ganas de perderme, por ejemplo, con él. Estaba agitado por abstractos furores, no de la sangre, y estaba sosegado, no tenía ganas de nada. No me importaba que mi chica me esperase; reunirme con ella o no u hojear un diccionario eran lo mismo para mí; y salir a ver a los amigos, a otras personas, o quedarme en casa eran la misma cosa. Estaba sosegado; era como si no hubiese tenido jamás un día de vida, ni hubiese sabido nunca lo que significaba ser feliz, como si no tuviese nada que decir, que afirmar o negar, nada mío que poner en juego, ni nada que escuchar, nada que dar y ninguna disposición para recibir, y como si jamás en todos mis años de existencia hubiera comido pan, bebido vino, o café, ni estado en la cama con una chica, tenido hijos, dado un puñetazo a alguien, o no creyese que todo esto fuera posible, como si nunca hubiera tenido una infancia en Sicilia en medio de higos chumbos y azufre, en las montańas; pero me agitaba en mi interior por abstractos furores, y pensaba en el género humano perdido, inclinaba la cabeza y llovía, no decía una sola palabra a los amigos y el agua se me metía en los zapatos. ${ }^{149}$

Giaime Pintor saludó la aparición en 1941 —bajo el título de Nome e lagrime (Nombre y lágrimas), breve relato que precede a la novela y un poco la «esconde»— de «ese libro profundamente imperfecto y lleno de terribles abstractismos que es Conversación en Sicilia», apuntando más que otros al citado arranque. Lo hizo en una reseña aparecida en Prospettive, recogida en el volumen póstumo Il sangue d'Europa (1939-1943) (La sangre de Europa) bajo el título «La alegoría del sentimento»: «En ningún libro reciente el dolor o la angustia, el elemento humano en fin, que está en el origen de la creación, se han mostrado tan evidentes y menos oscurecidos por la trama literaria. Por esto Conversación en Sicilia tiene un valor absoluto de alegoría, la única posible, del sentimiento, discurso en que los hombres y las cosas son portadores de signos que nos resultan familiares y, sin embargo, quedan siempre remotos, más allá de los límites de la crónica». ${ }^{150}$

149 Vittorini, Conversazione in Sicilia, cit., pp. 131 y 133 (en la p. 132 está la citada ilustración de Renato Guttuso); pero cfr. también las pp. 249-250 y 309-336, correspondientes a la quinta parte, en que el protagonista «habla» con el hermano muerto en la guerra y luego discute de ello con la madre.

150 Vittorini, Nome e lagrime, Parenti, Florencia, 1941. El libro sale el 1 de marzo de 1941 y la reseña de Pintor está en el número del 15 de abril-15 de mayo de Prospettive, 1617, 1941, y luego, bajo el título «L'allegoria del sentimento», en Giaime Pintor, Il sangue d'Europa (1939-1943), ed. Valentino Gerratana, col. Saggi, Einaudi, Turín, 1950, pp. 155- 
Creo que sigue siendo el mejor modo de leer Conversación en Sicilia, de ir más allá del «típico afirmar por epigramas» del que habla Garosci, así como de apreciar su cualidad de libro imperfecto, pensado para escapar a «los límites de la crónica», empezando por la de El Gringo, que se difumina en un comienzo donde, como subrayaba recientemente Vittorio Spinazzola, «nos corresponde a nosotros deducir que se trata de la Guerra de España». ${ }^{151}$

La alegoría del sentimiento se superpone al ridículo con que se cierra la crónica de los años rugientes del Gringo obrerista, y establece un pacto narrativo y ético con un yo que «aprende de nuevo a conversar». ${ }^{152} \mathrm{La}$ pieza brillante, el falso reportaje, ceden paso a un relato en primera persona - la «infancia en Sicilia en medio de higos chumbos y azufre», la carta del padre, la madre y el hermano Liborio, el soldado muerto- que salva el compromiso y pide la colaboración activa del lector en cuanto a lo «no dicho» y en cuanto a su futuro, dentro y fuera del propio Vittorini. Al menos, hasta ese «lector modelo» que será Sciascia en las generaciones siguientes, quien, como ya hemos señalado, prefirirá precisamente Diario público a Conversación en Sicilia, grado cero de la escritura vittoriniana, del mismo modo que El antimonio lo es para la sciasciana. Ambos textos, por otro lado, son una suerte de viático para una vuelta a los orígenes, desti-

158 (reed. col. NUE Nuova Serie, 1965, 1975 y 1977). Citamos a partir de esta última, p. 97. Entre las primerísimas reseñas de Nombre y lágrimas, atentas al dato de los «abstractos furores», está la de Oreste Macrí, "Letture II», Vedetta Mediterranea, 2, 1941 (31-31941), luego titulada "L"astratto furore" di Elio Vittorini", en Macrí, Caratteri e figure della poesia italiana contemporanea, Vallecchi, Florencia, 1956, pp. 343-348. Actualmente, para una cronología de los abstractos furores y su ubicación en la Guerra de Espańa y en la obra de Vittorini, desde El clavel rojo a Conversación en Sicilia y hasta la llegada de Diario público, cfr. al menos el segundo y tercer capítulo de Raffaella Rodondi, Il presente vince sempre. Tre studi su Vittorini, Sellerio, Palermo, 1985, pp. 164-222 (especialmente el último epígrafe, dedicado a "I barlumi degli "astratti furori”", pp. 211-222) y 223-336. En lo biográfico, en torno al proyecto vittoriniano de ir a España — vía París - con Pratolini, para combatir contra los franquistas, cfr. Raffaele Crovi, Il lungo viaggio di Vittorini. Una biografia critica, Marsilio, Venecia, 1998, pp. 147-151, 156-159, 161 y 167-169, que remite sobre todo a Romano Bilenchi, "Vittorini en Florencia», en Elio Vittorini, n. ${ }^{\circ}$ especial de Il Ponte, 7-8, 1973, pp. 1.085-1.131, y ahora en Bilenchi, Opere, pról. Mario Luzi, eds. Benedetta Centovalli, Massimo Depaoli y Cristina Nesi, Rizzoli, Milán, 1997, pp. 788-831.

151 Vittorio Spinazzola, "Un aquilone sulla Sicilia», en Itaca, addio, Il Saggiatore, Milán, 2001, p. 46.

152 Ib., pp. 46-50. 
nada a resolverse en una despedida más o menos definitiva del pasado. Porque el «adiós, Ítaca» de Vittorini es ya el de los «muchachos hambrientos, con hambre de ciudades nuevas y de ver mundo", ${ }^{153}$ y el sciasciano «quiero ver cosas nuevas». ${ }^{154}$ Es, pues, el «adiós, Ítaca» de Diario público, de 1957, pero que parte ya de Conversación en Sicilia (19381939); “conversación» que, entre 1941 y 1956, Oreste Macrí intuía perdurable en la «busca de la verdad de las familias, de las costumbres, de las ciudades (Vittorini [«entre los mejores, los más selectos y generosos» en absoluto] está entre los poquísimos directamente comprometidos en tal sentido)». ${ }^{155}$

A partir de una semejante alegoría del sentimiento y de un compromiso no tan lejano, continuamente traído y llevado desde la segunda mitad de los años treinta hasta la segunda mitad de los cincuenta, se podrían aproximar El recuerdo de la Vasca — relato aparecido en la compilación homónima de $1938^{156}$ y «auténtica primera toma de conciencia literaria y moral de Delfini»— ${ }^{157}$ y Una historia, con la que el autor acompaña, entre instrucciones y testimonios, la segunda edición de la misma compilación, presentada en 1956 con el significativo título de Ricordo del Ricordo della Basca (Recuerdo del Recuerdo de la Vasca). ${ }^{158}$

153 Vittorini, Diario in pubblico, cit., p. 212. Cfr. una reseña cómplice de Raffaele Crovi, aparecida en Stato Democratico el 5 de noviembre de 1957, reeditada como núcleo duro de un reciente libro suyo, Vittorini cavalcava la tigre. Ricordi, saggi e polemiche sullo scrittore siciliano, Avagliano, Roma, 2006, pp. 73-77.

154 Sciascia, L'antimonio, cit., p. 230.

155 Macrí, «L'«astratto furore» di Elio Vittorini» (1941), en Macrí, Caratteri e figure della poesia italiana contemporanea, cit., pp. 347 (y 345).

156 Antonio Delfini, Il ricordo della Basca, Parenti, Florencia, 1938.

157 Giuseppe Marchetti, Delfini, col. Il Castoro, La Nuova Italia, Florencia, 1975, p. 26.

158 Cfr. Delfini, «Una storia», en Il ricordo della Basca. Dieci racconti e una storia, Nistri-Lischi, Pisa, 1956, pp. 9-109, luego en I racconti, Garzanti, Milán, 1963, pp. 7-96, y finalmente, como "Introducción" a Il ricordo della Basca, col. Opere di Antonio Delfini, Einaudi, Turín, 1982, pp. 3-62, que adopta el texto de la 2. a ed. (1956) — «rigurosamente supervisado por el propio Delfini, y revisado con respecto a la primera edición (1938)»—, y sigue la 3. a ed., genéricamente titulada I racconti (1963), solo para el denominado fragmento "Il 10 giugno 1918», publicado en L'Illustrazione italiana, agosto de 1961, pp. 75-85. Para estas y otras informaciones, véase la «Nota del editor» Einaudi, p. 173, y para la importancia del "fragmento", que «debería haber sido la novela de la vida de 
Nos encontramos, desde luego, ante una narrativa distinta a la de Conversación en Sicilia y ante un escritor que no es Vittorini, no obstante pertenezcan a la misma generación. Dato este nada secundario, especialmente a comienzos de siglo, pues el fascismo, paradójicamente, logra reunir frente a sí, entre la época del consenso y de su disipamiento en la segunda mitad de los años treinta, a muy diferentes intelectuales antifascistas. (Delfini será también autor, en 1951, de un Manifiesto por un partido conservador y comunista ${ }^{159}$ "donde sintetiza su visión política personal, definible como una aproximación "monárquico-marxista" »). ${ }^{160}$

Dada la evidente diferencia que existe entre Vittorini y Delfini, las incursiones en la Guerra de Espańa — que buscamos en esos mismos años y en forma "epigramática», como diría Garosci- son muy significativas y pueden ayudarnos, a medida que las subrayemos, a entender mejor una actitud de los narradores italianos ante la guerra civil española en la segunda mitad de los años treinta.

El recuerdo de la Vasca arranca con "un agosto calurosísimo», que casi nos traslada a las páginas de El Gringo y su larguísimo verano de 1936, del que antes se hablaba. No es un viaje en el espacio, por mucho que se confíe a un falso reportaje, lo que estructura el relato. Se trata de un viaje en la memoria, similar en parte al de Conversación en Sicilia pero con un aparato lírico y simbólico más conciso, en consecuencia menos reiterativo y sobrecargado. Emerge, en definitiva, ese «delicado poeta de la Vasca» del que habla Cesare Garboli al presentar a Delfini a los lectores, en el texto de cubierta de la edición de Einaudi (1982), a la que haremos referencia. ${ }^{161}$

Delfini», léase, también en relación con El recuerdo de la Vasca, Marchetti, «El relato como confesión", en Delfini, cit., p. 28. En fin, para el recuerdo a la segunda potencia, como práctica del mundo narrativo (y crítico) de Delfini, cfr. Giulio Ungarelli, "Ricordare un ricordo, sognare un sogno", en Antonio Delfini tra memoria e sogno, Bulzoni, Roma, 1973, pp. 51-67.

159 Antonio Delfini, Manifesto per un partito conservatore e comunista in Italia, Guanda, Parma, 1951.

160 Cfr. Piero Luxardo Franchi, "Contro-passato remoto di Antonio Delfini», en L'altra faccia degli anni trenta, pról. Silvio Ramat, CLEUP, Padua, 1991, p. 83.

161 Delfini, Il ricordo della Basca, cit., pensado como 2. ${ }^{\circ}$ vol. de las «Obras de Antonio Delfini», tras los Diarios, que contienen una distendida y densa aportación de Cesare Garboli, «Prefacio», en Antonio Delfini, Diari 1927-1961, ed. Giovanna Delfini y Natalia Ginzburg, Einaudi, Turín, 1982, pp. V-XLVI. Pero véase, además, Garboli, Scritti servili, Einaudi, Turín, 1989, pp. 29-91, y Storie di seduzione, Einaudi, Turín, 2005, pp. 9-49 
En relación con la muchacha vasca de la que el protagonista se enamora de joven, en los «años que van de 1912 a 1914, entre la guerra de Libia y la guerra europea ${ }^{162}$ y a la que recuerda, presa de una crisis existencial y civil al estallar la guerra española, el «delicado poeta» trabaja ya en ese «anticancionero» que son las Poesie della fine del mondo (Poesías del fin del mundo) (1961), ${ }^{163}$ vecinas cronológicamente (y no solo) de Recuerdo del recuerdo de la Vasca, de 1956. Como sugiere con acierto Giorgio Agamben: «Se entiende por qué Delfini, en el prólogo, define las Poesías del fin del mundo como un "anticancionero» [...]. Abandonado definitivamente el espíritu trovadoresco, la vida queda ahora a un lado y la poesía es solo literatura, luto por la irremisible muerte de Laura. Las Poesías del fin del mundo son un anticancionero, porque es precisamente esa ruptura la que Delfini no logra aceptar a ningún precio. De aquí la furiosa guerra que el poeta, con sus últimas fuerzas, libra contra la "realidad", que es en la misma medida una lucha por la poesía, para que las Poesías del fin del mundo nunca se conviertan en un cancionero». ${ }^{164}$

Delfini muere poco después, en 1963, pero la furiosa guerra contra la «realidad» y por la poesía comenzó mucho antes: "Quizá [la Vasca] no venga nunca, / quizá la maten, / pero a mi corazón lo han matado / antes de que ella me fuera arrebatada». ${ }^{165}$

Pero procedamos con orden. El breve relato de Delfini se abre en una atmósfera vacacional, que sin embargo permite que la guerra civil asome, rápidamente, en los pensamientos de un hombre «soñador»: «Hacía poco que Giacomo Disvetri había pasado de los cuarenta. Tenía aspecto de sońador, pero se conducía bien en su trabajo de modesto empleado de banca [...] encontrado cuando, perdido de repente todo su patrimonio,

(287-288). Consúltese, en fin, el excelente ensayo de Raffaele Manica, "Rose rosse, per corrispondenza". Una storia di Delfini», en Anna Dolfi (ed.), "Frammenti di un discorso amoroso" nella scrittura epistolare moderna, actas del seminario (Trento, mayo de 1991), Bulzoni, Roma, 1992, pp. 445-472.

162 Delfini, Il ricordo della Basca, cit., p. 133.

163 Antonio Delfini, Poesie della fine del mondo, Feltrinelli, Milán, 1961.

164 Giorgio Agamben, introd. a Antonio Delfini, Poesie della fine del mondo e Poesie escluse, ed. Daniele Garbuglia, Quodlibet, Macerata, 1995, pp. XVIII-XIX.

165 Delfini, Il ricordo della Basca, cit., p. 143. 
no habría sabido cómo seguir adelante. Desde hacía tres días estaba en libertad, por las vacaciones estivales. En Cortina, en el Lido, en el extranjero, hacía muchos años que pensaba ir a España, pero ahora había una guerra civil; mejor ir al cercano Abetone, a la Porretta o quién sabe adónde, quizá a ningún lugar». ${ }^{166}$

Después, la Guerra de España desaparece durante casi todo el relato, pero se nota que los «abstractos furores» de Delfini están al acecho, a medio camino entre la memoria y el sueño. Indicios de ello son su constante referencia a España y los españoles, aparte la Vasca, ${ }^{167}$ y fáciles apuntes, por implícitos: «el padre de la chica [...], el profesor Aranzadi, de Guernica, un famoso geólogo vasco llegado al golfo de la Spezia para hacer importantes estudios». ${ }^{168}$ Más adelante, hacia el final del relato, emerge el sońador, escondido furor delfiniano, como un «rencor que no se apagaría jamás» en cualquiera que no aceptase «la eterna desaparición de la Vasca». ${ }^{169}$

¿Cuántas jornadas habían transcurrido juntos, él y la Vasca? [...]. ¿Cómo habría podido llegar jamás el día en que la Vasca desapareciera? ¿Era siquiera posible pensar en ello? ¿Y cuál habría sido ese día? [...] Seguro que un día de octubre, ese día en que habría tenido que oírse de una camarera: «El señor Profesor y la seńorita se han ido» [...]. Se puede pensar, sí, en un mal día, en un cataclismo, un terremoto, una guerra que nos haga desaparecer a todos o al menos a gran parte de nosotros.

[...]. No conocemos las representaciones mentales de la Vasca el día en que Giacomo (transformado e identificado por su voz, convertido en hombre de amor) se construía las suyas ante los de casa, mientras se desarrollaban una comida y una tormenta [...]. Quienquiera que viésemos con una sonrisa, o con alegría de vivir, toparía con nuestra desaprobación y sería perseguido por nuestro rencor, que no se apagaría jamás. Ese jamás que dura tanto cuanto puede durar la eterna desaparición de la Vasca. ${ }^{170}$

En la Historia de 1956, especie de pequeño «diario público» («diciembre de 1935 [...]. Navidad de 1936 [...], principios de la primavera de 1937»), ${ }^{171}$ el escritor modenés "confiesa» veinte años después — precisa-

\footnotetext{
166 Ib., p. 129.

167 Ib., pp. 129, 133, 136, 140, 142.

168 Ib., p. 134.

169 Ib., p. 140.

170 Ib., pp. 139-140.

171 Ib., pp. 55-60.
} 
mente los veinte años después vittorinianos- haber escapado a la censura del minculpop* porque, a fin de cuentas, se había "escondido demasiado», haciendo incomprensible su "gran mensaje a la humanidad»; ${ }^{172}$ mensaje no tan lejano de los "furores [...] por el género humano perdido» de Vittorini y cuya transfiguración en el relato adopta también una suerte de «alegoría del sentimiento», donde la Vasca sería el "género humano perdido».

Leamos una parte de la «confesión» delfiniana:

Estalló la guerra civil española. Yo estaba en Viareggio. Conocí en Forte dei Marmi a gente que huía de Barcelona. Eran fascistas españoles en casa de fascistas. Todo me producía un asco colosal. Me parecía estar viviendo dentro de una jaula con paja y estiércol. Venía a verme un cierto escritor antifascista que tenía contactos con el Ministerio del Interior y decía haber sido comunista. Era un infeliz: amaba los objetos y tenía miedo a gastar. El mundo me consideraba su gran amigo. Yo era un débil, siempre lo he sido. Me venía a recoger a casa y, con mi automóvil, me llevaba a conocer todos los matices de la buena sociedad. A pesar de las diferencias que encontraba entre un grupo y otro, nunca he logrado llevarme a casa una sola imagen que los distinguiese [...]. Solo cuando me persuada de que en esos grupos mundanos y artísticos no había otra cosa que falsedad y, por tanto, fealdad, solo entonces podré sosegarme con lo bonito, con lo artístico. Pero con el buen gusto, jamás. Existe una razón por la que nunca haré las paces con el buen gusto. Porque también lo inhumano puede tener algo de buen gusto. $Y$ yo tengo la intención, con todas las fuerzas morales que aún me quedan, de romper cualquier lazo con lo inhumano.

Tentativas de romper lazos con lo inhumano, las había hecho siempre. La sociedad corría hacia la más absoluta inhumanidad. Se inauguraba el inhumanismo italiano, que en los días en que escribo ha llegado, parece, a su concreta estabilización [...].

Estalló la guerra civil española. El pueblo al que di toda mi simpatía fue el pueblo vasco. Era el más antiguo de todos los pueblos de Europa..., y en esa época yo era regionalista. (Hoy ya no lo soy, porque el partido dominante en Italia tiende a confundir la región con un supergobierno civil.)

[...]

Fue un día a principios de la primavera de 1937, en la estación de Florencia, mientras esperaba el tren de costumbre para Bolonia. Había olvidado la guerra civil, la historia antigua y moderna; no leía los periódicos que tenía en la mano [...]. El niño habrá cumplido diez ańos; ella, quince [...]. Él parecía salir de un cuadro de Velázquez. Ella recordaba, sin parecérsele, a aquella Virgen del Greco [...], podía ser, viviendo de improviso y niña, la señora más adorada de mi vida: esa que está en un sillón en un cuadro de Cézanne. Pero

* N. de los T.: Acrónimo del Ministerio de la Cultura Popular, encargado de la propaganda fascista y de la censura de prensa.

172 Ib., pp. 61-62. 
también era (sobre todo, quizás) una Virgen del Greco [...] llena de una felicidad serena que el mundo ya no podía tolerar.

Han pasado diecinueve años desde aquel día de principios de la primavera de 1937, y aquel encuentro vuelve a estar, como lo estuvo siempre, lleno de reproches, de perspectivas y esperanzas. Vine en llamarla la Vasca. La guerra civil española estaba convirtiéndose en la primera y auténtica gran tragedia de la humanidad. La imaginé de vuelta en su país. La imaginé fugitiva. Pensé en ella como hija del cabecilla de la revuelta. El destino de los vascos fue entonces terrible, devino trágico, y acabó por desvanecerse entre otras tragedias más grandes. Mi ambición se transmutó. Quise escribir un libro, un gran mensaje a la humanidad. Hacer entender a los italianos, sin incurrir en la censura o en los castigos del régimen, que yo estaba con y contra los vascos. Hacer que ella leyera mi libro y encontrármela de nuevo. Tenía que actuar deprisa, antes de que terminase la guerra y todo estuviese perdido. Salió una cosa ambigua que nadie entendió, un relato titulado El recuerdo de la Vasca.

Después de haberlo escrito, no encontré revista que me lo publicase. Estaba a punto de destruirlo. A amigos de particular altura les confié mi secreto: todos se rieron por lo bajo. Un año después entregué el texto a máquina a Bonsanti, para la editorial de los hermanos Parenti.

El libro fue detenido por el minculpop y después liberado, por intercesión de Arrigo Benedetti, a condición de que se suprimiesen las palabrotas de algún relato. Tampoco el ministerio había entendido nada de mi mensaje, de mi instigación a la revuelta. Quizá me había escondido demasiado. Incluso los lectores más atentos no entendieron nada. Efectivamente, quizá lo había hecho de tal modo que no se entendiera nada. En cualquier caso, cuando el libro pudo salir, no tuvo difusión. Es más, fue el menos difundido, de la colección menos difundida, del editor menos difundido en Italia [...] Pido perdón al lector por el largo prólogo, o como se lo quiera llamar, Recuerdo del recuerdo de la Vasca; por ahora le pido que no me pregunte (si es que llega a leer el libro) "¿Por qué la Vasca? ¿Quién es? ¿Qué quiere decir?». ${ }^{173}$

18 de abril de 1956: «también lo inhumano puede tener algo de buen gusto». Viene a la mente George Steiner cuando, diez años después, en septiembre de 1966, introduce varios ensayos escritos entre 1958 y 1967 y recogidos en Lenguaje y silencio (1967): "Ahora sabemos que un hombre puede leer a Goethe o a Rilke por la noche, interpretar a Bach y a Schubert, y luego, a la mañana siguiente, dirigirse a su trabajo en Auschwitz». ${ }^{174}$ A exterminar judíos. Antes, a matar al pueblo vasco, español, pero yendo siempre hacia «la absoluta inhumanidad» y dando lugar, también, al «inhumanismo italiano».

173 Ib., pp. 57-62.

174 George Steiner, pról. a Linguaggio e silenzio, Garzanti, Milán, 2001, p. 9 (Lenguaje y silencio: ensayos sobre literatura, el lenguaje y lo inhumano, trad. Miguel Ultorio, Tomás Fernández y Beatriz Eguibar, Gedisa, Barcelona, 2003). 
Los furores delfinianos revelan esta triste herencia, casi con la misma matriz, desde los años treinta hasta los cincuenta y sesenta. 29 de abril de 1960: «Las poesías [...] se inspiran de algún modo en un presagio: tener que ser espectadores del fin del mundo, que no se sabe cuándo llegará o cuándo llegó. El fin del mundo puede ya haber llegado. El poeta intenta recordar [...]. El poeta quiere al pasado: ve una Niña con una rosa en la mano, que llevará la salvación al mundo a punto de acabarse o traerá el olvido al mundo que ya ha acabado». ${ }^{175}$

Vittorini y Delfini se miden, en potencia, con el silencio, con el silencio de la «absoluta inhumanidad» y con el «inhumanismo italiano» del que no pueden "hablar», en razón del contexto histórico-político que alberga su escritura, que ensaya, de todos modos, el silencio de la «absoluta inhumanidad». En ese sentido, su asiduidad al silencio no equivale a callar, ni hay que confundirla con un simple «no decir» de mudos. Claro que Vittorini y Delfini aspiran a traducir el «inhumanismo italiano» mediante un "ejercicio del silencio» un tanto particular, que conlleva una poco evidente «inefabilidad entre interior y exterior», ${ }^{176}$ fácil de criticar en su más inmediata vertiente política. Los dos escritores lo saben, y veinte años después buscan la ocasión de volver sobre su desafío, ya para explicarlo, ya para desarrollarlo.

Por otro lado, para esquivar el puro discurso filosófico, aquí apenas aludido, y dar la vuelta al discurso político de Garosci, apuntemos que lo que voluntariamente queda fuera del desafío de Vittorini y Delfini es el mundo como espectáculo, España como espectáculo. Ese mundo que, sobre todo, se impone en los textos de propaganda, pero que aflora también, parcialmente, en territorios más sensibles (literarios, legendarios, fol-

175 Delfini, pról. a Poesie della fine del mondo, cit., y ahora en Poesie della fine del mondo e Poesie escluse, cit., pp. 5-6. Cfr. "Amenazamos con hacer la guerra», del 9 de mayo de 1959, pp. 29-31.

176 Pienso, adaptándolo, en Rovatti, «L'esercizio del silenzio. Postilla a Derrida», en el rico volumen de Carlo A. Augieri (ed.), La retorica del silenzio, Milella, Lecce, 1994, p. 64: «inefabilidad entre interior y exterior, proximidad y lejanía, y en fin, poco más tarde, entre amigo y enemigo. De hecho, no sabemos decir si la voz está dentro o fuera de nosotros, y ni siquiera estamos seguros de poder afirmar, como creemos, que está dentro $y$ fuera, porque es precisamente esta distinción entre dentro y fuera la que ya no logramos leer ni sostener». 
clóricos); ese mundo en sordina que hemos valorado en relatos que, hacia mediados de los años cuarenta, toman distancia de unos y otros, como $E l$ viejo con botas (1944) de Brancati, ya recordado en el capítulo primero, donde Piscitello reprocha a su mujer que vea a Espańa, precisamente, como espectáculo.

Es más, quien en la segunda mitad de los ańos treinta no amortigua las voces que colman aquel periodo recurriendo al silencio, al modo de Vittorini y/o Delfini, arriesga un compromiso más difícil que en el caso del «epigrama» vittoriniano o el «silenciador» delfiniano. Es lo que en el fondo sucede, en mi opinión, con una obra casi redescubierta por la enciclopedia Literatura italiana de Einaudi, dirigida por Asor Rosa, con la complicidad de Laura Fortini: Nessuno torna indietro (Nadie vuelve atrás) (1938) de Alba De Céspedes, quien, tras la breve novela Io, suo padre (Yo, su padre) (1935), una compilación de poemas líricos, Prigionie (Prisiones) (1936), y dos de relatos, L'anima degli altri (El alma de los otros) (1935) y Concerto (Concierto) (1937), llega a su primer texto de cierto empeño, incluso cuantitativamente (cuatro largos capítulos o "partes», para un total de 458 páginas). ${ }^{177}$

Se trata de una interesante novela de formación, de carácter simbólico, que a menudo va más allá de un argumento construido en torno a un colegio de monjas, en Roma, con muchachas en busca de una licenciatura y un marido. Lo que choca, desde nuestro punto de vista, es que en una novela donde no hay muchas ni fuertes referencias a la realidad política de la época o al fascismo («—¿Está inscrita en el partido? -En el GUF»;* «a duras penas se abrieron paso entre la multitud que se agolpaba en la plaza, atenta a la lotería que se sorteaba en el balcón de la Casa del Fascio»), ${ }^{178}$ la Guerra de España se imponga con una continuidad verdaderamente notable, de manera extensa y en al menos una docena de momentos. ${ }^{179}$ Claro que la Guerra de España llega a ser casi estructurante, porque Vinca, la

177 Alba De Céspedes, Nessuno torna indietro, Mondadori, Milán, 1938. Léanse las páginas que Laura Fortini dedica a la novela, en Alberto Asor Rosa (ed.), Letteratura italiana. Le opere, vol. Iv/2, Einaudi, Turín, 2000, pp. 137-166. Cfr. también Letteratura italiana. Dizionario delle opere, vol. II, Einaudi, Turín, 2000, pp. 101-102.

* N. de los T.: Sigla de Gruppi Universitari Fascisti (Grupos Universitarios Fascistas).

178 De Céspedes, Nessuno torna indietro, cit., pp. 70 y 243.

179 Ib., pp. 117-120, 153, 170-178, 186-191, 236, 267-276, 316-317, 321-325, 359, 387-392 y 395-397. 
primera colegiala que aparece en la novela, es española y, cuando estalla el conflicto, abandona el colegio para esperar en un apartamento de compatriotas acomodados la vuelta de su novio que ha ido a alistarse en Falange; ${ }^{180}$ ese Luis que "animado discutía, hablaba de España roja, España martirizada, iglesias desventradas por las bombas, mujeres arrojadas al mar en sacos, niños con las manos cortadas». ${ }^{181}$

Vinca espera a Luis junto a otra muchacha, Pilar, y la madre de esta, dońa Inés, que la acoge con el consentimiento de su padre, «refugiado con su mujer en Portugal». "Sí, ven, querida", le había dicho: "Así no me queda solo mi Pilar. Todos juntos, todos juntos. No se puede quedar uno entre extrańos que no entienden lo que estamos pasando" ${ }^{182}$

La «rica doña Inés», por lo demás, detesta a los «rojos», que de su "casa de campo en Osuna habían hecho una especie de cuartel general», ${ }^{183}$ y se presenta poco antes en una cháchara sin freno, casi un monólogo de gran guiñol, melodramático, anecdótico, hasta divertido por el uso del español y las interrupciones de Pilar, pero llevado de un «aristocrático» odio hacia los rojos — «esas fieras»— y bien distinto del monólogo brancatiano de El guapo Antonio, citado más arriba:

—Esta mañana entra en mi habitación la criada, ${ }^{*}$ ¡cómo decís vosotros?, la «cameriera», y me dice: "Hay una seńorita que viene de España”. ¡Figúrese! Yo estaba ahí, despeinada, en camisón, pero había dicho "de España»; voy en seguida, contesto: que espere, que espere. Voy y encuentro a una criatura preciosa, hermosísima, rubia, delgada. Rubia platino, igualita que una artista de cine. La mandaba a mi casa una amiga mía, una vieja amiga a la que esas fieras le han matado el hijo sin más, ni amos ni Dios, una bala en la espalda, ¡pum!, con veintidós años. Por eso la chica estaba pálida, como de cera, la pobrecita: se ha salvado de milagro, que la querían fusilar por ser la novia de un falangista. Ha estado encarcelada un mes, con otras mujeres: gente de la

180 Ib., p. 176.

181 Ib., p. 172. Resulta difícil compartir las conclusiones de Fortini acerca de «Luis, implicado en la Guerra de España en nombre de un ideal político y en defensa de una patria lejana de la que él mismo no tiene perfiles nítidos" (Letteratura italiana. Le opere, cit., p. 153; pero cfr. p. 148).

182 De Céspedes, Nessuno torna indietro, cit., pp. 189 y 188.

183 Ib., p. 188.

* N. de los T.: Las siguientes palabras y frases aparecen en español, en el original: «criada», "pobrecita», «ya lo creo», "sotano» (sic), "Vamos de paseo», «muchacha», "Es domingo", "Bueno, no?» (sic), "Las pobrecitas se van como al martirio», "Vamos», "a pasear», «Viva la falange!» (sic), «Viva la falange! Viva la falange!» (sic). 
aristocracia, dos monjas y una mujer embarazada. La arrestaron en medio de la calle: «venga con nosotros», y en seguida pensó: aquí me matan.* Así que la arrestan...

Pilar la interrumpió:

- Sí, pero di antes que no es española, pues en el consulado...

- Ah, es verdad, es verdad. Ella es norteamericana, pero le gusta España, ya lo creo. La madre es espańola y vive en España. En el consulado americano le dicen que esté tranquila, que es súbdita americana y no pueden hacerle nada, que no la tocarán, pero ésos, qué va, para nada te piden los papeles. De modo que encarcelada en, ¿cómo se dice?, en un sótano, con las otras. Dos salieron de allí solo para ser fusiladas. Las llaman diciendo: «Vamos de paseo»; un paseo, y ya no vuelven. Ha llegado aquí exhausta, muerta de hambre; me lo contaba todo mientras le daba la sopa. Día y noche las monjas rezaban y la mujer embarazada lloraba, hasta que un día comienza a quejarse y luego se pone a gritar: los dolores del parto. Veinticuatro horas de dolores, y chillidos, chillidos. Esas fieras ni siquiera se acercaban, y ellas golpeaban la puerta: nada, solas allí, como perros, a oscuras. Las monjas ayudaban a aquella pobrecilla que, por fin, al día siguiente, se libera.

-Muerto, el niño - interrumpió Pilar. Doña Inés la miró mal, porque le había quitado las palabras y el efecto. Luego continuó, más despacio:

-Ya, muerto. Y la madre medio desangrada, allí, en medio de la suciedad, llorando, desesperándose, calentando con su aliento al niño para que volviese a la vida. Al cabo de dos días se llevan el cadáver; la madre tenía la fiebre alta, la infección se agravaba. Las monjas habían vuelto a rezar: aquel bisbiseo, dice la muchacha, nos volvía locas. A la mañana siguiente una de aquellas fieras abre la puerta y dice: «Es domingo; hoy se come asado, liebre asada». Lo devoran todas, hambrientas; también las monjas, y la recién parida. Y luego, desde la puerta, esos dos o tres que ríen a mandíbula batiente. "Bueno, ¿no?», y reían como borrachos. «¿Sabéis lo que era la liebre? ¡Pues era el niño!».

[...]

- Se ha salvado de esta manera. Al día siguiente, vuelven las fieras y se llevan a las monjas. Las pobrecitas se van como al martirio. Pero luego vuelven y ya no rezan, tiradas en un rincón, sin las cofias, los cabellos cortos desordenados. Poco después la llaman a ella, a la muchacha: "Vamos», dicen, "a pasear». Me ha dicho que no tenía miedo, se ve que tiene sangre fría: mejor morir que esta pesadilla, pensaba. Las otras lloraban y ella que se va con ellas. Dice que lo había decidido: antes de que disparen, chillo «iViva la Falange!». Al menos el novio lo habría sabido. Y luego, ¿sabes?, como en las películas: en el último momento llega el cónsul y se la lleva, desmayada. Ha estado diez días en su casa, delirando; gritaba siempre «iViva la Falange! ¡Viva la Falange!». Y escupía, porque sentía en la boca el sabor de aquel niño muerto. ${ }^{184}$

No estamos ante el registro mecánico de los tópicos de la propaganda, y la enfática oralidad de dońa Inés parece producir un efecto de dis-

* N. de los T.: «matano», conjugando a la italiana el castellano matar, en el original. 
tancia, hasta el punto de que podría pensarse en un enmascaramiento e inversión de aquellos, si no fuera porque en seguida encontramos a los italianos «Emanuela y Andrea [...] aterrorizados, como si esa tragedia debiera arrastrarles también a ellos», y el joven pregunta a la muchacha: «-Sí, pobrecillos. ¿Qué haríamos nosotros, exiliados de la patria? [...]. ¿Podrías tú vivir fuera de Italia?». Es verdad que en la vicisitud de Emanuela (y de la propia Vinca) lo privado femenino se impone a lo público, como decíamos, poco frecuentado, pero en el contexto ampliado de la comunidad española nacionalista — los refugiados en Italia o Portugal— el horizonte colectivo no puede archivarse fácilmente.

Publicado en 1938 por Mondadori, una de las editoriales de mayor difusión, con gran éxito de crítica y público, Nadie vuelve atrás - que exhibe fragmentos como el citado y otros, más o menos significativos, en ese sentido- no debería haber sido "detenido por el minculpop». Pero los caminos del fascismo son realmente «infinitos», y la decimoséptima reimpresión de la novela es bloqueada por la censura fascista. Laura Fortini — que pasa de puntillas por la guerra civil, aun reconociendo su poderosa presencia en el texto- explica: «En la capacidad de representar este sentimiento de transitoriedad e incertidumbre [el de una generación a las puertas de un suceso de época: la guerra y sus horrores] reside probablemente el inesperado éxito editorial de la novela, cuya potencialidad subversiva fue intuida por el régimen fascista, que trató de obstaculizar su difusión». Difusión que continúa «semiclandestinamente hasta bien avanzada la guerra»y, con otras ediciones y reimpresiones, entre 1952 y 1990. Sin embargo, al menos por lo que respecta a su primera novela de gran aliento y quizá por esa ambigua presencia de la guerra civil española, parece que De Céspedes haya sufrido el destino que arrastra a una parte no despreciable de los escritores españoles, los escritores falangistas, de quienes Javier Cercas, «en frase acuñada por Andrés Trapiello», dice que «habían ganado la guerra, pero habían perdido la historia de la literatura». ${ }^{185}$

Una afirmación fuerte — aunque sustancialmente válida — en su contexto de origen, pero que pierde su mordiente si se proyecta al futuro de

185 Javier Cercas, Soldati di Salamina, Guanda, Parma, 2002, p. 18 (Soldados de Salamina, Tusquets, Barcelona, 2001, p. 22). Cfr. una vez más el ensayo de Laura Fortini en Letteratura italiana. Le opere, cit., p. 142. 
la autora (incluido el cinematográfico, pues la novela se convierte en película en 1943, bajo la dirección de Alessandro Blasetti y con la colaboración de De Céspedes en guión y diálogos) y al contexto narrativo italiano, que en las décadas siguientes, extrañamente, no logra liberarse de lo que llamaríamos — dejando aparte la fuerza del lenguaje que se mide con el silencio— «bloqueo» vittoriniano-delfiniano.

Es difícil no entrever ciertas consecuencias, después de los «regresos» de Delfini y Vittorini en 1956-1957 y dentro del prolongado interés sciasciano de los ańos cincuenta y sesenta. Pienso, de nuevo, en el complejo proceso narrativo que Leonardo Sciascia pone en marcha, anticipando interesantes fragmentos como La sexta jornada y El soldado Seis, ambos de $1958,{ }^{186}$ en la traducción de La velada en Benicarló (1939) — junto a Salvatore Girgenti-y, sobre todo, en el prólogo a ese amargo diálogo sobre las causas y las consecuencias de la guerra civil que es el texto de Manuel Azaña, publicado por Einaudi en $1967 .{ }^{187}$ Pero más que este prólogo y que La sexta jornada, que tienen un valor más crítico que narrativo, como se deduce fácilmente de las citas que hemos ido dando, El soldado Seis (1958) es el texto que juega narrativamente con El antimonio (1960), como si fuera su origen compositivo, entre Hemingway y Vittorini, en el ámbito de una "charla» y de una «serena conversación» en Sicilia.

Ayer por la tarde, en una casa de campo en lo alto de Palermo - la ciudad velada por la calima del siroco-, hablé durante unas horas de la Guerra de España con un joven sacerdote español y un ex oficial italiano del Tercio. Ha sido una serena conversación [...].

El oficial del Tercio hablaba de Líster, el picapedrero de Galicia que se había convertido en general del Ejército popular; un hombre que sabía vivir, y que sabía combatir: magnífico, decía el hombre del Tercio. El cuerpo de ejército de Líster siempre estaba, indomable, plantándole cara al Tercio. ${ }^{188}$

Recordado por sus memorias en el capítulo primero, a propósito de Horas de España, ${ }^{189}$ de 1988, Líster comparece también en El antimonio, en concreto en el pasaje de las mariposas, que extracté para subrayar el itinerario del fuego, el miedo, la memoria y la infancia en relación con el

186 Sciascia, "La sesta giornata», Officina, 7, 1958; luego en AA. VV., La noia e l'offesa, cit.; y Sciascia, «Il soldado Seis», Valbona, 1, 1958, pp. 3-5.

187 Sciascia, pról. a Manuel Azaña, La veglia di Benicarló, cit., pp. VII-XIII.

188 Sciascia, Il soldato Seis, cit., p. 3.

189 Sciascia, Ore di Spagna, cit., p. 29. 
protagonista. Dos años antes, en 1958, Líster es ya una leyenda que surge de lejos y lejos permanece, en cierto modo, cuando se escucha sosegadamente el testimonio de una guerra distante en el tiempo, cuyo recuerdo llega en la serenidad de una conversación y con el humor del ex oficial italiano del Tercio, que "en la última batalla» acepta «la última mofa del general picapedrero [...], el mono de Líster»:

El oficial italiano, que sabía seguir una broma, eligió entre los legionarios a uno que se pareciese al mono y se lo dio para que se lo guardase; y había fotografiado — pausa heroicómica en la gran tragedia - la entrega del mono al legionario. ${ }^{190}$

La exorcizante "pausa heroicómica en la gran tragedia», creada a fin de cuentas por Líster el picapedrero, el héroe del pueblo, casi en el ámbito de lo grotesco bachtiniano, ${ }^{191}$ deja paso en El antimonio a una visión más realista y cercana de Líster, un combatiente menos hábil, menos seguro de sí mismo — al menos en la circunstancia evocada en el pasaje de las mariposas- y más próximo al «jornalero» en su manera de pensar la guerra, de hacerla y sufrirla:

Llegó la ventolera de Brunete, los republicanos se nos echaron encima por sorpresa y mi admiración por los generales cayó de golpe, pues podían habernos cogido, como se suele decir, en pleno sueño. Y no avanzaron arrollándonos quizá porque se sorprendieron de aquel vacío, temieron una trampa preparada, y en cambio no había nada de eso. Superaron la encrucijada de Brunete y pararon su carrera. Líster, que era su general, dio en aquella ocasión demasiado crédito a nuestros generales: como jornalero que había sido, pensaba, como yo, que los generales lo veían todo, y que dejar un vacío como aquel en el frente de Madrid respondía a algún secreto cálculo. Cuando se dio cuenta de que habría podido lanzarse más allá, era ya tarde [...], obligamos a las fuerzas de Líster a defenderse; el éxito inicial, que no supo explotar a fondo, fue anulado al cabo de diez días. ${ }^{192}$

Sin embargo, el general de la república está aún muy firme en el curso de la guerra, y El antimonio lo recuerda: «El 28 de diciembre atacamos a Líster con grandes fuerzas, pero la ofensiva se estrelló contra sus posicio-

190 Sciascia, Il soldato Seis, cit., p. 3.

191 Cfr. Mijaíl Bajtin, L'opera di Rabelais e la cultura popolare. Riso, carnevale e festa nella cultura medievale e rinascimentale, Einaudi, Turín, 1979 (1965), pp. 332-404. (La cultura popular en la Edad Media y en el Renacimiento: el contexto de François Rabelais, trad. Julio Forcat y César Conroy, Alianza, Madrid, 1998).

192 Sciascia, El antimonio, cit., p. 190. 
nes como una vasija* contra un muro». ${ }^{193}$ Y lo recuerda más allá de la intuición heroicómica de El soldado Seis, confiada a una fotografía que hace surgir otras, familiarmente, de «una gran caja llena de fotos y papeles de la guerra espańola». Porque en su visión se concentra la densidad sin fin de la guerra civil, adecuándola a la forma breve, ${ }^{194}$ con una estructura mitad artículo, mitad short story, en la que emergen imágenes e ideas desarrolladas luego en El antimonio:

Y acabamos pasando, uno tras otro, fotografías y papeles. La nieve en Teruel. El barro de las jornadas de Guadalajara. El asalto de los moros y los soldados de Navarra. Las filas de nuestros pobres legionarios a lo largo de las cañadas de Castilla y Cataluña (el sacerdote español creía que eran voluntarios nuestros legionarios, por la fe de Cristo; le expliqué que iban a combatir a España a causa del desempleo y el hambre que pasaban en Italia). Los campanarios de las iglesias desde donde los milicianos disparaban hasta el final. ${ }^{195}$

Es difícil no pensar en el comienzo de El antimonio: «disparaban desde el campanario», y en los párrafos siguientes, comentados en el capítulo primero. Difícil no imaginar una suerte de prerresumen fotográfico que nos llevaría no solo al cercano El antimonio, sino también a las tantas veces citadas Horas de España (1988), con fotos de Ferdinando Scianna y artículos, corresponsalías de la primera mitad de los ańos ochenta. Sin olvidar la intersección narrativa de Puertas abiertas (1987), a las que hicimos referencia en el capítulo precedente viendo cómo recurre la guerra civil en el último Sciascia, todavía fuertemente ligado al primero por su atención al elemento español, contrastado primero con Sicilia y luego ampliado, más acá y más allá de la guerra, que es también su revelación, y su condenación, en el presente.

Leamos, en este sentido, la que podría ser segunda parte — con menos narración y más reportaje— de El soldado Seis:

El año pasado me detuve en Motilla del Palancar durante un par de horas, en uno de esos «paradores» que ofrecen hogareña hospitalidad. Los

* N. de los T.: En el original, quartara, medida de vino y de áridos aproximadamente equivalente a un cuartillo. Aquí traducimos simplemente por "vasija», en ausencia de un vocablo exactamente equiparable.

193 Ib., p. 216.

194 Cfr. Simone Messina (ed.), La forme brève, actas del coloquio franco-polaco (Lyon, 19-21 de septiembre de 1994), Champion/Cadmo, París-Fiésole (Florencia), 1996.

195 Sciascia, Il soldato Seis, cit., p. 3. 
paradores, lugares de descanso a lo largo de las autopistas, son quizá la institución más eficiente que exista en Espańa: nacieron durante la dictadura de Primo de Rivera y son gestionados por el Estado. El de Motilla es el más simpático que he visto [...]. Las camareras, fuertes muchachas de campo vestidas de nítido blanco y negro, todas jóvenes, desempeñan el papel que nuestras mujeres en Sicilia asumen cuando llevamos a un amigo a comer a casa: lo sofocan de atenciones y de comida. [...]. Y había un pan extraordinario [...] de horno de leńa; uno de esos hornos, como en Sicilia, acabados en cúpula árabe [...]. Reencontraba en el olor del pan el campo de mi pueblo: mi casa, las vacaciones estivales de los años de escuela.

De tanto en tanto, silencioso y hocicudo, el director del parador daba vueltas por la sala, entre las mesas: vestía de oscuro; en el ojal, el distintivo de la cruz, la misma que había visto sobre la gorra de los guardias fronterizos. Aparte del distintivo, después de varios días ya sabía reconocer a los fascistas de España: ni jactanciosos ni felices, como durante veinte años en Italia, se sienten los fascistas españoles; algo les corroe por dentro, el miedo o la condenación —en el sentido más propio de la palabra: condenación. Salieron victoriosos de la guerra, gracias a los ejércitos extranjeros; pero ahora caminan, como el torero de Lorca, "con toda su muerte a cuestas». ${ }^{196}$

La vuelta al presente — al presente, sobre todo, de la "conversación», que se revela un engaño y habrá que reelaborar con otro ritmo narrativo, en un relato más vasto, superando a Vittorini- se consuma en «una especie de síntesis» en torno a la «vicisitud» emanada de la postal de un soldado de la república, un lazo más "anónimo» y fecundo que Líster entre pasado y presente:

En Motilla del Palancar, mi breve experiencia de España se consumaba en una especie de síntesis. Una pequeña fatalidad me acercó ayer a los ojos la postal del soldado Miguel Seis: en la fantasía se me encendió su vicisitud de "campesino» y soldado de la república, su destino. Pregunté al oficial del Tercio si todos los prisioneros eran fusilados: tuvo un breve momento de duda y me dijo que los fusilaban, que también del otro lado lo hacían. Ya lo sabía: pero en el engaño de aquella conversación, en lo agradable de la hora, en la piedad universal que nos inflamaba, tuve por un instante la sensación —extravío, ansia- de que el destino del soldado Seis pudiera depender de nosotros, del encuentro entre tres hombres tan distintos y enemigos, tan despiadadamente enemigos y, sin embargo, en aquel momento, cercanos y atentos a no herirnos con las palabras — como si estuviéramos fuera de la historia, fuera del tiempo. Un engaño. ${ }^{197}$

El «engaño», la conciencia del engaño a la que llega El soldado Seis, es también el punto de partida sciasciano para superar, con El antimonio,

196 Ib., pp. 3-4.

197 Ib., p. 5. 
Conversación en Sicilia y lo que dimos en llamar «bloqueo» vittorinianodelfiniano, hasta la reescritura de Diario público a través de los artículos que entrega a L'Ora y Corriere della Sera, entre los ańos sesenta y ochenta, justamente hasta Horas de España. En este sentido, El soldado Seis (1958), anticipando esa obra maestra que es El antimonio, parece compendiar un cuarto de siglo de tradiciones y experimentaciones narrativas, inventadas entre 1936 y 1960. Aunque, claro, le ayuda en esta delicada y nada fácil operación un célebre pasaje de «Breve crónica del régimen» ${ }^{198}$ contenido en Las parroquias de Regalpetra (1956):

Tenía a España en el corazón. Esos nombres — Bilbao, Málaga, Valencia; y luego Madrid, el Madrid sitiado- eran amor: todavía hoy los pronuncio como si floreciesen en un recuerdo de amor. Y Lorca fusilado. Y Hemingway, que se encontraba en Madrid. Y los italianos que, en nombre de Garibaldi, combatían del lado de los que llamaban rojos. Y cuando pensaba que eran campesinos y artesanos de mi país, de todas las partes de Italia, los que iban a morir por el fascismo, me sentía lleno de odio. Iban a causa del hambre. Los conocía. No había trabajo, y el duce les ofrecía el trabajo de la guerra. Estaban cargados de hijos, desesperados; si les iba bien, la mujer debería haberles esperado, a su vuelta, con tres o cuatro mil liras ahorradas; y el duce, claro, les habría recompensado con un puestecillo de bedel o de portero. Pero a dos o tres de mi pueblo les salió mal, se quedaron en Espańa; murieron por el plomo en España para no morir de hambre en Italia. Sentía que me ahogaba el llanto cuando pensaba en estos pobres que iban a morir a España. El potestad* se vestía de negro, entraba en aquellas pobres casas lúgubres y los nińos lo miraban maravillados; ante la noticia, dada con romana altivez, estallaba de roja ira el llanto de la viuda, y acusaba: «Por el hambre se marchó, por el hambre».

Pensando hoy en aquellos ańos, me parece que nunca volveré a tener en mi vida sentimientos tan intensos, tan puros. Nunca más volveré a encontrar tan neta medida del amor y del odio; ni la amistad, la sinceridad o la confianza tendrán tan viva luz en mi corazón. ${ }^{199}$

Pero en los ańos cincuenta, si se mira bien, hay algún otro fragmento narrativo, más o menos autónomo, que podemos recuperar antes de pasar a una época posantimonio. Después de los años treinta de Vittorini, Delfini y De Céspedes, o los cuarenta de Jovine, Pavese y Brancati, tríadas de

198 Sciascia, «Breve cronaca del regime», en Le parrocchie di Regalpetra, cit., y abriendo ahora las Opere. 1956-1971, cit., pp. 34-48.

* N. de los T.: Alcalde del periodo fascista, nombrado directamente por el gobierno. El podestà rescata una institución italiana de los siglos XIII-XIV que tenía en las ciudades atribuciones jurisdiccionales y militares.

199 Ib., pp. 43-44. 
escritores nacidos — con la sola excepción de Jovine, de 1902- entre 1907 y 1911 y, por tanto, adscribibles a la «tercera generación» (19061914), ${ }^{200}$ podemos descubrir textos de la primera mitad de los ańos cincuenta y componer una tríada de autores más articulada, de entre la segunda y la cuarta generación: El comandante es un rojo (1953), de Francesco Fausto Nitti, nacido en 1899; Il prete bello (El sacerdote guapo) (1954), de Goffredo Parise, nacido en 1929, y I passeri (Los gorriones) (1955), de Giuseppe Dessí, nacido en 1909.

Aparte de la tentación crítica de construir tríadas más o menos ejemplares, es de justicia recuperar algún capítulo de El comandante es un rojo, arrojado in toto a la hoguera por Garosci y confinado en el limbo de la nostalgia y del testimonio parcial: «El relato El comandante es un rojo, de Nitti, por mucho que esté escrito con eficacia literaria, es claramente obra de propaganda y de nostálgica evocación». ${ }^{201}$

Leyendo la introducción es difícil sustraerse al juicio de Aldo Garosci. Sin embargo, el recuerdo que la enmarca — «Recuerdo aquella mańana de noviembre de 1936 [...], aquella mañana tomé mi decisión: tenía que partir»— ${ }^{202}$ se asoma al pasado no solo según una conocida expresión histórico-política — «hoy en España, mañana en Italia»—, sino también según los itinerarios histórico-literarios examinados, que añaden un ayer extendido a todos los países y a todos los pueblos levantados contra la tiranía: «Había llegado el momento de combatir al fascismo, no ya desde organizaciones clandestinas o con la propaganda, sino enfrentándolo con las armas. Así como los exiliados italianos de 1821, 1830 y 1848 habían sido acogidos en tierras de España y dondequiera los pueblos se hubiesen levantado contra la tiranía extranjera e interna, así nosotros debíamos ir, desde Francia, desde Bélgica, desde Suiza, desde las Américas, a participar en la lucha entablada en julio de 1936 entre el pueblo español y el movimiento de Franco». ${ }^{203}$

200 Cfr. Macrí en Anna Dolfi (ed.), La teoria letteraria delle generazioni, Cesati, Florencia, 1995. Concretamente, la «Modelización de la teoría generacional» que sigue a la premisa, pp. 23-26.

201 Garosci, Gli intellettuali e la guerra di Spagna, cit., p. 453.

202 Francesco Fausto Nitti, Il maggiore è un rosso, Edizioni Avanti!, Milán, 1953; reed. en la col. Nuovi Coralli, Einaudi, Turín, 1974, pp. 3 y 7.

203 Ib., p. 3. 
Aparte la introducción y capítulos como «iSalud, Nenni!», ${ }^{204}$ el texto de Nitti, por la "eficacia literaria» de que habla Garosci, puede apreciarse desde un punto de vista narrativo si leemos algún pasaje de «Seiscientos anarquistas hacen un batallón» o de "Ocho cornetas para Pepito Díaz», ${ }^{205}$ respectivamente, tercer y decimotercer capítulo (el libro cuenta con 18), pero también sabrosos relatos autónomos donde destacan descripciones de personajes particularmente logradas. En «Seiscientos anarquistas hacen un batallón", por ejemplo, hay dos retratos admirables y opuestos: «el malo» Duval y «el simpático» Pedro Fuertes. Leamos la presentación que Nitti hace de este:

Había hablado un hombre bajo y membrudo; en la cara rojiza le brillaban los ojos y el arco de los dientes, blanquísimos. Estaba de pie en un rincón de la sala y tenía en las manos un bastoncillo de fresno tallado por él mismo. Una cicatriz, que parecía sangrante, le atravesaba una mejilla. Lo reconocí: era Pedro Fuertes, a quien todos llamaban Iría Bien.

Obrero metalúrgico, Fuertes era valiente y jactancioso, célebre entre sus compañeros por sus arranques de ingenio y más aún por esa manía suya de expresar en cada circunstancia, por curiosa y crítica que fuese, los deseos más extravagantes. Si la columna marchaba bajo el aplastante sol estivo, ahí estaba Fuertes que gritaba: «iAhora iría bien un vaso de cerveza!». Si los aviones alemanes o italianos aparecían en el horizonte y los hombres se dispersaban en los campos para esconderse, a la espera del lanzamiento o de la descarga, Fuertes estaba listo para reclamar: "iAhora haría falta un buen café negro y un vasito de cognac!» Por la noche, haciendo patrulla, precedía a sus hombres en la espesa, impenetrable oscuridad, y avanzando cauto y silencioso, desgranaba en palabras roncas el deseo del momento: «iAhora iría bien un bocadillo relleno y una botella!» Esta presencia de ánimo se contagiaba a los compañeros, y a Iría Bien le querían todos. Todos le conocían en Barcelona en 1936 cuando se había encontrado bajo el fuego cruzado de los fascistas que le disparaban desde dos casas de la misma calle. Pedro Fuertes se había echado a tierra en el punto donde se hallaba, en la esquina de una callejuela, y ya no había podido moverse. Primero había respondido al fuego, fría, ponderadamente, con todas las municiones de su máuser; luego se había aplastado contra el muro desconchado de una gran casa. Esperaba filosóficamente la bala que pusiese fin a la broma. Era un blanco bien visible, por muy pequeño que se hubiera hecho; las balas se estrellaban en el suelo alrededor de su cuerpo, resquebrajaban el muro a pocos centímetros de su cabeza, y el polvo rojizo de los ladrillos le caía sobre el cuello y sobre los cabellos. Algunos compañeros, que desde un portón cercano disparaban contra las casas ocupadas por los fascistas, le gritaron en varias ocasiones: «¡Ven, toma carrerilla! ¡No te quedes ahí, Pedro!». Pero él no se había movido. El fuego había cesado, al final, porque los falangistas abando-

204 Ib., pp. 67-76.

205 Ib., pp. 23-34 y 141-152. 
naban las posiciones y, a través de las casas traseras, escapaban al cerco. Entonces, Pedro Fuertes se había levantado, con sus gruesas manos se había sacudido por encima el polvo de su mono de tela azul y había alcanzado a sus compañeros sonriendo. «iPedro, hoy has nacido otra vez!, rió uno. Y él: «¿Sabéis lo que os digo? Ahora iría bien una buena horchata con hielo. Tengo un poco de calor». Y se había marchado de allí, con su paso firme y tranquilo, a reunirse con el comité revolucionario de su barrio. ${ }^{206}$

Un año después de este relato sale El sacerdote guapo, de Goffredo Parise, donde asistimos a la irrupción, en la provincia véneta de la segunda mitad de los años treinta, de don Gastón Caoduro, un «enemigo» de Nitti, ex capellán militar de la guerra civil española que ha escrito un libro similar a España en llamas, de Paolo Sighinolfi: "Don Gastón había sido capellán militar en la Guerra de España y había escrito algunos libros: atrocidades y delitos de los rojos estaban descritos de manera extremadamente conmovedora. Yo había quedado impresionado, y una vez, por incitación de una señorita de nombre Camila, fui a besarle la mano». ${ }^{207}$ Esta impresión de Sergio, un muchacho de unos diez u once años, protagonista y narrador en primera persona, es mitigada inicialmente por el recuerdo del «padre» de Cena, su mejor amigo, que «hizo la guerra de Abisinia y está muerto»: ${ }^{208}$ como afirmando la vinculación, tantas veces sugerida, entre ambos conflictos y en toda Italia, de norte a sur, del Véneto a los Abruzos, de Molise a Sicilia.

Pero cuando llega la famosa «tarde de la función», don Gastón es de nuevo «más un arma que un cura» y, mientras «el abuelo y el tío Gigi, acercando los vasitos, [dicen] claramente “PPor nuestro mártir, por Matteotti!", se imponen otros brindis acompañados del "saludo romano": “¡Viva el Duce! [...] ¡Viva nuestro don Gastón!”»:209

Volvió el silencio y yo comencé a recitar la tercera poesía, sin interrupciones [...], noté que detrás de mí, sobre la pared, estaba desplegada una bandera con el símbolo de la Falange española. Don Gastón me acogió con pequeńos aplausos, me acarició una vez más y me dio veinte liras a escondidas.

[...] Siguieron los recitados de los otros dos y luego, inmediatamente después, llegó la sorpresa de que don Gastón se reservaba para clausurar la velada.

206 Ib., pp. 27-29.

207 Goffredo Parise, Il prete bello, Garzanti, Milán, 1954 (reed. col. I Garzanti, 1965 y 1973, p. 9).

208 Ib., p. 28.

209 Ib., pp. 55-58. 
[...] ante las miradas ávidas de los presentes agitó y volcó aquí y allá el cajón, del que salieron unos paquetes, y de los paquetes una cantidad de libros [...] cuando corrió la noticia de que los libros eran obras suyas, que los había escrito él, las señoritas no pudieron contenerse.

[...] El título del libro era España, fragua de fe y ardor. Y don Gastón lo pronunció administrándolo, con la misma voz que si estuviera ante el banco de los comulgantes: "Corpus Domini nostri Jesus Christi...» «La novela de mi vida durante la Guerra de Espańa... mis citas como capellán combatiente...».

Pero pocos o ninguno le escuchaban [...] las benefactoras [...]. Todas querían el libro con el autógrafo: algunas, escrito al margen de una de las fotografías que adornaban el texto y donde aparecía siempre él; otras, incluso sobre la tapa, donde irradiaba una gran cruz con la bandera espańola de fondo. ${ }^{210}$

\section{Los libros de don Gastón y su destino vuelven en varias ocasiones, en} un contexto de "mujeres católicas», "vales de don Bosco» y hasta el Vate, D’Annunzio, a quien el sacerdote guapo escribe arrastrado por la «ambición» y una "fiebre de gloria comparable, en intensidad, a los sentimientos más íntimos y pecaminosos de las señoritas»:

La señorita Inmaculada, por medio de contactos, había llenado muchas librerías de la ciudad, pero el periódico no habló de ello. Los libreros comenzaron a devolver ejemplares y la señorita Inmaculada encontró remedio también para esto. Amontonó los libros en un chiribitil convertido en almacén y desde allá los repartía a las mujeres católicas que visitaban a las familias con los vales de don Bosco, además de con España, fragua de fe y ardor. De ese modo el libro acabó siendo vendido, y no poco, según las previsiones de la señorita Inmaculada, que, por lo que a especulaciones se refería, era una gran mujer.

[...] todo se vendió, se imprimeron y distribuyeron otras copias en el campo, junto a los boletines de las misiones y los vales de beneficencia: a esas alturas, los vales de don Bosco venían ya metidos entre las páginas del libro, sin muchos subterfugios. Lo compraban mujeres de mediana edad [...], las señoritas de buena familia, y además las muchachas, las modistillas, que iban a oír sus sermones como podían leer los folletines, así como las mujeres de la hilandería a las que don Gastón daba conferencias. "¡Guapo!», decían todas, mujeres católicas o no; algunas de palabra, otras de pensamiento.

[...] Ya no estaba quieto [...] Carta sobre carta, de una punta a otra de Italia: a todos los periódicos, a todos los críticos. Mandó una carta incluso a D’Annunzio: el Poeta no le escribió el artículo, pero, en compensación, le envió un hermoso anillo y un gran diploma de pergamino. ${ }^{211}$

Gabriele d'Annunzio, que muere en 1938, es retratado como auténtico gran escritor, pero Parise lo evoca a las puertas de la muerte, para suge-

210 Ib., pp. 63-66.

211 Ib., pp. 82 y 88-89; cfr. también pp. 90-91 y 117-118. 
rir de modo divertido tanto la desmesurada ambición de don Gastón como el horizonte sobre el que el «sacerdote guapo» va a recortarse, como "gallo» y «amador», una suerte de álter ego del «guapo Antonio» de Brancati, en cuanto hombre y fascista triunfador a los ojos de sus conciudadanos y paisanos más representativos:

El caballero Expósito no hacía estos elogios porque sí, para nada; había toda una serie de razones que alimentaban la admiración. Ya que esta admiración por don Gastón era, en sustancia, la de un aspirante fascista por un fascista triunfador. Para él, don Gastón era un hombre conocido, una figura de Italia, sacerdote también, pero sobre todo héroe de la Guerra de España y, por consiguiente, incansable con las mujeres, un gallo, un amador tal que, sin duda, debía de enfrentarse con diez amantes. La apología de don Gastón no era otra cosa que la apología del partido o, mejor, de las capacidades que, después de la patria, Dios y la familia, tenía que saber demostrar el fascista como hombre de mundo [...] Mussolini tenía dos c... así, de oro [...]. Pretendía incluso demostrar, con tozudez e insistencia, sus descripciones de los atributos de Mussolini diciendo que al duce le había mirado atentamente, en más de una ocasión, para cerciorarse, y que se veía perfectamente, incluso a simple vista. ${ }^{212}$

Terminan por aparecer, en fin, «los primeros uniformes del grupo femenino Fe y Ardor», con sus correspondientes «jefe de manípulo» y «jefe de centuria», ${ }^{213}$ y acaba por hacer su aparición también «el duce [que] habría llegado el domingo»: "la ciudad parecía una familia de huérfanos, en espera del tutor con los caramelos». ${ }^{214}$ Pero la visita se vuelve farsa gracias, precisamente, al caballero Expósito, «desnudo de cintura para abajo», que se las ve con el «desplome del retrete» y «los pedazos [del váter]» que «volaban silbando alrededor». ${ }^{215}$ "el caballero Expósito, tras el desplome del retrete, se había convertido en otro hombre: con el retrete habían desaparecido ideales, honores, dignidades». ${ }^{216} \mathrm{E}$ ideales, honores, dignidades desaparecen también, definitivamente, para el sacerdote guapo cuando enferma de tuberculosis: «todo el barrio había olvidado a don Gastón, y la noticia de enfermedad tan deshonrosa le había arrancado toda fascinación». ${ }^{217}$

\footnotetext{
212 Ib., pp. 119-120.

213 Ib., pp. 158-159.

214 Ib., p. 220.

215 Ib., p. 228.

216 Ib., p. 233.

217 Ib., p. 247. Antes cfr. p. 242: «La misma noche, don Gastón fue llevado de urgencia al hospital y, desde allí, algún día después, al sanatorio de Arco, junto al lago de Garda. No sé cómo pudo haber brotado tan de repente una enfermedad tan fea, y deshonrosa para
} 
El tono y las imágenes recuerdan, tal vez, cierta comedia a la italiana, su ambiente grotesco, sus finales amargos (la película de Carlo Mazzacurati, de 1989, está lejos de esos registros y elabora un drama íntimo y puro); por no hablar de expresiones regionales que se remontan al mundo de Fogazzaro, matizado por Comisso, y que difuminan —más que acentúan- el drama, incluso en su momento cumbre: el destino y la muerte de Cena, primero en el reformatorio y luego en el hospital. Durante la fuga de aquel acaba bajo el camión que le ayudó a alejarse, con el resultado de una pierna amputada y una gangrena imparable: «iHostia, hostia! ¡Qué daño, Sergio! [...] ¿Has visto cómo me he escapado? [...]. ¡Con una pierna sola se pide caridad mejor!».218

Cómo no pensar en Parise y sus Guerre politiche (Guerras políticas) (1976). Entre 1967 y 1968, en el umbral de los cuarenta, viaja «en medio de guerras y revoluciones» como enviado especial de L'Espresso y Corriere della Sera a Vietnam, Biafra, Laos, Chile, reflexionando sobre la suerte de los muchachos, sobre la guerra de los niños, de quince y dieciséis años. La atención a este dato atraviesa su literatura desde el principio, también El sacerdote guapo, llegando a una fractura insalvable, como se lee en la "Advertencia» (fechada en diciembre de 1975) de ese libro: «Entonces me sentía un muchacho, aunque ya no lo era. Ahora no lo soy, definitivamente. Los viajes, y sobre todo las guerras, envejecen». Incluso los viajes y las guerras más distantes, a los que se vuelve con el recuerdo, en la madurez:

Escribiendo, pensando y mirando con enorme atención lo que le rodea y alguna vez, casi siempre, sufriendo por la imposibilidad de cambiarlo (las únicas cosas que sabe hacer de verdad), el escritor que viaja termina por hacerse una idea propia de lugares y personas distintos [...]. La juventud le ayuda a mirar, porque el ojo, la mente y el corazón son fuertes y resistentes incluso a los grandes dolores de la humanidad. Más adelante, en la madurez, el escritor tiende a reflexionar, a recordar y a ver, como se suele decir, "con perspectiva" los viajes de su juventud. Si es un escritor italiano, que escribe en lengua ita-

la gente ignorante del barrio, en un físico aparentemente robusto. El hecho es que el médico le encontró una lesión donde primero había solo una sombra, tan grave que habría sido necesario operar y, con toda probabilidad, extirparle un pulmón». Sobre la tisis, fascinante enfermedad romántica y luego, en la transición del siglo XIX al XX, un dato patológico más controvertido y ambiguo, permítaseme remitir a Luciano Curreri, «Seduzione e malattia nella narrativa italiana postunitaria», Otto/Novecento, 3-4, 1992, pp. 53-78.

218 Parise, Il prete bello, cit., p. 250. Cfr. por entero el capítulo final, XV: pp. 247-251. 
liana, sabe cuán poca cosa es todo lo que ha visto y contado: en parte porque sus informaciones, aunque sean preciosísimas (no es mi caso), quedan en familia [...]. Porque, en fin, lo quiera o no, de todos modos será siempre, cada día más, un escritor colonial. Sabido y dicho esto, siempre le quedará viajar, vivir y escribir dentro de su colonia que, a pesar de todo, es todavía una de las más bellas, vivas y trágicas del mundo». ${ }^{219}$

Desde una isla de esa trágica colonia, colonia de la colonia, pasaporte para aquel imperialismo romano que Mussolini quería relanzar en el Mediterráneo (y no solo), tiende también a reflexionar, a recordar y a ver "con perspectiva» los viajes de su juventud Giuseppe Dessí, que pertenece a la generación de Delfini y Vittorini; más joven, por tanto, que Parise (veinte años, para ser exactos).

Pienso en Los gorriones, de 1955: ${ }^{220}$ una ausencia, la del hijo del conde Scarbo, que muere combatiendo contra los falangistas de Franco, y un cajón-caja fuerte, con su contenido, que viaja por el mundo en guerra:

Ella siempre estaba a punto de decir que sí, que un beso se lo había dado el sobrino del conde Scarbo, ese muchacho que el conde había acogido como un hijo, después de que el verdadero hubiera muerto en España.

Se trataba de uno de aquellos cajones de ordenanza que empleaban los oficiales durante la guerra de Libia. Lo había comprado [el conde Scarbo] Lo había comprado precisamente en 1911, en Nápoles, antes de embarcarse —es más, había comprado dos iguales, y ambos le habían seguido durante aquella primera campaña, así como en sus viajes por Europa, hasta Bélgica, donde había conocido a su primera mujer, Josefina de la Haye, y luego, de nuevo, en África, donde había vuelto con ella, hasta el Congo; luego, otra vez en Europa, en tiempos de la Gran Guerra, donde una de las dos se había desintegrado por efecto de un obús del 149. La superviviente, como caja fuerte tenía una función, más que nada, simbólica. [...]. En su vida de nómada, el conde había tomado por costumbre encerrar dentro todo lo más precioso que tenía, documentos o dinero.

[...] Fue cuando Giacomo, herido la primera vez, había sido trasladado desde Espańa, donde combatía en las Brigadas Internacionales, hasta la frontera francesa. Entonces, por medio del doctor Cabruno, que le mantenía informado de los movimientos del hijo, al que no podía escribir directamente y del que no recibía directamente noticias, [el conde Scarbo] había mandado el contenido entero del cajón. Era una discreta suma. [...]. Giacomo, que no había cursado estudios regulares, pues se presentaba por libre a los

219 Goffredo Parise, advertencia a Guerre politiche. Vietnam, Biafra, Laos, Cile, col. Struzzi, Einaudi, Turín, 1976, pp. VI, VIII y IX.

220 Giuseppe Dessí, I passeri, Nistri-Lischi, Pisa, 1955. 
exámenes finales, había viajado y gozado siempre de la máxima libertad. De ese modo, su padre gastaba en él cada año la casi totalidad de las rentas de su patrimonio; es más, los gastos no dejaban de aumentar de ańo en ańo hasta que el joven, de repente, abandonada la universidad: se había alistado para ir a combatir contra los falangistas de Franco. Desde entonces, mensualmente, el conde apartaba el dinero que ya no podía mandarle. Vaciado el cajón, cuando Cabruno le dijo que lo habían llevado herido a los Pirineos (o a Francia, no se sabía bien), comenzó como al principio. Su único pensamiento era acumular para el hijo todo lo que podía. Le habían dicho que había muerto, pero él no lo creía. ¡Qué cosas no habían dicho de Giacomo! No le habían ahorrado siquiera la infamia de traidor. Antes bien, para algunos había sido solo un traidor, porque había ido a combatir contra sus mismos hermanos, decían. Otros insinuaban que se hubiera pasado a los fascistas y que, tras muchas peripecias, había cambiado de nombre para acabar en Argentina, donde habría hecho fortuna. Todo lo que era posible imaginar y decir se había dicho de él, así como lo más simple: que había muerto combatiendo al lado de sus compañeros. Pero el conde tampoco aceptaba esta sencilla versión. Se decía que había muerto, sí, pero ninguno lo había visto caer. Por eso apartaba el dinero, y de vez en cuando lo contaba.

[...] Todo lo que acaecía en torno a él [el conde Scarbo], el mundo circunstante, interesaba sobre todo a los demás; a él, indirectamente, y solo por el hecho de que ese era también el mundo en el que Giacomo había vivido y al que algún día tendría que volver. Se veía a menudo, pues, considerando las cosas desde este punto de vista que nadie sospechaba, es decir, en función de la vuelta del hijo — de su hipotética vuelta—. Guerras, revoluciones, conjuras de palacio y caídas de regímenes, rehabilitaciones de hombres considerados réprobos por los poderosos de ayer, catástrofes y reconstrucciones, todo lo que había sucedido y estaba sucediendo tenía para él solo una importancia condicionada e hipotética. ${ }^{221}$

En la «fragmentación del texto narrativo» que caracteriza Los gorriones - como sugería Anna Dolfi en 1977-222 y «en la soledad del pueblo, en la sutil, penetrante distancia de la guerra», referencias no tan alejadas de las utilizadas por Parise en El sacerdote guapo, «las piernas rotas del adolescente Giacomo se funden, saltando el tiempo, con las piernas fracturadas del joven teniente caído en España al lado de las Brigadas Internacionales; la libertad y el destino, la contingencia y las circunstancias, la vida y la muerte se representan en lugares distintos, pero casi fuera de la cronología». Porque «el tiempo no es parámetro de verdad,

\section{Ib., pp. 35, 73-74 y 76-79.}

222 Anna Dolfi, «Il frammentarsi del testo narrativo: I passeri», en La parola e il tempo. Saggio su Giuseppe Dessí, Nuovedizioni Enrico Vallecchi, Florencia, 1977, pp. 380 y 384. Cfr. ahora la nueva edición: La parola e il tempo. Giuseppe Dessi e l'ontogenesi di un "roman philosophique», Bulzoni, Roma, 2004. 
sino instrumento de búsqueda», ${ }^{223}$ sigue diciendo Dolfi a propósito de Dessí; y Parise, en la citada "Advertencia» de 1975, da cuenta sobre todo de aquellos «lugares distintos» y de este instrumento en clave íntima, con el paso, "toda una autoeducación», 224 de la juventud - muchacho solidario con Sergio, Cena y otros muchachos del mundo- a la madurez y la vejez. ${ }^{225}$

Con semejante concepción del tiempo, que presenta un ambiguo desdoblamiento entre padre-viejo e hijo-joven, entre una presencia y una ausencia, y llegados casi al fracaso, anunciado por Vittorini en Diario público (1957), de la transmisión de experiencia de padres a hijos y de viejos a jóvenes, es significativo que Los gorriones (1955), que vuelven sobre la Guerra de España con estas estrategias narrativas, anticipen también - a mitad de los años cuarenta y desde la «doliente Cerdeña», la trágica colonia- un «lugar distinto» y un contexto histórico-geográfico "de subdesarrollo, miseria, dolor y sumisión», como el expresado por Carlos Fuentes en La muerte de Artemio Cruz (1962); con "la muerte del hijo y la que sufre, vive y narra el padre, ya anciano, que no deja de pensar en el joven lejos de casa, en la guerra, y vuelve a ver, a reconstruir, su fin». ${ }^{226}$

En la segunda mitad de los años cincuenta vuelve, «reelaborado», el ciclo de Los hermanos Rupe, de Leonida Rèpaci, nacido en 1898 y, por tanto, de la generación de Francesco Fausto Nitti y su horizonte político. Consta de tres volúmenes: I fratelli Rupe (Los hermanos Rupe) (1932), Potenza dei fratelli Rupe (Poderío de los hermanos Rupe) (1934) y Passione dei fratelli Rupe (Pasión de los hermanos Rupe) (1937), publicados todos por Ceschina, de Milán, y en 1957 se convierte en Storia dei fratelli Rupe (Historia de los hermanos Rupe), editada por Mondadori en su colección Omnibus. Pero es en el cuarto y último volumen de la historia

223 Dolfi, La parola e il tempo. Saggio su Giuseppe Dessí, cit., p. 20

224 Vittorini, Diario in pubblico, cit., p. 213.

225 En clave íntima y menos pública a partir, si se quiere, de la extrema y honesta consideración de que las compilaciones de escritos de viaje, por muy alabadas que hayan sido por los críticos y sin que reniegue de ellas su autor, «tienen el valor de la fecha que llevan». Cfr. una vez más Parise, advertencia a Guerre politiche. Vietnam, Biafra, Laos, Cile, cit., p. VI.

226 Dolfi, La parola e il tempo. Saggio su Giuseppe Dessí, cit., pp. 20-21. 
de los Rupe, disponible en 1968 también en Mondadori, cuando encontramos a Cino en Espańa dando conferencias y dirigiendo, en Madrid, la radio durante la guerra civil, hasta morir bajo un terrible bombardeo fascista. El tejido novelesco está trufado de extractos documentales relativos a la participación de la Italia mussoliniana en la guerra española en apoyo de Franco y de diarios y relaciones de viaje: de Italia a Francia, España y la Argentina recordada en Los gorriones de Dessí.

Comparándolo con los volúmenes precedentes, Arrigo Bongiorno da un juicio negativo - al contrario que Giuseppe Pederiali- del libro, que saldrá por Mondadori en 1973 con el título La terra può finire (La tierra puede acabarse), después de Principio di secolo (Comienzo de siglo) (1969), Tra guerra e rivoluzione (Entre guerra y revolución) (1969) y Sotto la dittatura (Bajo la dictadura) (1973). Estos libros, reeditados sobre todo por la clara fama del autor, no aportan nada nuevo al periodo posantimonio que nos aprestamos a recorrer.

De hecho, Los hermanos Rupe vienen de lejos, de los años treinta antes que de los cincuenta, y sobre todo fuerzan y casi aíslan la novela «meridionalista»* en la superioridad intelectual y moral (también sexual) de los Rupe - o sea, en la hagiografía de un clan calabrés de la burguesía media terrateniente- $-\mathrm{y}$ en la excesiva reconstrucción documental, el ensayo histórico, a veces improvisado, y el panfleto, perdiendo de vista a menudo el discurso narrativo, ingenuo o presuntuoso, de un autor que - como dice Bongiorno- - «se hace prolijo, en la errónea convicción de estar escribiendo una gran novela histórica». ${ }^{227}$

\section{Después de El antimonio. Una rápida incursión}

¿Y después de El antimonio? La guerra civil española parece desaparecer en el atractivo boom de los ańos sesenta, que absolutiza la «dulzura del momento", como diría el Sciascia de El soldado Seis; en las ilusiones que nutren un periodo de transición hacia los «años de plomo» primero, y

* Véase N. de los T. en p. 141.

227 Cfr. Annalisa Gimmi, Il mestiere di leggere. La narrativa italiana nei pareri di lettura della Mondadori (1950-1971), Il Saggiatore/Fundación Arnoldo y Alberto Mondadori, Milán, 2002, pp. 226-227. 
luego, con el dramático punto de inflexión del verano de la masacre, ${ }^{*}$ hacia la despolitización de los años ochenta. Solo los años noventa, por efecto de la caída del muro de Berlín (1961-1989) y del exitoso resurgimiento del fascismo en el gobierno italiano, comenzarán a redefinir ese contexto.

En cualquier caso, siguiendo las huellas de una suerte de transición italiana a lo largo de los años sesenta y setenta, en un periodo posantimonio, hallamos algunos senderos narrativos en la novela, incluyendo la de consumo, popular, y en los diarios, de una prosa más refinada: van del éxito inmediato al valor testimonial, con redescubrimientos más o menos tardíos y marginales. Pienso en Davide Lajolo y Alberto Bevilacqua, por un lado, y en Joyce Lussu y Vittorio Bodini, por otro.

En cuanto a novela popular, pensemos en Una città in amore (Una ciudad enamorada), de Alberto Bevilacqua, publicada en 1962, auténtico debut novelesco tras la colección de relatos La polvere sull'erba (Polvo sobre la hierba) $(1955)^{228}$ y antes de La Califfa (1964). ${ }^{229}$ Bevilacqua pone en escena los primeros cincuenta años del siglo XX en menos de doscientas páginas, con opciones diametralmente opuestas a los Rupe de Rèpaci, también por su voluntad de adherirse a un microcosmos, el de la Parma vieja y algunos de sus barrios y personajes, reales, como Guido Picelli, del que informa la breve "Nota» al final de la novela, pero simbólicos «en la proyección mítica, fantástica, de aquellos que vivieron y lucharon» por la libertad: «Picelli tal y como lo recuerdan todavía hoy en algunos barrios de la Parma vieja». ${ }^{230}$

$\mathrm{Al}$ comienzo del octavo y último capítulo, titulado "José», ${ }^{231}$ el más denso y, sin duda, el más interesante de la novela, y antes del rápido «Epílogo» surge en la girándula de figuras más o menos extravagantes, un personaje escindido entre lo público y lo privado, entre una aparente altane-

* N. de los T.: El atentado neofascista en la estación de tren de Bolonia del 2 de agosto de 1980 fue el punto culminante de la denominada «estrategia de la tensión».

228 Alberto Bevilacqua, La polvere sull'erba, Sciascia, Caltanisetta, 1955.

229 Alberto Bevilacqua, La Califfa, Rizzoli, Milán, 1964 (La califfa, trad. Vicente Villacampa, Noguer, Barcelona, 1981).

230 Volverá a hablar de ello Cacucci en el trabajo dedicado a Modotti (1988 y 1991), así como en Oltretorrente (2003). Cfr. Alberto Bevilacqua, Una città in amore, Sugar, Milán, 1962 (reed. Rizzoli, Milán, 1970, y col. Oscar, Mondadori, Milán, 1990 y 2001, p. 176).

231 Ib., pp. 149-173. 
ría e íntimas laceraciones que hace de España no una ampliación de Sicilia, a la manera de Sciascia, sino «otro lugar» emiliano y romañolo; «otro lugar» que nos trae a la mente la boutade de El camarada don Camilo (1965) ya comentada, especialmente en relación con la presencia de Franco, dictador "que no se ve» pero que todavía es fuerte y "apesta a cura»:

José mandaba una postal desde Madrid, cada ańo, cuando venía el buen tiempo. Bordino se encontraba en las manos aquellas vistas translúcidas de las Bodegas o de la plaza Mayor. [...]. Detrás de las postales ponía: «Llegaré dentro de tres días. Venid a recogerme a la estación. Saludos. José». Pocas líneas que tenían el poder de armar un revuelo en toda la casa, porque Bordino, contagiando a los demás, suscitaba reacciones e impaciencias que crecían con el paso de los días.

Cada año, por consiguiente, se volvía a poner en discusión la personalidad del extraño amigo de Bordino. Mi madre no quería atender a razones y decía: «Está loco!», añadiendo que José se había hecho rico no tanto — como sostenía él- vendiendo chorriso cuanto extorsionando oportunamente a la gente pobre. «iNo es verdad, son habladurías infames!», saltaba Ailè, según el cual José era, al contrario, un puro idealista que pagaba también con esas maledicencias el hecho de haber ido siempre contra corriente cuando era necesario.

Pero la verdad, quizá, estaba a medio camino. Aventurero, en efecto, el falso espańol lo era o, mejor, lo había sido. Bastaba mirarlo fijamente bajo los párpados extenuados, donde la luz estaba al acecho, siempre en guardia, para aferrar la desconfianza y el pasado turbulento.

Romańolo empedernido, anarquista pero egoísta, antifascista pero dictador en cada decisión de su vida, José se había marchado a los treinta ańos a la Guerra de Espańa, contra Franco, y en España se había quedado, cambiándose incluso el nombre, a pesar de las amenazas y las represalias. "Al final, ¿qué diferencia hay?», decía. «España es como Emilia, como Romańa... La misma sangre, la misma gente, la misma poesía».

En fin, la inminente llegada de José despertaba a Bordino. [...]. Bordino se levantaba al alba, ponía en pie a toda la casa con sus quejumbrosas blasfemias [...] Llegado a la estación, [...] se apretaba con todas sus fuerzas al cuerpo gigantesco del amigo.

Sosteniéndolo, José se adelantaba. [...]. Ailè rompía el hielo: «¿Y Franco? ¿Y España?», mientras Bordino asentía a las preguntas. José arrastraba a los dos amigos hacia la salida, sacudiendo la cabeza. «iMierda!», respondía. «iLa misma mierda de siempre!... Franco es un tirano de aúpa precisamente porque no se ve. Si se quitase las insignias de la Falange, nadie diría que está ahí. Y en cambio está, ya lo creo, y lo que es peor, apesta a cura». Bordino lo perseguía. «Y en cuanto a mujeres...", proseguía José, y se volvía a buscar el hombro de su viejo camarada para palmearlo. «Eh, Bordino... henos aquí, dispuestos como en los viejos tiempos». 232

Pero José no «bajaba a Parma cada vez que venía el buen tiempo» por las mujeres o, como reza el título del sexto capítulo, por las "putas de mi

232 Ib., pp. 149-151. 
corazón». Tras la osadía, la altanería de José y de otros hombres, típica de las novelas de Bevilacqua, hay un dolor íntimo, ligado a la guerra civil espańola, que el texto no tarda en desvelar.

Una vez dejadas las maletas en la consigna, se encaminaban hacia el corazón de la ciudad y, mientras José abría la fila, [...] Ailè pensaba en la historia que empujaba cada ańo a aquel «bandido nostálgico» — como le llamaba mi madre- a volver a Parma, a ver de nuevo la ciudad, barrio por barrio, a abrazar otra vez a Bordino y, sobre todo, a visitar como un lugar sagrado la casa de Amelia Sampieri, ya a las puertas de la muerte.

La colina que domina Barcelona, cortada a pico sobre un mar pálido, es una colina-cementerio; en la maraña de plantas amarillas y verdes, [...] lápidas pequeñas como mojones, hincadas sobre las sepulturas de los pobres. Sobre una de esas lápidas aparece escrito: «Diputado italiano antifascista muerto por la libertad de España». Pero la inscripción está casi totalmente borrada y hay quien pasa, muy a menudo, para ensuciarla y profanarla. Guido está sepultado allá abajo, entre las tumbas de los descargadores de la Puerta del Sol. Desde el 38, solo José sube a arrancar las malas hierbas y a limpiar el mármol de las porquerías esparcidas por la noche, con metódica obstinación, aún hoy. José se sienta al borde del mármol y llora cada vez. Tiene la pistola cargada metida entre la chaqueta, pero nunca ha podido coger in fraganti a los ultrajadores.

Cuando se ha desahogado, [...] recuerda sus años jóvenes y la muerte de su compañero. Guido murió atacando El Matorral, empujando a los voluntarios del batallón Garibaldi hacia Aragosa y el Cerro del Águila: la bala de un franquista, acertándole en la boca, le hizo rodar cuesta abajo, a los pies de José y entre los uniformes de los polacos de la Dombrowsky, cuando la posición había sido casi conquistada.

[...] Guido había llegado a Albacete algo antes, como un fugitivo, tras haber sido obligado a dejar para siempre Italia y su ciudad, con aquel poco de vida que había logrado volver a poner en pie (Amelia le había visto partir con la mirada de los días mejores, a pesar de todo. [...]. Entre amigos silenciosos, agrupados en un rincón, en torno a Bordino, con la garganta hecha un nudo, Guido había subido al vagón gritando «hasta pronto» y, cuando había sonado el silbato y el tren había dado el primer tirón, ella, para no verlo marcharse, no obstante las llamadas de los otros, se había encaminado al pasaje subterráneo, rozando la pared como si la culpa hubiese sido suya).

[...] Después, con las primeras luces del alba, cuesta arriba corriendo por El Matorral...

"Ve a Parma», había murmurado Guido, con la cabeza ensangrentada entre las rodillas de José, «y dile a Amelia que tenía razón... que la política... que tenía que haber estado más cerca de ella, y que lo siento. Al final de todo, no me siento más que solo».

Por eso José bajaba a Parma cada vez que venía el buen tiempo. Cada primavera, desde el 38, el rito de costumbre, sin variación, [...] los claveles para Amelia y luego... ${ }^{233}$

233 Ib., pp. 152-156. 
Y Amelia, que se está muriendo y encima quieren arrebatarle la casa, es el personaje que entona el nostálgico y político canto final de la novela de la vieja Parma y de "Parma la roja». ${ }^{234}$ "Una vez hubo amor en esta ciudad, pero ahora...»: "La revolución, el fascismo, la Guerra de España. [...]. Vosotros decís ahora "abajo los fascistas", "Mussolini era un loco", pero es fácil decirlo ahora. Nosotros lo dijimos cuando él era duce, y a cara descubierta...». 235

Guido Picelli, con nombre y apellido, aun intuidos «en la proyección mítica, fantástica, de los que vivieron y lucharon a su lado», ${ }^{236}$ se aleja del héroe sciasciano de El antimonio (1960), que no tiene nombre. El nuevo soldado desconocido de Sciascia, como decíamos en el capítulo primero, no está bautizado y por eso sobrevive, huyendo de la retórica de los caídos y los supervivientes. El soldado Seis también ayuda a Sciascia en este sentido. El personaje real, en cambio, es una trampa, por muy filtrada que esté por una novela "coral», eficaz a su manera.

En el fondo es lo que le sucede a Davide Lajolo y su novela popular, comenzando por Il "voltagabbana» (El chaquetero) (1963), ${ }^{237}$ texto del que "'masivamente" [...] emerge la figura de Francesco Scotti». "Novela de formación, "novela-verdad", novela-reportaje, en ella se desarrollan las vidas paralelas del protagonista, "chico del pueblo, hijo de campesinos, crecido en años de escasez, privado de instrumentos críticos y de puntos de referencia” (y aquí hay un fuerte componente autobiográfico) — desde su inicial adhesión al fascismo y la consiguiente participación en las columnas de Mussolini enviadas a la guerra civil española hasta la elección de la libertad y la liberación al sumarse a la resistencia- y de Francesco Scotti, que habría visto en seguida el "buen camino" ». ${ }^{238}$

234 Ib., p. 172.

235 Ib., pp. 163-164. Cfr. también la p. 165: «Y luego el epílogo: Lampedusa, Lipari, la cárcel de Messina, la expatriación en Francia y en Rusia, y, al final, España, con esas cartas de Guido. [...]. Pero cuando llegaba a estos momentos de su vida, Amelia meneaba la cabeza y decía: «№, basta, no quiero seguir pensando!».

236 Ib., p. 176. Cfr. Alberto Bevilacqua, Lui che ti tradiva, Mondadori, Milán, 2006.

237 Davide Lajolo, Il voltagabbana, Mondadori, Milán, 1963; reed. en col. BUR, Rizzoli, Milán, 1981, introd. de Giorgio Bocca.

238 Amedeo Anelli, "Dal romanzo alla vita. Il Voltagabbana e Francesco Scotti», Il Lodigiano (sección «Le tradizioni invisibili», 20), 14 de febrero de 2003, p. 23. Pero cfr. 
De este modo nos alejamos cada vez más del horizonte sciasciano. La urgencia por identificar el «buen camino» —y por seguirlo aun considerándose, con ironía pero también con ligereza, un «chaquetero» o, mejor, como los «italianos habituados a vestir la chaqueta del que paga»— ${ }^{239}$ sería el final del recorrido, el paradójico agotamiento, pese al «fuerte componente autobiográfico", de la autobiografía de la nación, que vacila entre el coraje y la desilusión, en una historia hecha siempre por otros, sufrida, nunca realmente «a la medida humana» — bastaría un simple «Quiero ver cosas nuevas». ${ }^{240}$

A propósito de la historia sufrida, sobre la que vuelve Lajolo en Veder l'erba dalla parte della radici (Ver la hierba del lado de las raíces) (1977), ${ }^{241}$ haciéndola más radical y sombría, menos irónica, será útil citar algún pasaje de la novela de 1963, especialmente en relación con el «destino desconocido", para aproximarla luego a fragmentos de la novela posterior, a propósito del reclutamiento oculto:

Pasé la noche pensando. Todas las palabras que le había dicho a mi madre, para consolarla y ahuyentar sus miedos, cuando eché la solicitud para la guerra de África, todos los razonamientos con mi padre [...] ahora me parecían retóricos y falsos.

Me vi en uniforme, entre caras nuevas, en una ciudad nueva. «Destino desconocido», habían escrito en el telegrama. [...]. Lo intuía: «Destino desconocido» quería decir ir a la guerra.

Otro telegrama: la partida había sido retrasada veinticinco días. Quien debía marchar, en cambio, aquel mismo día era él, el secretario del ayuntamiento [Bovio] [...], a España a combatir contra los bolcheviques.

[...] Le miré y le cogí una mano. Él me abrazó.

— Te pido un favor - me dijo despegándose en seguida, como si se avergonzara-, acompáńame a casa para decírselo a los míos. ¿Sabes?, soy hijo único y mi madre sufre del corazón; para ella podría ser un golpe demasiado fuerte. Tú me ayudarás a prepararla. Y sabiendo que también tú vendrás donde voy yo, se convencerá un poco».

—¿Dónde?

-A Espańa. Se lo he preguntado al comandante del puesto de mando, cuando me transmitió la orden por teléfono: «destino desconocido» quiere decir España.

-Pero yo pertenezco al ejército y tú a la milicia. Esa es una guerra fascista.

Davide Lajolo, Bocche di donne e di fucili, Barulli, Osimo, 1939, introd. del general Annibale Bergonzoli, y Massimiliano Griner, I ragazzi del '36. L'avventura dei fascisti italiani nella guerra civile spagnola, Rizzoli, Milán, 2006, pp. 169-179.

239 Giorgio Bocca, introd. a Lajolo, Il voltagabbana, cit., p. 9.

240 Sciascia, L'antimonio, cit., p. 230.

241 Davide Lajolo, Veder l'erba dalla parte delle radici, Rizzoli, Milán, 1977. 

España.

—El comandante me ha asegurado que «destino desconocido» significa

$[\ldots]$

— ¿Solicitud? Yo hice una sola solicitud, para ir a combatir a Abisinia. Ninguna otra. te de campo.

—Es la misma que sirve para las dos — sentenció con ironía el ayudantono.

[...] El ayudante debía de haberme comprendido porque cambió el

[...] -Estos son tiempos duros para todos. Con el sueldo ya no se vive, sobre todo si, como me pasa a mí, se tiene una familia que mantener. Así que ponen la firma al pie de un impreso de voluntario hasta los que peinan canas. ¿Sabe qué es lo que opino yo, personalmente? Que al final nos desviarán precisamente hacia África, como batallones de trabajo. Los soldados que componen nuestros dos regimientos son todos, de hecho, voluntarios para batallones de trabajo. Los más jóvenes son de la quinta de 1910, ¡figúrese! ¿¿Dónde quiere que los manden? La mayor parte son desempleados de Sicilia y de Calabria.

— ¿Desempleados? -interrumpí.

-Claro, esta es la división de los desempleados; llevan el fusil, pero esperan ir a manejar la pala para hacer carreteras. De todos modos, ya tendrá ocasión de informarse mejor. Creo que todavía permaneceremos bastante tiempo en este barro de Littoria, ${ }^{*}$ porque la división, desde mañana, estará ocupada rodando una película. Sí, actuaremos de comparsa: masas, como dijo el otro día su director, de Escipión el Africano".

Me quedé pasmado. ¿Para eso me habían reclamado?242

Y llegamos a Escipión el Africano (1937), recientemente recordado por Carlo Lucarelli en Guernica (1996), ${ }^{243}$ gracias quizá a El chaquetero de Lajolo, lectura posible para el joven autor, nacido en 1960. Llegamos a esa mezcla de ironía y estupor que la historia, antes que la literatura y el cine, ha proporcionado a manos llenas, como decíamos al rastrear las concatenaciones que, entre los ańos treinta y sesenta, produce el imaginario del peplum en Sighinolfi, la comedia a la italiana en Jovine. El riesgo de esta fácil mezcla, exorcizante y amarga, consiste en agotar la autobiografía de la nación, reiterándola y fijándola en tópicos que la vacían de sentido, de significado, y la reducen más y más a un juego complaciente, autosatisfecho, con las propias desilusiones, a un divertimento que es fin en sí mismo para las nuevas generaciones. Siendo cada vez más difícil crear para ellas una nueva autobiografía de la nación, con su correspondiente idea de la

* N. de los T.: Provincia inaugurada por Mussolini en 1932 dentro de la región del Lacio, sobre los pantanos palúdicos del Agro Pontino. Desde 1946 se llama Latina.

242 Lajolo, Il voltagabbana, cit., pp. 41-44.

243 Carlo Lucarelli, Guernica, cit., p. 39. 
literatura, incluso partiendo de un hecho tan fuerte y cargado de sentido como la guerra civil española. ${ }^{244}$

Desde esta perspectiva, Ver la hierba del lado de las raíces (1977) — título logrado para una novela que, aunque premiada en Viareggio, quizá no lo es tanto- vuelve a los voluntarios del sur en paro, calabreses, sículos, al hablar de las víctimas del reclutamiento oculto que no quieren hacer la guerra, sino cultivar la tierra, y que tienen una buena relación con los campesinos españoles.

Los viejos campesinos españoles [... sabían a esas alturas que aquellos italianos eran todos gente de la tierra, braceros. Los encuentros se hacían cada vez más espontáneos, discutían de las miserias comunes. La mayor parte de los soldados confiaban en que no habían sido movilizados para combatir. Habían echado la solicitud para trabajar la tierra en África, con la esperanza de poder hacerse con una hacienda. No querían hacer daño a ninguno. Llevaban las estrellas de cinco puntas, ${ }^{*}$ no sabían de política, no querían matar ni que les matasen. ${ }^{245}$

En 1967, en la colección Libri del Tempo de editorial Laterza, que once años antes había acogido Las parroquias de Regalpetra, de Sciascia, sale Fronti e frontiere (Frentes y fronteras) de Joyce Lussu, diario «novelado» con diálogos que nos lleva a los años de la Guerra de España y, sobre todo, a los inmediatamente siguientes, con exiliados reales como la autora y Míster Mill, o sea, el escritor Emilio Lussu, capeando las dificultades de la huida. De fronteras habla también, de manera más implícita aunque con una constante atención a España, ${ }^{246}$ Vittorio Bodini. Lo hace, con una refinada prosa narrativa, en La lobbia di Masoliver (El sombrero de Masoliver), editada en 1980 con otras novelas de los años cuarenta y cincuenta pero datable hacia 1968-1969, cercana, por tanto, a la publicación del diario de Joyce Lussu.

Del tercer capítulo de Frentes y fronteras son las páginas que más interesan a nuestra rápida incursión en el periodo posantimonio especialmen-

244 Además de los ensayos arriba citados de Onofri y Jossa, cfr. Stefano Calabrese, L’idea di letteratura in Italia, Bruno Mondadori, Milán, 1999.

* N. de los T.: Distintivo del Ejército italiano.

245 Lajolo, Veder l'erba dalla parte delle radici, cit., p. 43. Para este título cfr. una vez más Sciascia, El antimonio, cit., p. 168: «mejor habría sido estar bajo la tierra, que húmeda se pega a las barbas de las raíces».

246 Vittorio Bodini, Corriere spagnolo (1947-54), ed. Antonio Lucio Giannone, Manni, Lecce, 1987. 
te en relación con lo que diremos en el próximo capítulo a propósito de las huidas de otros exiliados de excepción, como Walter Benjamin en L'angelo della storia (El ángel de la historia) (2001), de Bruno Arpaia. ${ }^{247}$

Salimos de Tolouse a primera hora de la tarde. Hacia la noche llegamos a Banyuls, a los pies de los Pirineos. Llevábamos vestidos de ciudad y solo habíamos cogido una bolsa con zapatos de recambio y víveres para dos días.

Teníamos cita con el guía a las diez de la noche, a las afueras del pueblo. Nos esperaba inmóvil, al lado de un matojo de cañas altas, y apenas nos vio se puso a caminar. Seguimos en silencio la delgada sombra del impermeable gris, que se movía ágil y segura delante de nosotros, por senderos desiertos y luego a lo largo de los andenes; por fin abandonamos la vía y doblamos a la izquierda, monte arriba. La ascensión, en una oscuridad casi total, por entre vińas aterrazadas, era fatigosa. Había empezado a llover. El guía trepaba con rapidez, sin volverse y sin hablar.

[...] El guía se llamaba Francisco y era aragonés; era alto y delgado y su rostro, de nariz sutil y labios estrechos, expresaba una huraña altivez. Había sido oficial del Ejército republicano. Antes de la guerra civil había sido contrabandista.

[...] -España — dijo Francisco gravemente-. Ahora ya no hay más subida, se baja todo el rato. [...] Mirábamos, a la luz menguante, la fértil llanura española, con pensamientos encontrados y profundos sentimientos. ${ }^{248}$

Tras hacer una peligrosa parada en Barcelona, con su correspondiente interrogatorio en comisaría, Emilio y Joyce, con un nuevo guía menos de fiar, Carmelo, llegan a Badajoz, «pintoresca ciudad de murallones medievales» donde por contraste emerge, a través de las palabras de Joaquina, «amable criatura», el recuerdo de la guerra - que "no» ha sido una "guerra civil»— y las masacres cometidas allí por los marroquíes; con la complicidad de la policía portuguesa, que devolvía a España a los republicanos que huían a Portugal (policía y país que reencontraremos, como apoyo de Franco, en Sostiene Pereira [1994], ${ }^{249}$ de Tabucchi):

Joaquina nos habló [...] de la guerra civil, que en Badajoz había sido muy sangrienta. Fue la primera ciudad asaltada por los marroquíes de Franco, cuando la resistencia republicana no estaba todavía organizada. Habían entrado en la ciudad degollando a sus defensores, casi desarmados, con aquellos cuchillazos, y habían cometido atrocidades inauditas. Ocho mil personas,

247 Bruno Arpaia, L'angelo della storia, Guanda, Parma, 2001.

248 Joyce Lussu, Fronti e frontiere, col. Libri del tempo, Laterza, Roma-Bari, 1967, pp. 35-37.

249 Antonio Tabucchi, Sostiene Pereira, Feltrinelli, Milán, 1994 (Sostiene Pereira, trad. Carlos Gumpert y Javier González, Anagrama, Barcelona, 2003). 
entre obreros y gente del pueblo, encerradas en la plaza, allí, en la plaza por donde habéis pasado, y masacrados todos con las ametralladoras. Solo a la mańana siguiente la población, horrorizada, había podido recoger y componer un poco los cadáveres para sepultarlos. Ah, qué horror, la guerra - no guerra civil, porque Franco ganó solo gracias a la fuerza de los mercenarios extranjeros- Los republicanos supervivientes se echaron al maquis (algunos intentaron pasar a Portugal, pero la policía portuguesa los devolvía a Espańa) y Joaquina estaba entre las numerosas mujeres y muchachas animosas que iban a reaprovisionarles con víveres y ropa. Poco a poco, muchos volvieron silenciosamente a la ciudad, esperando, la venganza en el corazón. ba por los ojos.

—Llegará el día, llegará — decía Joaquina, y un relámpago de ira le pasami país.

—Mata más la lengua que la espada — dijo Lussu—. Al menos, así es en sacó dos pistolas. ${ }^{250}$

En 1980, como decíamos, sale una colección de narraciones de Vittorio Bodini. En el texto final, un inédito que se remonta a los años 1968-1969 y brinda título al volumen editado por Scheiwiller, El sombrero de Masoliver, parece agitarse, como un fantasma, el recuerdo de la guerra civil, ciertamente evocado en tiempos más fáciles («en una montaña con un taxi») pero en una triste localidad fronteriza, Port Bou, que tendremos ocasión de volver a citar a propósito de El ángel de la historia (2001):

Así que salí una noche, como por otro lado hacía a menudo [...] si eran más de las cuatro de la noche, se oía el canto airado de los gallos como un pelotón de soldados rebeldes... Salí con el cuerpo profundamente masacrado, sobre todo el bazo, cansado de sus aspavientos, de sus saltos, de sus arrebatos.

Así que me acordé de Port Bou, que ahora vería otra vez: una gran estación de tejas rojas, detrás de la cual uno cree que haya un pueblo, y en cambio sube luego a una montańa con un taxi y, desde allí, ve de nuevo Port Bou, que es solamente esa estación de tejas rojas que hacen parecer azulados los montes grises. Detrás no hay nada, exceptuando quizá alguien que vende plátanos a todos los viajeros que pasan a Francia. Pero no pueden dejarnos así, en una estación vacía, como si no hubiera pasado nada. Entonces aparecen los tricornios de dos guardias civiles sobre la cima de la montaña, pero no añaden nada a aquel vacío, como cuando tras un adiós se añade todavía una frase y no sirve para nada, porque nos dejamos de todas maneras, solo que además hemos perdido la entereza. ${ }^{251}$

250 Lussu, Fronti e frontiere, cit., pp. 40-41.

251 Vittorio Bodini, La lobbia di Masoliver, ed. Paolo Chiarini, Scheiwiller, Milán, 1980, p. 94. 
Después de los años setenta, con las alusiones a la guerra española de Piazza d'Italia (1975) de Tabucchi —al que nos referiremos en el capítulo siguiente- y de Memorie malvage (1976) de Barbara Alberti, la citada Ver la hierba del lado de las raíces (1977), de Lajolo, o Il miliziano spagnolo (El miliciano español) (1979), de Filiberto Amoroso, los años ochenta parecen detenidos en la frontera de Bodini, un microcosmos que oculta casi la guerra y la predispone a otras revisitaciones narrativas, más típicas de los años noventa, como el género negro. Es el caso, me parece, de $L a$ derrota (1982), de Italo Alighiero Chiusano, una suerte de enfrentamiento ético, pero también físico, entre seis hombres de la república y seis hombres de Dios en el ámbito de una "venerable abadía» de los Pirineos, que nos hace pensar en El nombre de la rosa (1980) de Eco, y que dista solo "seis kilómetros de la frontera francesa»: "Qué silencio", pensó don Luciano, volviendo los ojos a las colinas. Quién habría dicho que allá abajo, a algunas decenas de kilómetros, comenzaba esa España ensangrentada de la que hablaba todo el mundo. Parecía un país de ensueño. Y en cambio, allá estaban Barcelona, Madrid, Teruel, barreras de artillería, desembarcos, incendios, sangre por las calles, iglesias profanadas».

Cuanto más se avanza en la narración, más se atenúa el fragor de la guerra, no obstante en la abadía se celebre un proceso republicano contra sacerdotes injustamente acusados de espionaje. Uno de ellos, italiano, joven ambicioso de quien se sospecha si no fue amigo de Mussolini, asume la tarea de esclarecer la derrota colectiva, la del título, en una carta que deja antes de suicidarse y que ruega sea destruida: "A quienes se hacen la guerra en España desde uno y otro frente, no les deseo suerte. Venza quien venza, habrá perdido el hombre, la tolerancia, la decencia, esa poca libertad que ayuda a hacer soportable la vida». ${ }^{252}$

252 En cursiva, en el original. Italo Alighiero Chiusano, La derrota, Rusconi, Milán, 1982, pp. 124, 62, 43-44 y 154. Cfr. Barbara Alberti, Memorie malvage, Marsilio, Venecia, 1976, pp. 83-87, y Filiberto Amoroso, Il miliziano spagnolo, Pan Arte, Florencia, 1979, que, como se explica en la premisa, pp. 7-9, «reescribe» una novela suya, La rinuncia, Trevi, Roma, 1966, porque «en los ańos del llamado "milagro económico" la gente, completamente inmersa en un bienestar material ilusorio, no podía comprender ya a ese personaje [el miliciano español]»y «solo en años más cercanos [la década de los setenta]» se asiste «al brusco despertar» de "ciertas pasiones, ciertos humores, ciertos ideales». 


\section{ENTRE MADRID Y GUERNICA. ACTUALIZACIONES \\ SOBRE LA NARRATIVA ITALIANA, LA GUERRA DE ESPAÑA Y SUS CIUDADES HERIDAS (1991-2006) ${ }^{1}$}

\section{Hoy: límites cronológicos e hipotéticas reseñas entre los siglos XX y XXI}

Hoy — que es el ayer más inmediato, el de los últimos años, a caballo entre 1900 y 2000 - la narrativa italiana empieza a apropriarse, con una desenvoltura que a veces podría parecer excesiva, de la historia y la memoria de la guerra civil espańola; cuyo cincuentenario es detonante en la segunda mitad de los ochenta, de varias iniciativas editoriales de carácter biográfico y narrativo, como I fuochi le ombre il silenzio. La frágil vida di Tina Modotti negli anni delle certezze assolute (1988), de Pino Cacucci,

1 En este capítulo, y en particular su segundo epígrafe, señalamos los traductores — del español, sobre todo, pero también de otros idiomas - de obras y ediciones recientes publicadas en Italia y relativas, en términos más o menos novelescos, a la Guerra de España. Respecto a la versión aparecida en revista (cfr. el epílogo de este libro), he suprimido las fechas de nacimiento y muerte de los escritores italianos y extranjeros citados, por razones de uniformidad. Inicialmente, la idea era la opuesta: extender tales indicaciones a los otros dos capítulos e incluso al índice onomástico, de modo que el lector pudiera orientarse en las intersecciones del pasado con el presente. Al elegir la primera opción, he querido aligerar el razonamiento, especialmente en el texto, evitando el riesgo de un libro considerablemente denso. 
o histórico y político, como prueba un libro de 1987 de la editorial Angeli, al cuidado de Claudio Natoli y Leonardo Rapone. ${ }^{2}$ Ettore Scola, ese mismo año, en el amplio fresco histórico de La familia, hace participar en la guerra civil española al primo Enrico (Giuseppe Cederna), exiliado en París, y en ese conflicto encontrará la muerte. España, mientras, se aproxima un tanto a directores de la comedia italiana de antańo (Todos a casa de Comencini, 1960) con La vaquilla (1985), de Luis García Berlanga, con argumento y guión, datables en los años cincuenta, del mismo Berlanga y Rafael Azcona.

La actitud de ciertos narradores parece nacer de un nuevo interés que, a partir de 1989, surge también, en la Italia de Alleanza Nazionale (marbete definitivo de enero de 1995), de un movimiento más general de reflexión sobre el fascismo (otra "guerra civil»), que incluso se asoma con éxito a la narrativa de consumo, sobre todo en el género noir y el policiaco con tintes de terror, ${ }^{3}$ desde Carlo Lucarelli a Eraldo Baldini, por ejemplo,

2 Cfr. Pino Cacucci, I fuochi le ombre il silenzio. La frágil vida di Tina Modotti negli anni delle certezze assolute, Agalev, Bolonia, 1988, pp. 64-93 (Tina Modotti, trad. Mercedes Corral, Circe, Barcelona, 1992), y Claudio Natoli y Leonardo Rapone (eds.), A cinquant’anni dalla guerra di Spagna, Angeli, Milán, 1987. Cfr. también la atención — nacida en el seno de otros aniversarios, la revolución, la república, la deriva hacia la misma guerra civil_ prestada por Giuliana Di Febo y Claudio Natoli (eds.), Spagna anni trenta. Società, cultura, istituzioni, Angeli, Milán, 1993, libro del que invito a leer la primera parte, introductoria, dedicada al "Debate historiográfico», con intervenciones de Claudio Natoli, Gabriele Ranzato y Enric Ucelay-Da Cal, pp. 15-70, y la nutrida cuarta parte, «Cultura e intelectuales», donde me fijo en José Carlos Mainer, «Los intelectuales y la República», pp. 330-346.

3 A dos o tres lustros de distancia, con la cansina vuelta de las previsibles tramas del policiaco, del terror y géneros afines, los años veinte, treinta y cuarenta del fascismo - especialmente el decenio central- entran también en otras estrategias narrativas, que difuminan su presencia y la enredan en un microcosmos más o menos vivaz, pero sin duda menos gótico y noir, dentro de un pequeño mundo muy frecuentado por la literatura italiana de los siglos XIX y XX, entre el drama y la comedia. Pienso, por ejemplo, en las que pone en juego Andrea Vitali en La figlia del podestà, Garzanti, Milán, 2005 y en Olive comprese, Garzanti, Milán, 2006, con atmósferas a lo Piero Chiara y posibles ecos, aunque transformados casi todos en sentido positivo, de Il piatto piange (1962) y de ciertas prosas que le preceden, las de Dolore del tempo (1959) y, sobre todo, del "cuentismo» que va de La spartizione (1964) a Il pretore di Cuvio (1973). Cfr. a este propósito Giovanni Tesio, Piero Chiara, La Nuova Italia/Il Castoro, Florencia, 1982, pp. 42-48, pp. 62-68, que pone bien a las claras la elección del "pequeño mundo encerrado en un tiempo sin historia» (p. 68), donde «el proprio fascismo, como ya había dado a entender en Il piatto piange, no incide en el fondo ni agita demasiado las aguas; el tiempo, no obstante las aparentes sacudidas y los estancamientos superficiales, va "como antes" o cambia tan lentamente que 
desde Carta bianca (1990) e Indagine non autorizzata (1993) hasta Mal'aria (1998). Aun cuando para el primero la historia se convierta, en el curso de los años noventa, en un ingrediente cada vez más prescindible, y el segundo prefiera el folclore, se trata de todas maneras de narraciones que flirtean con ese escrúpulo histórico-político que emerge, desde luego con más fuerza, justamente a mitad de los noventa, en Tierra y libertad (1995).

Pero el primer film histórico de Ken Loach, al menos formalmente (apariencia y presupuesto más consistentes de lo habitual), parece funcionar mejor en el plano de la actualidad, al cual está vinculado por su estructura narrativa (la nieta reactiva en el presente, contra cuarenta años de Franco, el significado de la lucha antifascista del abuelo). Mientras que, en el plano histórico, resulta en parte anacrónico, especialmente la tesis de la causa revolucionaria traicionada y perdida in toto por los comunistas ortodoxos. $^{4}$

En Italia, la película tuvo buena aceptación y puede haber sido, al discurrir entre pasado y presente, historia y creación, una de las causas del retorno de la guerra civil española. La escritura de Ken Loach y Jim Allen, su guionista, puede haber movido al avispado Lucarelli, y andando el tiempo también a Cacucci, a desarrollar con rapidez parábolas históricoterroríficas y biografías anoveladas más o menos logradas y convincentes: Guernica, de Lucarelli, es de 1996, a mitad de camino entre la reescritura propiamente novelesca y la propuesta, con nuevo título y trama, del trabajo que dedicara a Modotti, Tina (1991); Ribelli (2001) es de Cacucci,

muchos se mueren "en el 38 o en el 39 sin darse cuenta siquiera de que ya todo está en movimiento hacia una época nueva, despojada de la piedad del pasado y malévola contra los mismos signos del tiempo"» (p. 63). Para la reflexión sobre el fascismo, especialmente la República de Salò y sus aledaños, cfr. el libro «rompehielos» de Claudio Pavone, Una guerra civile. Saggio storico sulla moralità nella Resistenza, Bollati Boringhieri, Turín, 1991 y 1994, pp. 221-312 y 678-705.

4 Pienso, sobre todo, en lo que sostiene Gabriele Ranzato, experimentado historiador y especialista en la guerra civil de España, "Loach è "un compagno che sbaglia"», en Dino Audino y Stefanella Ughi (eds.), Ken Loach, pról. Alberto Crespi, col. Script/Lento, Dino Audino Editore, Roma, 1995, p. 61. Véase, en cambio, lo que sugiere un joven novelista como Pino Cacucci, Ribelli!, Serie Bianca, Feltrinelli, Milán, 2001, luego en la col. Universale Economica, 2003, p. 11: "gracias, queridísimo Ken Loach, que con Tierra y libertad has dado voz internacional a los rebeldes aplastados entre dos enormes dispensadores de falsedades históricas: franquistas y estalinistas)». 
quien entre otras cosas pasa en esos años —como Lucarelli, por lo demás - de pequeñas experiencias de publicación a grandes editoriales. Es significativa, creo, en relación con ciertas dinámicas del mercado editorial más que por las implicaciones teóricas y culturales de la querida y compleja "posmodernidad», la llegada de Cacucci a la Feltrinelli, que en 1994 publicaba Sostiene Pereira, de Antonio Tabucchi.

En la novela de Tabucchi, claro, aparecen en primer plano la Lisboa de 1938 y la dictadura de António de Oliveira Salazar, pero la guerra civil de España, el fascismo italiano y otras cosas constituyen algo más que un trasfondo. 5 En concreto, varias referencias al conflicto español parecen

5 De distinta opinión es Nives Trentini quien, en una rica contextualización de Sostiene Pereira, observa que "la Historia, aun documentada en todo su dramatismo con el asesinato de Monteiro Rossi, sigue siendo un trasfondo". Cfr. Una scrittura in partita doppia. Tabucchi fra novela e racconto, Bulzoni, Roma, 2003, p. 234; en la p. 69 se lee: «la historia es solo un trasfondo y el elemento estructurante de la novela es más bien la formación existencial del personaje» (el discurso sobre Sostiene Pereira prosigue en ese sentido, a pesar de que la estudiosa reconozca «la creciente presencia de la historia», hasta la p. 72). Trataremos brevemente de demostrar, obviamente respecto a la guerra civil española, que historia y formación del personaje están estrechamente ligados. En esta nota, en cambio, añadiríamos que, más que a leer la novela, la observación de Trentini, dirigida sustancialmente a evitar una lectura política «forzada» de Sostiene Pereira, puede servir para interpretar la película homónima, realizada por Roberto Faenza en 1995, con la significativa colaboración del autor en los diálogos. En efecto, el largometraje no siempre consigue llenar las «lagunas», los «vacíos» de las "historias cojas» que el novelista, según una sugerente indicación suya, proporciona «al cine» y a "directores susceptibles a los vacíos». En Sostiene Pereira creo que se manifiesta cierta «susceptibilidad a los vacíos» de Roberto Faenza, sobre todo por lo que se refiere al contexto histórico que, como cuadro y sentido de una época pero también como suma de acontecimientos y hechos de una trama, es representado siguiendo los estereotipos de los que abusa gran parte del cine engagé, lo que lo convierte en un trasfondo, precisamente, y a menudo nada más que en eso. La película consigue, significativamente, capturar en los diálogos tabucchianos —absorbidos en la novela por el universo del doctor Pereira, asimilan los continuos y cada vez más consistentes relieves históricos - la fragmentaria toma de conciencia, el aprendizaje del «sostener» del doctor Pereira (encarnado, en una muy feliz elección, por el gran Marcello Mastroianni), y hasta la parábola existencial de otros dos personajes (pese a la interpretación no entusiasmante de Stefano Dionisi, que es Monteiro Rossi, y de Nicoletta Braschi, que no hace revivir a esa criatura de ensueño, esa joven femme fatale, silueta inasible, metamórfica, que en la novela es Marta, «bellísima, de piel clara y ojos verdes [...] pelo castańo con reflejos rojizos»; "pelo rojo [...] bella silueta que se recortaba al sol»; "Marta parecía transformada, esos cabellos rubios y cortos, con el flequillo y las curvas sobre las orejas, le daban un aire pillo y extranjero, acaso francés»). Para las citas entre paréntesis cfr. Antonio Tabucchi, Sostiene Pereira, Feltrinelli, Milán, 1994, pp. 27-28, 96 y 99, 138 (Sostiene Pereira: una declaración, trads. Carlos Gumpert y Javier González, Anagrama, Barcelona, 2003); 


\section{ANTONIO TABUCCHI SOSTIENE PEREIRA}

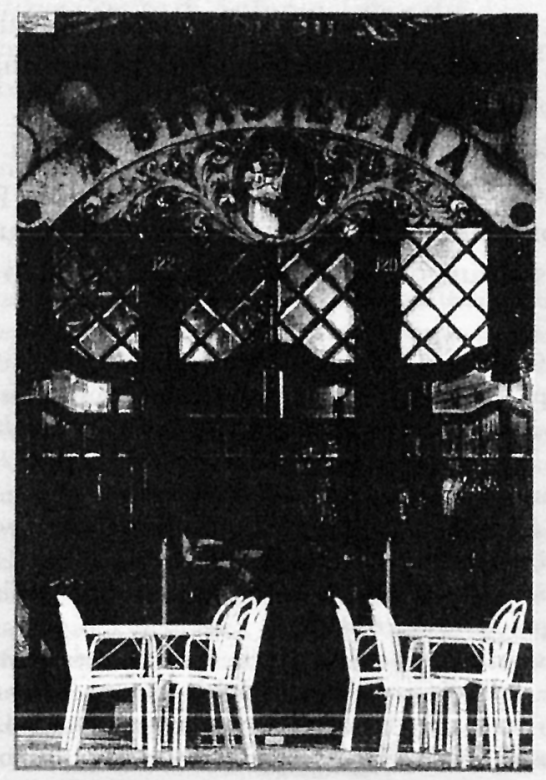


realmente acompañar la fragmentaria y progresiva toma de conciencia del doctor Pereira, que en 1938 puede hallar un modelo en la de Georges Bernanos, cuya "toma de conciencia muy progresiva» se materializa en Los grandes cementerios bajo la luna, mayo de 1938, como la de Pereira se materializa, en el verano de aquel año, en la necrológica por el joven Monteiro Rossi: "Asesinado un periodista». Necrológica, firmada, que es el instrumento de tal toma de conciencia y "un testimonio», como reza el subtítulo de Sostiene Pereira, que en parte se aproximaría a ese "diario de un testigo" que se leía en la primera redacción de Los grandes cementerios bajo la luna. Es más, Pereira escribe en Portugal su artículo y piensa en Portugal («Invitamos a las autoridades competentes a vigilar atentamente [...] hoy en Portugal»), ${ }^{6}$ justo como Bernanos «escribe su libro en Francia, pensando en Francia, en sus problemas nacionales e internacionales, que él pone en forma de reflexiones». ${ }^{7}$

Inicialmente, en Sostiene Pereira no hay más que insinuaciones, fragmentos precisamente, detalles diseminados, como la Lisboa y el Portugal de 1938, en una monolítica y fúnebre deriva de Europa y del mundo en los años treinta, entre fiestas salazaristas, canciones franquistas, ecos de la guerra civil y del fascismo italiano, y fanáticos, vándalos, xenófobos, antisemitas. ${ }^{8}$

Y pensó: esta ciudad apesta a muerte, toda Europa apesta a muerte.

Luego vio una pancarta [...] Honor a Francisco Franco. Debajo, en letras más pequeñas: Honor a los militares portugueses en España [...] era una fiesta salazarista [...] de sus cuerdas melancólicas extraían una canción franquista [...] no quiero ir a Italia, creo que la situación es aún peor que la nuestra [está hablando Monteiro Rossi].

para las anteriores, véase igualmente Tabucchi, «Come nasce una storia», en Anna Dolfi y Maria Carla Papini (eds.), Scrittori a confronto. Incontri con Aldo Busi, Maria Corti, Claudio Magris, Giuliana Morandini, Roberto Pazzi, Edoardo Sanguineti, Francesca Sanvitale, Antonio Tabucchi, Bulzoni, Roma, 1998, p. 196 (cfr. también p. 186). Permítaseme, por último, remitirme a Curreri, "Letteratura e cinema: il caso Tabucchi», conferencia pronunciada en la Universidad de Varsovia, el 16 de noviembre de 2005, que se publicará en la revista Il lettore di provincia.

6 Cfr. Antonio Tabucchi, Sostiene Pereira, cit., pp. 202-203.

7 Max Milner, "La guerre d'Espagne», en Georges Bernanos, Desclée de Brouwer, París, 1967, pp. 231, 232 y 248.

8 Cfr. Tabucchi, Sostiene Pereira, cit., pp. 14, 20-23, 28, 57. 
Oh, exclamó Pereira, mi juventud se fue hace tiempo. En cuanto a la política, aparte de que no me interesa mucho, no me gustan los fanáticos, creo que el mundo está lleno de ellos.

[...] vivimos en un mundo de vándalos, han sido los vándalos [habla David, propietario judío de una carnicería]. ¿Ha llamado a la policía?, preguntó Pereira. Para qué, dijo David, para qué.

Pero después tales referencias se hacen autónomas y poco a poco se imponen, de un modo constante y progresivo, en unos quince fragmentos de la novela. ${ }^{9}$ Extractando, me limito a poner como ejemplo cuatro pasajes consecutivos del texto:

Peligroso, sostiene, el artículo era peligroso. Hablaba de la España profunda, de la muy católica España que García Lorca había puesto en su punto de mira en La casa de Bernarda Alba [...] no sé si usted se da cuenta, querido Monteiro Rossi, de que en este momento en España hay una guerra civil, que las autoridades portuguesas piensan como el general Francisco Franco y que García Lorca era un subversivo; eso es: un subversivo.

Pereira preguntó a Silva qué pensaba sobre [...] lo que estaba pasando en Europa. Oh, no te preocupes, replicó ella, aquí no estamos en Europa, estamos en Portugal [...] Pero ¿`sabes qué sucede en Alemania e Italia? Son fanáticos, quieren someter el mundo a hierro y fuego. No te preocupes, respondió Silva, están lejos. De acuerdo, dijo Pereira, pero Espańa no, está a dos pasos, ¿y sabes lo que pasa en España? Una carnicería, y sin embargo había un gobierno constitucional. Todo por culpa de un general beato. También España está lejos, repuso Silva, nosotros vivimos en Portugal. Así será, dijo Pereira, pero tampoco aquí las cosas van bien, la policía manda, mata a la gente, hay registros, censuras, este es un estado autoritario [...] escucha, te digo una cosa, yo enseńo literatura y de esto entiendo, estoy haciendo una edición crítica sobre nuestros trovadores [...] Pero yo soy periodista, replicó Pereira. ¿Y qué?, dijo Silva. Pues que debo ser libre, dijo Pereira, e informar a la gente de manera correcta. No veo la conexión, dijo Silva, tú no escribes artículos de política, llevas la página de cultura.

¿Entonces?, preguntó Pereira. Pues que ha venido mi primo, respondió Monteiro Rossi. No me parece tan grave, repuso Pereira, todos tenemos primos. Sí, dijo Monteiro Rossi casi en un susurro, pero el mío viene de España, está en una brigada, lucha del lado de los republicanos; está en Portugal para reclutar voluntarios portugueses que quieran formar parte de una brigada internacional. En mi casa no puedo hospedarlo, tiene pasaporte argentino y se ve a un kilómetro que es falso; no sé dónde meterlo, dónde esconderlo. Pereira empezó a sentir un hilo de sudor que le bajaba por la espalda, pero mantuvo la calma. [...] ¿Y qué?, siguió preguntando Pereira.

9 Ib., pp. 37-38, 63-64, 80-81, 85-86, 97-98, 122, 128-129, 139-140, 145-147, $154-156,166-169,177$ y 204 
Pues que de usted nadie sospecha, dijo Monteiro Rossi, él se queda aquí unos días, el tiempo de entrar en contacto con la resistencia, y luego vuelve a España. Tiene que ayudarme, doctor Pereira, tiene que buscarle un refugio.

[...] Pereira entró en la pensión pero aconsejó a Monteiro Rossi que esperara fuera, se hizo acompañar del señor Bruno Rossi y lo presentó al empleado. Era un vejete de gafas gruesas que dormitaba tras el mostrador. Le presento a un amigo argentino, dijo Pereira, el señor Bruno Lugones, este es su pasaporte, pero le gustaría mantener el anonimato, está aquí por razones sentimentales. El vejete se quitó las gafas y hojeó el registro. Esta mañana ha telefoneado una persona para hacer una reserva, dijo, ¿̇es usted? Yo soy, confirmó Pereira. [...] cogió la cartera y sacó dos billetes. Le dejo pagados tres días [...]. ${ }^{10}$

Cuanto más se avanza en la lectura, más consistentes son las referencias a la guerra civil espańola, pasando significativamente de un artículo literario a una discusión política, donde Pereira toma distancia de Silva, reivindica su papel de "periodista» («ser libre [...] e informar a la gente de manera correcta») ${ }^{11}$ incluso desde las páginas culturales y, al calor de una necrológica escrita por Monteiro Rossi, cita a Marinetti, al que volveremos, como triste ejemplo de cruce entre literatura y política; poco después, Pereira pasa de la discusión a un compromiso concreto, ocupándose del primo de Monteiro, Bruno Rossi, que «viene de España» y "está en Portugal para reclutar voluntarios portugueses que quieran formar parte de una brigada internacional». ${ }^{12} \mathrm{Y}$ aunque Pereira declare "yo no soy camarada de nadie», ${ }^{13}$ de hecho actúa como un «camarada».

También cuantitativamente, luego, se pasa de una rápida insinuación, de un detalle narrativo no precisamente insignificante, a páginas e incluso capítulos casi enteramente dedicados (o, por lo menos, que giran en torno) a la guerra, a lo que de ella se sabe, se dice, se escribe. Baste pensar, hacia el final del libro, en el capítulo 19, centrado en la conversación entre Pereira y el padre Antonio, o en el capítulo 20, donde asis-

10 Ib., pp. 37-38, 63-64, 80-81 y 88-89.

11 Ib., pp. 64-65.

12 Ib., p. 80. El primo de Monteiro aparece y desaparece en la trama, pp. 80-81, 8586, 97-98, etc., pero está presente incluso in absentia, y de su actividad dependerá, en cierto modo, la trágica resolución de la historia y la dolorosa toma de conciencia del viejo periodista, el doctor Pereira.

13 Ib., p. 86 
timos a la que mantiene con el doctor Cardoso: capítulos y conversaciones esenciales, y no por casualidad, para la toma de conciencia política de Pereira (no solo literaria, que de todos modos puede ser un válido apoyo de aquella, de la que no está desligada) y para el desenlace de la trama, que ve como un hombre, un intelectual, traductor, periodista, afronta todo el dramatismo, toda la violencia de la historia, reaccionando con eficacia — en la estela de la huidiza relación padres-hijos, viejosjóvenes - al asesinato del joven Monteiro Rossi, el otro, el amigo, el hijo, el colaborador literario, el subversivo, y salvando en fin, en cuanto héroe intelectual, la distancia que media entre arte y vida, literatura y engagement. Porque el doctor Pereira es engagé, en cierto modo, sobre todo si se presta la debida atención a cuanto, remontándose a Sartre, sugiere el propio Tabucchi: "Escritor engagé es el que se ocupa de los hechos ajenos». ${ }^{14}$

El punto de vista de Pereira y su acceso a la responsabilidad ante el mundo de los años treinta se desarrolla también — sobre todo, me atrevería a decir- por lo que alcanza a «sostener» sobre la guerra civil española y el engagement que, partiendo de Marta y el primo de Monteiro, Bruno Rossi, sacude al mismo Monteiro y a Pereira.

Por lo demás, es Tabucchi quien nos invita a fundir el personaje protagonista con la historia cuando dice que "Pereira es infeliz no solo por razones personales, existenciales [...], sino también por la situación histórica en la que vive». ${ }^{15}$ Introducir esa situación histórica, los nazifascismos y el bloque totalitario europeo que, a la altura de 1938, conforman Portugal y España, Italia y Alemania, en el universo de un personaje «viudo, cardiopático, grueso", no significa necesariamente dejarla como telón de fondo, ni tampoco proyectarla completamente en la Italia electoral de 1994, como sugiere Luca Doninelli, quien en un artículo del 9 de marzo

14 Tabucchi, «Come nasce una storia», cit., p. 181. Para Sartre y su contexto en un panorama cultural francés cuyo punto de partida es Pascal, cfr. Benoît Denis, Littérature et engagement. De Pascal à Sartre, col. Points Éssais serie Lettres, Seuil, París, 2000, volumen que merece la pena recorrer porque en él Jean-Paul Sartre es una presencia estructurante; cfr. en particular, de la primera parte, introductoria, clara y eficaz, el cap. III, "El escritor comprometido: una presencia total», pp. 43-51, y de la tercera y última, el cap. XIII, «El apogeo sartriano», pp. 259-279. Cfr. además el epígrafe 2 del primer capítulo.

15 "Come nasce una storia», cit., p. 192. 
de ese año aparecido en $I l$ Giornale ${ }^{16}$ acusa a Tabucchi de haber escrito un libro de propaganda electoral, inspirándose en una visión todavía soviética de la historia.

Llevada al extremo, la observación de Doninelli podría despistarnos, sobreponiendo por completo ese tipo de visión histórica a la interpretación estrictamente literaria de quien, en Sostiene Pereira, ve la historia como trasfondo y, en primer plano, el sueño. En definitiva, habremos de elegir o, en última instancia, situarnos entre un anacrónico y viciado engagement y la constante onírica de la prosa tabucchiana. Cuando tal vez la verdad está en el medio, pues Tabucchi confiesa que no se reconoce completamente en Sostiene Pereira, entendida solo como novela comprometida, sino que más bien cree en una novela existencial «que habla de una crisis de conciencia muy amplia, que se refiere al pasado, al futuro, a la

16 Luca Doninelli, «Macché letteratura, è propaganda», Il Giornale, 9 de marzo de 1994, para lo cual cfr. Tabucchi, Sostiene Pereira, introd. y análisis de Bruno Ferraro, col. Il Passo del Cavallo, Loescher, Turín, 1995, pp. 41-43 y 47. Del artículo de Doninelli vuelve a dar noticia L'Indice, 4, 2004, p. 10, como para «equilibrar» la recensión, "Lui amò Rosamunda», que Luciana Stegagno Picchio hace de la última novela de Tabucchi, Tristano muore. Una vita, Feltrinelli, Milán, 2004 (Tristano muere, trad. Carlos Gumpert, Anagrama, Barcelona, 2004), donde todavía se trata de España, del Generalísimo (pp. 62-65, por ejemplo), de la fuga de Benjamin («de Franco, de Hitler y de todos, tal vez incluso de sí mismo", p. 108) y de otras muchas cosas del siglo XX: "Un siglo que apenas ha echado el telón sobre nuestra dudas y certezas, ideologías y desilusiones. Y que ahora nos pasa el testigo para el nuevo. Pero ¿quién testifica a favor del testigo?». Recensión apasionada de la "maestra» de Antonio Tabucchi, llena de intuiciones, aunque un poco "apocalíptica», jugada sobre el estribillo «de uno de esos viejos e inútiles, de esos Tristanes casi cadáveres que han comprendido que la historia es una ilusión, un fantasma, aun cuando ya no pueden hacerla porque ya ha sido hecha». Citamos estos pasajes de la recensión de Stegagno Picchio sobre Tristano muere como ejemplo de una recepción potencialmente «ahistórica» del novelar tabucchiano - en cierto modo la preferida por el mismo autor, con sus montajes narrativos de tipo fabulístico, desde Piazza d'Italia (1975) - y opuesta a la lectura crítica actualizadora a ultranza, difundida sobre todo a partir de la publicación de Sostiene Pereira. La de Stegagno Picchio es, de todos modos, una interesante recensión, de la que he partido, junto con otras, para escribir un ensayo en torno a Tabucchi y Magris. Cfr. Curreri, «La sfida di non farsi leggere. Appunti intorno a Tristano muore (2004) di Tabucchi e Alla cieca (2005) di Magris», en Angela Barwig y Thomas Stauder (eds.), Intellettuali italiani del secondo Novecento, Verlag für Deutsch-Italienische Studien, Oldenbourg, 2007, pp. 176195. Léase además, también referido a España y la guerra civil, Tabucchi, Piazza d'Italia. Favola popolare in tre tempi, un epilogo e un'appendice (1975), Feltrinelli, Milán, 1993, y en la col. Universale Economica, 1996 y 2003, pp. 70, 91 y 132 (Piazza d'Italia: fábula popular en tres actos, un epílogo y un apéndice, trads. Carlos Gumpert y Xavier González Rovira, Anagrama, Barcelona, 1998). 
elaboración del dolor, a las elecciones vitales» y que culmina en «un sentido del remordimiento»: "Cuando se siente invadido por este gran remordimiento, del que el médico-filósofo Cardoso le hace tomar conciencia, Pereira empieza a poner en tela de juicio incluso su ser político, en un momento como el de Portugal en 1938 y en una Europa al borde de la catástrofe». ${ }^{17}$

Pero tratemos de cuestionar la mencionada alternativa: «propaganda» para Luca Doninelli, «instancia onírica» para Nives Trentini, siguiendo brevemente la aparición en el texto - y las «citas»— de célebres escritores.

Por un lado, es verdad que, aunque solo sea literariamente, parecen maniqueas y fáciles las evocaciones - y su cadencia, como la de las parejas de opuestos que va instituyendo la novela - de escritores italianos y extranjeros, que presentarían, en potenciales necrológicas y aniversarios, al «malvado» Filippo Tommaso Marinetti —capítulo 7-y al «buen» Vladímir Vladimirovich Maiakovski — capítulo 19, significativamente hacia el final del texto- - Por otro lado, no se puede reducir esta pareja u otra, acaso menos evidente (Paul Claudel contra Georges Bernanos), a una visión totalmente propagandística y soviética de la historia.

Pensemos en un caso más interesante y a la vez más complicado, el de Luigi Pirandello y Gabriele D’Annunzio. Del siciliano se cita, al final del primer capítulo, Sogno (ma forse no), «como caracterizando la naturaleza de la novela», que coincide, según Nives Trentini, con «la instancia onírica». ${ }^{18}$

Pero Pirandello parece ser el polo positivo de un par cuyo polo negativo sería D'Annunzio, citado casi a continuación, en el capítulo 4 y luego - con significativa insistencia (también frente a Pirandello) — en otras partes de la novela. De este modo, en mi opinión, se quiere, cuando menos, caracterizar otra no menos importante instancia de Sostiene Pereira: la histórica, histórico-política, ideológica, denunciando en consecuencia, aunque de manera fácil, el papel de vate y «superhombre disminuido»

17 Cfr. Paola Gaglianone y Marco Cassini (eds.), Conversazione con Antonio Tabucchi. Dove va il romanzo?, ensayo crítico de Riccardo Scrivano, nota de Roberto Faenza, col. Il Libro Che Non C’è, Omicron, Roma, 1995, pp. 18-19.

18 Cfr. Trentini, Una scrittura in partita doppia. Tabucchi fra novela e racconto, cit., pp. 224-225. 
de D’Annunzio, amante de la grandilocuencia y la acción, del erotismo y el intervencionismo; todo ello casi resumido en el apodo Solo de Trombón, ${ }^{19}$ un hallazgo de Fernando Pessoa, autor amadísimo por Tabucchi, como se sabe, y puesto al lado de Pirandello por la tradición crítica tabucchiana y por Trentini.

Resulta además significativo que sea Pereira, el primer Pereira, quien piense en Luigi Pirandello, al comienzo de la novela, mientras que el joven Monteiro Rossi pone sobre el tapete y también en juego — siguiendo los pasos de Carlo Salinari y Arcangelo Leone de Castris ${ }^{20}$ más que de Pessoa- a Gabriele D’Annunzio. ¿Por qué? Porque de creer, más adelante, en la formación del doctor Pereira, en su toma de conciencia, Luigi Pirandello al principio no es únicamente un punto de referencia ejemplar - que no solo identifica el sueño-, sino también, sencillamente, un dato literario, una medida de la fe pereiriana en la literatura para la cual necesita un complemento histórico - histórico-literario- realmente «otro», que fuerce al culto periodista a revisar y reavivar esa fe. D'Annunzio, muerto el 1 de marzo de 1938, se convierte fácilmente en símbolo de aquella «Europa [que en julio de 1938] apesta a muerte», como se lee en el capítulo 2; y es sobre todo la Europa de los fascismos italiano y español y de la guerra civil la que emerge en el capítulo 3 y casi parece visualizarse en la muerte de D’Annunzio del capítulo 4 (antes de desembocar en las muertes, todavía lejanas, de Marinetti y Mussolini, citados a continuación). ${ }^{21}$

Claro que presentar así a Pirandello significa envolverlo en el dato literario y conservarlo allí, casi por encima de las partes, como parece suceder en la realidad y en la historia de la recepción pirandelliana, que en la época de Sogno ( $m a$ forse no) era óptima, a derecha e izquierda, en Rusia como en Portugal. Efectivamente, el acto único publicado en La Lettura en octubre de 1929, anunciado como "tragicomedia» por La Gazzetta del Popolo en junio de ese año, aparece, como se lee en el periódico turinés, en un momento en que Pirandello «se apresta a hacer un ingreso decidida-

19 Cfr. Tabucchi, Sostiene Pereira, cit., pp. 29 y 95-96; pero también las pp. 87-88.

20 Cfr., respectivamente, Carlo Salinari, "Il superuomo", en Miti e coscienza del decadentismo italiano, Feltrinelli, Milán, 1960 y 1982, pp. 29-105, y Arcangelo Leone de Castris, "Il "guardaroba dell'eloquenza" ", en Il decadentismo italiano. Svevo Pirandello D'Annunzio, De Donato, Bari, 1974, pp. 209-262.

21 Cfr. Tabucchi, Sostiene Pereira, cit., pp. 14, 19-24, 29. 
mente triunfal en Rusia»—donde "el ministro Lunacharsky [...] ha abolido el decreto de censura que tres o cuatro años antes habían promulgado las autoridades soviéticas contra el teatro pirandelliano»— ${ }^{22}$ y es representado, en el Portugal que bajo Salazar está convirtiéndose en una dictadura, el 22 de septiembre de 1931 en el Teatro Nacional de Lisboa (llegando a su patria, en el teatro Giardino d'Italia de Génova, el 10 de diciembre de 1937, gracias a la Compagnia Filodrammatica de la Universidad).

La estrategia, en definitiva, es hábil pero también engañosa, al menos en ese nivel histórico que se quiere alcanzar sacrificando a D'Annunzio. Pirandello, de hecho, nada extraño al "gusto por la muerte inútil y bella» y al «gusto por la brutalidad» en tiempos de la Primera Guerra Mundial y ascenso al poder de Mussolini, se inscribe en el partido fascista "al día siguiente del asesinato» del diputado socialista Giacomo Matteotti —vuelve sobre ello Marco Maugeri en Le ceneri di Matteotti (2004), reconstrucción a la vez ensayística y narrativa, próxima a textos como los de Fulvio Abbate o, más exactamente, Affinati y Rasy- ${ }^{23} \mathrm{o}$, si se quiere, cerca de cuatro, cinco años antes del Sogno (ma forse no).

Recuerda estos momentos Furio Jesi en Cultura di destra (1979), libro que tal vez nos ha ayudado a entender, más que Salinari, De Castris y tantos otros, la relación entre literatura y vida en esos ańos difíciles y en otros igualmente complicados. ${ }^{24}$

Tiene Sostiene Pereira «un tono político indudable, evidente» - lo dice el mismo Tabucchi- ${ }^{25}$ pero ello no la reduce a novela histórica ni

22 Ivan Pupo (ed.), Interviste a Pirandello, pról. Nino Borsellino, Rubbettino, Soveria Mannelli (Catanzaro), 2002, p. 439.

23 Marco Maugeri, Le ceneri di Matteotti, L’Ancora del Mediterraneo, Nápoles, 2004; en concreto pp. 44-49 y 51-55. Cfr. Fulvio Abbate, Teledurruti, Baldini e Castoldi, Milán, 2002 e Il ministro anarchico, Baldini Castoldi Dalai, Milán, 2004; Eraldo Affinati, Un teologo contro Hitler. Sulle tracce di Dietrich Bonhoeffer, Mondadori, Milán, 2002, y Elisabetta Rasy, La scienza degli addii, Rizzoli, Milán, 2005 (La ciencia del adiós, trad. Pepa Linares, Alianza, Madrid, 2007). Por la parte crítica, Lidia De Federicis, «Il filo della voce», en Del raccontare. Saggi affettivi, Manni, San Cesario di Lecce, 2004, pp. 41-52.

24 Furio Jesi, Cultura di destra, Garzanti, Milán, 1979 y 1993, pp. 148-152 (Cultura de derechas, trad. Rosa Premat, El Aleph, Barcelona, 1989). Cfr. también Luciano Curreri, "Il corpus dell'incompiuto", L'Indice, 7-8, 2005, p. 16.

25 Tabucchi, "Come nasce una storia», en AA.VV., Scrittori a confronto, cit., p. 193. 
hace que sea necesariamente neohistórica, es decir, «más en consonancia, por la "mezcla de diversas tramas", con modelos contemporáneos que funden elementos históricos " $\mathrm{y}$ al mismo tiempo policiacos, sentimentales, de acción y aventura, alegóricos, políticos, filosóficos”»" ${ }^{26}$

El expediente de la novela neohistórica permite más que nada emparentar o aproximar a Tabucchi, con menor reticencia y mayor soltura, tanto a los amados clásicos, Maupassant, Balzac, Tolstoi, citados en Sostiene Pereira junto a Mauriac y Bernanos, ${ }^{27}$ como, en relación con la guerra civil española, a los «jóvenes» Pino Cacucci y Carlo Lucarelli y a Fabrizia Ramondino, generacionalmente más cercana, autora de una novela mallorquina que hace pensar en Georges Bernanos, citado en el texto y en un apéndice, y que se cierra con una nota en homenaje a la novela del siglo XIX donde se recuerda a Dumas y Dostoievski, Balzac y Tolstoi. ${ }^{28}$

Por lo demás, aun antes de la publicación de los trabajos de Lucarelli, Cacucci y Ramondino, Carla Sodini y algunos de sus alumnos —en la conclusión de una obra colectiva, La guerra civile spagnola tra politica e letteratura, editada en 1995 por Shakespeare and Company - reparan precisamente en Sostiene Pereira y titulan, con gesto mimético, "Sostiene Tabucchi ${ }^{29}$ — una entrada ya de la bibliografía tabucchiana— ${ }^{30}$ a causa de una mínima, solicitada y actualizadora participación del autor recogida, un tanto forzadamente, en las últimas líneas y dirigida a enunciar tristes y desde luego advertibles (y advertidas) analogías entre los años treinta y el presente, con el regreso de los nacionalismos, la xenofobia y el racismo.

Intervención que funde así una precisa invocación histórico-política con una sospechosa o por lo menos dudosa y forzada puesta al día, a des-

26 Cfr. Trentini, Una scrittura in partita doppia. Tabucchi fra novela e racconto, cit., p. 235, que usa «la redefinición del género propuesta por Margherita Ganeri (siguiendo a su vez los escritos de Ceserani)», a quien me remito: «Il ritorno postmoderno del romanzo storico: implicazioni teoriche e culturali», Allegoria, 26, 1997, pp. 112-120.

27 Tabucchi, "Come nasce una storia», en AA.VV., Scrittori a confronto, cit., p. 195.

28 Fabrizia Ramondino, Guerra d'infanzia e di Spagna, Einaudi, Turín, 2001, pp. 85, 416 y 425 .

29 Carla Sodini, "A proposito della guerra civile spagnola: sostiene Tabucchi», en Gigliola Sacerdoti Mariani, Arturo Colombo, Antonio Pasinato (eds.), La guerra civile spagnola tra politica e letteratura, Shakespeare and Company, Florencia, 1995, pp. 305-313.

30 Tabucchi, «Sostiene Tabucchi», entrevista de Alberto Scarponi, Lettera Internazionale, 62, 1999, pp. 2-5. 
pecho de la consistencia del texto literario, de la novela histórica de Tabucchi, actualizada y a la vez deslizada al pasado cuando se le pide, en cierto modo, que haga las veces de una tradición novelesca italiana inexistente y/o perdida. Al final, las pocas páginas dedicadas a Sostiene Pereira desafinan casi en un denso volumen donde no hay prácticamente rastro de la narrativa italiana vinculada, más o menos significativamente, al conflicto español; ${ }^{31}$ mientras que destacan, como es habitual, la literatura francesa y la angloamericana, la española e incluso la alemana, con El gran ejemplo de Gustav Regler, escrito en alemán en 1937-1938 pero aparecido en inglés en septiembre de 1940, pocas semanas antes de la novela de Hemingway, que en seguida la eclipsa. ${ }^{32}$

Pero para demostrar que la guerra civil española es para Tabucchi - como antes tal vez solo para Sciascia - un momento fuerte del siglo XX, que no hay que olvidar y al que hay que volver en los difíciles ańos noventa, tensos sobre todo entre revisionismos y nuevos saludos romanos, en los periódicos como en los campos de fútbol, basta leer el inicio y el final de un breve artículo aparecido en el Corriere della Sera el 30 de junio de 1998, "Franchismo, lettera agli amici spagnoli», recogido luego en Due fronti. La grande polemica sulla guerra di Spagna (1998)..$^{33}$

31 Cfr. el segundo capítulo de este libro.

32 Antonio Pasinato, «Tragedia e speranza nella guerra civile spagnola. Il romanzo di Gustav Regler Das große Beispiel (1937-1938)", en AA.VV., La guerra civile spagnola tra politica e letteratura, cit., pp. 231-249. Digo «incluso la alemana» porque sigo pensando, con Maurizio Serra, que cuando italianos y alemanes se enfrentan, en su patria y en Espańa, con el fascismo y el nazismo, no ofrecen fácil ni inmediatamente un tributo a las bellas letras que consiga traducir la realidad de la guerra civil española y, en consecuencia, producen menos obras o de un tipo diverso. Cfr. Maurizio Serra, L'esteta armato. Il Poeta-Condottiero nell'Europa degli anni Trenta, Il Mulino, Bolonia, 1990, p. 130; en la p. 131 recuerda, entre los alemanes, a Hermann Kesten y su Die Kinder von Guernica (1939), con prólogo no precisamente complaciente de Thomas Mann, que juzga inverosímil y excesivo hacer hablar durante 167 páginas a un muchacho de apenas quince años, testigo de la bárbara destrucción de ciudades y de los últimos días de libertad y justicia. Distinto, obviamente, es el asunto relativo a la propaganda fascista y nazi. Para la fascista, a vueltas con narración, teatro y cine, remito otra vez al segundo capítulo de este libro.

33 Tabucchi, «Franchismo, lettera agli amici spagnoli», en Nino Isaia, Edgardo Sogno (eds.), Due fronti. La grande polemica sulla guerra di Spagna, con intervenciones de Mario Pirani, Renzo Foa, Barbara Spinelli, Enrico Deaglio, Sandro Viola, Indro Montanelli, Antonio Tabucchi, Piero Ostellino, Ferdinando Adornato y la réplica de Sergio Romano, Liberal Libri, Florencia, 1998, pp. 166-170. 
En este artículo, Tabucchi vuelve en seguida al vínculo pereirano entre Portugal y España, evoca una memorable exposición de fotografías sobre la España de Franco — citando algunos fragmentos: «la exaltación de brazos extendidos en las ventanillas del tren, en la estación de Madrid de 1941, de la heroica División Azul que por cuenta de Franco iba a devolver a Hitler los favores recibidos por los bombardeos de las ciudades vascas fieles a la república»— ${ }^{34} \mathrm{y}$ concluye con esa censura que tanta importancia tiene en Sostiene Pereira (1994).

Creíamos que mesurados historiadores anglosajones como Gabriel Jackson o Paul Preston nos habrían informado en detalle y suficientemente sobre la guerra civil espańola y la naturaleza del franquismo. Y, sin embargo, un descubrimiento revolucionario está recorriendo estas últimas semanas la historiografía italiana que se hace en los periódicos. Franco fue un estadista de largas miras, el franquismo no era en absoluto un régimen fascista y tuvo, sobre todo, un gran mérito: detuvo la difusión del comunismo en Occidente. Esta tesis novísima, que quien conoce la península ibérica leía en historiadores adeptos en España y Portugal en los años cincuenta y sesenta (las tesis salazaristas eran idénticas a las franquistas), viene seriamente afirmada hoy en Italia por Sergio Romano, embajador retirado de la República italiana, que ha pasado a ocuparse de historia en algunos medios informativos. [...]. Esta es una invitación al Instituto Cervantes y a Publio López Mondéjar para que presenten también en Italia sus fotografías. Si no, a este paso los italianos oirán pronto decir que el saludo romano era un gesto sublime de tańedores de arpa, el garrote un idílico juego de salón, los fusilamientos un baile de época y la censura un consejo paternal. Se escuchará una música celestial y sentiremos mucha nostalgia por la perdida Arcadia franquista. ${ }^{35}$

Me parece estar oyendo a Leonardo Sciascia cuando replicaba entre los ańos cincuenta y sesenta a ese "gran mérito» del franquismo, sostenido por los Estados Unidos de América, a nivel político, y no solo por historiadores espańoles y portugueses adeptos al régimen. Y Portugal, no ya

34 Ib., p. 168. Cfr. además Moreno Juliá, La Division Azul. Sangre española en Rusia, 1941-1945, cit.

35 Tabucchi, "Franchismo, lettera agli amici spagnoli», en Isaia/Sogno (eds.), Due fronti. La grande polemica sulla guerra di Spagna, cit., pp. 166 y 170; tiene otro tono la contribución de Indro Montanelli, pp.163-165, que había hablado de la guerra civil española en el contexto de un lejano ejercicio narrativo recientemente repropuesto y en páginas interesantes y lo bastante objetivas, distintas de sus conclusiones periodísticas de noviembre de 1936 (a este propósito, cfr. Rodondi, Il presente vince sempre, cit., p. 207): Indro Montanelli, Qui non riposano, Tarantola, Milán, 1945, pp. 55-56, 62 y 114-120, y Rizzoli, BUR, Milán, 2001 y 2005, pp. 55, 61 y 113-120. 
solo por obvias razones profesionales, es la piedra de toque y el punto de referencia de Antonio Tabucchi, ${ }^{36}$ asiduo frecuentador de ese país como Sciascia lo era de España.

Pero dejemos a Tabucchi y tratemos de aproximarnos de nuevo a Pino Cacucci, al menos para subrayar que Tina es una biografía novelada de Tina Modotti, personaje histórico cuya vida tiende "naturalmente» a la novela, como la de Koestler, por ejemplo, que atraviesa, aunque de modo diferente, casi los mismos lugares de la historia en la segunda mitad de los años treinta. Tiene buen olfato Cacucci cuando, para recorrer los inicios del siglo XX, sus "certezas absolutas», sus ideologías, sus nacionalismos y también la guerra civil española, apunta sobre Modotti, una mujer - maravillosa, desde luego, y revolucionaria en todos los sentidos: como actriz del cine mudo, modelo, fotógrafa- ${ }^{37}$ en vez de sobre un hombre, digamos Koestler, por más que este sea igualmente ecléctico, misterioso, huidizo, «doble» y, a fin de cuentas, lejano de las sólitas trayectorias heroicas y viriles "en sentido único", hijas de una coherencia que la historia del siglo breve $e^{38}$ ha confiado a programas y mitos antes que a la compleja, frágil realidad.

En definitiva, los perdedores, los perseguidos, los encarcelados empiezan a ser también las perdedoras, las perseguidas, las encarceladas a partir,

36 Recordemos al menos, a caballo entre la juventud y la madurez, Antonio Tabucchi (ed.), La parola interdetta. Poeti surrealisti portoghesi, Einaudi, Turín, 1971, con una amplia introducción, pp. 7-81, cuya primera parte se cierra sobre España y la «relevante ósmosis cultural [...] entre los dos países» (pp. 45-46), y Tabucchi, La Nostalgie, l'automobile et l'infini. Lecture de Pessoa, col. La Librairie du XX Siècle, Seuil, París, 1998, que recoge las lecciones del autor en la parisina École des Hautes Études en Sciences Sociales, noviembre de 1994 (cfr. el prólogo, pp. 7-14).

37 Cfr. también Irme Schaber, Gerda Taro. Une photographe révolutionnaire dans la guerre d'Espagne (1994), Anatolia/Le Rocher, Múnich, 2006, y François Maspero, L'ombre d'une photographe, Gerda Taro, Seuil, París, 2006, pp. 16-27, 53-76, 79-83, 89-98 y 100101. Cacucci la evoca en la citada Tina, p. 164.

38 Cfr. Eric J. Hobsbawm, Age of Extremes. The Short Twentieth Century 1914-1991 (1994), Abacus, Londres, 1995 y 2003, pp. 156-169 (Historia del siglo XX, 1914-1991, trads. Jordi Auraud, Juan José Faci y Carme Castells, Crítica, Barcelona, 2004). También, del mismo autor, Nazioni e nazionalismi dal 1780. Programma, mito, realtà (1990), Einaudi, Turín, 1991 y 2002, pp. 164-166 (Naciones y nacionalismo desde 1780, trad. Jordi Beltrán, Crítica, Barcelona, 1995). 
claro, de una figura femenina no tan ignorada y anónima, entregada además a una rápida parábola existencial, que se cierra antes de los cincuenta años: Tina, justamente, que muere con 46.

Parábola que no puede dejar de traer a la mente, en la otra mitad del siglo y con tonos menos legendarios, la de Dulce Chacón, que pocos meses antes de morir, en 2003, con 49 años, va a Bagdad y se manifesta contra la guerra de Irak y el apoyo español a los EE. UU., y que con $L a$ voz dormida $(2002)^{39}$ había dado voz a los que y, sobre todo, a las que han purgado durante los años de la dictadura franquista, que todavía pesa, por ejemplo, en los nombres de las calles que no han sido cambiados, como «División Azul» en Madrid. Claro que con Dulce Chacón nos movemos hacia sufrimientos anónimos, no difuminados por los excepcionales encuentros que caracterizan, en cambio, la vida de Modotti, que en este sentido termina por parecerse a la epopeya de Nahui Olin en Nahui (2005), del mismo Pino Cacucci. ${ }^{40}$

39 Cfr. Dulce Chacón, Le ragazze di Ventas (2002), trad. Silvia Sichel, Neri Pozza, Vicenza, 2005 (versión italiana de La voz dormida, Alfaguara, Madrid, 2003). Cfr. la hermosa recensión de Danilo Manera, "Donne dagli occhi asciutti», L'Indice, 12, 2005, p. 14, que justamente habla de esta monografía en términos elevados, como de «un libro sonoro y conmovedor». Véase también Patrick Pépin, Histoires intimes de la guerre d'Espagne, 1936-2006. La mémoire des vaincus, France Culture/Nouveau Monde, París, 2006.

40 Pino Cacucci, Nahui, Feltrinelli, Milán, 2005. Cfr. la reseña, en el suplemento semanal de La Stampa, de Sergio Pent, «L'epopea di Carmen, la femmina più desiderata in Messico», TuttoLibri, n. ${ }^{\circ}$ 1486, 2005, p. 3: «Entre sexo y violencia, arte y salones intelectuales, la fémina más deseada de Ciudad de México crece como mujer y como artista, condenada a convertirse en una leyenda viva sin encontrar nunca la verdadera felicidad. Nahui atraviesa una época de fuego, en el recuerdo modelado por los educados y atentos juicios de Cacucci, que al mismo tiempo reconstruye los hechos fugaces y las revoluciones que se sucedían en un país donde pulularon nombres como los de Pancho Villa y Emiliano Zapata, pero también los de Tina Modotti y Diego Rivera, uno de los numerosos amantes ocasionales de Nahui». No compartimos el lisonjero juicio de Pent, pero es cierto que Cacucci, incluso cuando se adentra en caminos trillados (por ejemplo recuperando en Tina, cit., pp. 182-185, la figura de Trotski y su asesino, Ramón Mercader), consigue, con pocas y centradas palabras, reconstruir el cuadro de la situación. Dicho esto, tampoco lleva a cabo una operación como la de Jorge Semprún, La Deuxième Mort de Ramón Mercader, Gallimard, París, 1969, y col. Folio, 1984 y 1999 (La segunda muerte de Ramón Mercader, trad. Carlos Pujol, Planeta, Barcelona, 1978), o la de Julián Gorkin, L’Assassinat de Trotsky, Julliard, París, 1970 (El asesinato de Trotsky, trad. Ramón Margalef, Círculo de Lectores, Barcelona, 1972). Cfr., en fin, Luis Mercader y Germán Sánchez, Mio fratello l'assassino di Trotskij (1990), UTET, Turín, 2006 (Ramón Mercader, mi hermano: cincuenta años después, Espasa-Calpe, Madrid, 1990). 
Aunque en el fondo parece que sea la historia, con sus guerras y, por lo tanto, también con la Guerra de España, la que realmente hace de cada mujer, con o «sin armas», ${ }^{41}$ así como de cada hombre, un elemento excepcional, a un lado y otro de la barricada, viniendo la investigación histórica a moderar una retórica plausible que está en los acontecimientos y en los hechos. Pensemos, más allá de «diferencias de nacionalidad e ideología», en las Palomas de guerra (2002) de Paul Preston: ${ }^{42}$ Priscilla Scott-Ellis, Nan Green, Mercedes Sanz-Bachiller, Margarita Nelken. Y pensemos en las mujeres españolas —en todas ellas y en las mujeres todas - en el exilio. ${ }^{43}$

Tina, por lo demás, podría representar, para nuestros propósitos, un «alba finisecular», pues se publica en 1988 y 1991, respectivamente por Agalev e Interno Giallo, luego por Tea, en 1995 (con sucesivas reimpresiones hasta mayo de 2001, si no me equivoco), y por Feltrinelli, en 2005: los capítulos sobre la guerra civil española son sustancialmente cuatro, del 23 al 26, con una conclusión, si se quiere, en el capítulo 27, y dan la impresión de cuatro cuentos extrapolables, piezas de un rompecabezas en sí mismo que, sin embargo, participa en la operación biográfica, a medias entre la continuidad y el misterio. ${ }^{44}$

Por el contrario, el libro de 2001, Ribelli!, no opta por el monolito, el personaje único y de excepción, sino que se fija en trece trayectorias existenciales no siempre conocidas, que Feltrinelli ha propuesto en su Serie Bianca, colección que difumina el aspecto narrativo buscado por Pino Cacucci y busca salvaguardar, cuando menos editorialmente, esa sensibilidad y esa memoria un tanto "ornamentales» que permiten rescatar y aplaudir — con relativa facilidad - a los rebeldes, o sea, a los espléndidos y solitarios perdedores que han «vencido» en el seno de los diferentes y trá-

41 Véase por entero el ejemplar trabajo de Anna Bravo y Anna Maria Bruzzone, In guerra senza armi. Storie di donne. 1940-1945, Laterza, Roma-Bari, 1995; cfr., en concreto, el primer capítulo: «Mujeres, guerra, memoria», pp. 3-30.

42 Paul Preston, Colombe di guerra: storie di donne nella guerra civile spagnola (2002), Mondadori, Milán, 2006, p. 307 (Palomas de guerra: cinco mujeres marcadas por el enfrentamiento bélico, trad. Jorge Pérez Nistal, Plaza y Janés, Barcelona, 2001).

43 Cfr. Sophie Vallès, «Les femmes républicaines espagnoles, de la seconde République à l'exil: la question de leur identité sociale à travers l'espoir, la guerre civile et l'exode», en Michel Papy (ed.), Les espagnols et la guerre civile, Atlantica, Biarritz, 1999, pp. 351-360.

44 Cacucci, Tina, Interno Giallo, Milán, 1991 y Tea, Milán, 1995 y 2001, pp. 140 169 y 170-174; cfr. además, del mismo autor, Ribelli!, cit., pp. 43-57 y 59-63. 
gicos contextos históricos que les han cobijado. Entre tales contextos reaparece una vez más la Guerra de España con las peripecias de Eulalio Ferrer — que desde México espera excusas por los jóvenes antifascistas escapados a la masacre y dejados pudrir en campos de internamiento franceses- y de Quico, Francisco Sabaté, anarquista irreductible e irónico, inventor de un extraño mortero que disparaba panfletos contra el régimen en medio de manifestaciones franquistas en Barcelona y cuya guerra continuará hasta el 5 de enero de 1960; ese día, durante una de sus operaciones antifranquistas, es asesinado en un pueblecito español, que recuerda a tantas otras pequeñas y míseras aldeas de la Espańa en guerra y es casi una especie de Boadilla del Monte veinte años después. ${ }^{45}$

Situar a Cacucci entre «monumentos» literarios del pasado, entre los testimonios de Koestler o de Romilly, no significa descuidar el aspecto menos convincente de su producción: la búsqueda del mito barato, con buenos y malos puestos en evidencia sobre la página-pizarra para lograr el aplauso adolescente que nosotros, por supuesto, no podemos regalarle.

Nos hemos demorado, relativamente, con Pino Cacucci sobre todo por razones cronológicas, pasando de Tabucchi a Cacucci solo para tratar de dibujar un horizonte que, a mitad de camino entre novela e historia, apunta siempre al personaje. Es decir, la guerra pasa por una toma de conciencia de hombres y mujeres, de personajes más o menos inventados y excepcionales, entregados incluso a cierta recuperación histórica, en seguida auspiciada como el fin último de una formación, de una metamorfosis. La espectacularización del evento bélico, la invocación altisonante y fuertemente simbólica de ciudades heridas cede el primer plano a mujeres y hombres, a su estar y hacer en la historia, a su sacrificio más o menos inmediato. Como hace Leonardo Sciascia en El antimonio, donde, sin embargo, se identifican y alternan ambas realidades: la ciudad y el hombre. Recordemos solo, de pasada: «La ciudad estaba intacta [...] pero fusilaban sin parar». Frase que parece la traducción novelesca de un apunte

45 Remito a Esmond Romilly, Boadilla, Macdonald, Londres, 1937. Cfr. Boadilla. La mia guerra di Spagna, introd. Hugh Thomas, Einaudi, Turín, 1974. "Boadilla del Monte es una pequeña y mísera aldea castellana, a unos veinticinco kilómetros de Madrid», advierte enseguida Thomas en sus primeras líneas (pp. VII-XIII); Hugh Thomas es el autor de The Spanish Civil War (1961 y 1977), que sigue siendo un libro importante (publicado por Einaudi, Turín, 1963, y por Laffont, París, 1961 y 1985). 
redactado por un funcionario de palacio Chigi — tal vez Anfuso, para Renzo De Felice_-, que refiere: «Añádase que Falange es la que más ha "limpiado" las ciudades ocupadas, fusilando todo lo fusilable». ${ }^{46}$

En suma, los textos de Cacucci, tomados en su conjunto, pueden ayudarnos a delimitar y dinamizar la década que va de 1991 a 2001. Apenas transcurrida y nada fácil de asir, de entender, todavía en movimiento, en Italia y en el extranjero, con traducciones, sobre papel o en la pantalla, que hacen de intermediarias y amplían los tiempos. Cacucci es traductor, entre otras cosas, de la afortunada novela de Javier Cercas Soldados de Salamina, de 2001, que en 2003 se convirtió también en film. ${ }^{47}$ La traducción de Cacucci, editada en 2002, ${ }^{48}$ participa del regreso de la guerra civil española a Italia y amplía el cuadro, como lo hace, hoy, la primera parte del nuevo libro de Cercas, La velocidad de la luz (2005), también según la traducción de Cacucci, la reedición de Tina (2005) y Nero di Spagna (2006) de Roberto Baravalle — generacionalmente, entre Tabucchi y Cacucci-, que no ofrece una representación directa de la Guerra de España, sino de sus efectos a través del franquismo (con tristes hechos acaecidos en los años sesenta) y desde la particular óptica de los vascos. ${ }^{49}$

Pero también el cine actual, de manera más o menos autónoma, siente y expresa ese regreso, incluso (lo que es tal vez más revelador) en películas no dedicadas expresamente a ese conflicto; pienso, por ejemplo, en

46 Leonardo Sciascia, Lantimonio, cit., p. 181. Cfr. Renzo De Felice, Mussolini il duce. Lo stato totalitario. 1936-1940, Einaudi, Turín, 1981 y luego en la col. Tascabili, 1996, pp. 378-379. N. de los T.: el palacio Chigi es la sede del gobierno italiano; Filippo Anfuso, un embajador de Mussolini que había participado en la guerra civil española como teniente de artillería.

47 Para la película, cfr. Javier Cercas y David Trueba, Diálogos de Salamina. Un paseo por el cine y la literatura, Tusquets, Barcelona, 2003, y lo que de ella decía, en tono profético y relativamente dispuesto, por una vez, a cierto "compromiso", Goffredo Fofi, "Le maschere dell'eroe», Film-TV, 8, 2002, p. 114: «Soldados de Salamina está dispuesta para ser una película aguda como la novela. Pero, para empezar, ¡disfrutad de la novela! Será también astuta, pero se lee de un tirón».

48 Javier Cercas, Soldados de Salamina, Tusquets, Barcelona, 2001, traducida por Pino Cacci como Soldati di Salamina, Guanda, Parma, 2002.

49 Cfr. Cercas, La velocità della luce (2005), trad. Pino Cacucci, Guanda, Parma, 2006 (La velocidad de la luz apareció originalmente en Tusquets, Barcelona, 2005) y Cacucci, Tina, col. Universale Economica Feltrinelli, Milán, 2005; Roberto Baravalle, Nero di Spagna, pról. Giancarlo De Cataldo, Nerosubianco, Cuneo, 2006, pp. 13-14, 23 $26,61,87$ y 91 . 
la reciente Triple agente (2003) de Eric Rohmer, con quien de nuevo estamos en la generación de Sciascia, en los encuentros históricos, culturales, literarios que la conforman, aun dentro de lo específico de cada autor.

Respecto a tales encuentros, Cacucci personifica - justo es repetirlo- una suerte de límite cronológico, doble y móvil, más que un límite literario puro, caso de Sciascia. Nos ayuda a circunscribir y ampliar, entre 1988 y 2005-2006, el decenio 1991-2001, en que confluyen diversísimos textos narrativos.

Verdaderamente, parece que el espectro de la guerra civil española pueda ocupar todas las casillas, hasta las más insólitas y lejanas de su horizonte, reaflorando rápida e inesperadamente. Un ejemplo, en ese sentido, lo proporciona la primera novela de Valerio Evangelisti, Nicolás Eymerich, inquisidor, de 1994.

Cynthia le miró con ojos desorbitados, como si tuviese delante a un idiota.

- ¿Estás de broma? ¿No te das cuenta de lo que está pasando? ¿No te has enterado de que han despedido a todos nuestros colegas homosexuales? niños...

-Bueno, desde cierto punto de vista, dejarles en contacto con los

Las mejillas de la muchacha se pusieron encarnadas de indignación.

- ¡Marcus, no te reconozco! — gritó.

De repente se le humedecieron los ojos. Para Frullifer fue un golpe bajo. Pero Cynthia siguió, tratando claramente de dominar la emoción:

-Aquí en Astrofísica no han cambiado mucho las cosas, pero en el departamento de Historia sí. [...] En Historia contemporánea han echado a dos tercios de los profesores. A uno, por haber afirmado que durante la guerra de España tenían razón los republicanos y no Franco; a otro, por haber dicho que los campos de concentración nazis eran horrorosos mataderos. ¿Te das cuenta? ${ }^{30}$

Reseñemos ahora algunos botones de muestra, antes de ofrecer de ellos una lectura centrada en Madrid, ${ }^{51}$ Guernica $^{52}$ y otras ciudades heri-

50 Valerio Evangelisti, Nicolas Eymerich, inquisitore, col. Urania, Mondadori, Milán, 1994 y col. Piccola Biblioteca Oscar Mondadori, 2004, p. 206 (Nicolás Eymerich, inquisidor, trad. Francisco Amella, Mondadori, Barcelona, 1999).

51 Para Madrid, véase al menos Carlos Serrano (ed.), Madrid, 1936-1939. Un peuple en résistance ou l'épopée ambiguë, col. Mémoires, Autrement, París, 1991; en particular los artículos del mismo Serrano, "Madrid 1936-1939: un des repères de la conscience européenne», pp. 12-18, y de Émile Temime, "Le mythe et la réalité», pp. 20-30, en la primera parte, que hace de prólogo. De José Carlos Mainer, «Madridgrad ou le regard des autres», 
das. Comencemos por Guernica, novela breve o cuento largo de Lucarelli, publicado por Il Minotauro en 1996 y reeditado por Einaudi en 2000, en seguida anunciada como obra maestra y en realidad muy débil y sin auténtico aliento histórico; aliento que también falta, aunque con resultados bien distintos, en L'isola dell'angelo caduto, de 1999, donde la rareza de la historia y de sus personajes sostiene la idea de un mundo aparte y su finalidad novelesca. En Guernica, en cambio, pasa justamente lo contrario. Como quiera que no hay una idea fuerte para releer la España de la segunda mitad de los años treinta, se recurre a la historia, pero usándola solo como trasfondo, más o menos espectacular, a base de ciudades heridas y conocidos personajes de la época, pegados al texto como si fueran cromos: la Modotti, como ya hiciera Pino Cacucci, el acostumbrado Hemingway, y además Robert Capa, y hasta García Lorca.

El mismo Federico García Lorca que vuelve, con otra fuerza y casi con "atmósferas y personajes hemingwayanos», ${ }^{53}$ en The Horseman's Song de Ben Pastor, ${ }^{54}$ novela de 2003 con interesantes imágenes para nuestros propósitos — «el pequeño avión reapareció en lo alto del cielo de la Sierra,

pp. 102-122, en la segunda («Un souffle épique»), y de Julio Arostegui, «Lagonie», pp. 256-265, en la cuarta parte («Du mythe à l'histoire»); léase toda la tercera parte: «La projection symbolique».

(Viene de la página anterior) 52 Para Guernica, cfr. Herbert R. Southworth, La Destruction de Guernica. Journalisme diplomatie propagande et histoire, pról. Pierre Vilar, Ruedo Ibérico, París, 1975, todavía hoy las versiones más atendibles (Destrucción de Guernica, Cosmos, Valencia, 1977); cfr. a este propósito el juicio experto de Gabriele Ranzato, L'eclissi della democrazia. La guerra civile spagnola e le sue origini 1931-1939, cit., p. 492, n. 181. Sobre el alcance simbólico de Guernica en el presente, cfr. André Glucksmann, Dostö̈evski à Manhattan, Laffont, París, 2002, pp. 18-24 (Dostoievski en Manhattan, trad. María Cordón, Taurus, Madrid, 2002), que habla de un cortocircuito entre Nueva York y Guernica en virtud del cual invita a repensar - aún en el amanecer del nuevo milenio y en un contexto "post» 11 de septiembre - la guerra y sus destrucciones, desde una perspectiva anclada en un discurso ininterrumpido de la modernidad, que el mismo Glucksmann había tratado de rastrear en su primer, lejano y feliz trabajo: Le Discours de la guerre, Éditions de L'Herne, París, 1967 y col. 10-18 de Union Générale d'Éditions, París, 1974, con pról. de Jeannette Colombel, pp. 9-19, que relee la obra de Glucksmann en un contexto "post» Mayo del 68 (El discurso de la guerra, Anagrama, Barcelona, 1969). Cfr., en fin, AA.VV., «Metropolis. Storie di città ferite», Diario, suplemento al n. ${ }^{\circ} 46,2001$, pp. 20-31 y 110-111. Y Angelo d'Orsi, Guernica, 1937. Le bombe, la barbarie, la menzogna, Donzelli, Roma, 2007.

53 Sergio Pent, «Suona la campana per García Lorca», ttL TuttoLibri, 1427, 2004, p. 7; cfr. también la reseńa de Daniele Rocca en la revista L'Indice, 1, 2005, p. 30.

54 Ben Pastor, La canzone del cavaliere (2003), trad. Paola Bonini, col. Giallo e Nero, Hobby e Work, Milán, 2004; la cita corresponde a la p. 157. 

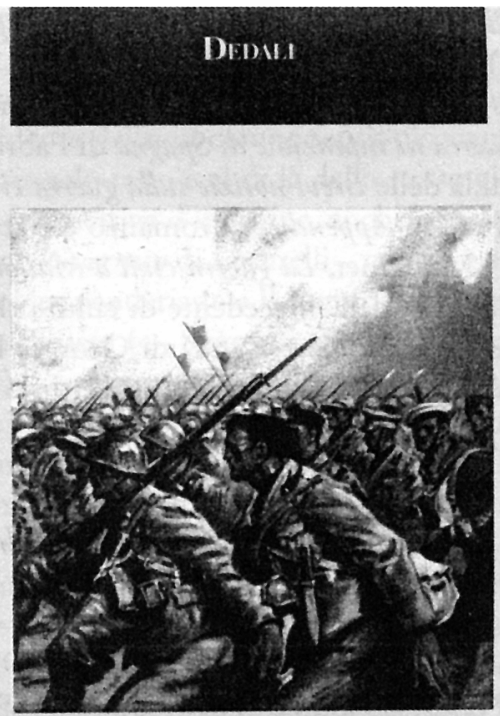

Carlo Lucarelli

Guernica

Romanzo

\section{IL MINOTAURO}


puntual [...] se trataba de un aparato ligero, que volaba en redondo como una falena alrededor de la llama»_ y animada por una hipótesis detectivesca nada banal que pospone la muerte del poeta a 1937, como amplificando el silencio y la mixtificación de la prensa de la época sobre la muerte de Lorca en el verano de $1936^{55}$ y enlazando casi con «el misterioso doble fin de Eusebio" ${ }^{56}$ poeta que, tratando de sustraerse al fusilamiento, se refugia en un centro psiquiátrico en Las semanas del jardin. Un círculo de lectores (1997), de Juan Goytisolo. ${ }^{57}$ Sobre otros textos de narradores extranjeros, más o menos conocidos y acogidos en Italia recientemente, en relación con el revival de la Guerra de España, volveremos en el epígrafe 2 , con parcas citas y tratando en todo caso de presentarles rápidamente mediante traducciones, recensiones y entrevistas.

Hay que precisar en seguida el intento de Ben Pastor — significativo, aunque no siempre logrado- de no reducir la historia de Espańa y la muerte de Lorca a un trasfondo, creando más bien un lugar de ficción en el que salvaguardar una y otra, como si fuera dentro del dolor de una metanarración sucia, a menudo confiada a los diálogos de los personajes, que discuten, hablan, charlan sobre la historia: "Apenas ha amanecido, hostia, demasiado temprano para discutir. Escucha, yo solo digo que Lorca tenía miedo del $N K V D$. ¿Le quieres dar una importancia histórica a todo este asunto? Bueno, la sección de Asuntos Exteriores del Narodnyi Komissariat Vnutrennic Del está implicada, ya lo creo. [...] ¿Y qué diablos es la historia? ¿Acaso esta no es historia? ¡Tú mismo has dicho que dentro de cien años a nadie le importará nada! Yo solo he comunicado a Soler que Federico ha muerto, y le he prohibido difundir la noticia a quienquiera que sea». ${ }^{58}$

55 Cfr. el excelente trabajo de Laura Dolfi, «Agosto 1936: silenzio e mistificazione (La stampa sulla morte di García Lorca)", en Laura Dolfi (ed.), Federico García Lorca e il suo tempo, Bulzoni, Roma, 1999, pp. 305-412. Cfr., de la misma autora, Il caso García Lorca. Dalla Spagna all'Italia, Bulzoni, Roma, 2006, pp. 9-172.

56 Cfr. Bruno Arpaia, «La misteriosa doppia fine di Eusebio», suplemento Domenica de Il Sole-24 Ore, 336, 2004, p. 32; Natalia Cancellieri, "Un uomo di carta», L'Indice, 4, 2005, p. 10.

57 Cfr. Juan Goytisolo, Le settimane del giardino (1997), trad. y notas de Glauco Felici, Einaudi, Turín, 2004 (Las semanas del jardín apareció primero en Alfaguara, Madrid, 1997).

58 Pastor, La canzone del cavaliere, cit., pp. 159-160; cfr. además los diálogos, desde el otro lado de la barricada, de Bora y Serrano, pp. 167-169. 
Es más, mientras The Horseman's Song flirtea realmente con Hemingway y su «Me gusta charlar. Es la única cosa civilizada que nos ha quedado», además de con una hipótesis detectivesca, ligada entre otras cosas a un personaje, Martin Bora, que está en la base de un ciclo histórico (de tan «negro», apocalíptico), Guernica de Carlo Lucarelli no tiene en cuenta siquiera las más recientes aportaciones — tal vez no vinculadas directamente a la Guerra de España, pero sí a la propia tradición y escuela— del género policiaco más visionario. Me refiero, sobre todo, a un cuento largo o novela breve de Pierre Magnan, titulado también Guernica, de 1991, que es una historia simbólica y terrorífica de enterradas vivas, recogida luego en Les Secrets de Laviolette, de 1992, pero publicada independientemente en Italia por Biblioteca del Vascello en 1994 y reeditada por Edizioni Robin en 2001.59

Demos un paso atrás y volvamos al año 2000, al 9 de julio exactamente: aparece en el periódico L'Unione Sarda un cuento inédito de Massimo Carlotto, "Amore e odio di un gitano a Guernica»; y el 23 de agosto de ese año, en La Stampa, una de las Storie di Vigàta e dintorni de Andrea Camilleri, titulada "Uno strano scambio di persona", que nos devuelve una vez más «al tiempo de la Guerra de España». ${ }^{60}$

59 Cfr. Lucarelli, Guernica, Il Minotauro, Milán, 1996, y luego, col. Tascabili-Stile Libero, Einaudi, Turín, 2000 (Guernica, trad. Miquel Edo, Edhasa, Barcelona, 2000); Pierre Magnan, «Guernica» (1991), en Les Secrets de Laviolette, Denoël, París, 1992 y posteriormente en la col. Folio Policier de Gallimard, París, 1999, pp. 77-152, con trad. italiana de Mariella Aleggiani en Guernica, Biblioteca del Vascello, Roma, 1994, y Robin, Roma, 2001. Por otro lado, aparte el juego de fechas para identificar posibles fuentes del género, el texto del autor italiano ha conocido también una traducción en francés, fruto, creo, de un interés por el noir y por los novelistas italianos que lo frecuentan, más que por el tema en sí, la guerra civil española y la ciudad herida del título. Aun cuando, justo es recordarlo, Guernica no se publicó en aquella Série Noire de Gallimard que ya había dado dos títulos lucarellianos (Phalange armée, Le Jour du loup): cfr. Lucarelli, Guernica, trad. Arlette Lauterbach, Gallimard, París, 1998.

60 Estos dos últimos textos pueden leerse en los mencionados diarios, pero están igualmente disponibles en red: <http://www.massimocarlotto.it/racconto1.html>, y <http://www.massimocarlotto.it/racconto1b.html>. <http://www.vigata.org/rassegna_stampa/ 2000/Archivio/Cunto02_Cam_ago2000_Sta.htm>. Cfr., en fin, el tebeo extraído del cuento de Carlotto - con su colaboración - por Giuseppe Palumbo, L'ultimo treno, Edizioni BD, Scandiano (Reggio Emilia), 2003, quien también firma, p. 3, un texto que comprende guión y dibujos: «Pasaron. Dedicado a José Ortega» y la traducción en imágenes de la «Historia» del coautor, cuyo relato se recoge en las pp. 47-48. 
En 2001 L'angelo della storia, de Bruno Arpaia, ${ }^{61}$ es publicada por Guanda, que en 2002 reedita, del mismo autor, Tempo perso, su novela anterior, publicada en 1997 por Tropea. Tiempo perdido está más conseguida que El ángel de la historia, pero se centra en la revolución de Asturias, en 1934, no propiamente en la guerra civil. Por supuesto, Tiempo perdido se conecta, por sus personajes y desarrollo narrativo, con El ángel de la historia, que desemboca en la Guerra de España, y obviamente contiene anuncios en tal sentido desde las primeras páginas; páginas a las que se asoma un testigo de excepción, Laureano Mahojo, nacido en 1916, localizado en México y al que el joven novelista, que «a ojo de buen cubero está del lado bueno», ${ }^{62}$ pide que hable del coprotagonista del libro siguiente, Walter Benjamin, nacido en 1892.

¿Qué es lo que me preguntaba? No, no. Yo he conocido después a su alemán, sería septiembre del 40, en la cima de los Pirineos, en la frontera entre Cataluña y Francia. Ya llego... No le estaré aburriendo, ¿no? Es que eran años intensos: el final de la monarquía, y luego las elecciones del 31... Las ganamos a lo grande $[\ldots]$.

Ya sé que son historias inútiles. Usted viene desde Italia, ha hecho no sé cuántos kilómetros para encontrarme y pedirme noticias de ese filósofo suyo, y yo le cuento mi vida, le hago perder tiempo... Tiene que perdonarme... [...] La verdad es que el 26 de octubre cumplo sesenta y ocho años [...] ¿¿Sabe qué es lo que tengo? El mal del tiempo [...].

No había tiempo de ocuparse de nada, parecía que toda la sarna del universo se hubiese dado cita en España, así, solo para joder a la República y al gobierno. Si mirabas alrededor, no había nada por lo que estar alegre. La derecha se reorganizaba, crecía de prisa delante de nuestros ojos. Yo no es que estuviera muy preocupado... Tenía dieciséis años, ¿qué quiere usted?63

Las experiencias narrativas de Tiempo perdido y El ángel de la historia se juegan en dos tiempos novelescos: el presente de la investigación, las fuentes y el certero, simpático testigo, y el pasado de la "puesta en escena». Pero, en Tiempo perdido, la aventura de Walter Benjamin no despega y en cierto sentido es mejor así, como veremos más adelante. Mientras, las páginas de El ángel de la historia alcanzan a alternar y entrecruzar, entre crónica e invención, dos hombres diferentes, el filósofo Benjamin y el tes-

61 Bruno Arpaia, L'angelo della storia, Guanda, Parma, 2001; cfr. del mismo autor, Tempo perso, Tropea, Milán, 1997 y luego en Guanda, Parma, 2002 (Tiempo perdido, Ediciones B, Barcelona, 1999).

62 Arpaia, Tempo perso (1997), cit., p. 7 (y p. 13 para la promoción de Laureano).

63 Ib., pp. 10, 12, 14. 


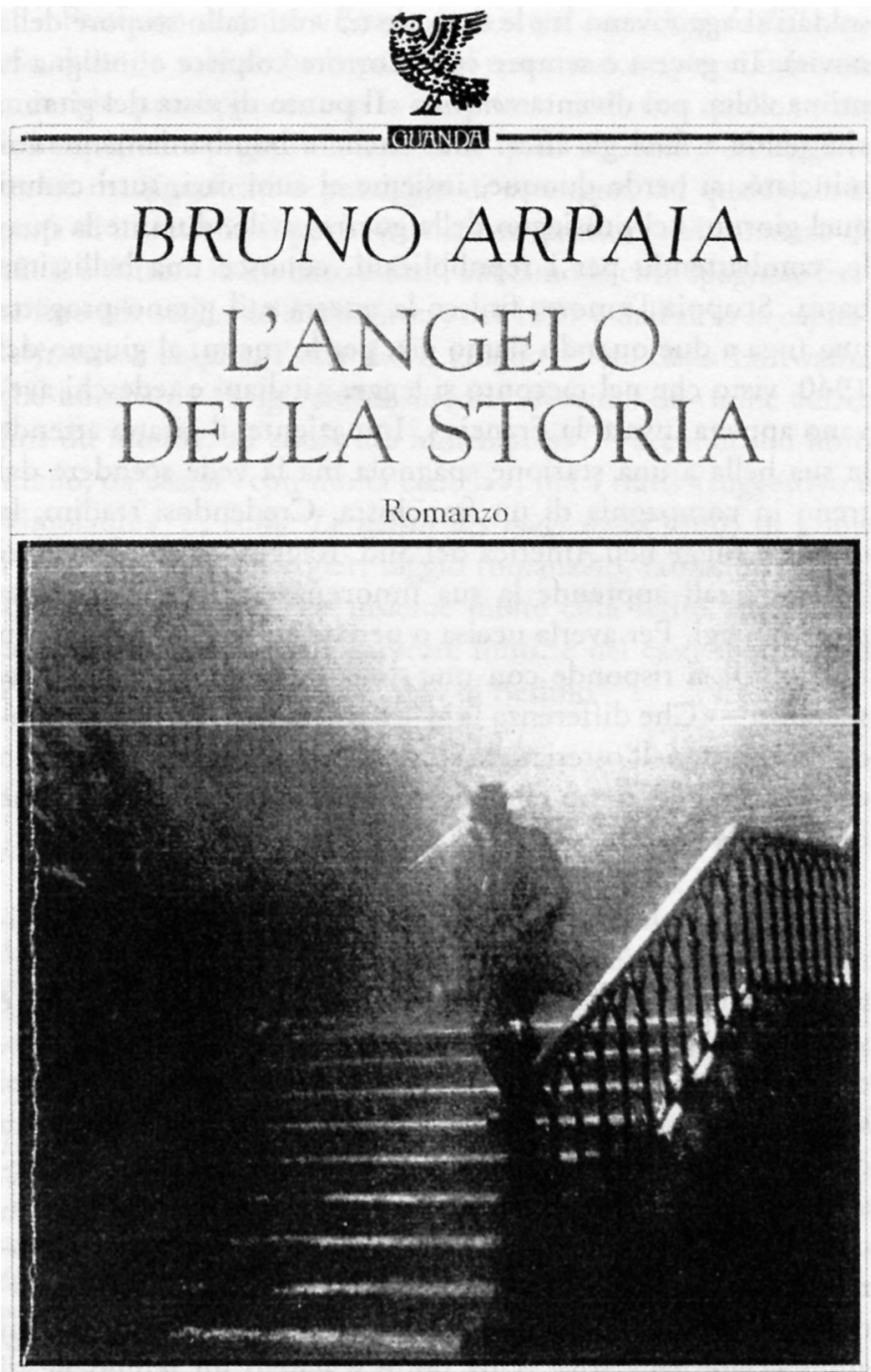




\section{Bruno Arpaia}
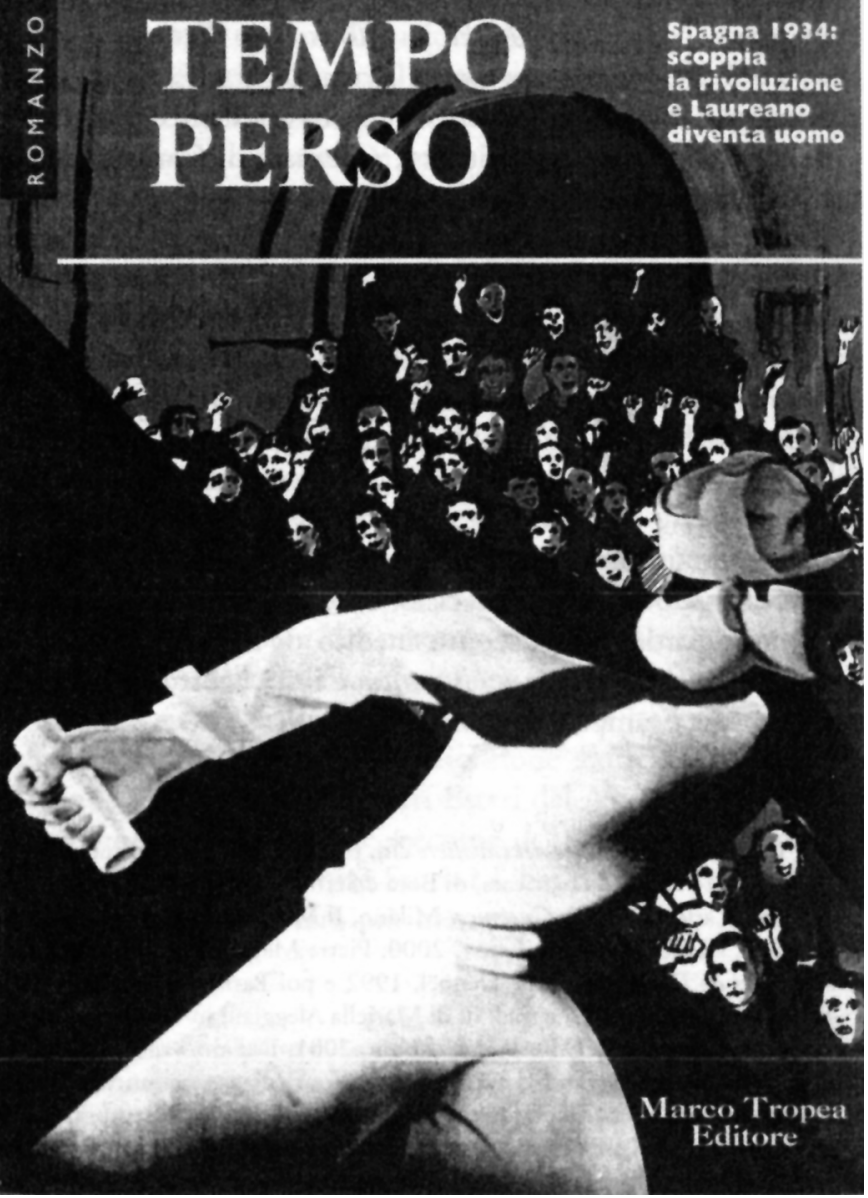
tigo Mahojo, un intelectual y un combatiente republicano, un hombre de acción; ese «hombre de acción» que tal vez "es un escritor frustrado», ${ }^{64}$ según Cercas (y Hemingway) y que Arpaia, por el contrario, tiende a oponer, con distinto resultado, al crítico alemán, jugando con el tándem, un tanto trivial a veces, «cuerpo y cerebro», "acción y estudio».

Cerrando casi el decenio antes indicado, Einaudi publica en octubre de 2001 Guerra di infanzia e di Spagna de Fabrizia Ramondino, poderosa, importante novela, por encima incluso del dato histórico y temático que aquí más nos interesa, la guerra civil española y sus ciudades heridas. ${ }^{65}$ Una novela de ambientación mallorquina que recuerda a Bernanos, como decíamos, pero que también trae a la mente — por la isla, el filtro de la infancia, el cuadro histórico, la segunda mitad de los años treinta, las referencias a la Guerra de España, la estructura en breves capítulos agrupados por partes - El tigre en la vitrina, primer libro de Alki Zei, que sale en Francia en 1963, cuando Grecia está bajo la dictadura de los coroneles, y Einaudi lo propone solo en 1978, si no me equivoco. En ese sentido, El tigre en la vitrina podría ser una reminiscencia fuerte, acaso en paralelo a una lectura de las Storie di patio que Ramondino publica en 1983 (Historias de patio, traducción de José Luis Checa, Alfaguara, Madrid, 1992), punto de partida de Guerra de infancia y de España, sobre la que tendremos ocasión de volver.

En El tigre en la vitrina estamos en una isla griega, agosto de 1936, y detrás de los juegos y fantasías de dos niñas, Melia y Myrto, fascinadas por un tigre de paja, se perfila el drama histórico del fascismo: drama de una época, difuso, extenso, pero también el que Grecia vive repetidas veces, entre los ańos treinta y sesenta, primero con la vuelta del rey Jorge II, que confía el gobierno al general Metaxas, el cual, de 1936 a 1941, instaura una dictadura de tipo fascista y hace de todo para aproximarse a las potencias del Eje, y luego con los citados coroneles. Es realmente significativo,

64 Cercas, Soldati di Salamina, cit., p. 151.

65 También en 2001, y siempre más allá de esa circunstancia pero dentro de la vuelta al periodo fascista que se produce en la narrativa italiana, con el significativo pendant de Etiopía, si bien, en la posguerra, podemos pensar en Davide Longo, Un mattino a Irgalem, Marcos y Marcos, Milán, 2001. Cfr. asimismo Andrea Camilleri, La presa di Macallè, Sellerio, Palermo, 2003 (La captura de Macalé, trad. María Antonia Menini, Salamandra, Barcelona, 2005). 


\section{FABRIZIA RAMONDINO \\ GUERRA DI INFANZIA E DI SPAGNA}

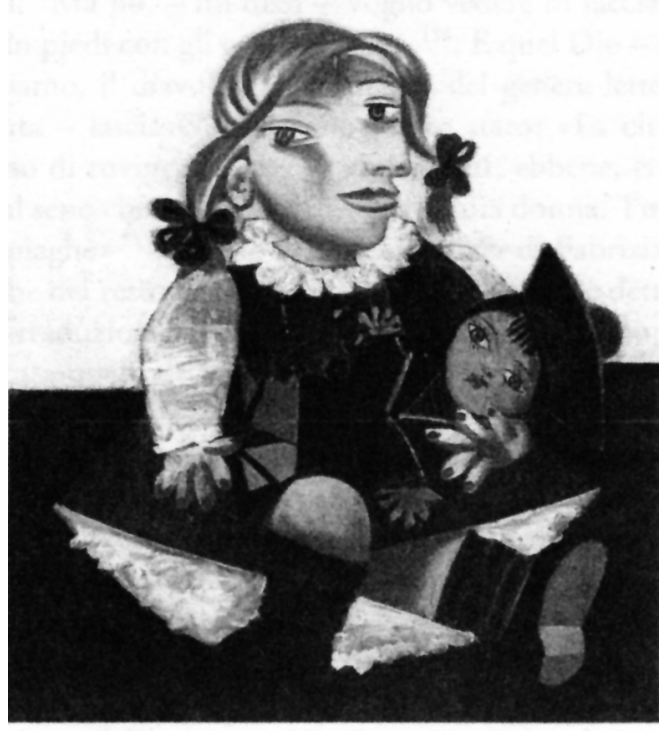

EINAUDI 
entonces, el hecho de que la Guerra de Espańa se asome al texto y al final confirme la voluntad del primo Nikos, estudiante en Atenas, de batirse en ese lejano país, como se lee en el capítulo «El canario y España. Estrellas y cangrejos. Si hubiese nacido escritora», ${ }^{66}$ que cierra la última parte del libro.

Se palpó en los bolsillos y sacó una carta [...] de Nikos. [primo de las nińas, cada verano de visita en la isla].

"Queridas primitas, he montado en el tigre para ir a España. Recordaréis que os he dicho que allí hay guerra. Voy para luchar al lado de los que cantan. Un día volveré, iremos juntos a Lamagari, el lugar más bello del mundo, y os contaré todas las aventuras que nos hayan sucedido, al tigre y a mí. Quered siempre a los niños de Lamagari. ¡Hasta pronto, niñas mías!».

- ¿Y si llamásemos España al canario?

—Qué tontería — dijo Myrto—. No es un nombre de pájaro. ${ }^{67}$

Es notable, en definitiva, el paralelismo con Guerra de infancia y de España y ciertos insertos «autobiográficos» desplegados en "temas recurrentes» de la narrativa de Fabrizia Ramondino: «la infancia, la marginación, el exilio", en los delicados y reveladores rescates de las primeras Historias de patio (1983) y en los curiosos vaivenes, casi insolentes, de los puntos de vista infantiles.

Se trata, para Ramondino, de niños y niñas en contacto con realidades geográficas lejanas pero acercadas por la historia personal y colectiva, dispersa incluso, retrospectivamente, entre los siglos XIX y XX, entre paisajes españoles y napolitanos, con «viejas casas agredidas por la guerra, donde se amasan familias venidas de distintos lugares»; ${ }^{68}$ niñas y niños que tienen una relación fabulosa con presencias casi arquetípicas, como la de la abuela, que sigue siendo una criatura terrena, concreta, más que la madre, y cuyas características pueden recordar las que asume la figura, el personaje de la abuela en la primera parte de Ballata levantina (1961), de Fausta Cialente. ${ }^{69}$

66 Alki Zei, La tigre in vetrina (1963), col. Nuovi Coralli, Einaudi, Turín, 1978, pp. 167-174.

67 Ib., p. 170.

68 Cito por la nota de solapa de Natalia Ginzburg a Ramondino, Storie di patio, Einaudi, Turín, 1983.

69 Fausta Cialente, Ballata levantina, Feltrinelli, Milán, 1961 y ahora, con pról. de Franco Cordelli («Il suo meraviglioso comunismo») y epílogo de Paolo Terni, Baldini e Castoldi, Milán, 2003; la primera parte se titula, precisamente, «La abuela», pp. 17-105. 
Pero invocamos aquí Guerra de infancia y de España sobre todo por un capítulo, "Historia del niño de Guernica», ${ }^{70}$ con el que concluimos nuestra argumentación, llegando una vez más a una ciudad herida cuyo triste destino sacude el imaginario infantil y mallorquín de la novela y sintoniza simbólica, funcionalmente con el desarrollo de esta, por lo que rinde la agresión en el plano literario y universal y por cómo está construida la estructura narrativa.

\section{Apuntes sobre el regreso de la guerra civil española en otros narradores italianos y extranjeros (traducciones, entrevistas, recensiones)}

Si queremos ir resueltamente más allá de 2001 y aventurarnos en los últimos años, entre 2002 y 2006, tratando de añadir un lustro al arco cronológico del que nos hemos servido, en concreto, para nuestra primera reseña hipotética, es fácil darse cuenta de que la guerra civil española sigue circulando en la narrativa italiana y en la extranjera, con traducciones, entrevistas y recensiones que a menudo la proponen al público italiano, apuntando precisamente a la vuelta de ese evento histórico, gracias también a su septuagésimo aniversario (1936-2006).

Pero es ciertamente difícil distinguir y aquilatar en un cuadro de conjunto la novedad y la fuerza de los nuevos textos, italianos y extranjeros, valorando acaso, a toda prisa, su posible impacto en los lectores, incluso en aquellos comprometidos (la guerra civil española como sinónimo de engagement, todavía un estímulo para luchar), y en el mercado editorial, incluso el no comprometido (la guerra civil española es un argumento que vende - aniversarios, afinidad con otras guerras civiles, o porque la guerra vende tout court - y, como tal, hay que explotarlo). Obviamente, la distinción no se sostiene: intervienen muchos otros factores, cada vez más numerosos e imprevisibles, cada vez más rápidos, que modifican la situación.

Para intentar poner un poco de orden en estos apuntes - que buscan la emergencia de autores extranjeros ya citados, junto con otros, pero sin afán de exhaustividad-, empezaremos por distinguir las últimas aporta-

70 Ramondino, Guerra d'infanzia e di Spagna, cit., pp. 199-208. 
ciones de los narradores italianos y las novedades que provienen del extranjero, para concluir con un rápido apéndice dedicado al florecimiento de testimonios, diarios y estudios históricos.

Por lo que respecta a las letras italianas, la guerra civil española es una presencia explícita en el capítulo VII, en concreto, de La domenica di questa vita, primera novela del italianista Alberto Casadei, publicada por la editorial Manni, de Lecce, en junio de 2002, donde — partiendo de una Romaña a un tiempo histórica ${ }^{71}$ e inventada y de una estructura semejante a la de Ken Loach pero sin "doble» salto generacional (es decir, no abuelo-nieto, sino padre-hijo) — se hace referencia a «un paisaje impreciso, sembrado de casas destruidas por bombardeos de la aviación italiana o alemana»: «Aldo se detuvo a pensar en su padre marchando por aquellas tierras martirizadas, aterrorizadas, semidestruidas, en las que se veía asesinado todo ser vivo, y en las que encima algunos creían estar viviendo una realidad más bella que la leyenda [...] Pero la violencia se multiplicó indefinidamente, y los bombardeos aéreos, la destrucción traída por las escuadrillas de la maravillosa aviación legionaria, que ellos miraban desde lejos, y luego he aquí el fuego que avanza $[\ldots]{ }^{72}$

De modo implícito, en cambio, parece que la guerra civil española se insinúe en Senza sangue, de Alessandro Baricco, editada por Rizzoli en agosto de 2002, donde los dos tiempos narrativos — separados por cincuenta, sesenta años, como ha sugerido Angelo Morino en L'Indicereúnen también, respectivamente, "un paisaje desfigurado por años y ańos de guerra feroz» y Santander, «ciudad del presente» quizás: «ciudad espańola de la zona cantábrica, asomada al golfo de Vizcaya» que alberga, terminada la guerra y a más de medio siglo de distancia, las señales todavía no desaparecidas del horror, con una casa de reposo que parece tomar el relevo de un hospital acondicionado como centro de torturas

71 Para la histórica cfr., por ejemplo, lo que dice Giorgio Giovagnoli sobre la Guerra de Espańa en su Storia del partito comunista nel riminese 1921-1940, pról. Giancarlo Pajetta, Maggioli, Rímini, 1981, pp. 326-338.

72 Alberto Casadei, La domenica di questa vita, Manni, Lecce, 2002, pp. 71 y 75. Como crítico Casadei se ha ocupado de la guerra, tema al que ha dedicado dos trabajos: La guerra, col. Alfabeto Letterario, Laterza, Roma-Bari, 1999, y Romanzi di Finisterre. Narrazione della guerra e problemi del realismo, Carocci, Roma, 2000. 
durante los años de guerra ${ }^{73}$ (acordémonos del centro psiquiátrico militar en Las semanas del jardín [1997], de Goytisolo).

Digamos enseguida que el doble, bipartito espacio-tiempo narrativo (y lírico) de Baricco no conduce al novelesco de Arpaia, en Italia, y principalmente de Cercas, en Espańa. No solo debido a su buscada, deseada opacidad, que desde luego le aleja del «relato real» hacia el que Cercas y su álter ego en la novela empujan con insistencia la aventura humana de un escritor falangista de primera hora. Trata luego de escapar a las ambiguas trampas del esquematismo ideológico, evidentes, mediante una frase reiterada con variantes en el texto y confiada a un feliz personaje femenino, la mujer del álter ego. Esta mujer no cree en la potencialidad novelesca de una historia basada en un franquista y exclama: «Si no fuese porque sé que eres un intelectual, diría que eres tonto. ¿No te he dicho desde el principio que lo único que hay que hacer es escribir sobre un comunista?». ${ }^{74}$

Aparte de la boutade, es el título el que, en buena medida, indica el camino justo para tratar de entender y contar, hoy, un acontecimiento como la guerra civil española: Soldados de Salamina está pensando, de hecho, en un episodio de aquella aventura humana e histórica "como si el hecho no hubiese sucedido hace solo sesenta años, sino que se tratase de un evento tan remoto como la batalla de Salamina». ${ }^{75}$

Los cincuenta, sesenta años de Alessandro Baricco, pues, aunque transfigurados, pierden su significado frente a esta enormidad, que la memoria de Cercas (y acaso su moral, por muy «astuta» que sea) exige, sin recurrir a una "geografía falaz» ni siquiera a una exhibición estilística más o menos apreciable; en virtud de la cual, en Baricco, «hay que buscar lo representado más allá de las palabras y las imágenes inmediatamente percibidas, allí donde, a pesar de las apariencias, todo permanece, precisamente, inmóvil». ${ }^{76}$

De la rareza, de la página blanca, el silencio y la inmovilidad de Alessandro Baricco, podemos pasar entre 2002 y 2004 a un registro estilístico

73 Angelo Morino, «Una geografia fallace», L'Indice, 12, 2002, p. 15, a propósito precisamente de Alessandro Baricco, Senza sangue, Rizzoli, Milán, 2002 (Sin sangre, trad. Javier González Rovira, Anagrama, Barcelona, 2003).

74 Cercas, Soldati di Salamina, cit., p. 168.

75 Ib., p. 40.

76 Cfr. otra vez Angelo Morino, «Una geografia fallace», cit. 
completamente diferente pero dominado por una forma de narcisismo autoral igualmente evidente, la del palermitano Fulvio Abbate. La «fantasmagórica", excesiva novela Teledurruti (2002) anticipa en cierto sentido - no con la intensa recuperación de personajes y el desarrollo narrativo de Bruno Arpaia- ese «documental» dedicado a la memoria de la guerra civil española que es Il ministro anarchico (2004), según la faja de la cubierta: texto que no es un ensayo ni una biografia, sino, como sugiere Arpaia, aquí recensor, "una serie de "disparos"», de imágenes ligadas por el personalísimo viaje del escritor a través de vestigios, fotografías, viejas tumbas, recortes de periódico, documentos y testimonios de época». Las fotografías, que además retratan al propio Abbate, ${ }^{77}$ hacen pensar de nuevo en el viaje de Affinati en Un teologo contro Hitler. Sulle tracce di Dietrich Bonhoeffer (2002) pero rehecho, aparte de con las fotos, con la presencia un tanto extrema del autor, al punto de que Arpaia llega a decir justamente, al final de su recensión: "Tal vez en estas páginas hay un poco demasiado Fulvio Abbate y menos García Oliver de lo que sería deseable». Cunde la idea de que cierta docuficción italiana vaya continuamente a la busca del último olvidado o perdedor de la historia y de la Guerra de España, hasta encontrarlo a duras penas «tropezando con Ascaso, Durruti [ya en el texto de 2002] ${ }^{78}$ Abel Paz, Fernando Arrabal o Carlo Rosselli». ${ }^{79}$

77 Fulvio Abbate, Il ministro anarchico, Baldini Castoldi Dalai, Milán, 2004, pp. 11, $101,112$.

78 Teledurruti habla de un joven que funda una emisora privada, alternativa, y decide llamarla como Buenaventura Durruti. En un par de páginas, las razones de esta elección de Aldo Bologna, parado, emergen de modo "fantasmagórico»: «estaba el blanco y negro de las cebras salvadas por el trabajo humano; vino luego el color, radiante de arcoiris, como las portadas de Santana. Hasta que un día, sin avisar siquiera, las cartas de ajuste fueron abolidas. Pero en el medievo televisivo, cuando todavía existían, es verdad que se parecían al sueño del desempleado Aldo Bologna que, harto de su propia muerte civil, se ha echado a dormir sobre la yerba del cierre de la emisión, de todas las emisiones. Sí, las cartas de ajuste eran como las fotografías cerámicas de los muertos del cementerio: adiós, adiós, o mejor: adiós por el momento, pues seguramente mañana — sí, mańana, no hay dudaresurgiremos, estaremos de nuevo en vuestra casa, en la nuestra, delante de la verja, del portero automático; estamos muertos, es verdad, nos habéis puesto el traje oscuro, el mejor, y, efectivamente, con ese mismo traje resucitaremos, volveremos a la ciudad para poneros un culo así de grande: en nombre de Durruti y su revolución». Cfr. Abbate, Teledurruti, Baldini e Castoldi, Milán, 2002, pp. 30-31; léanse también las páginas siguientes, el diálogo entre Aldo y Stefania «en polo y braguitas».

79 Arpaia, "Giustizia accidentale di un ministro anarchico", suplemento Domenica del periódico Il Sole-24 Ore, 308, 2004, p. 39. No opina lo mismo Roberto Giulianelli (L'Indice, 9, 2005, p. 42), para quien ese "documental travestido de pesquisa» es un traba- 
Proponiendo distingos tan sutiles se puede caer en la ambigüedad. La trayectoria de Affinati, desde Campo del sangue (1997) hasta Compagni segreti. Storie di viaggi, bombe, scrittori (2006), ${ }^{80}$ pasando por Un teologo contro Hitler (2002), parece más sólida, convincente, sobre todo presidida por un discurso «secreto" sobre la pérdida de la función de la intelligentsia en la sociedad. ${ }^{81}$ Mientras que el iter de Abbate tiende abiertamente a explotar, en un nivel editorial, la curiosidad de una parte del público por figuras más o menos marginales, en las que pueda reflejarse el autor, primero, y luego el lector, sin abordar esas aproximaciones a una ética del lenguaje que constituyen, para nosotros, el fundamento de un tipo de recepción de la guerra civil española en la narrativa italiana. De este modo, aun cuando parezca declarar justo lo contrario, como sucede en Teledurruti, y como si fuera parte de una estrategia metanarrativa y prospectiva, Abbate enseña sus cartas: "pero esos le habrían propuesto seguramente una de esas cabronadas de moda. Servía igual el rostro de Buenaventura Durruti sacado de un documental: Durruti, gorra negra y roja en la cabeza, discutiendo con sus milicianos en la carretera de Zaragoza». ${ }^{82}$

En definitiva, el comienzo del siglo XXI confirmaría en parte algunas tendencias de los años noventa. Como he observado repetidas veces, ${ }^{83}$ la

jo apoyado en «una seria investigación histórica» dirigida a recoger y ordenar las «pistas» de García Oliver "con eficaz desorden». Cfr. Abbate, Il minitro anarchico, cit., que en las pp. 165-167 añade al texto una bibliografía y, tras los agradecimientos, un «In memoriam Juan García Oliver —y ¡viva Fulvio Abbate!», de Fernando Arrabal, pp. 171-179.

80 Eraldo Affinati, Campo del sangue, Mondadori, Milán, 1997 y Compagni segreti. Storie di viaggi, bombe, scrittori, Fandango, Roma, 2006. Véase la inteligente recensión de este último libro que hizo Giorgio Ficara, "Affinati, tutte le strade del mondo conducono al "campo del sangue"", ttL TuttoLibri, 1517, 2006, p. 4.

81 Cfr. Christian Delporte, Intellectuels et politique, Casterman/Giunti, Florencia, 1995, pp. 104-121. Me permito remitir también a Curreri, «Il ritorno di due "uomini contro": Campanella e Bonhoeffer in Maffia e Affinati", en Alain Sarrabayrouse y Christophe Mileschi (eds.), Lo Spazio della Religione e il Senso del Religioso nella Letteratura Narrativa Italiana Contemporanea (1970-2006), actas del congreso de Grenoble, 23-24 de noviembre de 2006, Cahiers d'Études Italiennes. Novecento... e dintorni, 8, 2009.

82 Abbate, Teledurruti, cit., p. 32.

83 Curreri, «Tra Madrid e Guernica. Guerra civile spagnola e città ferite nella narrativa italiana (1996-2002)», Cahiers d'Études Italiennes. Novecento... e dintorni, 1, 2004, pp. 175-202, y "Que peut la guerre d'Espagne dans le roman italien?», en Viviane Alary y Danielle Corrado (eds.), La Guerre d'Espagne en héritage: entre mémoire et oubli (de 1975 à nos jours), actas del congreso de Clermont-Ferrand, 10-12 de marzo de 2005, Presses Universitaires Blaise-Pascal, Clermont-Ferrand, 2007, pp. 259-270. 
Guerra de España es un telón de fondo, a menudo reducido a jirones, del que nos servimos de manera estereotipada, como hacemos en general con toda la historia, especialmente la moderna y la del siglo breve, atravesada cada vez más, incluso desde una perspectiva institucional, por las que podríamos llamar, con Ricuperati en su Apologia di un mestiere difficile. Problemi, insegnamenti e responsabilità della storia (2005), ${ }^{84}$ instancias narratológicas.

Instancias que, obviamente, son típicas sobre todo, desde siempre, del universo novelesco y cinematográfico, sin que tengan nada que ver $-\mathrm{O}$ muy poco- con una reflexión intelectual sobre las relaciones entre cultura y poder, como la contenida en El antimonio.

¿Por qué hablar de ellas, entonces, especialmente en un corte temporal que por sí mismo justificaría casi las mutaciones sobrevenidas, aun dentro de la mucha nostalgia por Sciascia y Pasolini que Tabucchi despliega en la dedicatoria de La gastritis de Platón (1997 y 1998)? Porque tales instancias pueden servirnos para introducir y entender mejor esa literatura que hoy — reaccionando estilísticamente contra la consecuencia extrema de esas instancias en ámbito novelesco, es decir, contra el fin de la historia y el uso público que de él hacen los gustos y la modas - trata de subrayar la transformación de las relaciones entre cultura y poder, que ya no es o no solo es poder político, sino, antes que nada, poder económico y mediático. En otras palabras: presión del mercado y de la sociedad; en algunos casos incluso sublimada y teórica. ${ }^{85}$

Las instancias narratológicas, en efecto, se abren a los seductores senderos de la fiction (y de la docuficción) y en el caso de la guerra civil espańola oscilan entre, por ejemplo, biografías noveladas (Tina, de Pino Cacucci), intrigas detectivescas y terroríficas (Guernica, de Carlo Lucare1li), ejercicios de escritura (Sin sangre, de Alessandro Baricco) y «documentales» travestidos de investigación (El ministro anarquista, de Fulvio Abbate). El reto, pues, o al menos una parte (importante) del reto, consiste en no hacer naufragar la escritura de la historia — tampoco la prosa

84 Ricuperati, Apologia di un mestiere difficile. Problemi, insegnamenti e responsabilità della storia, cit.

85 Ojéese Evangelisti, Distruggere Alphaville, L’Ancora del Mediterraneo, Nápoles, 2006; cfr. cómo lo destrozó A. Cortellessa, «Solo padre Dante più in alto del noir», TuttoLibri, 1519, 2006, p. 3. 
ensayística, narrativa, diarística que puede acompañarla y hasta traducirse en cine- en "una serie de relatos (escritos pero, sobre todo, audiovisuales) que tienen como único fin "dejarse leer"”, como sugiere Giovanni De Luna reseñando el citado libro de Ricuperati. ${ }^{86}$

Renunciar a este «dejarse leer» es ya un signo de compromiso, tal vez más para el novelista que para el historiador, que en última instancia puede salvarse de la tentación separando, con mayor o menor propiedad, su papel institucional de una eventual segunda piel de narrador y/o autor de novela histórica. Pero "dejarse leer», para un novelista, puede sonar también, por encima de modas y sentidos figurados, a imperativo, casi a imperativo ético: yo debo dejarme leer, debo hacer que los demás sean capaces de leerme. No quiere ello decir, obviamente, que se anule la reconquista crítica del problematismo, también ético, del pasado y se le haga coincidir con un simple divertimento.

Ante la Historia con hache mayúscula, que infunde temor, tanto acaso como la naturaleza leopardiana menos generosa, la historia de los últimos setenta o sesenta ańos, o del siglo breve, o de los siglos de la modernidad, la historia que nunca se detiene, que no ha terminado y que nos sobrevivirá, la historia que Manzoni tenía ante los ojos y con la que Nievo (y tantos otros después de él) tuvo que vérselas, frente a esta historia que no es una postal, un panorama, un telón de fondo, dos avisados narradores italianos de más edad, a saber, Claudio Magris y Antonio Tabucchi, parece que hayan decidido "no dejarse leer»; que "no se dejen leer» dos recientes novelas suyas -la magrisana $A$ ciegas (2005), la tabucchiana Tristano muere (2004) — que serían — aun dentro de una no negada subjetividad y una intimidad casi física, corpórea, especialmente en el caso de Tabucchi- la emanación colectiva y experimental de «una nueva política de la literatura» nacida en el Parlamento Internacional de Escritores de Estrasburgo, del que Magris y Tabucchi forman parte, y que se dirige a perfilar un testimonio como el de Diventare minoritari (2003). ${ }^{87}$

86 De Luna, "Davvero scrivere la storia è una "mission impossible"?», TuttoLibri, 1497, 2006, p. 7.

87 Christian Salmon y Joseph Hanimann, Diventare minoritari. Per una nuova politica della letteratura, seguido de Un parlamento immaginario? Conversazione con Salman Rushdie, Wole Soyinka e Russell Banks (2003), Bollati Boringhieri, Turín, 2004, pp. 31-49 y $90-107$. 
La conversación-entrevista de Joseph Hanimann, corresponsal del Frankfurter Allgemeine Zeitung, con Christian Salmon, fundador del citado parlamento, da lugar a un librito que reflexiona sobre la posthistoria del compromiso, es decir, sobre el engagement intelectual de la última década del siglo XX, que simbólicamente se hace empezar algún mes antes, en noviembre de 1989, con la caída del muro de Berlín, y concluye algún ańo después, en el amanecer trágicamente dilatado del siglo XXI, con el ataque a las Torres Gemelas de septiembre de 2001; ataque que es el dramático bautismo de los años que estamos viviendo y tratando de comentar mediante la recepción de la guerra civil española en la narrativa italiana (y no solo) - acaso conviene recordar otra vez el cortocircuito entre Guernica y Nueva York, del que hablaba André Glucksmann en 2002. ${ }^{88}$

La estrategia narrativa que planea el Parlamento Internacional de Escritores de Estrasburgo responde a un principio de diseminación y a una acústica que tiende a negar la enunciación, incluso como verdad, llegando a resquebrajar, exponencialmente, una credibilidad ya resquebrajada cuya herencia ha de gestionar. En el fondo, es casi una emanación de ella y podría aparecer como un gesto de renuncia y aristocrático, como un exilio dorado, demasiado fácil para quien sabe escribir, pero no es así, aunque puedan subsistir algunas dudas.

Yo diría que, de todas maneras, apostar por el relato, por la persistencia del relato, uniendo a la militancia de ser minoritarios el «no dejarse leer», significa, en el caso de Magris y Tabucchi, unir el interés por lo marginal, por el microcosmos, a la intromisión resquebrajada, y como tal restituida, de la historia, en cuanto encuentro-desencuentro de micro y macro en la época de Utopía y desencanto (1999). ${ }^{89}$

En relación con todo esto, exactamente diez años después de Sostiene Pereira (1994), ¿cómo situar Tristano muere (2004), «mosaico de minutos robados a la memoria sin orden ni cronología» y cuya "historia", sugiere

88 Cfr. de nuevo Glucksmann, Dostö̈evski à Manhattan, cit., pp. 18-24.

89 Claudio Magris, Utopia e disincanto. Saggi 1974-1998, Garzanti, Milán, 1999 (Utopia y desencanto: historias, esperanzas e ilusiones de la modernidad, trad. José Ángel González, Anagrama, Barcelona, 2004). También de Magris, cfr. La storia non è finita. Etica, politica, laicità, Garzanti, Milán, 2006. 
Luciana Stegagno Picchio, "no podemos pretender reconstruir»?90 ${ }^{90}$ cómo situar, respecto a Microcosmos (1997), con un similar corte temporal, al Magris de A ciegas (2005), en el que, como dice Vittorio Coletti, "los atestados de la cultura y de la historia son centrifugados» en un "torbellino [...] de melancolía y tristeza» y en un «delta estilístico laberíntico y tentacular»? ${ }^{21}$ Se diría que una suerte de traducción invertida, que se desplaza del «dejarse leer» al «no dejarse leer», como arriba los hemos entendido y brevemente delineado, dentro de una empresa cambiante, de un espacio de diseminación y de una determinada acústica, es una de las posibles vías que se nos ofrecen, también respecto a la Guerra de España y su herencia, que deja una extensa huella (sin desarrollo constante y lineal) en ambos textos - bien diferente de como lo hace en La misteriosa llama de la reina Loana (2004), de Eco. ${ }^{92}$

Magris ha vuelto recientemente a Espańa y su guerra civil con otra mirada, en cierto modo más magrisiana. Me refiero al libro que, a seis meses de distancia, sigue a $A$ ciegas: El infinito viajar aparece en octubre de 2005. Justo después del prólogo, que en parte podría constituir un análisis del texto o tout court una introducción a la novela anterior, ${ }^{93}$ encontramos — junto a artículos que se remontan a los años ochenta y

90 Stegagno Picchio, «Lui amò Rosamunda», cit.

91 Coletti, "Nel sangue della storia il narratore folle e il re d'Islanda», L'Indice, 9, 2005 , p. 15.

92 Tabucchi, Tristano muore, cit., pp. 40-41, 57, 60-65, 67, 70-73, 108, 111-114, 132-133 y 139; Magris, Alla cieca, Garzanti, Milán, 2005, pp. 13-14, 25-26, 34, 44-45, 68, 70, 120-122, 123, 129-130, 132-134, 144, 171, 215 y 304-305. Cfr. Umberto Eco, La misteriosa fiamma della regina Loana. Romanzo illustrato, Bompiani, Milán, 2004, y col. Libri d'Oro, 2005, pp. 44, 145-147, 151, 185, 191, 206-207, 210, 260 y 334 (La misteriosa llama de la reina Loana, trad. Helena Lozano, Lumen, Barcelona, 2005). Permítaseme remitir también a Curreri, "La sfida di non farsi leggere. Appunti intorno a Tristano muore (2004) di Tabucchi e Alla cieca (2005) di Magris», en Barwig y Stauder (eds.), Intellettuali italiani del secondo Novecento, cit.

93 Magris, pról. a L’infinito viaggiare, Mondadori, Milán, 2005, p. XV: «Lo real se revela probabilista, indeterminista, sujeto a repentinos colapsos cuánticos que hacen desparecer algunos de sus elementos, engullidos, chupados por remolinos del espacio-tiempo, molinillos de la mortalidad de todas las cosas, pero también de la imprevisible emergencia de nueva vida. [...]. Viajar significa ajustar cuentas con la realidad pero también con sus alternativas, con sus vacíos; con la Historia y con otra historia o historias impedidas y desplazadas por aquella, pero no completamente borradas»; cfr. antes las pp. VIII-IX, XII-XIII, XVIII-XX y XXVI-XXVII (El infinito viajar, trad. Pilar García Colmenarejo, Anagrama, Barcelona, 2008). 
noventa pero también posteriores al 2000— «Por el camino de Don Quijote» (2001). Pero a Don Quijote se sobrepone en seguida el Beatus Ille $(1986)^{94}$ de Antonio Muñoz Molina, donde el recuerdo de la guerra civil se abre camino poco a poco, en medio de saltos espacio-temporales no desencadenados por las "poleas Frullifer», ${ }^{95}$ sino por la fuerte tensión existencial del viaje, fruto a su vez, aunque no solo, de lecturas, de páginas de un libro: «Marionetas en Madrid», «El bibliófago», «En el mentidero», "Un padre, un hijo», "Spoon River en Cantabria», "El primer vuelo de don Serafín. ${ }^{96}$

Debido a la reciente apertura (y enriquecimiento) del tema y del mercado italiano a la producción novelesca española relativa a los años de la guerra civil y su entorno más o menos inmediato, conviene situarse - aun a riesgo, una vez más, de incurrir en juicios y repeticiones- en una perspectiva comparatista que trate de suscitar rápidas lecturas cruzadas de textos, incluso muy distintos y no solo por sus resultados artísticos y comerciales.

De Las semanas del jardin (1997) de Juan Goytisolo podemos pasar a José Ovejero y su Añoranza del héroe (1997), de ambientación cubana pero con la guerra civil española en primer plano. Rosa Montero la define «una novela antropófaga, en la que el lector es devorado por sus páginas y se precipita en la historia [...] junto con el protagonista, Neftalí Larraga, personaje mísero y grandioso». Definición que dirige al autor María Pilar Soria Millán, ${ }^{97}$ en una entrevista aparecida en el periódico Il Manifesto en 2005, y a la que Ovejero replica reflexionando sobre el azar y los viajes que son la base de su trabajo, fruto de conversaciones y auténticas entrevistas, que en ocasiones recuerdan — más allá de la amplitud de la descripciónEl hijo de Bakunin (1991), de Atzeni, especialmente en las primeras pági-

94 Antonio Muñoz Molina, Beatus ille, Seix Barral, Barcelona, 1986. Sobre la importancia de esta novela, "menos comentada que las siguientes novelas del autor», cfr. M. Bertrand de Muñoz, La guerra civile spagnola nel romanzo, nel teatro e nel cinema dopo la morte di Franco, cit., pp. 155-156.

95 Evangelisti, Nicolas Eymerich, inquisitore, cit.

96 Magris, L’infinito viaggiare, cit., pp. 1-30

97 María Pilar Soria Millán, «Ideali perduti nei viaggi di José Ovejero», Il Manifesto, sábado 30 de abril de 2005, p. 13. 
nas: ${ }^{98}$ "Exceptuando el hecho autobiográfico de que mi familia viva en Cuba, lo demás ha sido una casualidad. Iba y venía de la isla a Bélgica; con el tiempo he querido conocer a las personas que han participado en la revolución, y a los cubanos que han tomado parte en la guerra civil espańola. [...]. Parte de este material aparece en la historia de Ramón, que va en busca de su abuelo Neftalí. Las entrevistas que he puesto en el libro las he hecho realmente, no son ficticias, y el mismo contenido de la novela nace de conversaciones con personas del lugar, y con mi familia. Con Añoranza del héroe quería contar la historia de un hombre considerado, injustamente, un antihéroe: creía haber escrito un libro sobre la caída de los ideales, pero ha sido más bien la realidad la que se ha desmoronado».

Casi parece que estuviéramos oyendo a Magris en $A$ ciegas o en el prólogo de El infinito viajar. Está claro que, aparte del dato, ahora extendido y transmitido de unos a otros, de la caída de los ideales - y del final de las ideologías, a menudo confundidas con aquellos- que se convierte en desmoronamiento de la realidad, la guerra civil española vuelve en muchos relatos gracias, sobre todo, al extraordinario éxito de Soldados de Salamina (2001), de Cercas.

Y desde el tantas veces citado Soldados de Salamina es oportuno arribar a ;Esa luz! (2000), de Carlos Saura, para recordar que el famoso director - ya implicado en otras evocaciones cinematográficas (y no solo) de la guerra civil -99 elige debutar como novelista significativamente con una

98 José Ovejero, Nostalgia dell'eroe (1997), trad. Barbara Bertoni, Voland, Roma, 2005, p. 9: "Tal vez Neftalí Larraga no era un hombre valiente. Que en algunos momentos de su vida se hubiese comportado como un héroe podía depender incluso de cierta debilidad de carácter. [...]. Muy probablemente la historia de Neftalí habría acabado en el olvido si Ramón, uno de sus nietos, no se hubiese obstinado en seguir la pista de ese individuo del que nunca se hablaba en casa. Al principio fue solo curiosidad lo que le empujó a indagar sobre el abuelo, tema tabú en la familia, del que apenas sabía que había sido un revolucionario cubano y que había combatido en la guerra civil española». Cfr. también las pp. 10-15 y 47-52. (El título original es Añoranza del héroe, Destino, Barcelona, 1997.)

99 Véanse al menos las dos presentaciones que hace, dentro de un nutrido contexto, Marcel Oms, La Guerre d'Espagne au cinéma, cit., pp. 219-220, 288-291, que también ha cuidado la edición de Recuerdos de la guerra civil de Saura en M. Oms, Carlos Saura, Édilig, París, 1981. Doy solo algunas citas de las pp. 219-220 y 289 de La guerre d'Espagne au cinéma: «Solo en 1973, con La prima Angélica, es cuando Carlos Saura mostrará, desde el punto de vista de un vencido, su memoria de la guerra, reconstruyendo los bombardeos sobre Barcelona de 1939 [...] y describiendo comportamientos identificables como "fran- 
historia de amor que empieza, una vez más, en 1936, en España, con la guerra sacudiendo las existencias de Diego, periodista y escritor ya famoso a sus treinta ańos, y Teresa; dos vidas narradas por entre Madrid, los bombardeos, la provincia y el frente, con los caracteres cursivos que salvaguardan una herencia, un cierto punto de vista sobre el mundo, una interioridad que puede vacilar, «desmoronarse», $y$, en letra redonda, una narración más distendida, despegada, sustancialmente omnisciente. ${ }^{100}$

Un tren que parece coger también, desde el principio, Antonio Soler en El nombre que ahora digo (1999 y traducida en 2003), historia de amor apasionado entre Gustavo y Serena contra el fondo auténtico, humano, perdido de la guerra civil, de un Madrid agonizante. Una guerra lejana como la de Cercas (y acaso la de Koestler en Los gadiadores), pero menos literaria (y antigua); una guerra que no hay que alejar demasiado y de modo artificial, sino que debe ser traída al presente, al hoy, a partir no de periodistas y escritores sino de personajes decididamente marginales, saltimbanquis, enamorados de la vida en la muerte de la guerra: "Ahora sé quiénes fueron de verdad aquellos hombres que combatieron una guerra lejana [...]. Sé cuáles fueron los deseos y los temores de aquella gente, pero sobre todo conozco lo que se escondía tras la mirada de Gustavo Sintora [...] Serena Vergara [...] Nadie hablaba y a nadie le importaba Gustavo Sintora ni cómo había llegado a Madrid. No era más que una pajita que flotaba en la marea enloquecida de la guerra [...] huyendo de Málaga. Muebles, palanganas, un piano, animales, colchones, niños y soldados que viajaban a paso lento sobre los remolques rebosantes de los camiones. Baúles desventrados, sillas y muertos por la

quistas”. [...]. Antes de La prima Angélica, Carlos Saura había descrito metafóricamente en La caza (La Chasse, 1965) las actitudes de los vencedores. Una secuencia de exterminio de conejos en campo raso remite muy explícitamente a otros fusilamientos. [...]. Por último, en El jardin de las delicias (1970), una pantalla en la que se proyectaban noticias de la guerra cede paso a un grupo de personas en armas que parecían surgir del pasado para despertar la memoria dormida del personaje central»; «Tras la muerte de Franco (1975), la óptica del cineasta cambia y su proyecto desemboca finalmente en esa especie de salto creativo extraordinario que es Dulces horas (1982), donde se mezclan [...] lo vivido y su representación, lo real y su puesta en escena, donde la cronología misma parece desarticulada». En esta perspectiva se insertan otras obras de Carlos Saura (Ay, Carmela, de 1990) y, por lo que aquí nos interesa, también la novela a que aludimos brevemente.

100 Cfr. Saura, Quella luce, trad. Paola Tomasinelli, Einaudi, Turín, 2002 (;Esa luz!, Galaxia Gutenberg, Círculo de Lectores, Barcelona, 2000). 
calle». Así empieza la odisea de Sintora, que "había perdido la familia bajo un bombardeo" y encuentra una nueva, de "toreros y artistas [...] enanos equilibristas». ${ }^{101}$

Y del mundo apasionado y funambulesco de Antonio Soler podemos tal vez desplazarnos a Tu rostro mañana. 1, Fiebre y lanza (2002, traducida en 2003) de Javier Marías, docente universitario que en su décima novela da vida - un poco como Cercas, otro profesor de universidad - a un "narrador, que a fin de cuentas es el propio Marías, aunque sea bajo otros nombres y funciones», pero que con dolida consciencia e implicación dramática «revive algo que le pertenece, es decir, el clima de la guerra civil española». ${ }^{102}$ Más allá de la misma novela, acogida en Espańa de modo entusiasta y compacto pero dividiendo a críticos y recensores, ${ }^{103}$ es oportuno consignar lo que escribe Marías en el momento de la publicación de Tu rostro mañana: "Cuando a menudo escucho decir que ya es hora de superar el asunto de la guerra, creo que eso no puede ocurrir fácilmente. De niño he oído contar horribles atrocidades, y me rebelo cuando se es frívolo con esto. Cuando digo frívolo me refiero al modo sentimental, blando, adulador del que ha sido objeto y continúa siéndolo esta guerra, o bien episodios concretos de ella. Hay cosas que necesitan tiempo para convertirse en material novelesco, más o menos evidente. La guerra civil todavía la estamos vivendo. La vida de mi padre, por decir algo, se ha visto reducida y limitada, porque había pertenecido al bando republicano. $\mathrm{Y}$ así ha sucedido a muchos que han sufrido directamente la guerra, primero, y luego el franquismo». ${ }^{104}$

101 Cfr. Antonio Soler, Il nome che ora dico, trad. Tomasinelli, Marco Tropea, Milán, 2003, pp. 7, 12-13 y 15-16. (El nombre que ahora digo, Espasa-Calpe, Madrid, 1999). Cfr. la bella, entusiasta reseña de Paolo Collo, "Amore e guerra nella Madrid morente», ttL TuttoLibri, 1397, 2004, p. 3.

102 Cito por Angela Bianchini, "Marías a Oxford. Echi di guerra civile», ttL TuttoLibri, 1382, 2003, p. 3, recensión de Javier Marías, Il tuo volto domani, 1. Febbre e lancia, trad. Glauco Felici, Einaudi, Turín, 2003 (Tu rostro mañana, 1. Fiebre y lanza, Círculo de Lectores, Madrid, 2003).

103 Para ejemplificar brevemente la reacción de la prensa me sirvo, por un lado, de la recién citada Angela Bianchini, favorable, y por otro de una reseńa bastante dura de Danilo Manera, "Un'orgia di parole», L'Indice, 3, 2003, p. 17.

104 Cfr. Bianchini, "Marías a Oxford. Echi di guerra civile», cit. Cfr. en cambio lo que dice, favorablemente, sobre la decisión de dejar de lado el pasado (guerra civil y franquismo) Víctor Pérez-Díaz, La lezione spagnola. Società civile, politica e legalità (1999), ed. Michele Salvati, Il Mulino, Bolonia, 2003; Carmelo Adagio y Alfonso Botti, Storia della Spagna democratica. Da Franco a Zapatero, Bruno Mondadori, Milán, 2006. 
Y, claro, relativamente de acuerdo está el texto, más accesible, de Veinte años y un día (2003, traducido en 2005) de Jorge Semprún, ${ }^{105}$ título que indica la condena de los derrotados: el exilio y un ritual de muerte de verano en verano, de 1936 a 1956, como una melodía de fondo que recordase la pena y la derrota de todos. Con el regreso y el relato repetitivo de un Hemingway socarrón que balbucea «entre dientes su monólogo» con «inconfundibile acento yanqui».

"Nuestra guerra», había dicho Hemingway. "Decís todos lo mismo. Como si fuese la única; lo más importante, al menos, de cuanto podéis compartir. El pan vuestro de cada día...».

$[\ldots]$

"Nuestra guerra», balbucía. «Decís todos lo mismo. Como si fuese la única; lo más importante, al menos, de cuanto podéis compartir. El pan vuestro de cada día... La muerte, eso es lo que os une, la muerte antigua de la guerra civil».

Pero los yankees son ahora intocables, y Hemingway, tal vez, más que ninguno. Un «aduanero» da un bote, «impotente»: «Un yanqui es siempre un yanqui; por lo tanto, intocable, ya fuera que hubiera estado con los rojos, con los blancos o con el mismo demonio». Y Hemingway se pone a hablar de nuevo, a charlar de la guerra civil, saliendo de su monólogo. Si no él directamente, por lo demás, hay quien lo hace por él: Jorge Semprún $\mathrm{o}$ - con una reconstrucción novelesca en varios volúmenes que se asemeja más a una curiosa galería de retratos que a la ironía «comprometida» de Veinte años y un dia - Dan Franck. Pienso en Libertad! (2004, traducido en 2005), segundo volumen de Les Aventuriers de l'art moderne —después de Bohèmes (1900-1930) y antes de Résistances (1940-1944) y Jazz (19451950)_, dedicado a los años de la revolución y la guerra civil española $(1931-1939) .{ }^{106}$

Vemos, pues, como se delinea un cuadro compuesto pero en crecimiento en el que imaginario novelesco y mercado editorial buscan y encuen-

105 Jorge Semprún, Ventanni e un giorno, trad. y notas de Roberta Bovaia, Passigli, Florencia, 2005; las citas que siguen corresponden a las pp. 9-11 (Veinte años y un dia, Tusquests, Barcelona, 2003).

106 Dan Franck, Les Aventuriers de l'art moderne (1931-1939), 2. Libertad!, Grasset et Fasquelle, París, 2004, y col. Le Livre de Poche, LGF, 2006, pp. 175-290, para ParísMadrid, y pp. 291-337, para Guernica. Cfr. Libertad!, trad. Antonia Tadini Perazzoli, Garzanti, Milán, 2005, pp. 145-236 y 237-273. (De todas las obras de Franck citadas solo está traducida, por Teresa Alonso-Lasheras, Bohemios, Ollero y Ramos, Madrid, 1999.) 
tran - con cierta facilidad (que no siempre ni inmediatamente se traduce en felicidad de resultados) — la memoria y la historia de la guerra civil de España. También en 2006, año en que escribo este libro, siguen saliendo traducciones, especialmente del español, de títulos más o menos importantes. Me limito a señalar los notables Los girasoles ciegos (2004, traducido en 2006), de Alberto Méndez, que vuelve a reflexionar sobre el «terrible sentido del intercambio de papeles entre vencedores y vencidos", y Enterrar a los muertos (2005, traducido en 2006), de Ignacio Martínez de Pisón, que recupera la figura de José Robles Pazos, amigo y traductor de John Dos Passos que llevaba una sección, "Libros yankis», en La Gaceta Literaria de Madrid, asesinado por comunistas de la NKVD y convertido en traidor; textos ambos volcados en italiano por Bruno Arpaia para editorial Guanda. ${ }^{107}$

Una vez más, junto a diarios, testimonios, estudios históricos, ${ }^{108}$ que podemos rápidamente evocar en texto principal y notas — siempre a modo de ejemplo- a propósito de actualizaciones novelescas, para valorar en ese sentido el regreso o la aparición de algunos de estos libros en el mercado: regreso o aparición funcionales también al panorama narrativo del cambio de siglo que aquí nos interesa y datables — restringiendo y a la vez acercando el campo de investigación- entre 1996 y 2006.

107 Ignacio Martínez de Pisón, Morte di un traduttore, trad. Bruno Arpaia, Guanda, Parma, 2006, p. 11 y pp. 61-83 (Enterrar a los muertos, Seix Barral, Barcelona, 2005); Alberto Méndez, I girasoli ciechi, trad. Bruno Arpaia, Guanda, Parma, 2006 (Los girasoles ciegos, Anagrama, Barcelona, 2004), con una reseña de Bianchini, «Dentro l'armadio della guerra civile», ttL TuttoLibri, 1518, 2006, p. 5.

108 Es justo remitir, siquiera sea en nota, a algún título que entre los siglos XX y XXI, en Francia e Italia, inédito o en reedición, ha reclamado significativamente la atención de lectores y especialistas sobre la guerra civil española y la trágica desparición de la democracia en Europa y en el mundo. Cfr., por ejemplo, Michel Papy (ed.), Les Espagnols et la guerre civile, Atlantica, Biarritz, 1999; Jean-François Berdah, La Démocratie assassinée. La République espagnole et les grandes puissances. 1931-1939, Berg, París, 2000 (La democracia asesinada: la República española y las grandes potencias, 1931-1936, trad. María José Furió, Crítica, Barcelona, 2002); Gabriel Jackson, La Repubblica spagnola e la guerra civile. 1931-1939, Net, Milán, 2003 (anteriormente en Il Saggiatore, Milán, 1967, que traducía The Spanish Republic and the Civil War. 1931-1939, Princeton University Press, Princeton, 1965) (La República española y la guerra civil, trad. Enrique de Obregón, Crítica, Barcelona, 1999); Gabriele Ranzato, L'eclissi della democrazia. La guerra civile spagnola e le sue origini, Bollati Boringhieri, Turín, 2004 (El eclipse de la democracia: la guerra civil española y sus origenes, 1931-1939, trad. Fernando Borrajo, Siglo XXI, Madrid, 2006); Bartolomé Bennassar, La guerra di Spagna. Una tragedia nazionale (2004), Einaudi, Turín, 2006 (El infierno fuimos nosotros: la guerra civil española (1936-1942), trads. Paloma Gómez y Núria Petit, Taurus, Madrid, 2005). 
Entre quienes trasladan a España ${ }^{109}$ la experiencia madurada midiéndose con el fascismo en Italia, citaría al menos a Aldo Morandi —que se halla en Moscú cuando estalla el conflicto-y su In nome della libertà. Diario della guerra di Spagna 1936-1939, editado en 2002 por Mursia, al cuidado de Pietro Ramella, pero sobre todo a Camillo Berneri y su Mussolini alla conquista delle Baleari, publicado hasta tres veces, entre 1937 y 1938, en español y francés, y hoy — desde febrero de 2002- disponible en italiano gracias al editor Giuseppe Galzerano de Casalvelino Scalo (Salerno), que presenta este estudio junto a Claudio Venza, profesor de Historia de España Contemporánea, que había ya editado un libro importante cual es Le passioni dellideologia. Cultura e società nella Spagna degli anni Trenta (1989). ${ }^{110}$

El estudio de Camillo Berneri puede revelarse útil para leer Guerra de infancia y de España de Fabrizia Ramondino, más allá de las «Breves noticias sobre la guerra civil española en Mallorca» recogidas en apéndice a la novela y extraídas del libro de Josep Massot i Muntaner, La guerra civil a Mallorca (1976), ${ }^{111}$ y sobre todo más allá del antecedente de culto sobre las Baleares, Los grandes cementerios bajo la luna (1938) de Georges Bernanos, que de todos modos cita Ramondino en el séptimo capítulo de la primera parte de su novela. ${ }^{112}$

109 Cfr. una vez más Serra, L'esteta armato. Il Poeta-Condottiero nell'Europa degli anni Trenta, cit., [pp. 121-146), p. 130.

110 Véanse respectivamente Aldo Morandi, In nome della libertà. Diario della guerra di Spagna 1936-1939, ed. Pietro Ramella, Mursia, Milán, 2002, pp. 25-30 y ss.; Camillo Berneri, Mussolini alla conquista delle Baleari, Galzerano, Casalvelino Scalo (Salerno), 2002, pp. 65-161; y Claudio Venza et al. (eds.), Le passioni dell'ideologia. Cultura e società nella Spagna degli anni Trenta, Editre, Trieste, 1989. De Giuseppe Galzerano es justo señalar también, además de su papel como editor, su libro dedicado a Vincenzo Perrone. Vita e lotte, esilio e morte dell'anarchico salernitano volontario della libertà in Spagna, Galzerano, Casalvelino Scalo (Salerno), 1999.

111 Cfr. también, del mismo Massot i Muntaner, El primer franquisme a Mallorca. Guerra civil, repressió, exili i represa cultural, Publicacions de l'Abadia de Montserrat (PAM), Barcelona, 1996. Léase la atenta recensión que del libro hizo Emanuela Sarti en Joan Armangué i Herrero (ed.), La ruta de les illes: de Mallorca a Sardenya, Arxiu de Tradicions, Càller (Cagliari), 2002, pp. 40-42.

112 Cfr. de nuevo Fabrizia Ramondino, Guerra d’infanzia e di Spagna, cit., pp. 415417 y 85 . El largo panfleto de Bernanos se reimprime constantemente en Francia y puede leerse en rústica, con su texto íntegro, en la col. Points de Seuil; la última edición italiana, si no yerro, es de Net, Milán, 2005 (que ha tomado el relevo de la que publicó Il Saggiatore, col. L'Arco, 1996) (Los grandes cementerios bajo la luna, trad. Juan S. Olmos, Alianza, Madrid, 1986). 


\section{Novelas, relatos y recorridos temáticos: Madrid, Guernica y otras ciudades heridas en la narrativa italiana}

Empecemos, pues, a leer una por una las novelas y relatos citados, siguiendo un orden cronológico pero tratando ahora de rastrear sus recorridos temáticos, centrados, precisamente, en Madrid, Guernica y otras ciudades heridas; recorridos en virtud de los cuales el conjunto identificado en nuestras hipótesis de reseña — siendo, evidentemente, diversos sus componentes - parecería "coagularse» y resistir más allá del texto concreto y del mismo juicio crítico.

Desde esta perspectiva de análisis, y aunque sea un relato que no nos convence, Guernica, de Lucarelli — con notas y poéticos epígrafes brechtianos y spenderianos y el cerrado enfrentamiento entre un oficial alemán y Picasso ( $-i$ Es usted quien ha hecho Guernica? — No, ustedes») - ${ }^{113}$ puede, de todas maneras, ser un útil punto de partida para seguir la parábola de la ciudad bombardeada —26 de abril de 1937- en la narrativa italiana de los últimos años. Además, ligando el iter novelesco a un recorrido urbano que desemboca en esa ciudad herida - de Teruel a Madrid, pasando por Sigüenza, y de Madrid a ese «contenedor» que es Guernica-,${ }^{114}$ Lucarelli ofrece un mapa en el que también, en posición central, está esa capital símbolo de todas las ciudades españolas heridas de la guerra, como ya dijimos. El mismo prólogo, por lo demás, la pone en seguida en evidencia, asociándole una fecha, 10 de abril de 1937, que anticipa significativamente el triste futuro de la ciudad vasca, ya imaginable a partir de Madrid. De hecho, la noche ofrece a la capital un «cielo oscuro» porque «tal vez las estrellas habían caído también, el día anterior, con las bombas de los stukas». En la misma página sigue, y no es casual, una evocación

113 Así responde Picasso a un oficial alemán que visita su estudio y delante del Guernica: «- ¿Lo ha hecho usted, maestro? - No, lo han hecho ustedes, con la Luftwaffe». Sobre la genealogía del cuadro y su valor como icono del siglo XX, cfr. al menos los trabajos de Jean-Louis Ferrier, De Picasso à Guernica. Généalogie d'un tableau, Denoël, París, 1985 y col. Pluriel, Hachette Littératures, París, 1998, para una ed. actualizada: véase el epílogo, seguido por un apéndice documental correspondiente a fines de abril e inicio de mayo de 1937, pp. 207-221, y Gijs van Hensbergen, Guernica. Biografia di un'icona del Novecento (2004), Il Saggiatore, Milán, 2006 (Guernica: la historia de un icono del siglo XX, trad. Francisco J. Ramos, Debate, Barcelona, 2005).

114 Cfr. de nuevo Southworth, La Destruction de Guernica. Journalisme diplomatie propagande et histoire, cit. 
de la legión Cóndor. Y justo después, en Teruel, el protagonista, el oportunista Filippo Stella, «borracho», va a vivir una noche casi igual, «entre truenos de la defensa antiaérea y relámpagos de trazadoras». ${ }^{115}$

Enrolado forzosamente en el CTV,* Stella tiene que ayudar, en calidad de asistente, al capitán Degl'Innocenti a encontrar «el cadáver de un amigo suyo, compañero de curso, alcanzado en el pecho por la metralla durante la batalla de Guadalajara», ${ }^{116}$ el teniente y noble Vittorio Emanuelli. Como se descubrirá poco a poco, este no ha muerto en absoluto, sino que se ha transformado en una especie de monstruo, de hombre lobo, que a grandes pasos se dirige hacia el horror de Guernica. Una luna llena, algún cráneo, algún grito o aullido, y la suerte está echada. La guerra civil proporciona un género, que se pasa revista a sí mismo en otro horizonte temporal, en el cual el destino de la ciudad herida, Guernica, hace de catalizador de todo el mal de la guerra - «entre los fascistas se dice que arrasarán el pueblo con uno de los bombardeos más duros que se hayan visto nunca. Será como si la guerra bajase del cielo sobre Guernica»—, pero también de todo el mal de la humanidad, transfigurada, monstruosa, que allí toma parte: «Ahora [Emanuelli] vaga por España, y sea un desertor, un loco asesino o el alma misma de la guerra, parece que esté apuntando sobre Guernica». ${ }^{117}$

Al final, antes aún de llegar a Guernica, o acaso en la misma Guernica, en un punto impreciso de España, del mundo herido, y en una espera dilatada y apocalíptica, los dos soldados, el capitán y su asistente, semejan (y no es casual) a los héroes de Cervantes, Don Quijote y Sancho Panza: "uno alto, delgado y a caballo, delirando con los brazos abiertos y una bacía de barbero en la cabeza, y el otro bajo, pequeñito y gordo, que le seguía a lomos de un mulo». ${ }^{118}$ Pero antes de este desenlace tragicómico, anotemos otras páginas bastante interesantes, si bien no todas relacionadas con el tema de las ciudades heridas, de las cuales conviene partir, acaso de

115 Lucarelli, Guernica, cit., pp. 5 y 13.

* N. de los T.: «Corpo Truppe Volontarie». El Cuerpo de Tropas Voluntarias, denominación acuñada en febrero de 1937, designa la fuerza militar enviada por Mussolini en apoyo de los sublevados contra la República.

116 Ib., pp. 12 y 17.

117 Ib., pp. 86 y 93.

118 Ib., p. 104 
esos «anillos infernales» que «señalan la carretera a Madrid»: «Por una rasgadura de la lona miraba yo la tierra de nadie [...] Había casas desventradas y sin techo, con vigas erizando las paredes como pelos tiesos de miedo y agujeros en puertas y ventanas, lo mismo que bocas y ojos desorbitados»; «Estaba en una iglesia, una pequeña capilla de campo, destruida por el fuego que la había replegado sobre sí misma». ${ }^{119}$ Y luego Madrid, entre la periferia y el centro, con sus habitantes y sus rondas: «Era casi de noche cuando llegamos a las puertas de Madrid, oscura por el apagón, negra y llena de escombros recortándose contra la penumbra rojiza del crepúculo. En las afueras ya no había casas y toda la gente estaba fuera, a pesar del toque de queda, en medio de la calle, lejos de las paredes amenazantes de las fachadas vacías [...] le hice notar que todos caminaban un poco curvados y más lentos, como si tuvieran siempre sobre los hombros algo de esos cascotes. [...]. En la ciudad las casas eran mejores y la gente estaba dentro, detrás de los retales, los sacos y las hojas de periódico que tapizaban las ventanas [...] conteníamos la respiración, aplastados contra la pared húmeda de un zaguán y en la Puerta del Sol, donde una bomba había excavado un cráter, evitamos por un soplo una ronda comunista». ${ }^{120}$

En otras páginas, más fáciles pero logradas, se pasa en cambio de la presencia de Pinocho - «juguete italiano» que también comparece en la novela de Ramondino- al desempleado que antes de ir como legionario a España hace de comparsa legionaria en la película Scipione l'Africano (1937) de Carmine Gallone -recordemos a Lajolo- y que prefiere, obviamente, la ficción a la realidad: «De momento, la paga es buena [...] y me enrolo [...]. Pero cuando desembarco en Málaga y me encuentro a los oficiales de Franco que nos saludan gritando Viva la muerte... ¡meteos en el culo viva la muerte! No contéis conmigo... Así que me mandan al calabozo». ${ }^{121}$ De este modo, Viva la muerte no resulta la "versión ibérica de la expresión italiana "Me ne frego!" [iMe importa un comino!]», como un editorial de Prospettive, la revista que dirigía Curzio Malaparte, quería hacernos creer al terminar la guerra, en «una suerte de romanticismo extraterritorial», según Aldo Garosci. ${ }^{122}$

$\begin{array}{ll}119 & \text { Ib., pp. } 65 \text { y } 71 . \\ 120 & \text { Ib., pp. } 73-74 . \\ 121 & \text { Ib., p. } 40 .\end{array}$

122 Aldo Garosci, Gli intellettuali e la guerra di Spagna, cit., p. 421. 
Para pasar al relato de Massimo Carlotto — aproximable, por la presencia de gitanos y otras características, a la novela, ciertamente más densa, de Soler — anotemos en seguida que su «forma breve» — aún más concentrada que la de Lucarelli- no deja estructuralmente espacio a descripciones detalladas, que pudieran ir más allá, en un iter urbano como el recién evocado, de la ciudad del título: Amor y odio de un gitano en Guernica.

Guernica, además, entra en el relato como antecedente, importante pero que permanece como tal, resolviendo el destino de la ciudad herida en pocas frases y enderezando una historia de amor minada por el racismo, en un contexto que acaba por escapar a la propia Guerra de España. Un gitano se encuentra por casualidad en esa ciudad el 26 de abril de 1937. O sea, en el lugar equivocado y en el momento equivocado, aunque «Guernica, aquel día, no parecía realmente un lugar equivocado", con "jóvenes tumbados en los prados tomando el sol y charlando» y «soldados tranquilos»: «Quién habría imaginado nunca que, de ahí a poco, la tierra se habría levantado tanto como para alcanzar el cielo. El gitano escuchó el ruido de los aviones, alzó los ojos y vio el cielo oscurecido por los aparatos [...] Aquel día en Guernica se experimentaba por primera vez en la historia el bombardeo aéreo de una ciudad». El resultado, tristemente conocido, es luego resumido en una glosa, discutible, que deja entrever el análogo destino de otras ciudades espańolas y europeas en los oscuros años que vendrían: «De la ciudad quedó bien poco en pie. Ciudadanos y soldados vagaban por entre los escombros arrebatados por el estupor de la novedad. En la guerra siempre es así, el horror golpea e indigna la primera vez, luego se convierte en rutina». El punto de vista del gitano, que tiende a ocuparse de sus asuntos incluso cuando el bombardeo ha empezado, se pierde entonces, junto a sus seres queridos, caídos todos ese día, con el avance de la guerra civil, durante la cual, combatiendo para los republicanos, conoce a una bellísima vasca. Estalla el amor, termina la guerra, y el gitano planea una fuga para dos cuando estamos ya, por lo menos, en junio de 1940, puesto que en el relato se lee: «italianos y alemanes acababan de invadir Francia». Impaciente, el gitano espera a su novia en una estación española, pero la ve bajar del tren en compañía de un franquista. Sinténdose traicionado, la mata y huye a Sudamérica. Allí le alcanzan los hermanos de ella, por los cuales se entera de su inocencia, y pregunta: «¿Por qué moriré, hoy? 
¿Por haberla matado o porque quería huir conmigo?». Le responden con una pregunta que ataja cualquier esperanza: «¿Cuál es la diferencia?», y el gitano muere, deviniendo relato, en la posada: «la historia de un gitano que subió un día a un tren que iba a la parte equivocada, como toda su vida».

Hojearé aún más velozmente a Camilleri, cuyo brevísimo relato, de ambientación totalmente italiana, se centra en una confusión de identidades en que la guerra civil española desempeña un papel relativo. Pero es cierto que Andrea Camilleri nació en 1925 y hasta se puede permitir en su trabajo un comienzo "testimonial» en el cual deslizar un arranque narrativo clásico: «En el tiempo de la Guerra de España, tenía yo unos diez años; a lo largo de mi pueblo, Porto Empedocle, pasaban a menudo buques mercantes soviéticos cargados de víveres y medicinas [...]. Cada tanto caían en puestos de bloqueo de la Marina militar italiana y eran sometidas a prolijos registros para ver si había armas amontonadas en las bodegas. Una noche se desencadenó un temporal de mal augurio $[\ldots] »$.

Pasemos, pues, a Bruno Arpaia y El ángel de la historia, diciendo en seguida que la parte de la novela que más nos interesa coincide, poco más o menos, con su primera mitad, con esas primeras 140 páginas al final de las cuales asistimos a un ligero, tenue pero significativo cambio de consigna, en el que vale la pena detenerse por la particular estructura de la novela, de la que ya hemos hablado. Por un lado, efectivamente, tenemos las ciudades españolas heridas hasta inicios de la primavera de 1939; por otro, la capital francesa bombardeada, al amanecer del 3 de junio de 1940, por la Luftwaffe. París, altísima síntesis urbana de «otros mil fines del mundo, en el curso de milenios», ${ }^{123}$ según un libro extraño, que hay que usar «con mucha cautela» pero, por momentos, «sugestivo y estimulante»: ${ }^{124}$ El retorno de los brujos (1960), de Louis Pauwels y Jacques Bergier, ensayo novelado, fantahistórico, que reúne apocalípticamente muchas ciudades heri-

123 Louis Pauwels y Jacques Bergier, Le Matin des magiciens. Introduction au réalisme fantastique, Gallimard, París, 1960 y col. Folio, 1972, pp. 241-242 (El retorno de los brujos, trad. J. Ferrer, Plaza y Janés, Barcelona, 1980).

124 Juicio de Furio Jesi, Cultura di destra, cit., p. 53. 
das, diversos incendios, y muchos datos sin indicar su fuente; en el caso concreto de París, continúa evocando el incendio de Berlín. ${ }^{125}$

Por lo demás, es verdad también que un amante un tanto singular de la capital francesa, Adolf Hitler, ${ }^{126}$ piensa en una París destruida por el fuego y acaso se hace profeta de la destrucción de Berlín, percibiendo casi en una dionisíaca anulación estética esas dos realidades urbanas donde estrategias y leyendas oscuras han terminado por entrecruzarse y dar resultados novelescos más o menos buenos: desde el francés ¿Arde Paris?, de 1964, de Dominique Lapierre y Larry Collins, hasta el italiano El incendio de Berlin, de 1995, de Helga Schneider. ${ }^{127}$

125 Que es solo el punto final, podríamos decir, de todas las ciudades alemanas devastadas por ataques terrestres y aéreos, de los que se empieza a hablar con mayor fervor en Alemania y en el resto del mundo para denunciar, en diversos niveles de investigación (ensayístico, histórico y literario), una realidad frecuentemente acallada por los vencedores - y por los vencidos - del segundo conflicto mundial: me refiero, para las muchas ciudades heridas por bombardeos, al reciente libro de Jörg Friedrich, Der Brand, de 2003 ( $L a$ Germania bombardata. La popolazione tedesca sotto gli attacchi alleati 1940-1945, cit.), y, para la relación entre bombardeos, guerra aérea y literatura, a las conferencias ofrecidas en Zúrich en 1997 por W. G. Sebald y recogidas en el volumen Luftkrieg und Literatur, Carl Hanser Verlag, Múnich/Viena, 1997, recientemente traducido con títulos discutibles, si bien indicativos de la orientación del trabajo, en francés, De la destruction comme élément de l'histoire naturelle, Actes Sud, Arles, 2004, y en italiano, Storia naturale della distruzione, Adelphi, Milán, 2004 (Sobre la historia natural de la destrucción, trad. Miguel Sáenz, Anagrama, Barcelona, 2005). Entusiastas muchas de las recensiones italianas (de Trevi a De Luna). Más interesantes, en mi opinión, los comentarios de Gustavo Corni, «Buchi della memoria", L'Indice, 1, 2005, p. 5.

126 Cfr. Arno Breker, «Hitler: Paris à la sauvette», Historia, 319, 1973, pp. 106-117. Cfr., del otro lado de la barricada, la reconstrucción de Irène Némirovsky, «Tempête en juin", en Suite française (1941-1942), pról. Myriam Anissimov, Denoël, París, 2004, y col. Folio de Gallimard, París, 2006, pp. 31-303 (también las pp. 519-537). Ha saludado la edición italiana de Suite francese, Adelphi, Milán, 2005, y «el relato cinematográfico de la fuga de los franceses de París, en junio de 1940, con la llegada de los alemanes» en Temporale di giugno, Gabriella Bosco, "Guarda la Francia che perde l'onore», ttL TuttoLibri, 1488, 2005, p. 3 (Suite francesa, trad. José Antonio Soriano, Salamandra, Barcelona, 2005).

127 Cfr. Dominique Lapierre, Larry Collins, Paris brûle-t-il? (25 août 1944). Histoire de la libération de Paris, Laffont, París, 1964 (:Arde Paris?, trad. Joaquín Rodríguez Castro, Plaza y Janés, Barcelona, 1976), y Helga Schneider, Il rogo di Berlino, Adelphi, Milán, 1995 (cfr. No hay cielo sobre Berlín, trad. Nieves López Burell, Salamandra, Barcelona, 2005), donde hay páginas de altura sobre la toma de la ciudad por parte de los rusos que a veces recuerdan a la anónima Una donna a Berlino. Diario aprile-giugno 1945 (1954 y 1959), Mondadori, Milán, 1957 y Einaudi, Turín, 2004, introd. Hans Magnus Enzensberger, pp. V-IX, escrita a posta para la nueva edición italiana, que sigue la $1 .^{a}$ ed. alemana de 1959. 
En la novela de Arpaia, sin embargo, se habla de otro amante de París, Walter Benjamin, que «no tuvo tiempo de coger la máscara antigás y bajar a la calle, porque el bombardeo terminó pronto, dejando en el aire un olor a carne quemada, a cascotes y pólvora que le llegaba a ráfagas por la ventana abierta, mezclado con las sirenas de las ambulancias y los bomberos». ${ }^{128}$ Es casi un "punto limite» de la novela, del que, para nuestros fines, habría que partir para leerla hacia atrás y captar «el rigor mortis de la guerra» del que Koestler logra huir «sin dejar rastro»" ${ }^{129}$ pero del que Benjamin apenas consigue alejarse, «inmóvil» como la ciudad herida, que no puede sino esperar al próximo bombardeo, con «la voz de un profeta, calma [...] del que se confía a la catástrofe para recomponer el mundo "en un abrir y cerrar de ojos" ", quieto, sentado tras ese «escritorio» de la Bibliothèque Nationale que se convierte en su «Línea Maginot». ${ }^{130}$

Entre el testamento, firmado, de las tesis Sobre la filosofía de la historia y los infinitos, casi anónimos Pasajes, gran libro de citas en que «cada frase estaba escrita como si fuese la primera en asomarse al mundo, o la última antes de la catástrofe», ${ }^{131}$ Walter Benjamin y su obra, indisolublemente ligados, se reflejan juntos en el mundo de las ciudades heridas, del que pasan a ser una suerte de doble: «El libro se presentaría como un campo de escombros a los ojos de un superviviente que, herido, se despertase al día siguiente de una batalla». ${ }^{132}$

Sobre los rusos en Berlín, cfr. nuevamente Erich Kuby, Die Russen in Berlin 1945, Scherz Verlag, Múnich-Viena, 1965 (trad. italiana en Einaudi, Turín, 1966 [y española, Los rusos en Berlín, en Caralt, Barcelona, 1966]), y el más reciente Antony Beevor, Berlino 1945 (2002), Rizzoli, Milán, 2003 (Berlin: la caída, 1945, trad. David León, Crítica, Barcelona, 2003), autor que, explorando archivos rusos y alemanes, llega igualmente, un cuarto de siglo después de The Spanish Civil War de 1982, a la reescritura de la Guerra de España con La guerra civile spagnola (2006), Rizzoli, Milán, 2006 (La guerra civil española, trad. Gonzalo Pontón, Crítica, Barcelona, 2005).

128 Arpaia, L'angelo della storia, cit., p. 148.

129 Ib., p. 145.

130 Ib., pp. 138 y 136.

131 Ib., p. 78. Cfr. a este propósito Susan Sontag, «Sotto il segno di Saturno» (1978), en Sotto il segno di Saturno, Einaudi, Turín, 1982, pp. 106-108 (Bajo el signo de Saturno, trad. Juan Utrilla, Edhasa, Barcelona, 1987; para Benjamin, v. Discursos interrumpidos, I. Filosofía del arte y de la historia, trad. Jesús Aguirre, Taurus, Madrid, 1992, y Libro de los pasajes, trad. Fernando Guerrero et al., Akal, Barcelona, 2005).

132 Arpaia, L'angelo della storia, cit., p. 78. 
No bien transcurridas setenta páginas (las acabamos de recorrer al contrario), donde el destino de Benjamin y el de París se unen cada vez más, entre 1939 y 1940, emerge un registro bien distinto en la narración de Arpaia, confiado al combatiente republicano Laureano Mahojo, que hace el amor incluso entre los bombardeos de Barcelona, si bien encuentra algún inconveniente de naturaleza "técnica» debido al evidente estrés de copular bajo las bombas. Motivo que también está en Guernica de Lucarelli y que, en el contexto de una ciudad herida, ofrece una variante del binomio «amor y muerte». Seguimos así, desde el principio de la novela, en un clima tragicómico pero sustancialmente serio, los destinos urbanos de Gijón, la ciudad de Laureano, que "parecía un anillo del infierno, iluminada como si fuera de día por los incendios»; ${ }^{133}$ Bilbao, por cuyo cielo, de repente, «venían cincuenta cazas, setenta trimotores, a martillearnos con las ametralladoras y las bombas"; ${ }^{134}$ la citada Barcelona, donde, terminado el bombardeo, se sale del refugio, se bromea y se ríe con las chicas, pero constatando que "había poco de que reír, ahí afuera»: "No se contaban, los muertos y los heridos. Por todas partes humo y polvo, y las sirenas de las ambulancias que iban y venían. Edificios enteros se habían desmenuzado como si fueran de turrón, en las calles se abrían precipicios y el agua que brotaba de las tuberías envolvía en lentos remolinos los cuerpos de los pobres desgraciados que habían quedado atrapados». ${ }^{135}$ Poco después, la misma Barcelona es presentada como una «ciudad atontada por los bombardeos", gracias al ensañamiento de los italianos que "partían de la base aérea de Mallorca y descargaban todas las bombas que podían». ${ }^{136}$ Entre otras cosas, son propiamente los latinos los responsables del coito interrumpido al que aludíamos, que da paso a algunos momentos de esta nueva guerra moderna y tecnológica, como sucede, en parte, en el relato de Carlotto con los bombardeos en alfombra, continuos: «Llegaban en oleadas los bombarderos, más o menos cada tres horas, golpeando cada barrio, cada objetivo civil y militar. Nunca se había visto nada igual. Era la primera vez en la historia, y yo me hallaba en medio». ${ }^{137}$ Estamos cerca, en suma, de la caída de Barcelona, el 26 de enero de 1939, ciudad evoca-

133 Ib., pp. 10 y 16.

134 Ib., p. 11.

135 Ib., p. 24.

136 Ib., p. 35.

137 Ib., p. 36. 
da ya casi solo en relación con los «bombardeos, cada vez más fuertes y espantosos». ${ }^{138}$ Nos parece estar escuchando —aunque su intención fuera otra- un documental de Giorgio Ferroni, „España, una grande libre! (1939): "La aviación legionaria, anticipando la marcha liberadora de las tropas, domina ya los cielos de Cataluña. Las águilas de acero sobrevuelan ya la ciudad que aguarda [...] últimos días de la Barcelona roja». Y, en efecto, la «Barcelona caída en manos de los franquistas» interviene en el desarrollo de la novela de Bruno Arpaia ${ }^{139}$ pero alojada ya, por ese cambio de consigna del que hemos hablado, en la narración dedicada a Walter Benjamin y París. No obstante, punto de encuentro y rendez-vous último de dos distintos destinos existenciales no es una gran ciudad herida sino un microcosmos, un pueblo: Port Bou. También él, de todas maneras, herido, con los «escombros de la guerra todavía a la vista». ${ }^{140}$

Cuando la novela de Arpaia aparece en Francia, con el título reconvertido en Dernière frontière, Lionel Richard, al reseñarlo en un apéndice al dossier de Magazine Littéraire de abril de 2002, dedicado a Walter Benjamin, comenta: «una novela que no es más que un cascarón cargado de artificio, con un bricolaje convencional». ${ }^{141}$ Algo hay de verdad en este juicio, aun cuando sea harto severo y parcial, sustancialmente basado en la parte benjaminiana de la novela.

Lo mejor del texto de Arpaia — con los límites ya vistos— es la parte dedicada a Laureano, cuyas gestas, heroicas y eróticas, son desarrolladas paralelamente al destino de Benjamin y de Europa, casi en una suerte de contrapunto cómico-serio al tragicismo de los años treinta y de 1940. En El ángel de la historia se juega demasiado, como ya sugeríamos, con la bipolaridad «combatiente-cuerpo»/«intelectual-cabeza». Hacia el final, ${ }^{142}$ Benjamin insiste en entregar su testamento, las aludidas tesis Sobre la filosofía de la historia, texto de extrema densidad especulativa e incisivo laconismo, a un

138 Ib., p. 68.

139 Ib., p. 75. Cfr. el DVD Spagna 1936-1939, Istituto Luce, Roma, 2004.

140 Ib., p. 177. Y para Port Bou cfr. de nuevo ese antecedente italiano, poco conocido, sobre el que reclamábamos la atención al final del segundo capítulo: Vittorio Bodini, «La lobbia di Masoliver (1968-1969)», en La lobbia di Masoliver, cit., p. 94.

141 Cfr. Magazine Littéraire, 408, 2002, p. 59.

142 Arpaia, L'angelo della storia, cit., p. 249. 
hombre que «no entendía por qué esos folios de escritura apretada fuesen más importantes que él [Walter Benjamin] y su vida»; a un hombre que en 1940, a un ańo del final de la guerra civil, hace contrabando por amor y se despierta, una de esas mañanas en que se cruza con el filósofo, con pensamientos de esta traza: «Las mujeres, ya se sabe, aunque no lo digan, no hay ni una a la que no le guste que la repasen por la mañana temprano, envueltas en ese olor a dormido, abobadas todavía por el sueńo, casi maravilladas». ${ }^{143} \mathrm{Y}$ es realmente el continuo contraste, casi didascálico, el que impide el retrato paralelo del intelectual alemán dentro de las habituales coordenadas: un «ratón de biblioteca» cuya resistencia, hecha de lectura y escritura, es absolutizada hasta tal punto, incluso a nivel moral, que resulta trivial; un hombre inepto, solitario, cerrado, que, sin embargo, al final se abre con el primero que llega, reconociendo casi a un álter ego (verdaderamente otro, que quede claro). Quien se emancipa, luego, no es siquiera el soldado-contrabandista, que "octogenario» cuenta toda su vida y cuanto sabe del filósofo y crítico alemán, y que termina por encarnar un lugar común: la resistencia de una vida basada en pensamientos bien distintos, como los citados más arriba. En definitiva, un poco de sexo, en guerra, te salva de las bombas, de Franco y hasta, en otra guerra, de los nazis y del gobierno de Vichy.

Claro que Arpaia, al enfrentarse con Benjamin, busca un auténtico ritmo histórico, histórico-biográfico, que comporta también fragmentos narrativos realistas y frases felices, acertadas, como las que juegan con Rojo y negro de Stendhal: «En la rue de l'Odéon, la librería estaba cerrada; Adrienne todavía no había llegado [...]. Adrienne abrió las persianas [...]. "Me marcho, lo he decidido", confesó Benjamin [...] "¿está completamente seguro de marcharse? París es tan grande, el lugar ideal para esconderse" [habla Adrienne Monnier, pero parece Benjamin, que en cambio dice con inédita concreción:] "[...] usted no conoce a los alemanes como yo" [...] sus manos se agitaban alrededor de un libro de Stendhal [...] "Entonces", se resolvió a decir, "ya que estamos, ¿̨le puedo pedir que me regale también Rojo y negro? Querría volver a leerlo, pero mi ejemplar hace años que está perdido por Europa...”. Veinticuatro horas después, los alemanes atravesaban el Sena [...]». ${ }^{144}$

143 Ib., p. 205.

144 Ib., extractos de pp. 159-161. Para Adrienne Monnier y Sylvia Beach, cfr. el reciente y rico estudio de Laure Murat, Passage de l'Odéon. Sylvia Beach, Adrienne Monnier et la vie littéraire à Paris dans l'entre-deux-guerres, Fayard, París, 2003. Cfr. Nicola Bertasi, "Alla ricerca del libro perduto», Alias, 21, 2005, p. 5. 
Así han ido las cosas con la historia; también con la vida. Arpaia la traduce en literatura pero mantiene a raya la contaminación fetichista, difuminándola, y conjura los excesos de la novela "posmoderna» Tutto il ferro della Torre Eiffel, de Michele Mari, publicada por Einaudi en 2002. Ambiciosa, divertida, pero totalmente replegada en una divagación literaria, como algún recensor ha sugerido. ${ }^{145}$

Habíamos aludido antes, con Arpaia, a Mallorca y los bombarderos italianos que desde la base aérea de la isla despegan con su carga de muerte hacia ciudades espańolas en manos de los rojos. Muchas son las imágenes que vuelven sobre esta realidad en la larga novela de Fabrizia Ramondino, Guerra de infancia y de España, de ambientación mallorquina, precisamente, y que recupera las primeras Historias de patio (1983): La señora de Son Batle, Los criados, Los pájaros de Narcís, El noviazgo, ${ }^{146}$ ofreciéndoselas al lector, ligeramente modificadas, en la primera parte.

En cuanto a imágenes relativas a la realidad de la guerra y los bombardeos, se presenta casi un problema de elección, pues «La isla encantada», como reza el segundo capítulo de la primera parte de la novela, alberga el imaginario infantil de la pequeña protagonista, pero también, enseguida, la guerra: «Por las varillas de las persianas se filtraba el sol, y oleadas de perfume de los almendros en flor envolvían la isla, pero en el cielo se oía el zumbido de los aviones que se elevaban para bombardear

145 Cfr. Alessandro Barbero, «La letteratura come feticcio. Benjamin e il nano malefico", L'Indice, 1, 2003, p. 8 (Todo el hierro de la torre Eiffel, trad. María Jesús Fenero, Seix Barral, Barcelona, 2005). Sobre el uso que de algunos grandes críticos e intelectuales del siglo XX, entre ellos Walter Benjamin (1892-1940), precisamente, Giacomo Debenedetti (1901-1967) y Roberto Bazlen (1902-1965), ha hecho la narrativa de los últimos veinte años, desde Del Giudice hasta Arpaia y Mari, pasando por Antonio Debenedetti, di una lección en Florencia el 12 de noviembre de 2003, titulada "Un angelo, un dandy e "un uomo a cui piaceva vivere negli interstizi della cultura e della storia" ". Más recientemente, he tratado de relanzar y profundizar el tema en "Il fascino della differenza nell'identità (in crisi) dello scrittore, del critico, dell'intellettuale. Bazlen, Debenedetti, Benjamin nella narrativa italiana: 1983-(2001)-2004», en Alain Sarrabayrouse y Christophe Mileschi (eds.), Images et formes de la différence dans la littérature narrative italienne des années 70 à nos jours, actas del congreso de Grenoble, 24-25 de noviembre de 2005, Cahiers d'Études Italiennes. Novecento... e dintorni, 7, 2008, pp. 159-170.

146 Cfr. Ramondino, Storie di patio, cit., pp. 3-92. 
castillos o cuarteles». ${ }^{147} \mathrm{La}$ adversativa es incisiva, pero no apunta a las ciudades heridas. De hecho, Ramondino raramente seguirá el vuelo de los aviones hasta su llameante meta urbana. El punto de vista que les persigue les pierde antes, acaso en un campo de la isla, como sucede en El pájaro de la guerra. ${ }^{148}$ Por lo demás, ni siquiera las "Noticias de la guerra» — capítulo de la parte IV - están dispuestas a completar el cuadro en tal sentido; tampoco las situadas en apéndice, ya citadas. ${ }^{149}$

Lo que más interesa a Fabrizia Ramondino es enunciar la contaminación del Edén, del parque de infancia. ${ }^{150}$ Desde esta perspectiva — con tonos fuertes y crudos que la aproximan, en parte, a otra voz partenopea, Elena Ferrante-,${ }^{151}$ un dedo clavado en el culo de la niña por un amante de la gobernanta, "un clavo de carne»—que se traduce en la palabra "tortura» y luego en «tormentos», como los de las «vírgenes mártires cristianas y las monjas de Barcelona»—, ${ }^{152}$ equivaldría a una bomba, un bombardeo; y un episodio semejante anticipa incluso la Historia del niño de Guernica: la violencia, la tortura, el tormento que el nin ha debido de sufrir, en la realidad histórica y no fuera de ella, y por tanto también en las ciudades heridas de la guerra (y no en la isla de Nunca Jamás).

147 Cfr. Ramondino, Guerra di infanzia e di Spagna, cit., p. 23. Cfr. Maryline Maigron, "Conflits armés et conflit intérieur dans Guerra di infanzia e di Spagna de Fabrizia Ramondino", en Alain Sarrabayrouse (ed.), Images littéraires de la société contemporaine, actas del congreso de Grenoble, 21-22 de noviembre de 2003, Cahiers d'Études Italiennes. Novecento... e dintorni, 3, 2005, pp. 155-165.

148 Cfr. Ramondino, Guerra di infanzia e di Spagna, cit., pp. 227-229; también, por ejemplo, p. 197.

149 Ib., pp. 365-368 y 415-417.

150 Sobre la infancia y la guerra civil española véanse, desde esta perspectiva, pero sin la mediación de la isla encantada, algunas páginas de François-Marie Ribadeau, Le Pain et la Pierre, Atelier Marcel Jullian, s. 1., 1979, pp. 67-75, correspondientes al cap. IV, «Guerre civile dans le village». Cfr. al menos, para diversas consideraciones generales, todas importantes, Donald W. Winnicott, "Les enfants et la guerre» (1940) en Les Enfants et la guerre (1984), Payot et Rivages, París, 1994 y col. Petite Bibliothèque Payot, 2004, pp. 39-48; Anna Bravo, Anna Maria Bruzzone, «Bambine» en In guerra senza armi, cit., pp. 83-106; Madeleine Frédéric, "La guerre 14-18 dans les romans belges de l'entre-deux-guerres», en "La guerre, notre matrice», Jibrile, 5, 2005, pp. 54-61, que analiza también un texto recientemente reeditado: Georges Linze, Les Enfants bombardés, Renaissance du Livre, Bruselas, 1936 y Labor, Bruselas, 2002.

151 Pienso aquí, sobre todo, en L'amore molesto (1992).

152 Cfr. Ramondino, Guerra di infanzia e di Spagna, cit., p. 63. 
No es casual, entre otras cosas, que en Historia del niño de Guernica haya un precedente de naturaleza sexual, con un joven quinceañero que se meterá fraile porque, enamorado de una hermosa vecina de casa, buscará sus favores pero encontrará solo un «seno desnudo [...] todo llagado, devorado por el cáncer», lo que será interpretado, a medias entre lo sacro y lo profano, como una suerte de revelación de «Nuestra Seńora de la Teta». ${ }^{153}$ En suma, el cuerpo o el alma del hombre es el auténtico lugar, físico, de la herida. Tanto que, sobre la ciudad destruida por el bombardeo el 26 de abril de 1937, la autora propone el seco relato del fraile ya envejecido, pero buscando, significativamente, un vínculo con lo que todos saben y viven de la guerra en Mallorca, incluidos los nińos.

En este sentido, quien escribe parece casi cerrar el relato con un imaginario infantil y aislado. Relato que luego, en cambio, se abre a una especie de apocalipsis tendente a evitar el lugar común de la nueva guerra moderna y tecnológica, no obstante el familiar arranque que la introduce: «Y, de repente, jaquello fue el inferno! El cielo retumbó. Aquel ruido me heló la sangre; bien conocía ese ruido. Todos lo conocen en Mallorca. Pero no eran uno o dos aviones, ni siquiera una escuadrilla de cinco. Eran centenares, oscurecían el cielo; brillaban, escupían fuego y llamas. No sabía si huir o echarme a tierra, o bien acurrucarme cubriéndome la cara con las manos. "Pero no —me dije—, ¡quiero verle la cara a Dios!". Y seguí de pie con los ojos en el cielo». ${ }^{154} \mathrm{Y}$ ese Dios — que a la postre, si se quiere, es el diablo de Lucarelli y del género literario que frecuenta - deja a Guernica en este estado: «La ciudad era un amasijo de ruinas, sangre, lamentos; propiamente como el seno que me había enseñado mi mujer. Toda podredumbre y llagas». ${ }^{155}$ He aquí el punto de referencia de Fabrizia Ramondino, que por lo demás se intuía mucho antes, como dijimos.

La traducción simbólica que la escritora napolitana pone en boca de ese fraile saltimbanqui, personaje marginal al modo de Soler, tiene el sabor amargo de una sentencia y es estructuralmente irreprochable. La ciudad herida es realmente, en estas páginas, el cuerpo del hombre herido, torturado por el mal de la existencia, de la historia. No hay mediaciones o abs-

153 Ib., pp. 202 y 203.

154 Ib., pp. 206-207.

155 Ib., p. 207. 
tracciones intelectuales, y las religiosas y metafísicas abonan, con un poco de ironía, la parábola dramática del hecho histórico, amplificándola desde un universo infantil que no solo no es inmune a ella, sino que se convierte, a su pesar, en su protagonista. La evocación de los escombros de Guernica lleva precisamente al reencuentro del nin, que parece haber sido torturado por el bombardeo: "durante tres días di vueltas por entre los escombros, socorriendo a heridos y moribundos. Encontré al nin en una placita, bajo un árbol arrancado. Parecía dormir y, sin embargo, estaba en coma, gravemente herido; como burlándose de él, una bala se le había alojado en el hueco del brazo...». Después de los cuidados proporcionados en un convento, situado significativamente "fuera de la ciudad», el niño se cura pero no habla: «No habla, ¿sabéis?, no tanto por el miedo que ha cogido, sino por el horror que se vería obligado a contar al mundo». ${ }^{156}$

156 Ib. 


\section{NOTA FINAL}

El volumen que tienes, lector, entre las manos está formado por un tríptico un tanto anómalo, al menos a nivel cronológico. Este epílogo se propone ofrecer alguna explicación suplementaria, ya sea en relación con la estructura del libro, su progresiva elaboración, ya sea en relación con su forma, las modalidades discursivas a las que recurre y que en parte cambian de capítulo en capítulo con la cambiante recepción de la guerra civil española en la narrativa italiana; y acaso en la immediata proximidad del género, por ejemplo, la apertura y agregación de cuentos y novelas a libros de memorias, reportajes, diarios, ensayos, estudios, que inicialmente, en los ańos de la guerra, parecen traducir todo el compromiso antifascista - o compadecerse con la propaganda del régimen - obstaculizando esa versión novelesca del engagement que, en cambio, descuella en otras tradiciones como la francesa y la angloamericana.

Se advertirá un salto cronológico entre el primer capítulo, dedicado a El antimonio, cuento largo sciasciano aparecido en la segunda edición de Los tíos de Sicilia (1960), y el segundo, que vuelve repetidas veces a los tiempos de la guerra y retoma pero de otro modo la argumentación sobre Sciascia, tratando de acoger las mencionadas tradiciones, su influencia y las conexiones de un imaginario complejo entre los ańos treinta y sesenta.

Tras haber dado la palabra a la propaganda del régimen, con narraciones, teatro y cine (Sighinolfi, Rivalta, Genina), hemos tratado, con tríadas narrativas más o menos ejemplares y ligadas a una «teoría de las generaciones», de desplazarnos de los ańos treinta a los años cuarenta y cincuenta, saltando en fin a la muerte de Franco (1975), con el inicio de la llamada Transición; esa «transición» que tal vez «libera» a España y hace 
que se olvide un poco la guerra civil, al menos en Italia - la Italia de los «años de plomo»— y en el plano novelesco (pero incluso en la "península pentagonal» hay que esperar a las dos décadas siguientes, según la atenta estudiosa Maryse Bertrand de Muñoz).

Dicho esto, el segundo capítulo se propone llegar a un periodo a veces llamado, por comodidad, "posantimonio», que coincide con los ańos sesenta, setenta y ochenta (sobre todo, su primera mitad). Rápido excurso que, a decir verdad, no es muy significativo a efectos textuales - aunque tal vez existan en ese arco temporal otras experiencias narrativas italianas, importantes incluso, que ahora se me escapan-y precisamente por eso, casi par ricochet, lo confío a extensas citas — contenidas, en cambio, allí donde las correspondencias son múltiples, tal vez más concisas, diseminadas y más fácilmente traducibles en nota y acaso con el solo apoyo del número de página.

La complicidad con el lector, en suma, se articula en presencia de textos abordables con cierta facilidad dentro de la recepción de la guerra civil española en la narrativa italiana, remitiendo también, en última instancia, a un posible proyecto de antología, al que nos referiremos más adelante. Al mismo tiempo, el deseo de ancorarme en pocos pasajes seleccionados, citados por entero - $y$, tantas veces, fragmentariamente-, responde a una estrategia de conjunto y a un viejo sueño: fundir el libro de citas, de benjaminiano recuerdo y sobre el que he tenido oportunidad de reflexionar, con la microlectura bachelardiana y richardiana, ${ }^{1}$ acusada de ser una forma impresionista y subjetiva de crítica. He tratado desde el principio de sostener y corregir esta práctica, gracias a la ayuda $-\mathrm{y}$ a la «transversalidad»— de un amplio contexto, hecho de historia, filosofía, crítica social y compromiso político, pero también de indicios filológicos, búsqueda de fuentes, tramas intertextuales. Todo ello dentro de una aproximación comparatista e interdisciplinar. En ese sentido me he referido al cine, incluso al cine popular, hasta el punto de «reinjertar» las amargas intuiciones de cierta comedia a la italiana, aun subrayando sus fáciles (burlescas) y a veces involuntarias complicidades con el objeto de su propia sátira: el fascismo y sus guerras.

1 Permítanme remitir a Curreri, “Démolitions” e ferrovie. Su alcune deprecazioni del moderno tra Francia e Italia nella poesia del secondo Ottocento", Franco-Italica, 5, 1994, pp. 71-115; "Les images avant les idées», Franco-Italica, 13, 1998, pp. 177-218. 
Si el periodo "posantimonio» de los años sesenta, setenta y ochenta no ofrece muchos apoyos al discurso crítico, parece este despegar con cierta facilidad cuando se buscan sus intersecciones con el presente; un presente más desenvuelto y por momentos estereotipado, que podemos hacer partir de los años noventa y extender hasta nuestros días.

Propuestas incluso en clave provocadora, tales intersecciones sirven sobre todo para introducir el tercer y último capítulo, dedicado al presente, ligándolo mayormente a los dos primeros (una primera versión del tercero, reducida — aquí ampliada y completamente revisada — había aparecido ya en los Cahiers d'Etudes Italiennes. Novecento... e dintorni, 1, 2004, pp. 175-202, número dedicado a Dire la guerra?). Ello explica también alguna posible repetición, por lo que me excuso.

¿Por qué, entonces, partir con El antimonio? ¿Por qué no proceder, en cambio, à rebours y hacer del relato sciasciano la etapa intermedia y central de una argumentación más ordenada, concebida como un back to the source?

La preferencia concedida a El antimonio no se explica solamente por el relato en sí, siendo una obra maestra y, en mi humilde opinión, la mejor manifestación de la narrativa italiana sobre la guerra civil española, con pasajes que deberían ser antologados y hasta «canonizados»; tampoco se explica únicamente por el atento y prolongado interés de Sciascia en el conflicto, antes y después de ese relato, como también tratan de mostrar partes del segundo capítulo, en tal sentido ligado al primero y dependiente de él; dependiente, sobre todo, de su marcado papel de introducción y ensayo-guía, que se esfuerza por hacer dialogar la microlectura con un contexto histórico y literario nutrido de escritores que volverán en el desarrollo del discorso, cuales Vittorini y Brancati, y por abordar El antimonio en su integridad explícita e implícita, como cuento y como potencial novela, y dentro del conjunto de Los tíos de Sicilia, especialmente a partir de La muerte de Stalin.

El hecho es que, en El antimonio, la Guerra de España se convierte, en el frio de la segunda posguerra, en un episodio caliente y esencial de la reflexión intelectual sobre las relaciones entre cultura y poder, entre imaginario e historia, ofreciendo casi una síntesis entre pasado y futuro, desde 
los años treinta a los sesenta y más adelante, al menos hasta los ochenta, donde los últimos textos sciascianos, evocados desde el principio, ofrecen aún puntos de apoyo para un discurso de otro modo difícil de abordar, como decíamos más arriba.

Además, también los años noventa y los inmediatamente siguientes, al amanecer del nuevo milenio que estamos viviendo, repescan a menudo la guerra civil española como espejo de las contradicciones implícitas en las relaciones entre cultura y poder, imaginario e historia, reviviéndolas a veces casi con la misma intensidad, otras veces sirviéndose de ellas de manera más ligera. Tenemos a Antonio Tabucchi repensando a Sciascia (y a Pasolini) con mucha nostalgia, el Tabucchi de La gastritis de Platón (1997 y 1998), pero también el de Sostiene Pereira (1994), primero, y Tristano muere (2004), después, tan próximos en la recuperación "crítico-críptica» de la historia y de la Guerra de España a Claudio Magris en A ciegas (2005); pero están también Pino Cacucci, Fulvio Abbate, y Carlo Lucarelli, Bruno Arpaia.

Así, pues, empezar con Sciascia es un modo de anclar las mismas actualizaciones, sorprendidas entre el viejo y el nuevo siglo y milenio, en una argumentación que no quiere solo tratar de sondear en esa tradición narrativa italiana que, en relación con la guerra civil española, parece casi inexistente y, en el mejor de los casos, perdida, descuidada por lectores y estudiosos. Es más, hacer que la microlectura del llamado "pasaje de las mariposas» — del que procede el título del libro, traído de la frase «Dábamos vueltas alrededor de Madrid, como las mariposas, de noche, en torno a la llama» - reaccione con una serie de aproximaciones a El antimonio, a su ética del lenguaje, significa también moverse en seguida dentro del presente, de la recepción que hoy tenemos y podemos tener de Leonardo Sciascia y de algunas de sus imágenes, de sus ideas.

De ese modo, pasando del primero al segundo y tercer capítulos, tales aproximaciones nos permiten asimismo hacer algunas distinciones en el presente, a partir de un pasado próximo, el felix limes sciasciano de 1960, que es a su vez una summa del pasado tout court, el de los años de la Guerra de España y siguientes; años alimentados, por desgracia, por otras guerras, mundiales y civiles, que terminan por sobreponerse a aquella, sea cambiándole el nombre dentro de otros conflictos, sea perdiendo su especificidad e incluso perdiéndola completamente de vista. 
Pero la guerra civil española puede informar nuestro presente «desde lejos», y en tal sentido enseñarnos a decir el presente apenas transcurrido, la guerra de la ex Yugoslavia, por ejemplo con L'Autopsie Yougoslave (1999), de Rada Ivekovic; ${ }^{2}$ e incluso ese presente que ya es futuro, el de los centros de acogida, del que habla Tabucchi en Gli Zingari e il Rinascimento (1999).

Si no aislamos la literatura, como diríamos, «de biblioteca», expresada, encarnada en Sciascia, y antes en Vittorini, la guerra civil española todavía puede informar nuestro presente. Debemos solo reencontrar la literatura que todos hemos aprobado y dejado a un lado tal vez demasiado pronto, limitando y difuminando su impacto en una comunidad "posmoderna" formada por opinion makers más que por verdaderos escritores comprometidos, intelectuales.

Bien al contrario, deberíamos hacer de esa literatura la clave para entrar en el hoy; un hoy recorrido también, sin temor, mediante una práctica casi periodística, "de librería», "de quiosco» y "de Internet», que muda el tono del discurso pero no olvida las aproximaciones a una ética del lenguaje que El antimonio nos ha permitido evidenciar respecto al dato histórico de la guerra civil española.

De todos modos, hay obviamente un riesgo; o mejor, dos, muy ligados entre sí. El primero consiste en el hecho de que Sciascia podría revelarse, a fin de cuentas, demasiado pesado y poco funcional como unidad de medida. El segundo es que el hoy —en cuanto anclable a El antimonio y las tradiciones (italianas o no) que este relato compendia a nuestros ojos- podría aparecer más bien desligado y tal vez demasiado jugado sobre reseńas hipotéticas, selecciones y juicios tranchants.

Pero hay también dos ventajas, igualmente ligadas, conexas, y más o menos inmediatas: se dibuja un «mapa» para navegantes y se alcanza de algún modo a transbordar la más o menos implícita recepción narrativa de los años de la guerra (la tríada Vittorini, Delfini, De Céspedes), con la explícita pero no tan extendida de la segunda posguerra y décadas sucesi-

2 Cfr. Rada Ivekovic, Autopsia dei Balcani. Saggio di psico-politica (1999), Cortina, Milán, 1999, p. IX, que en su primer epígrafe cita, no por casualidad, a María Zambrano, El español y su tradición: «Deberíamos mirar a España y su drama desde lejos». 
vas (Jovine, Brancati, Pavese; Nitti, Parise, Dessí; y luego Lajolo, Bevilacqua y Joyce Lussu, Bodini; Chiusano) y, en fin, con la más difundida y en algunos casos más desenvuelta, si no directamente estereotipada, de un presente compuesto (Tabucchi, Cacucci, Lucarelli, Carlotto, Arpaia, Abbate, Casadei, Ramondino, Eco, Magris, Baravalle). En este esquema, por varias razones, explicadas en el texto o en nota, quedan al margen autores que no obstante son recordados una o más veces, caso de Linati, Puccini, Rèpaci, Montanelli, Bartolini, Amoroso, Del Buono, Camilleri, Alberti y Atzeni (o Evangelisti).

Las búsquedas e hipótesis interpretativas que están en la base de este libro se remontan a enero de 2003. Respondiendo a una invitación de Enzo Neppi y Christophe Mileschi y aprovechando un breve regreso a Italia, con la hospitalidad de mis padres y la amistad de Anna y Laura Dolfi y de Lidia De Federicis, empiezo rápidamente a recopilar materiales para participar en el seminario del GERCI (Groupe d'études et de recherches sur la culture italienne) de la Universidad Stendhal de Grenoble —-dedicado aquel año al tema de la guerra-, previsto para el 31 de enero. El título que elijo es la frase de El antimonio ya citada: «Dábamos vueltas alrededor de Madrid, como las mariposas, de noche, en torno a la llama», pero con un subtítulo: "Actualizaciones sobre la narrativa italiana y la guerra civil española (1996-2002)», que trata de aproximarse al día de hoy.

Mi lectura fulgurante de El antimonio data de diciembre de 2002. Hablo luego del relato con mi amigo Giuseppe Traina, profesor de la Universidad de Catania, quien me lo seńala como un texto un tanto descuidado por la crítica y, proporcionándome datos y materiales para darme ánimos, me invita a escribir un ensayo: Pippo tendrá la paciencia de leerlo y discutirlo, partiendo de la fecha de la segunda edición de Los tíos de Sicilia, Einaudi, 1960, y también de la más actualizada de su catálogo histórico, además de las reediciones que he tenido ocasión de consultar. En algunos libros y artículos recientes se lee la fecha de 1961, no corroborada sin embargo por datos concretos, mostrados claramente en el texto o en notas.

Por supuesto que titular con una cita sciasciana en Grenoble, Universidad Stendhal, era, antes que nada, un homenaje a Claude Ambroise, colega un tiempo de encendidas discusiones sobre Pasolini, Sciascia y tan- 
tas otras cosas. Pero ese título también era y lo es todavía, repito, un modo de anclar actualizaciones en una tradición narrativa italiana que en relación con la guerra civil española parecía descuidada por lectores y crítica, un poco como sucede con El antimonio.

En efecto, en los tres ańos transcurridos, aparte los elementos propuestos en el seminario, mi búsqueda se ha movido sobre todo en dos direcciones, tratando de colmar, por un lado, a partir principalmente de los estudios de Ambroise, el vacío de atención existente respecto a El antimonio, y, por otro, un vacío más general, de interés y de datos, respecto a la tradición, transformada luego en un plural interrogativo: «¿Tradiciones perdidas o inexistentes?».

Dos han sido las etapas significativas de esta promenade: un ágil librito ensayístico dedicado en buena medida al relato de Sciascia, sus fuentes y contexto, propuesto a la editorial Donzelli de Roma con la ayuda de mi amigo Francesco Benincasa, y un proyecto de antología para Einaudi, basado en relatos, de mayor o menor extensión pero autónomos, y en capítulos fácilmente extrapolables, y centrado en un primer momento solo en trabajos italianos, de Delfini, Jovine, Nitti, Sciascia, Lucarelli y Ramondino, después también de escritores extranjeros: Sartre, Corman, Hemingway, Regler, Sender, Nyssen, Chacón. Este proyecto, presentado gracias a los amigos Paolo Collo y Maria Teresa Polidoro, ha naufragado lamentablemente dos veces, en diciembre de 2003 y julio de 2005, y entre medias ha sido objeto de lectura en otras editoriales también del área turinesa, por mediación de Claudio Gallo, Milva Maria Cappellini y Enrico Badellino (Aragno, S. E. I., la antigua Testo e Immagine), y romanas (Donzelli y Quiritta, que por desgracia ha desaparecido, a pesar del éxito de su pequeño pero interesante catálogo de escritores italianos).

En definitiva, como en la mejor tradición, el seminario, el encuentro con amigos y colegas atentos, curiosos, ha sido el input de una investigación que luego se ha desarrollado sobremanera, yendo mucho más allá de aquella sede y de su ubicación editorial, la revista citada, a la cual he confiado un ensayo con el título cambiado y oscilante: Tra Madrid —símbolo, desde el inicio del conflicto y a todo lo largo de él, de toda la resistencia urbana herida en España (y en otras partes) - e Guernica, el «acontecimiento-símbolo» de Guernica, cuyo nombre — «más ardiente 
que las llamas de su incendio» (según Pierre Vilar en su presentación a Herbert R. Soutworth, La Destruction de Guernica. Journalisme, diplomatie propagande et histoire, citada, páginas XX-XI)— comparece más o menos significativamente en los cuentos y novelas de Lucarelli, Carlotto y Ramondino.

Además, como puede deducirse del último epígrafe del libro y de algunas notas, que contenidamente se abren a otras realidades urbanas (no solo españolas), Madrid y Guernica representan un desarrollo más general de la investigación, dedicado a las "Ciudades heridas en la narrativa italiana del siglo XX». Aun cuando la Guerra de España ha terminado por absorber casi todo mi tiempo. En ese sentido hay que leer mi participación en un importante congreso dedicado a ella en 2005 —donde he podido medirme con expertos de la talla de Jean Alsina, Bartolomé Bennassar, Maryse Bertrand de Muñoz, José Carlos Mainer y jóvenes como André Bénit, Robert Coale, François Godicheau, Mercedes Yusta- y también parte de mi contribución a una miscelánea de 2006 sobre los intelectuales entre los siglos XX y XXI, entre la crisis de las ideologías y la "pérdida de influencia de la intelligentsia en la calle». ${ }^{3}$

A propósito, remito a dos publicaciones mías: «Que peut la guerre d'Espagne dans le roman italien?», en Viviane Alary y Danielle Corrado (eds.), La Guerre d'Espagne en héritage: entre mémoire et oubli (de 1975 à nos jours), actas del congreso de Clermont-Ferrand, 10-12 de marzo de 2005, Presses Universitaires Blaise-Pascal, Clermont-Ferrand, 2007, pp. 259-270; «La sfida di non farsi leggere. Appunti intorno a Tristano muore (2004) di Tabucchi e Alla cieca (2005) di Magris», en Angela Barwig y Thomas Stauder (eds.), Intellettuali italiani del secondo Novecento, Verlag für Deutsch-Italienische Studien, Oldenbourg, 2007, pp. 176-195.

Deseo agradecer una vez más a todos los amigos del GERCI su afectuosa acogida en Grenoble, en cuya universidad he podido trabajar dos ańos como profesor adjunto - llegando a terminar y defender mi tesis doctoral-y empezado a pensar en este libro. Doy igualmente las gracias, al menos, a un par de amigos y colegas de la Universidad de Lieja, donde he desarrollado el trabajo: Jean-Pierre Bertrand y Benoît Denis, y a los

3 Cfr. de nuevo la síntesis de Christian Delporte, Intellectuels et Politique, cit. 
estudiantes de los cursos 2004-2005 y 2005-2006, que han seguido un seminario sobre la guerra civil española en dos fases: de Vittorini a Sciascia y de Sciascia a Tabucchi y Ramondino. Gracias de nuevo a Milva Maria Cappellini, Angelo Piero Cappello, Lidia De Federicis, Fabrizio Foni, Francesco Leoncini, Giuseppe Papponetti, Maria Teresa Polidoro, Giuseppe Pippo Traina y Antonio Zollino. Un agradecimiento especial va para Barbara Basso y Claudia Filipazzi, Paolo Collo y Gianfranco Maggi, por haberme invitado a la VII edición de Scrittoriincittàduemilasei en la ciudad de Cuneo (16-19 de noviembre), dedicada a algunos Pasajes del siglo XX y a la guerra civil española en particular.

Otra vez gracias, un gracias que los resume todos, a Anna Dolfi, que tuvo la gentileza de acoger este libro en la hermosa colección que dirige, Nuova Narrativa, de la editorial romana Bulzoni, en su primera edición en italiano. Y finalmente, a Malena Manrique y José Joaquín Blasco, Ignacio Martínez de Pisón y Antonio Pérez Lasheras, por haber propuesto, acogido y trabajado con paciencia la traducción de mi libro. 



\section{ÍNDICE ONOMÁSTICO*}

Abbate, Fulvio: 211, 211 n23, 234, 234 $\mathrm{n} 77,234 \mathrm{n} 78,235,235 \mathrm{n} 79,235$ $\mathrm{n} 82,236,264,266$

Adagio, Carmelo: 138 n105, 243 n 104

Adornato, Ferdinando: 213 n33

Agamben, Giorgio: 32 n78, 77, 77 n205, 78, 78 n210, 165, 165 n164

Alajmo, Roberto: 67

Alary, Viviane: 235 n83, 268

Alberti, Barbara: 198, 198 n252

Alberti, Rafael: 42 n111, 266

Aleggiani, Mariella: 224 n59

Alicata, Mario: 13 n10

Allen, Jim: 201

Alovisio, Silvio: 132 n88

Alsina, Jean: 268

Álvarez del Vayo, Julio: 114

Ambroise, Claude: 11, 11 n2, 13 n11, $23 \mathrm{n} 48,30,31,36 \mathrm{n} 96,38 \mathrm{n} 100,42$ n109, 49 n126, 51, 51 n134, 62, 62 n164, 63, 63 n165, 68, 68 n176, 73, 79 n216, 81 n223, 82, 83, 83 n226, $94 \mathrm{n} 257,95,97,98 \mathrm{n} 264,125,125$ n69, 148 n127, 156 n140, 266, 267

Amidei, Sergio: 144

Amoroso, Filiberto: 198, 198 n252, 266

Amoruso, Vito: 123 n65, 128 n78

Andreini, Alba: 157 n141

Anelli, Amedeo: 192 n238

Anfuso, Filippo: 219, 219 n46

Anissimov, Myriam: 252 n126
Arango, Doroteo: v. Villa

Arendt, Hannah: 14, 15 n17, 22 n46, $23,85,85 \mathrm{n} 233$

Armangué i Herrero, Joan: 246 n111

Aróstegui, Julio: 221 n51

Arpaia, Bruno: 196, 196 n247, 223 n56, 225, 225 n61, 225 n62, 228, 233, 234, $234 \mathrm{n} 79,245,245 \mathrm{n} 107,251$, 253, $253 \mathrm{n} 128,253 \mathrm{n} 132,254,255$, 255 n142, 256, 257, 257 n145, 264, 266

Arpino, Giovanni: 142 n115

Arrabal, Fernando: 234, 235 n79

Ascaso, Francisco: 234

Asor Rosa, Alberto: 170, 170 n177

Atzeni, Sergio: 76, 76 n202, 240, 266

Auden, Wystan Hugh: 123, 123 n65, 128 n78

Audino, Dino: $201 \mathrm{n} 4$

Augé, Marc: 73 n193, 75, 75 n198

Augieri, Carlo Alberto: 169 n176

Azaña, Manuel: 78, 78 n211, 89, 89 n246, 89 n247, 90, 90 n247, 100 n4, $141 \mathrm{n} 111,155 \mathrm{n} 139,156 \mathrm{n} 139,158$, 174, $174 \mathrm{n} 187$

Azcona, Rafael: 200

Bach, Johann Sebastian: 168

Bachelard, Gaston: 54 n141, 57, 57 n150

Badellino, Enrico: 267

\footnotetext{
* El nombre de Leonardo Sciascia, que atraviesa casi todo el libro, no aparece en este índice.
} 
Bajtin, Mijaíl: 175 n191

Bakunin, Mijaíl Alexandrovich: 76, 76 n202, 240

Baldi, Guido: 20 n38

Baldini, Eraldo: 200, 211 n23, 230 n69, 234 n77, 234 n78

Balletta, Felice: 38 n 100

Balzac, Honoré de: 212

Banks, Russell: 237 n87

Baravalle, Roberto: 219, 219 n49, 266

Barbera, Alberto: 132 n88

Barbero, Alessandro: 257 n145

Bargelesi, Alberto: 135 n95

Baricco, Alessandro: 125 n68, 232, 233, 233 n73, 236

Barth, Karl: 91, 92 n252

Bartolini, Elio: 118, 118 n50, 149, 150 n129, 266

Barwig, Angela: 116 n46, 208 n16, 239 n92, 268

Basso, Barbara: 269

Bastico, Ettore: 72

Bataille, Georges: 78

Bauman, Zygmunt: 38 n98

Bazlen, Roberto 'Bobi': 257 n145

Beach, Sylvia: 256 n 144

Beccaria, Cesare: 156

Bedeschi, Giuseppe: 120 n55

Beevor, Antony: 253 n127

Benadussi, Lorenzo: 154 n138

Benedetti, Arrigo: 168

Benedicto XIV: 138

Benincasa, Francesco: 267

Bénit, André: 131 n85, 268

Benjamin, Walter: 77, 196, 208 n16, 225, 253, $253 \mathrm{n} 131,254,255,256$, 257 n 145

Bennassar, Bartolomé: 100 n4, 135 n92, 245 n 108, 268

Berardinelli, Alfonso: 17, 17 n27, 29, 29 n69, 38 n98

Berdah, Jean-François: 108 n28, 146, 146 n123, 245 n 108

Bergier, Jacques: 251, 251 n123

Bergonzoli, Annibale: 97, 114, 193 n238

Bernanos, Georges: 42, 42 n111, 57, 140, 204, 204 n7, 209, 212, 246, 246 n112

Berneri, Camillo: 42, 145 n122, 246, 246 n 110
Bertasi, Nicola: 256 n144

Bertazzoli, Raffaella: 124 n67

Bertini, Mariolina: 12 n2, 13 n8

Bertone, Manuela: 12 n7, 19 n31

Bertoni, Barbara: 241 n98

Bertrand, Jean-Pierre: 268

Bertrand de Muñoz, Maryse: 130 n85, 240 n94, 262, 268

Bettini, Maurizio: 22 n46

Beyle, Henri: v. Stendhal

Bevilacqua, Alberto: 189, 189 n228, 189 n229, 189 n230, 191, 192 n236, 266

Bianchini, Angela: 243 n102, 243 n103, 243 n104, 245 n 107

Bidault, Georges: 14 n13

Bilenchi, Romano: 162 n150

Biocca, Dario: 120 n55

Blanchot, Maurice: 29, 30, 30 n71, 40

Blasetti, Alessandro: 174

Blair, Eric Arthur: v. Orwell

Bleiman, Mijaíl Y.: 107 n25

Blewitt, Phyllis: 122 n63

Blewitt, Trevor: 122 n63

Blum, León: 60

Bobbio, Norberto: 18 n29, 34, 34 n85, $94 \mathrm{n} 257$

Bocca, Giorgio: 192 n237, 193 n239

Bodini, Vittorio: 189, 195, 195 n246, 197, 197 n251, 198, 255 n140, 266

Boixareu, Mercè: 131 n85

Böll, Heinrich: 38 n100

Bongiorno, Arrigo: 188

Bongiovanni, Bruno: 16 n25

Bonhoeffer, Dietrich: 211 n23, 234, 235 n81

Bonini, Paola: 221 n54

Borges, Jorge Luis: 125, 125 n71

Borsellino, Nino: 211 n22

Borrell García, Federico: 116 n44

Bosco, san Juan: 138, 138 n104, 182

Bosco, Gabriella: 252 n126

Botti, Alfonso: 138 n105, 243 n104

Bourdet, Claude: 14 n13

Bourdieu, Pierre: 40, 40 n106, 41, 41 n108

Bouveresse, Jacques: 40 n106

Bovaia, Roberta: $244 \mathrm{n} 105$

Brancati, Vitaliano: $38 \mathrm{n} 100,82,85,86$, 86 n237, 143, 144 n119, 147, 150, 
152, 153 n136, 154, 154 n137, 155, 156, 156 n140, 170, 178, 183, 263

Braschi, Nicoletta: 202 n5

Brault, Pascale-Anne: 27 n61

Bravo, Anna: 217 n41, 258 n150

Brecht, Bertolt: 247

Breker, Arno: 252 n126

Bresolin, Alessandro: 23 n48

Broch, Hermann: 107, 108 n26

Brombert, Victor: 22 n44, 66, 66 n171

Bronstein, Lejva: v. Trotsky

Broué, Pierre: 109 n31, 109 n32

Bruzzone, Anna Maria: 217 n41, 258 n150

Burch, Noël: 140 n110

Busi, Aldo: 204 n5

Buzzati, Dino: 71, 71 n186

Cabiddu, Gianfranco: 76

Cacucci, Pino: 119 n54, 121, 189 n230, 199, $200 \mathrm{n} 2,201,201 \mathrm{n} 4,202,212$, 215, 215 n37, 216, 216 n40, 217, 217 n44, 218, 219, 219 n49, 220, 221, 236, 264, 266

Cadioli, Alberto: 38 n99

Caillois, Roger: 32, 32 n77, 71, 78, 78 n207

Calabrese, Stefano: 195 n244

Calvino, Esther: 87 n241

Calvino, Italo: 37, 49, 52, $52 \mathrm{n} 136,55$, 56, 78, 87, 87 n241, 93, 93 n256, 94 n257, 95, 95 n259, 148, 148 n126, $151 \mathrm{n} 133$

Calvo Sotelo, José: 155 n139

Calzoni, Raul: 44 n113

Camacho, Diego: v. Paz

Camba, Francisco: 118

Camilleri, Andrea: 67, 70, 70 n183, 224, 228 n65, 251, 266

Campanella, Fra' Tommaso (Giovanni): $235 \mathrm{n} 81$

Campesino, El: 42

Campi, Alessandro: 16 n25

Camus, Albert: 23, 23 n47, 23 n48, 24, 24 n49, 26, 56 n147, 150

Canali, Giulia: 117 n 49

Cancellieri, Natalia: 223 n56

Capa, Robert: 116 n44, 221

Caporilli, Pietro: 135 n95
Cappellini, Milva Maria: 267, 269

Cappello, Angelo Piero: 269

Carlotto, Massimo: 224, 224 n60, 250, 254, 266, 268

Carrière, Jean-Claude: 18 n29

Casadei, Alberto: 232, 232 n72, 266

Cassini, Marco: 209 n17

Cataluccio, Francesco M.: 79 n112

Caudwell, Christopher: 123 n65, 128 n78

Cavallo, Pietro: 131 n86, 136 n97

Cederna, Giuseppe: 200

Cela, Camilo José: 130

Cellini, Benvenuto: 120

Centovalli, Benedetta: 162 n 150

Cercas, Javier: 126 n73, 129, 130, 173, 173 n185, 219, 219 n47, 219 n48, 219 n49, 228, 228 n64, 233, 233 n74, 241, 242, 243

Cervantes, Miguel de: 214, 248

Cervi, Gino: 144

Ceserani, Remo: 212 n26

Céspedes, Alba de: 157, 170, 170 n177, $170 \mathrm{n} 178,171 \mathrm{n} 182,173,174,178$, 265

Cézanne, Paul: 167

Chacón, Dulce: 216, 216 n39, 267

Champagne, Élise: 154 n139

Chandler, Raymond: 34, 35

Chaplin, Charlie: 107, 107 n25

Chapsal, Madeleine: 119 n53

Chateaubriand, François-René de: 132 n90

Chiaberge, Riccardo: 117 n47, 123 n64

Chiara, Piero: 200 n3

Chiarini, Paolo: 197 n251

Chiosso, Renzo: 134 n91

Chiusano, Italo Alighiero: 198, 198 n252, 266

Christie, Agatha: 33,33 n83

Cialente, Fausta: 230, 230 n69

Claudel, Paul: 209

Coale, Robert: 268

Coco, Michele: 97 n263, 144 n120

Colacicchi, Piero: 99 n2

Coletti, Vittorio: 46 n119, 239, 239 n91

Collins, Larry: 252, 252 n127

Collo, Paolo: 243 n101, 267, 269

Colombel, Jeannette: 221 n52 
Colombo, Arturo: 212 n29

Comencini, Luigi: 108, 200

Comisso, Giovanni: 184

Conoscenti, Domenico: 67

Consolo, Vincenzo: 57 n151, 68 n175

Coppola, Aniello: 93 n255

Cordelli, Franco: 106 n22, 107 n26, 230 n69

Corman, Mathieu: 267

Corni, Gustavo: 44 n113, 252 n125

Corrado, Danielle: 235 n83, 268

Cortellessa, Andrea: 126 n72, 236 n85

Corti, Maria: 204 n5

Cotta Ramosino, Laura: 124 n67

Cotta Ramosino, Luisa: 124 n67

Cremonini, Giorgio: 107 n25

Crespi, Alberto: $201 \mathrm{n} 4$

Cristo: 63 n166, 101, 152, 176

Crovi, Raffaele: 118 n50, 162 n150, 163 n153

Curletto, Mario Alessandro: 124 n67

Curreri, Luciano: 27 n61, 38 n98, 54 n141, 116 n46, 132 n88, 184 n217, 204 n5, 208 n16, 211 n24, 235 n81, 235 n83, 239 n92, 262 n1

Curreri, Matteo: 7

Custine, Astolphe marqués de: 132 n90

Da Lentini, Giacomo: 51

Dallò, Gioietta: 42 n111

Dahrendorf, Ralf: 120 n55

Danelon, Fabio: 124 n67

Danna, Bianca: 134 n90

Davanzati, Chiaro: $51 \mathrm{n} 132$

David, Catherine: 18 n29

Davis, Mike: 44 n113

Deaglio, Enrico: 213 n33

De Amicis, Edmondo: 132, 132 n90, $134 \mathrm{n} 90$

D’Annunzio, Gabriele: 143, 182, 209, 210, 210 n20, 211

De Antoni, Maria Grazia: 156 n139

De Castris, Arcangelo Leone: 210, 210 n20, 211

De Cataldo, Giancarlo: 219 n49

De Chirico, Andrea: v. Savinio

De Curtis, Antonio: v. Totò

De Donato, Gigliola: 38 n100, 123 n65, $210 \mathrm{n} 20$
D’Eramo, Luce: 26, 26 n 57

De Federicis, Lidia: 12 n2, 13 n8, 38 n98, 116 n45, 142 n115, 211 n23, 266, 269

De Felice, Renzo: 137, 137 n102, 219, 219 n 46

De Filippo, Peppino: 88 n243

De Luna, Giovanni: 45 n113, 72 n191, 237, 237 n86, 252 n125

De Maria, Carlo: 145 n122

Debenedetti, Antonio: 257 n145

Debenedetti, Giacomo: 257 n 145

Debré, Michel: 112 n34

Degl'Innocenti, Maurizio: 94 n257, 248

Del Buono, Oreste: 106 n22, 266

Del Corno, Dario: 73, 73 n192

Del Giudice, Daniele: 257 n145

Deleuze, Gilles: 41 n107, 74 n196, 106 $\mathrm{n} 21$

Delfini, Antonio: 157, 160, 163, 163 n156, 163 n158, 164, 164 n160, 164 $\mathrm{n} 161,165,161 \mathrm{n} 162,161 \mathrm{n} 163,161$ n164, 161 n165, 169, 169 n165, 170, 174, 178, 185, 265, 267

Delfini, Giovanna: 164 n161

Delporte, Christian: 235 n81, 268 n3

Delumeau, Jean: 18 n29

Denis, Benoît: 207 n14, 268

Depaoli, Massimo: 162 n150

Derrida, Jacques: 27, 27 n61, 41 n107, $169 \mathrm{n} 176$

Dessí, Giuseppe: 46 n117, 179, 185, 185 n220, 186 n222, 187, 187 n223, 187 n226, 188, 266

Dethurens, Pascal: 115, 115 n41

Didier, Charles: 132 n90

Di Febo, Giuliana: 200 n2

Di Geronimo, Bruno: 67

Di Grado, Antonio: 17, 17 n27, 28, 28 $\mathrm{n} 65,34 \mathrm{n} 84,51,51 \mathrm{n} 133,55,55$ n143, 67, 67 n173, 80, 80 n217

Di Vanna, Corrado: 135 n96

Dickens, Charles: 149 n128

Dionisi, Stefano: 202 n5

Dognini, Cristiano: 124 n67

Dolfi, Anna: 27 n61, 46 n117, 165 n161, 179 n200, 186, 186 n222, 187, 187 n223, 187 n226, 204 n5, 266, 269 
Dolfi, Laura: 223 n55, 266

Doninelli, Luca: 207, 208, 208 n16, 209

d'Orsi, Angelo: 221 n52

Dos Passos, John: 63 n166, 99, 99 n2, 100, 101, 106, 107, 115, 245

Dostoievski, Fedor Mijailovich: 49, 49 n129, 56 n147, 212, 221 n52

Dumas, Alexandre (padre): 133 n90, 212

Dupin, Amandine-Lucie-Aurore: v. Sand

Duranti, Riccardo: 141 n112

Dürrenmatt, Friedrich: 85, 87, 90, 90 $\mathrm{n} 250,91 \mathrm{n} 251,92$

Durruti, Buenaventura: 211 n23, 234, $234 \mathrm{n} 78,235,235 \mathrm{n} 82$

Dzugasvili, Iosif Vissarionovich: v. Stalin

Eco, Umberto: 16 n25, 18 n29, 19, 37, 38, 38 n98, 39, 70, 198, 239, 239 n92, 266

Eisenstein, Serguéi Mijailovich: 107, 107 n25

Ejkenbaum, Boris: 80, 80 n218

Enzensberger, Hans Magnus: 56 n147, 113,113 n36, 114, 252 n127

Evangelisti, Valerio: 220, 220 n50, 236 n85, 240 n95, 266

Fabbro, Elena: 73 n192

Facco de Lagarda, Ugo: 34, 34 n86, 34 n87

Faenza, Roberto: 202 n5, 209 n17

Faeti, Antonio: 138 n106

Falaschi, Giovanni: 157, 157 n141

Farinella, Mario: 58 n151, 87 n240

Fast, Howard: 124 n 67

Felici, Glauco: 223 n57, 243 n102

Ferrante, Elena: 258

Ferraro, Bruno: 208 n16

Ferrer, Eulalio: 218

Ferrier, Jean-Luis: 247 n113

Ferroni, Giorgio: 255

Ferroni, Giulio: 38 n100, 154, 154 n136, 156 n140

Ferrucci, Franco: 77, 77 n203, 79 n215, 80,80 n 220

Ferruzza, Maria Lucia: $11 \mathrm{n} 1$

Festa, Francesco Saverio: 131 n86

Ficara, Giorgio: 235 n80
Filipazzi, Claudia: 269

Flaubert, Gustave: 107 n26

Florio, Aldo: 67, 72

Foa, Lisa: 107 n23

Foa, Renzo: 213 n33

Fofi, Goffredo: 23 n48, 79 n112, 129 n81, 155 n139, 219 n47

Fogazzaro, Antonio: 148 n126, 184

Foni, Fabrizio: 269

Fornaro, Pier Paolo: 124 n67

Forti, Marco: 50 n131

Fortini, Franco (Franco Lattes): 37, 38, 40,118 n50, 160 n 148

Fortini, Laura: 170, 173, 173 n185

Foucault, Michel: 16, 16 n24, 41 n107, 106 n 21

Franco, Francisco: 42 n111, 49, 59, 72, 89, 90, 108, 109, $112 \mathrm{n} 34,122,122$ n63, 130, 130 n85, 135, 135 n92, $137,158,159,179,185,186,188$, 190, 196, 197, 201, 204, 205, 208, 214, 220, 240 n94, 242 n100, 243 n104, 249, 256, 261

Franck, Dan: 244, 244 n106

Frank, Waldo: 154 n139

Frédéric, Madeleine: 258 n150

Friedrich, Jörg: 44 n113, 252 n125

Fruttero, Carlo: 52 n136

Fuentes, Carlos: 187

Gaglianone, Paola: 209 n17

Gallo, Claudio: 267

Gallone, Carmine: 249

Galzerano, Giuseppe: 246, 246 n110

Ganeri, Margherita: 212 n26

Garboli, Cesare: 164, 164 n161

Garbuglia, Daniele: 165 n164

García Berlanga, Luis: 200

García Lorca, Federico: 106, 107, 177, $178,205,221,221 \mathrm{n} 53,223,223$ n55

García Oliver, Juan: 234, 235 n79

Garibaldi, Giuseppe: 117 n49, 124 n67, 178,191

Garosci, Aldo: 89 n247, 103, 104, 118 n50, 129 n79, 131, 131 n87, 140, 140 n111, 141, 159, 159 n148, 162, 164, 169, 179, 179 n201, 180, 249, $249 \mathrm{n} 122$ 
Garro, Emilio: 137, 137 n100, 138 n104

Gaulle, Charles de: 111

Gautier, Théophile: 132 n90

Genina, Augusto: 135, 135 n96, 136, 140 n110, 261

Germano, Bruno: 126 n74

Gerratana, Valentino: 161 n150

Gervereau, Laurent: 116 n44

Gesù, Sebastiano: 68 n176, 72 n190, 84 n231

Ghislieri, Michele: v. Pio $V$

Giacovelli, Enrico: 144 n 119

Giannone, Antonio Lucio: 195 n246

Giartosio, Tommaso: 154 n138

Gibellini, Pietro: 124 n67

Gicca-Palli, Fulvio: 67

Gimmi, Annalisa: 188 n227

Ginzburg, Natalia: 34, 34 n85, 164 n161, 230 n68

Giordano, Valerio: 45 n113

Giovagnoli, Giorgio: 232 n71

Giovagnoli, Raffaello: 124, 124 n67

Gioviale, Fernando: 36 n95

Giral, José: 158

Girgenti, Salvatore: 78, 174

Giulianelli, Roberto: 234 n79

Glucksmann, André: 221 n52, 238, 238 n88

Godard, Jean-Luc: 111

Godicheau, François: 268

Goethe, Johann Wolfgang: 168

Gogol, Nikolai Vasilievich: 144

Gómez, Julián: v. Gorkin

González, Valentín: v. Campesino

González Martín, Vicente: 42 n110

Goretti, Gianfranco: 154 n138

Gorkin, Julián: 216 n40

Gould, Stephen Jay: 18 n29

Gousseau, Josette: 76, 76 n201

Goytisolo, Juan: 223, 223 n57, 233, 240

Gozzano, Guido: 49, 50 n130, 53

Gramsci, Antonio: 124 n67, 150

Grassi, Piergiorgio: 92 n252

Greco, El: 167, 168

Green, Nan: 217

Greene, Graham: 33, 33 n82

Gribaudi, Gabriella: 45 n113

Grillo, Rosa Maria: 131 n86

Griner, Massimiliano: 193 n238
Guareschi, Giovannino: 108, 148 n126

Guarnieri, Silvio: 158 n144

Guglielminetti, Marziano: 152 n135

Guillén, Jorge: 42

Guttuso, Renato: 157 n141, 159, 160, 161 n149

Halbwachs, Maurice: 74

Hanimann, Joseph: 237 n87, 238

Hawks, Howard W.: 34

Hemingway, Ernest: 9, 33, 45, 96, 100, $100 \mathrm{n} 4,101,101 \mathrm{n} 5,102 \mathrm{n} 8,103$, $104,105,105 \mathrm{n} 17,106,106 \mathrm{n} 22$, 107, 107 n26, 113, 114, 115, 118 n52, 123, 129, 132, 132 n89, 137, 139, 140, 144 n118, 148, 149, 157, $174,178,213,221,224,228,244$, 267

Hermet, Guy: 14 n13, 94 n257

Heydenreich, Titus: 23 n48

Hillman, James: 75, 75 n199

Hitler, Adolf: 91, 92, 93, 208, 211 n23, 214, 234, 235, 252, 252 n 126

Hobsbawm, Eric J.: 215 n38

Hollier, Denis: 78 n208

Horkheimer, Max: 61, 61 n160

Husserl, Edmund: 47, 47 n120

Ibárruri, Dolores: v. Pasionaria

Ilardi, Massimo: 50 n129

Isaia, Nino: 213 n33, 214 n35

Isotti Rosowsky, Giuditta: 137 n101

Iutkevich, Serguéi I.: 107 n25

Ivekovic, Rada: 265, 265 n2

Jackson, Gabriel: 214, 245 n108

Jankélévitch, Vladímir: 108 n29, 142 n113,146 n124, 147 n125

Jesi, Furio: 211, 211 n24, 251 n124

Jorge II (rey de Grecia): 228

Jossa, Stefano: 126 n72, 195 n244

Jovine, Francesco: 62, 97 n263, 141, 142,142 n114, 142 n115, 142 n116, 144, 144 n120, 146, 147, $154,155,156,178,179,194,266$, 267

Kempowski, Walter: 44 n113

Kesten, Hermann: 213 n32 
Koestler, Arthur: 120, 120 n55, 120 n56, 120 n57, 120 n58, 121, 121 n62, 122 n63, 123, 124, 124 n67, 128, $128 \mathrm{n} 77,139,215,218,242$, 253

Koltsov, Mijaíl: 42, 42 n111, 100 n4

Kosinzev, Grigori M.: 107 n25

Kowalsky, Daniel: 109 n31

Kristeva, Julia: 56 n146

Kruschov, Nikita Sergeevich: 22 n46, 87, 92, 94 n257, 108

Kuby, Erich: 253

Kubrick, Stanley: 124 n67

Lahire, Bernard: 40, 41 n107

Lajolo, Davide: 189, 192, 192 n237, 193, 193 n238, 193 n239, 193 n241, 194, 194 n242, 195 n245, 198, 249, 266

Lambertini, Próspero: v. Benedicto XIV

Lapierre, Dominique: 252, 252 n127

Largo Caballero, Francisco: 155 n139

Lasch, Christopher: 112 n35

Lauterbach, Arlette: 224 n59

Lavagetto, Mario: 39

Le Bras, Charles: 14 n13

Lefere, Robin: 131 n85

Lenin: 113

Lenoir, Frédéric: 18 n29

Leoncini, Francesco: 269

Leone, Sergio: 105, 105 n18

Leonetti, Francesco: 37

Lesfargues, Bernard: 141 n111

Linati, Carlo: 154 n139, 266

Lincoln, Bruce: 22 n46

Linder, Erich: 130, 130 n82

Linze, Georges: 258 n150

Líster, Enrique: 42, 174, 175, 177

Llorens, Antonio: 84, 84 n231

Loach, Ken: 201, 201 n4, 232

Lombardo, Giovanna: 130 n82

Longo, Davide: 228 n65

López Mondéjar, Publio: 214

Loraux, Nicole: 21 n39, 74 n194

Lucarelli, Carlo: 142 n114, 194, 194 n243, 200, 201, 202, 212, 221, 224, 224 n59, 236, 245, 248 n115, 250, 254, 259, 264, 266, 267, 268

Lumière, Auguste y Louis: 68
Lunacharsky, Anatoli Vasilievich: 211

Luperini, Romano: 37, 38 n98, 39, 39 n103, 40

Lussu, Emilio: 195

Lussu Salvadori, Joyce: 189, 195, 196 n248, 197, 197 n250, 266

Luti, Giorgio: 157 n141

Luxardo Franchi, Piero: 164 n160

Luzi, Mario: 162 n150

Lyotard, Dolorès: 27 n61

Lyotard, Jean-François: 27 n61

Mac Arthur, Douglas Arthur: 124 n67

Maccari, Ruggero: 144

Machado, Antonio: 35

MacLeish, Archibald: 20

Macrí, Oreste: 27 n61, 162 n150, 163, 163 n 155,179 n200

Madrignani, Carlo Alberto: $11 \mathrm{n} 2,13$, $13 \mathrm{n} 8,13 \mathrm{n} 9,16 \mathrm{n} 22,19,20 \mathrm{n} 35$, 67, 67 n172, 83, 83 n228, 134 n90

Maffi, Mario: 33, 33 n81, 35 n90, 140 n109, 149 n128

Maffia, Dante: 235 n81

Maffioli, Giuseppe: 34

Maggi, Gianfranco: 269

Magnan, Pierre: 224, 224 n59

Magris, Claudio: 116 n46, 204 n5, 208 n16, 237, 238, 238 n89, 239, 239 n92, 239 n93, 240 n96, 241, 264, 266, 268

Maigron, Maryline: 258 n 147

Mainer, José Carlos: 118 n51, 130 n83, 200 n2, 220 n51, 268

Maiakovski, Vladímir Vladimirovich: 209

Malaparte, Curzio: 249

Malraux, André: 42, 42 n111, 54, 54 $\mathrm{n} 140,57,58 \mathrm{n} 151,63,63 \mathrm{n} 165,64$ n168, 85, 85 n232, 96, 96 n261, 100 $\mathrm{n} 4,101,101 \mathrm{n} 7,103,104,105,105$ n16, 106, 106 n21, 111, 123, 124, 139, 140, 140 n110, 148, 149

Manera, Danilo: 216 n39, 243 n103

Manfredi, Nino: 144, 147

Manganaro, Paolo: 19, 19 n33, 20, 20 n37

Manica, Raffaele: 165 n161

Mann, Thomas: 213 n32 
Mantovani, Vincenzo: 118 n52

Manzoni, Alessandro: 20, 21, 45, 156, 237

Marcel, Gabriel: 14 n13

Marchetti, Giuseppe: 163 n157, 164 n 158

Marcuse, Herbert: 47 n120, 61 n160

Mare, Monica: 156 n139

Mari, Michele: 257

Marías, Javier: 243, 243 n102, 243 n 104

Marinetti, Filippo Tommaso: 206, 209, 210

Martínez de Pisón, Ignacio: 245, 245 n107

Marty, André: 100

Marx, Karl: 27 n61, 89, 94 n257, 109, 123 n65, 164

Maspero, François: 215 n37

Massot i Muntaner, Josep: 246, 246 n111

Mastroianni, Marcello: 202 n5

Matteotti, Giacomo: 61, 156 n139, 181, $211,211 \mathrm{n} 23$

Maugeri, Marco: 211, 211 n23

Maupassant, Guy de: 212

Mauriac, François: 14 n13, 212

Mauron, Charles: 31, 46, 46 n118, 73

Mazzacurati, Carlo: 184

McCarthy, Joseph: 22 n46, 91, 150

Méndez, Alberto: 245, 245 n107

Menozzi, Daniele: 138 n 105

Mercader, Luis: 216 n40

Mercader, Ramón: 216 n40

Mérimée, Prosper: 132 n90

Merleau-Ponty, Maurice: 13, 14, 14 n13, $14 \mathrm{n} 15,14 \mathrm{n} 16,15 \mathrm{n} 18,20,20 \mathrm{n} 44$, $31,55,69,69 \mathrm{n} 181,114,114 \mathrm{n} 39$

Merquior, José Guilherme: 41 n107

Messina, Simone: 176 n 194

Metaxas, Joannis: 228

Mileschi, Christophe: 235 n81, 257 n145, 266

Milner, Jean-Claude: 21 n39, 27 n61, 74 n194

Milner, Max: 22 n45, 204 n7

Mininni, Francesco: 195 n18

Minoia, Carlo: 158 n144

Mitterand, François: 112 n34

Mizzella, Stefano: 45 n113
Modotti, Tina: 119 n54, 189 n230, 199, $200 \mathrm{n} 2,201,215,216,216 \mathrm{n} 40,221$

Molotov, Vyacheslav: 92

Mommsen, Hans: 21 n39, 74 n194

Mondragón, Carmen: v. Nahui Olin

Monnier, Adrienne: 256, 256 n 144

Montale, Eugenio: 49, 50, 50 n131, 53, $53 \mathrm{n} 138$

Montand, Yves: 109

Montanelli, Indro: 213 n33, 214 n35, 266

Monteleone, Enzo: 71

Montero, Rosa: 240

Mora, Constancia de la: 42, 42 n111

Morandi, Aldo: 246, 246 n 110

Morandini, Giuliana: 204 n5

Moravia, Alberto: 38, 39, 107, 108 n26

Moreno Juliá, Xavier: 122 n63, 214 n34

Moretti, Franco: 138 n106

Morino, Angelo: 232, 233 n73, 233 n76

Moro, Aldo: 37, 38 n99

Moro, Renato: 138 n 105

Morreale, Emiliano: 67, 67 n174, 68, 69 n178

Moscardó, José: 135 n95

Muñoz Molina, Antonio: 240, 240 n94

Murat, Laure: 256 n144

Musil, Robert: 107, 108 n26

Mussolini, Benito: 24, 25, 45, 60, 62, 72, 79, 131, 132, 137 n102, 145 n122, 151 n134,m 159, 183, 185, $188,192,194,198,210,211,219$ n46, 246, 246 n110, 248

Naas, Michael: 27 n61

Nahui Olin: 216, 216 n40

Napolitano Martone, Maria: 102

Natoli, Claudio: 200, 200 n2

Nay, Laura: 152 n135

Nazzari, Amedeo: 136

Negrín, Juan: 114

Neiger, Ada: 46 n117

Nelken, Margarita: 217

Némirovsky, Irène: 252 n126

Nenni, Pietro: 42, 42 n111, 180

Neppi, Enzo: 266

Neruda, Pablo: 118, 118 n50

Nesi, Cristina: 162 n 150

Nievo, Ippolito: 237 
Nisticò, Vittorio: 87 n240

Nitti, Francesco Fausto: 131, 179, 179 n202, 180, 181, 187, 266, 267

Nocita, Salvatore: 147

Noiriel, Gérard: 112 n34

Nothomb, Paul: 105 n16

Nyssen, Hubert: 141 n111, 267

Oms, Marcel: 109 n32, 140 n110, 241 n99

Onofri, Massimo: 39 n101, 96, 126 n72, 195 n244

Ortega y Gasset, José: 224 n60

Orwell, George: 26 n57, 33, 33 n81, 35, 36, $36 \mathrm{n} 94,42,42 \mathrm{n} 111,57,101$, 139, 140, 140 n109, 141, 141 n112, $148,149,149 \mathrm{n} 128$

Ostellino, Piero: 213 n33

Ovejero, José: 240, 240 n97, 241 n98

Paci, Enzo: 14 n13, 47, 47 n120

Pajetta, Giancarlo: 232 n71

Palacio, Léo: 114 n38, 146 n122

Palumbo, Giovanni: 53 n137

Palumbo, Giuseppe: 224 n60

Palumbo, Matteo: 88 n243

Panafieu, Yves: 71, 71 n186

Panicali, Anna: 157 n141

Papini, Maria Carla: 204 n5

Papponetti, Giuseppe: 26, 26 n57, 269

Papuzzi, Alberto: 18 n29

Papy, Michel: 217 n43, 245 n108

Parise, Goffredo: 179, 181, 181 n207, 182, 184, 184 n218, 185, 185 n219, $186,187,187$ n225, 266

Parisot, Henri: 137 n101

Parnet, Claire: 74 n 196

Pasinato, Antonio: 212 n29, 213 n32

Pasionaria, La: 118 n50, 150

Pasolini, Pier Paolo: 30, 37, 38, 39, 40, 52, 73, 73 n192, 236, 264, 266

Pastor, Ben: 221, 221 n54, 223, 223 n58

Pautasso, Sergio: 157 n141

Pauwels, Louis: 251, 251 n123

Pavese, Cesare: 150, 150 n130, 151, 151 n134, 152 n135, 154, 155, 156, 178, 266

Pavolini, Luca: 42 n111

Pavone, Claudio: 201 n3
Paz, Abel: 234

Pazzi, Roberto: 204 n5

Pecoraro, Zino: 19 n33

Pederiali, Giuseppe: 188

Pellini, Pierluigi: 70 n185

Pellizzi, Camillo: 122 n63

Pent, Sergio: 216 n40, 221 n53

Pépin, Patrick: 216 n39

Pérez-Díaz, Víctor: 243 n104

Perosa, Sergio: 100, 101 n5

Perrone, Domenica: 38 n100, 42 n110, 81 n223, 82 n224, 83 n225, 95 n260

Perrone, Vincenzo: 246 n 110

Pessoa, Fernando: 210, 215 n36

Petrignani, Pietro: 123 n63

Picasso, Pablo: 247, 247 n113

Picelli, Guido: 189, 192

Pichois, Claude: 100 n4

Picon, Gaëtan: 78 n207, 85 n232

Pignatelli, Valerio: 135 n95

Pincherle, Alberto: v. Moravia

Pintor, Giaime: 161, 161 n150

Pío V: 137

Pirandello, Luigi: 12 n7, 13 n12, 209, 210, $210 \mathrm{n} 20,211,211 \mathrm{n} 22$

Pirani, Mario: 213 n33

Pirani, Roberto: 156 n139

Platón: 16 n25, 18 n29, 22, 22 n45, 24, 30, 40, 68, 236, 264

Pohorylle, Gerta: v. Taro

Polidoro, Maria Teresa: 267, 269

Pompeo Faracovi, Ornella: 14 n15

Porzio, Domenico: 93 n254

Pratolini, Vasco: 162 n 150

Praz, Mario: 155 n139

Preston, Paul: 135 n92, 214, 217, 217 n42

Primo de Rivera, José Antonio: 138 n105, 177

Proust, Marcel: 119

Puccini, Mario: 155 n139, 266

Pupo, Ivan: 211 n22

Quattrini, Antonio G.: 159, 159 n146

Queipo de Llano, Gonzalo: 158, 159

Quondam, Amedeo: 90 n249

Raffaelli, Massimo: 124 n67

Raimondi, Ezio: 20 n38, 126 n74 
Ramat, Silvio: 164 n160

Ramella, Pietro: 246, 246 n110

Ramondino, Fabrizia: 9, 105 n20, 126 $\mathrm{n} 73,212,212 \mathrm{n} 28,228,230,230$ n68, 231 n70, 246, 246 n112, 249, 257, 257 n146, 258, 258 n147, 258 n148, 258 n152, 259, 266, 267, 268, 269

Ranzato, Gabriele: 45, 45 n114, 104 n13, 104 n14, 108 n27, 114 n38, 156 n139, 200 n2, 201 n4, 221 n52, 245 n 108

Rapone, Leonardo: 200, 200 n2

Rasy, Elisabetta: 211, $211 \mathrm{n} 23$

Regler, Gustav: 213, 213 n32, 267

Rèpaci, Leonida: 187, 189, 266

Resnais, Alain: 109, 110, 111, 113

Reyes Basoalto, Ricardo Neftalí: v. Neruda

Ribadeau, François-Marie: 258

Ribbentrop, Joachim von: 92

Ricciardi, Mario: 126 n74

Richard, Jean-Pierre: 262

Richard, Lionel: 255

Ricœur, Paul: 15 n17, 21, 21 n43, 27 n60, 27 n62, 28, 28 n64, 54 n142, 74, 74 n195, 75 n197, 85 n233

Ricorda, Ricciarda: 36, 42 n110

Ricuperati, Giuseppe: 21 n43, 116 n46, 236, 236 n84, 237

Rigoni Stern, Mario: 106 n22

Rilke, Rainer Maria: 168

Rimbaud, Arthur: 50

Rivalta, Romeo: 136, 261

Rivera, Diego: 216 n40

Robles Pazos, José: 245

Robotti, Paolo: 93, 93 n254, 94 n257

Rocca, Daniele: 221

Roche, Daniel: 40 n106

Rodondi, Raffaella: 162, 214 n35

Rohmer, Eric: 220

Romano, Sergio: 213 n33, 214

Romilly, Esmond: 218, 218 n45

Roosevelt, Franklin Delano: 109

Rosselli, Carlo: 234

Rosso, Renzo: 46

Rossif, Frédéric: 119, 119 n53

Rougemont, Denis de: 78

Rousseau, Jean-Jacques: 120
Rovatti, Pier Aldo: 15 n21, 18 n28, 19, $19 \mathrm{n} 34,29,68,30,31,31 \mathrm{n} 75,48$ n124, 69, 69 n179, 69 n182, 169 n176

Runcini, Romolo: 149 n128

Rushdie, Salman: 237 n87

Sabaté, Francisco: 218

Sabbatino, Pasquale: 88 n 243

Sacco, Nicola: 99, 99 n2, 101, 114

Sacerdoti Mariani, Gigliola: 212 n29

Salazar, António de Oliveira: 202, 204, 211,214

Salerno, Enrico Maria: 72

Salgari, Emilio: 71, 132, 132 n88, 134, 136

Salinari, Carlo: 210, 210 n20, 211

Salmon, Christian: 237 n87, 238

Salvati, Michele: 243 n 104

Sánchez, Germán: 216 n40

Sánchez Mazas, Rafael: 129

Sand, George: 132 n90

Sanguineti, Edoardo: 204 n5

Sanvitale, Francesca: 204 n5

Sanz-Bachiller, Mercedes: 217

Sapegno, Natalino: 13 n10, 127 n74

Sarrabayrouse, Alain: 235 n81, 257 n145, 258 n 147

Sarti, Emanuela: 246 n111

Sartre, Jean-Paul: 40 n105, 41, 106 n21, 207, 207 n14, 267

Saura, Carlos: 124, 124 n66, 130, 241, $241 \mathrm{n} 99,242$ n100

Savinio, Alberto: 137 n101

Sbarberi, Franco: 18 n29

Scalabrin, Paolo: 7

Scarpa, Luciano: 71, 150

Scarponi, Alberto: 212 n30

Scarry, Elaine: 44 n 113

Scarsella, Alessandro: 34 n86

Schaber, Irme: 215 n37

Schivelbusch, Wolfgang: 44 n113

Schneider, Helga: 252, 252 n127

Schubert, Franz Peter: 168

Scianna, Ferdinando: 15 n20, 176

Scognamiglio, Giuseppina: 88 n243

Scola, Ettore: 34, 144, 200

Scott-Ellis, Priscilla: 217

Scotti, Francesco: 192, 192 n238 
Scotto Di Luzio, Adolfo: 138 n106

Scrivano, Enzo: 19 n33

Scrivano, Riccardo: 209 n17

Sebald, Winfried Georg: 44 n113, 71, 71 n187, 252 n 125

Segre, Cesare: 50, 50 n131

Semprún, Jorge: 105 n16, 109 n32, 110, 111, 216 n40, 244, 244 n105

Sender, Ramón José: 89 n247, 140, 140 n111, 267

Serra, Maurizio: 127, 127 n75, 129 n80, 213 n32, 246 n 109

Serrano, Carlos: 44 n112, 118 n51, 220 n51

Sfez, Gérald: 27 n61

Shakespeare, William: 123 n65, 212, 212 n 29

Sighinolfi, Paolo: 132, 134, 134 n92, $135,135 \mathrm{n} 93,136,137,138,138$ n103, 181, 194, 261

Silone, Ignazio (Secondo Tranquilli): 26, 26 n57, 119, 120, 120 n55, 139, 139 n107, 145, 145 n120, 147

Simon, Claude: 111, 138 n106

Sini, Carlo: 15 n21

Skoutelsky, Rémy: 117 n49

Skrijabin, Viacheslav Mijailovich: v. Molotov

Sodini, Carla: 212, 212 n29

Sofri, Adriano: 18 n29, 28 n63

Sofri, Gianni: 120 n56, 128 n77

Sogno, Edgardo: 213 n33, 214 n35

Soler, Antonio: 130, 130 n84, 242, 243, 243 n101, 250, 259

Sontag, Susan: 39, 44 n113, 116, 116 n43, 116 n44, 253 n131

Soria Millán, María Pilar: 240, 240 n97

Sorrentino, Christian: 36 n96

Soutworth, Herbert R.: 221 n52, 247 n114, 268

Soyinka, Wole: $237 \mathrm{n} 87$

Sozzi, Lionello: 12 n4, 24 n51, 26 n59

Spagnoletti, Giacinto: 50 n130

Spalanca, Carmelo: 90 n249

Spartaco: 99 n2, 122, 124, 124 n67

Spender, Stephen: 117 n47, 123 n64, 123 n65, 128, 128 n78, 247

Spinazzola, Vittorio: 38 n98, 162, 162 n151
Spinelli, Barbara: 212 n33

Sprigger, Ch. St. John: v. Caudwell

Stalin: 22 n46, 85, 87, 87 n241, 88, 88 n244,89, 89 n247, 90, 91, 92, 92 n253, 93, 93 n256, 94. 94 n257, 95, $95 \mathrm{n} 259,97,109,109 \mathrm{n} 31,118,118$ n50, 119, 120, 121, 123, 151 n133, $201 \mathrm{n} 4,263$

Stauder, Thomas: 116 n46, 208 n16, 239 n92, 268

Stegagno Picchio, Luciana: 208 n16, 239, 239 n90

Steiner, George: 39, 168, 168 n174

Stendhal: 60, 256, 266

Steno: 88

Subor, Michel: 111

Suckert, Cuzio: v. Malaparte

Svevo, Italo: 107, 108 n26, 210 n20

Swift, Jonathan: 105

Tabucchi, Antonio: 16 n25, 18 n29, 28 n63, 29, 30, 30 n70, 30 n71, 37 n97, 40, 40 n104, 116 n 46,140 n108, 196, 196 n249, 198, 202, 202 n5, 204 n5, 204 n6, 204 n8, 207, 207 n14, 208, 208 n16, 209 n17, 209 n18, 210, 210 n19, 210 n21, 211, $211 \mathrm{n} 25,212,212$ n26, 212 n27, 212 n29, 212 n30, 213, 213 n33, 214, $214 \mathrm{n} 35,215,215 \mathrm{n} 36,218$, 219, 236, 237, 238, 239 n92, 264, 265, 266, 268, 269

Tadini Perazzoli, Antonia: 244 n106

Talarico, Vincenzo: 144

Taro, Gerda: 215 n37

Tartaro, Achille: 126 n74

Tedesco, Natale: 15 n20, 42 n110, 48, $48 \mathrm{n} 123,52 \mathrm{n} 135,55 \mathrm{n} 145,82$ n224, 95 n260, 104 n14

Temine, Émile: 118 n 51

Terni, Paolo: 230 n69

Tesio, Giovanni: 52 n136, 200 n3

Testa, Enrico: 17 n26, 46, 46 n119

Theotocópulos, Doménico: v. Greco

Theweleit, Klaus: 154 n138

Thomas, Hugh: 218 n 45

Todorov, Tzvetan: 27 n62, 30 n71, 40, $80 \mathrm{n} 218$

Tolstoi, Lev Nikolaievich: 212 
Tomasi di Lampedusa, Giuseppe: 12 n7, 13, 13 n12, 19, 19 n31

Tomasinelli, Paola: 242 n100, 243 n101

Tonnac, Jean-Philippe de: 18

Tornatore, Giuseppe: 68

Totò: $70,88,88$ n243

Traina, Giuseppe: 17, 35, 35 n92, 36 n95, 39 n101, 45 n116, 52 n136, 57 n149, 57 n151, 70, 70 n183, 72 n188, 78 n209, 82 n224, 83, 83 n227, 84 n229, 85 n235, 86 n239, 90 n247, 90 n249, 93, 93 n254, 96 n261, 98, 98 n264, 266, 269

Tranquilli, Secondo: v. Silone

Trapiello, Andrés: 173

Trécourt, François: 140

Trentini, Nives: 202 n5, 209, 209 n18, 210, 212 n26

Trevi, Emanuele: 252 n 125

Trotsky, Lev Davidovich: 216 n40

Trueba, David: 219 n47

Truman, Harry: 150

Truppi, Carlo: 75 n199

Tyras, Georges: 36 n96

Ucelay-Da Cal, Enric: 200 n2

Ughi, Stefanella: $201 \mathrm{n} 4$

Ulianov, Vladímir Ilich: v. Lenin

Ungarelli, Giulio: 164 n158

Urso, Simona: 138 n 106

Valiani, Leo: 120 n56

Vallès, Sophie: 217 n 43

Valli, Alida: 136

Van Hensbergen, Gijs: 247 n113

Vanzetti, Bartolomeo: 99, 99 n2, 101, 114

Vanzina, Stefano: v. Steno

Vattimo, Gianni: 21 n39, 74 n194

Vecellio, Valter: 93 n255

Velázquez, Diego Rodríguez de Silva y: 167

Venturi, Gianni: 150 n130

Venza, Claudio: 145 n122, 153, 246, 246 n 110
Verestin, Nino: 159, 159 n146

Verga, Giovanni: 13 n12, 14 n14, 75, 76,143

Vidali, Vittorio: 42 n111

Vigorelli, Giancarlo: 13

Vilar, Pierre: 221 n52, 268

Villa, Pancho: 216 n40

Viola, Sandro: 213 n33

Visconti, Luchino: 148, 148 n126

Visentini, Olga: 138, 138 n 106

Vitali, Andrea: 200 n3

Vittorini, Elio: 38 n100, 42, 42 n110, 79, 79 n213, 80, 81, 81 n222, 81 n223, 82, 82 n224, 83, 83 n225, 85, 87, 95 n260, 103, 118, 118 n50, 134, 150, $151 \mathrm{n} 132,156,157,157$ n141, 158, 158 n144, 159, 159 n148, 160 n148, 161 n149, 161 n150, 162, 163, 163 n153, 163 n155, 164, 167, 169, 170, 174, 177, 178, 185, 187, 187 n224, 263, 265, 269

Volponi, Paolo: 37, 38

Vonnegut, Kurt: 56 n147

Walzer, Michael: 16, 16 n24, 23 n47, 24 n49, 24 n52, 26 n58, 29 n66, 41 n107

Wells, Herbert George: 115 n42

Wilson, Edmund: 115

Winnicott, Donald W.: 258 n 150

Wright, Richard: 137, 137 n99

Yerushalmi, Yosef Hayim: 21, 21 n39, 28 n64, 54 n142, 74 n194

Yusta, Mercedes: 268

Zago, Nunzio: 13 n12, 39 n102, 51, 51 n134

Zambrano, María: 265 n2

Zampa, Luigi: 144, 144 n119, 146, 147, 148

Zapata, Emiliano: 216 n 40

Zei, Alki: 228, 230 n66

Zollino, Antonio: 53 n138, 269 


\section{ÍNDICE}

"DÁBAMOS VUELTAS EN TORNO A MADRID COMO LAS MARIPOSAS, DE NOCHE, EN TORNO A LA LLAMA». PREMISAS Y CONSECUENCIAS SCIASCIANAS....

1. Historia, filosofía, crítica social y compromiso político: aproximaciones a una ética del lenguaje en El antimonio (1960).

2. Contra el síndrome del último intelectual y la exigencia de totalidad

3. «Sabéis qué ha sido la Guerra de España? ¿Lo que ha sido de verdad?»

4. "Mariposas en torno a la llama». Breve historia de una imagen

5. El fuego, el miedo, la memoria, la infancia y «los muchachos hambrientos, con hambre de ciudades nuevas y de ver mundo»

6. Conclusiones provisionales y aperturas.

UN CUARTO DE SIGLO DE TRADICIONES PERDIDAS (1936-1960) Y UNA RÁPIDA INCURSIÓN

1. «Y encima, me gusta charlar». Problemas de un discurso literario sobre la guerra civil española y concatenaciones del imaginario entre pasado y presente

2. Antes de Sciascia. ¿'Tradiciones perdidas o inexistentes?........ 127

3. Después de El antimonio. Una rápida incursión................... 188 
ENTRE MADRID Y GUERNICA. ACTUALIZACIONES SOBRE LA NARRATIVA ITALIANA, LA GUERRA DE ESPAÑA Y SUS CIUDADES HERIDAS (1991-2006)..........

1. Hoy: límites cronológicos e hipotéticas reseñas entre los siglos XX y XXI

2. Apuntes sobre el regreso de la guerra civil española en otros narradores italianos y extranjeros (traducciones, entrevistas, recensiones)

3. Novelas, relatos y recorridos temáticos: Madrid, Guernica y otras ciudades heridas en la narrativa italiana 
Este libro se terminó de imprimir en los talleres gráficos

de INO Reproducciones, S. A., de Zaragoza, el día 6 de mayo de 2009

go 



\section{Títulos de la colección Humanidades}

1 Joaquín Lomba Fuentes, El oráculo de Narciso. (Lectura del Poema de Parménides), 2. ${ }^{\mathrm{a}}$ ed. (1992).

2 Luis Fernández Cifuentes, García Lorca en el Teatro: La norma y la diferencia (1986).

3 Ignacio Izuzquiza Otero, Henri Bergson: La arquitectura del deseo (1986).

4 Gabriel Sopeña Genzor, Dioses, ética y ritos. Aproximación para una comprensión de la religiosidad entre los pueblos celtibéricos (1987).

5 José Riquelme Otálora, Estudio semántico de purgare en los textos latinos antiguos (1987).

6 José Luis Rodríguez García, Friedrich Hölderlin. El exiliado en la tierra (1987).

7 José María Bardavío García, Fantasías uterinas en la literatura norteamericana (1988).

8 Patricio Hernández Pérez, Emilio Prados. La memoria del olvido (1988).

9 Fernando Romo Feito, Miguel Labordeta. Una lectura global (1988).

10 José Luis Calvo Carilla, Introducción a la poesía de Manuel Pinillos. Estudio y antología (1989).

11 Alberto Montaner Frutos, Política, historia y drama en el cerco de Zamora. La Comedia segunda de las mocedades del Cid de Guillén de Castro (1989).

12 Antonio Duplá Ansuategui, Videant consules. Las medidas de excepción en la crisis de la República Romana (1990).

13 Enrique Aletá Alcubierre, Estudios sobre las oraciones de relativo (1990).

14 Ignacio Izuzquiza Otero, Hegel o la rebelión contra el limite. Un ensayo de interpretación (1990).

15 Ramón Acín Fanlo, Narrativa o consumo literario (1975-1987) (1990).

16 Michael Shepherd, Sherlock Holmes y el caso del Dr. Freud (1990).

17 Francisco Collado Rodríguez (ed.), Del mito a la ciencia: la novela norteamericana contemporánea (1990).

18 Gonzalo Corona Marzol, Realidad vital y realidad poética. (Poesía y poética de José Hierro) (1991).

19 José Ángel García Landa, Samuel Beckett y la narración reflexiva (1992).

20 Ángeles Ezama Gil, El cuento de la prensa y otros cuentos. Aproximación al estudio del relato breve entre 1890 y 1900 (1992).

21 Santiago Echandi, La fábula de Aquiles y Quelone. Ensayos sobre Zenón de Elea (1993).

22 Elvira Burgos Díaz, Dioniso en la filosofía del joven Nietzsche (1993).

23 Francisco Carrasquer Launed, La integral de ambos mundos: Sender (1994).

24 Antonio Pérez Lasheras, Fustigat mores. Hacia el concepto de la sátira en el siglo XVII (1994).

25 M. ${ }^{a}$ Carmen López Sáenz, Investigaciones fenomenológicas sobre el origen del mundo social (1994).

26 Alfredo Saldaña Sagredo, Con esa oscura intuición. Ensayo sobre la poesía de Julio Antonio Gómez (1994).

27 Juan Carlos Ara Torralba, Del modernismo castizo. Fama y alcance de Ricardo León (1996).

28 Diego Aísa Moreu, El razonamiento inductivo en la ciencia y en la prueba judicial (1997). 
29 Guillermo Carnero, Estudios sobre teatro español del siglo XVIII (1997).

30 Concepción Salinas Espinosa, Poesía y prosa didáctica en el siglo XV: La obra del bachiller Alfonso de la Torre (1997).

31 Manuel José Pedraza Gracia, Lectores y lecturas en Zaragoza (1501-1521) (1998).

32 Ignacio Izuzquiza, Armonía y razón. La filosofía de Friedrich D. E. Schleiermacher (1998).

33 Ignacio Iñarrea Las Heras, Poesía y predicación en la literatura francesa medieval. El dit moral en los albores del siglo XIV (1998).

34 José Luis Mendívil Giró, Las palabras disgregadas. Sintaxis de las expresiones idiomáticas y los predicados complejos (1999).

35 Antonio Armisén, Jugar y leer. El Verbo hecho tango de Jaime Gil de Biedma (1999).

36 Abū ț Tāhir, el Zaragozano, Las sesiones del Zaragocí. Relatos picarescos (maqāmāt) del siglo XII, estudio preliminar, traducción y notas de Ignacio Ferrando (1999).

37 Antonio Pérez Lasheras y José Luis Rodríguez (eds.), Inventario de ausencias del tiempo despoblado. Actas de las Jornadas en Homenaje a José Antonio Rey del Corral, celebradas en Zaragoza del 11 al 14 de noviembre de 1996 (1999).

38 J. Fidel Corcuera Manso y Antonio Gaspar Galán, La lengua francesa en España en el siglo XVI. Estudio y edición del Vocabulario de los vocablos de Jacques de Liaño (Alcalá de Henares, 1565) (1999).

39 José Solana Dueso, El camino del ágora. Filosofía politica de Protágoras de Abdera (2000).

40 Daniel Eisenberg y M. ${ }^{a}$ Carmen Marín Pina, Bibliografía de los libros de caballerías castellanos (2000).

41 Enrique Serrano Asenjo, Vidas oblicuas. Aspectos históricos de la nueva biografía en España (192-1936) (2002).

42 Daniel Mesa Gancedo, Extraños semejantes. El personaje artificial y el artefacto narrativo en la literatura hispanoamericana (2002).

43 María Soledad Catalán Marín, La escenografia de los dramas románticos españoles (1834-1850) (2003).

44 Diego Navarro Bonilla, Escritura, poder y archivo. La organización documental de la Diputación del reino de Aragón (siglos XV-XVIII) (2004).

45 Ángel Longás Miguel, El lenguaje de la diversidad (2004).

46 Niall Binns, ¿Callejón sin salida? La crisis ecológica en la poesía hispanoamericana (2004).

47 Leonardo Romero Tobar (ed.), Historia literaria / Historia de la literatura (2004).

48 Luisa Paz Rodríguez Suárez, Sentido y ser en Heidegger. Una aproximación al problema del lenguaje (2004).

49 Evanghélos Moutsopoulos, Filosofía de la cultura griega, traducción de Carlos A. Salguero-Talavera (2004).

50 Isabel Santaolalla, Los «Otros». Etnicidady «raza» en el cine español contemporáneo (2005).

51 René Andioc, Del siglo XVIII al XIX. Estudios histórico-literarios (2005).

52 María Isabel Sepúlveda Sauras, Tradición y modernidad: Arte en Zaragoza en la década de los años cincuenta (2005).

53 Rosa Tabernero Sala, Nuevas y viejas formas de contar. El discurso narrativo infantil en los umbrales del siglo XXI (2005).

54 Manuel Sánchez Oms, L'Écrevisse écrit: la obra plástica (2006). 
55 Agustín Faro Forteza, Películas de libros (2006).

56 Rosa Tabernero Sala, José D. Dueñas Lorente y José Luis Jiménez Cerezo (coords.), Contar en Aragón. Palabra e imagen en el discurso literario infantil y juvenil (2006).

57 Chantal Cornut-Gentille, El cine británico de la era Thatcher. ¿Cine nacional o "nacionalista"? (2006).

58 Fernando Alvira Banzo, Martín Coronas, pintor (2006).

59 Iván Almeida y Cristina Parodi (eds.), El fragmento infinito. Estudios sobre "Tlön, Uqbar, Orbis Tertius» de J. L. Borges (2007).

60 Pedro Benítez Martín, La formación de un francotirador solitario. Lecturas filosóficas de Louis Althusser (1945-1965) (2007).

61 Juan Manuel Cacho Blecua (coord.), De la literatura caballeresca al Quijote (2007).

62 José Julio Martín Romero, Entre el Renacimiento y el Barroco: Pedro de la Sierra y su obra (2007).

63 M. ${ }^{a}$ del Rosario Álvarez Rubio, Las historias de la literatura española en la Francia del siglo XIX (2007).

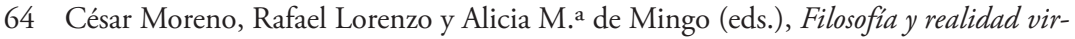
tual (2007).

65 Luis Beltrán Almería y José Luis Rodríguez Garcia (coords.), Simbolismo y hermetismo. Aproximación a la modernidad estética (2008).

66 Juan Antonio Tello, La mirada de Quirón. Literatura, mito y pensamiento en la novela de Félix de Azúa (2008).

67 Manuela Agudo Catalán, El Romanticismo en Aragón (1838-1854). Literatura, prensa y sociedad (2008).

68 Gonzalo Navajas, La utopia en las narrativas contemporáneas (Novela/CinelArquitectura) (2008).

69 Leonardo Romero Tobar (ed.), Literatura y nación. La emergencia de las literaturas nacionales (2008).

70 Mónica Vázquez Astorga, La pintura española en los museos y colecciones de Génova y Liguria (Italia) (2008).

71 Jesús Rubio Jiménez, La fama póstuma de Gustavo Adolfo y Valeriano Bécquer (2009).

72 Aurora González Roldán, La poética del llanto en sor Juana Inés de la Cruz (2009). 
1 titulo Mariposas de Madrid procede de El antimonio, un relato del escritor siciliano Leonardo Sciascia que apareció en la segunda edición de su libro Los tíos de Sicilia, publicada en 1960. El título describe de forma sintética y lírica el cerco de Madrid por los fascistas italianos, entre los que se encuentra el protagonista. El relato está escrito en primera persona: una primera persona del singular que en el pasaje mencionado se convierte en primera persona del plural y que representa a todos los sicilianos en paro que marchan a la guerra para escapar de la pobreza y la miseria. Y no es casual que este soldado carezca de nombre, pues encarna una especie de memoria colectiva que es también la de los escritores, de Vittorini a Sciascia, y, en nuestros días, de Tabucchi a Ramondino: «[...] sentado en la escalinata de la iglesia [...] Era el 15 de agosto de 1937. Dábamos vueltas en torno a Madrid, como las mariposas, de noche, se aproximan a la llama hasta sentir que se queman y amplian el vuelo, de nuevo se aproximan y, por un soplo de viento, la llama les atrapa. Así era Madridy. 